A szalicilsav előkezelés hatása a sóstressz akklimatizációra különös tekintettel a glutation transzferázok szerepére paradicsom és lúdfü növényekben

Doktori (Ph.D.) értekezés

\title{
Horváth Edit
}

Témavezetö:

\section{Dr. Csiszár Jolán}

egyetemi docens

Biológia Doktori Iskola

Növénybiológiai Tanszék

SZTE TTIK

Szeged

2015 


\section{Tartalomjegyzék}

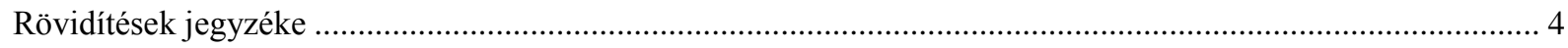

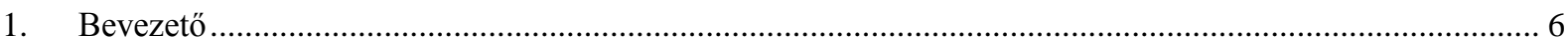

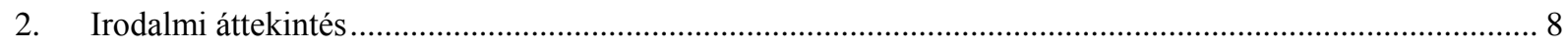

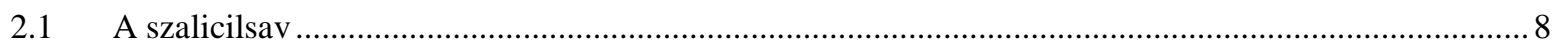

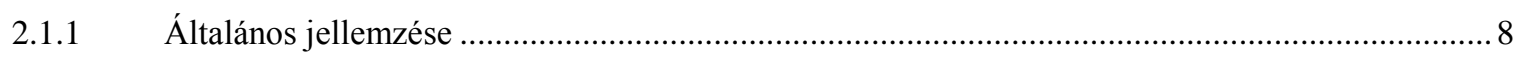

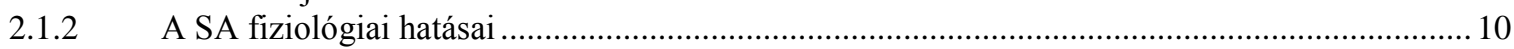

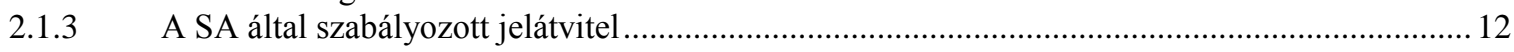

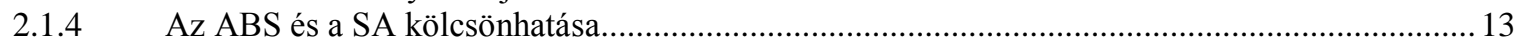

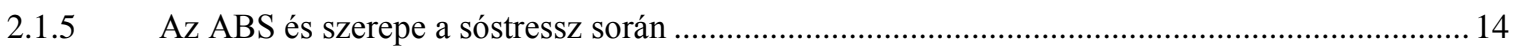

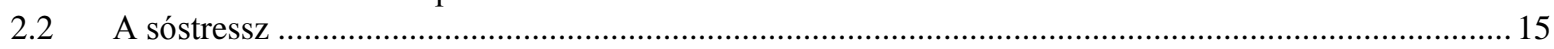

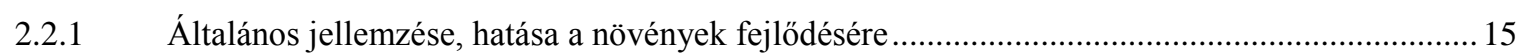

2.2.2 Nem-enzimatikus és enzimatikus antioxidánsok szerepe a sóstressz válaszban ............................ 18

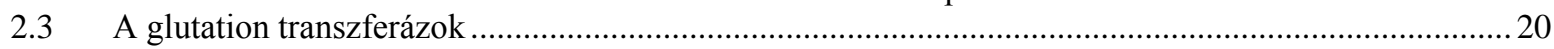

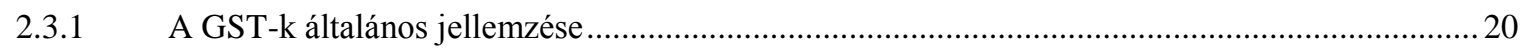

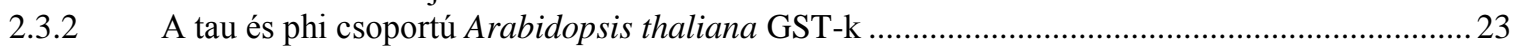

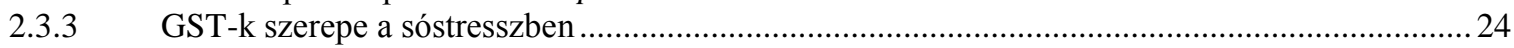

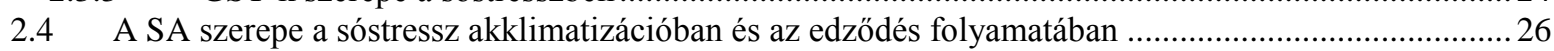

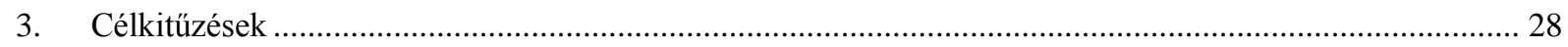

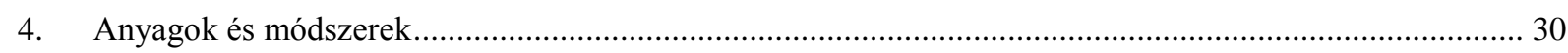

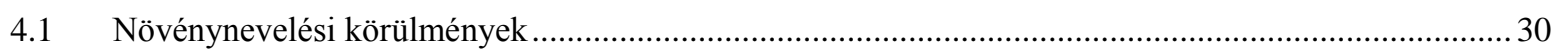

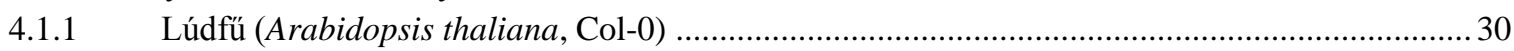

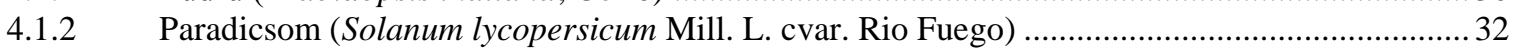

4.2 Elemtartalom meghatározás induktív csatolású plazma tömegspektrométerrel .......................................33

4.3 Életképesség meghatározása és reaktív oxigénformák detektálása fluoreszcens mikroszkóppal ...........33

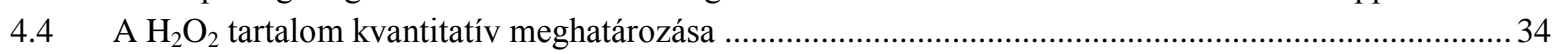

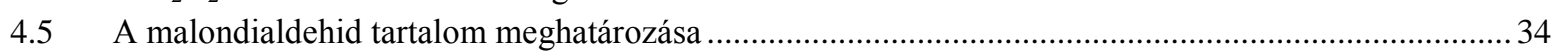

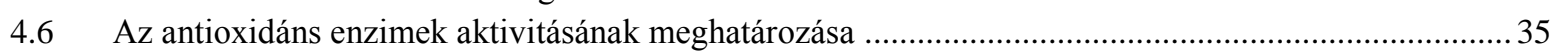

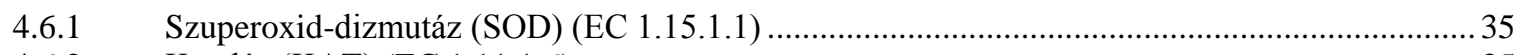

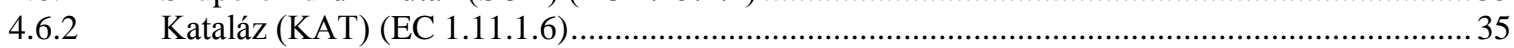

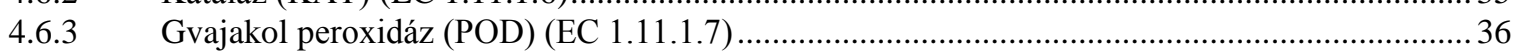

4.6.4 Glutation transzferáz (GST), glutation peroxidáz (GPOX) és dehidroaszkorbát reduktáz

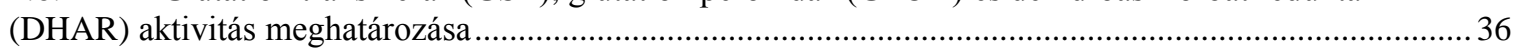

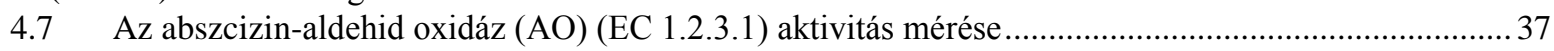

4.8 Szekvencia keresés, filogenetikai és promóter analízis...................................................................... 37

4.9 RNS izolálás, cDNS átírás és QRT-PCR (kvantitatív valós idejű polimeráz láncreakció) ..................... 38

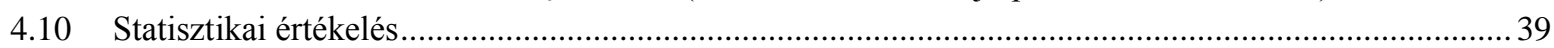

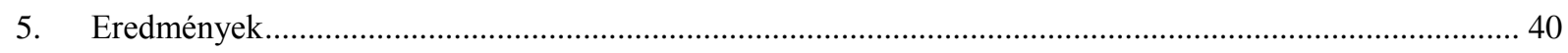

5.1 Lúdfü növények növekedésében bekövetkező változások SA előkezelés és azt követő sóstressz

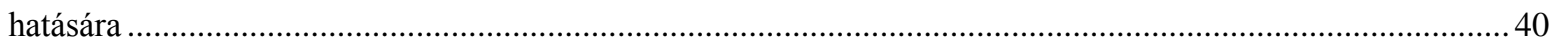

5.2 Elemtartalom változása a SA elökezelést és a sóstresszt követően.....................................................41

5.3 ROS és $\mathrm{H}_{2} \mathrm{O}_{2}$ tartalom SA elökezelt és sóstressznek kitett lúdfü növényekben.....................................43

5.4 A lipidperoxidáció mértékének meghatározása SA előkezelt lúdfü növényekben sóstressz során ......... 44

5.5 Az enzimatikus antioxidánsok aktivitása SA elökezelés és sóstressz alatt ...........................................45

5.6 GST és GPOX aktivitásban bekövetkező változások lúdfü növényekben SA előkezelést követő

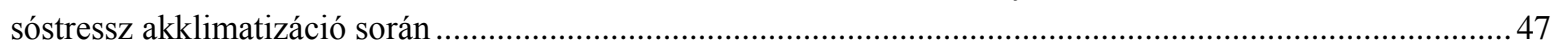

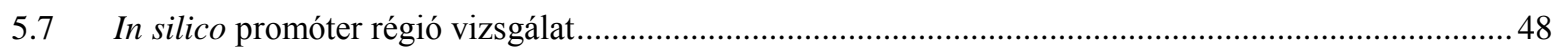

5.8 A kiválasztott $A t G S T$ gének expressziójában bekövetkező változások ............................................... 48 
5.9 GST gének mutációjának hatása a lúdfü csíranövények GST aktivitására, életképességére és gyökérnövekedésére

5.10 Paradicsom növények növekedésében bekövetkező változások SA elökezelés hatására sóstressz akklimatizáció során

5.11 SA előkezelés hatása paradicsom növények $\mathrm{H}_{2} \mathrm{O}_{2}$ tartalmára sóstressz során

5.12 Paradicsom növények levelének és gyökerének GST, GPOX és DHAR aktivitása SA elökezelést követő sóstressz akklimatizáció során

5.13 Paradicsomban található GST gének filogenetikai csoportosítása és génexpressziójuk vizsgálata SA előkezelés és sóstressz során

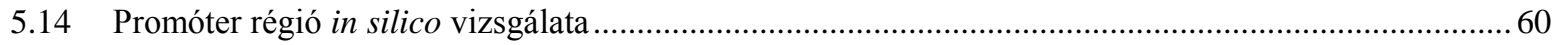

5.15 AO aktivitás SA előkezelt és sóstressznek kitett paradicsom növényekben ....................................60

5.16 ABS bioszintézis gének expressziója SA előkezelés és sóstressz során paradicsom növények levelében

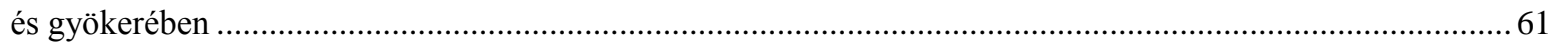

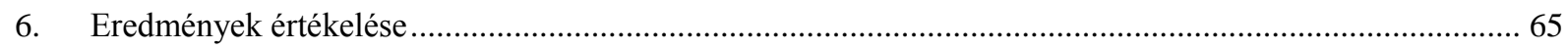

6.1 A hosszútávú SA előkezelés hatása a lúdfü és paradicsom növények sóstressz akklimatizációjára......65

6.2 GST mutáció hatása Arabidopsis thaliana rövidtávú sóstressz válaszára.........................................71

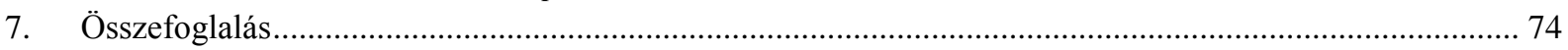

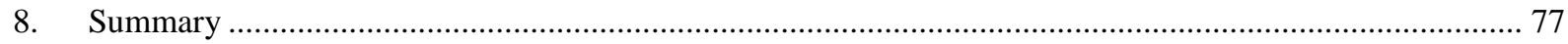

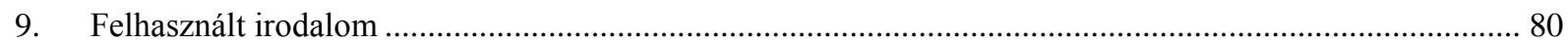

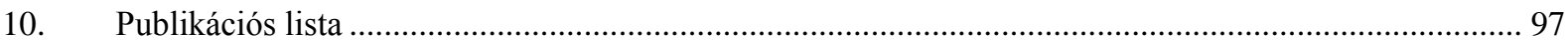

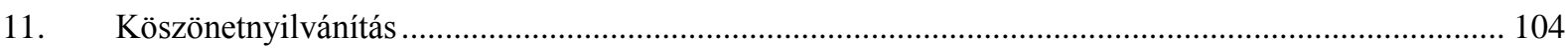

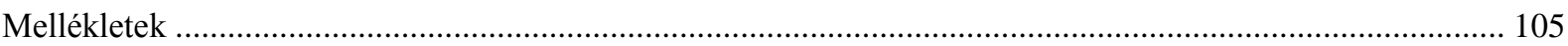




\section{Rövidítések jegyzéke}

\begin{tabular}{|c|c|}
\hline ABAld & abszcizin-aldehid \\
\hline ABS & abszcizinsav \\
\hline $\mathrm{AO}$ & aldehid oxidáz \\
\hline APX & aszkorbát peroxidáz \\
\hline Asc & aszkorbinsav \\
\hline BHT & butilált hidroxitoluol \\
\hline BIT & benzisothiazol-3(2H)-one1,1-dioxide \\
\hline BITC & benzilizotiocianát (benzylisothiocyanate) \\
\hline $\mathrm{CCD}$ & karotinod hasító dioxigenáz (carotenoid cleavage dioxygenase) \\
\hline CDNB & 1-klór-2,4-dinitrobenzol \\
\hline CHP & kumén hidroperoxid \\
\hline DHA & dehidroaszkorbát \\
\hline DHAR & dehidroaszkorbát reduktáz \\
\hline DTT & ditiotreitol \\
\hline FAD & flavin-adenin-dinukleotid \\
\hline FDA & fluoreszcein diacetát \\
\hline FT & friss tömeg \\
\hline GFP & zöld fluoreszcens fehérje (green fluorescent protein) \\
\hline GPOX & glutation peroxidáz \\
\hline GR & glutation reduktáz, GSSG reduktáz \\
\hline GSH & redukált glutation ( $\gamma$-glutamil-ciszteinil-glicin) \\
\hline GSSG & glutation-diszulfid, oxidált glutation \\
\hline GST & glutation transzferáz \\
\hline $\mathrm{H}_{2}$ DCFDA & 2’-7’-diklór-dihidro-fluoreszcein diacetát \\
\hline HR & hiperszenzitív reakció \\
\hline ICP-MS & plazma indukciós tömeg spektrométer \\
\hline KAT & kataláz \\
\hline MAPK & mitogén aktivált protein kináz \\
\hline MDA & malondialdehid \\
\hline MDHA & monodehidroaszkorbát \\
\hline
\end{tabular}


MDHAR monodehidroaszkorbát reduktáz

$\mathrm{MES} / \mathrm{KCl} \quad$ 2-N-morfolin-etánszulfonsav/kálium-klorid

MeSA metil-szalicilát

MS Murashige-Skoog tápsó

MTT 3(4,5-dimetiltiazol-2-il)-2,5-difeniltetrazólium-bromid

NahG bakteriális szalicilát-hidroxilázt kódoló gén

NBT tetrazólium kék (nitroblue tetrazolium chloride)

NCED 9-cisz-epoxikarotin dioxigenáz

NPR1 „non-expressor of pathogenesis-related genes 1”

PMSF fenil-metil-szulfonil-fluorid

POD gvajakol peroxidáz

PR Patogén kapcsolt gének/fehérjék (Pathogene related genes/proteins)

PVPP polivinil-polipirrolidon

QRT-PCR kvantitatív valós idejü polimeráz láncreakció

ROS „reactive oxygen species”, reaktív oxigénformák

SA szalicilsav

SABP Szalicilsav-kötő protein (Salicylic acid-binding protein)

SAR Szisztemikus szerzet rezisztencia (systemic acquired resistance)

SOD szuperoxid dizmutáz

SZT Száraz tömeg

TCA triklórecetsav

TCHQD tetraklórhidrokinon dehalogenáz

ZEP zeaxantin epoxidáz 


\section{Bevezetö}

A növényeket a környezetükben számos stresszhatás érheti, amelyeket biotikus és abiotikus stresszorok idézhetnek elő. A sóstressz egyike a legjelentősebb abiotikus stresszoroknak, amely a növények csaknem minden fiziológiai és biokémiai folyamatára hatással van, csökkenti a növekedést és a terméshozamot, felgyorsult fejlődést, szeneszcenciát és a növény pusztulását okozza. A terméshozam csökkenés visszaszorítására több megoldás is létezik, amelyek egyike a nemesítés során a stressztűrőbb fajtákat szelektálása. Ahhoz, hogy a nemesítés hatékonyabb legyen a növények stressz ellenállóságának jobb megismerése nélkülözhetetlen, az akklimatizációban szerepet játszó folyamatok megértése és a stressztoleranciában fontos gének azonosítása szükséges. A növények stressztürésének javítására a nemesítés mellett más módszereket is keresnek. A szalicilsav (SA) „priming” hatása már több mint 20 éve ismert és exogén alkalmazása ilyen alternatív megoldás lehet. A külsőleg alkalmazott SA sóstresszel szembeni ellenállóságot képes kiváltani, azonban bebizonyosodott, hogy ez a hatás függ a növények fejlödési stádiumától, a kezelés módjától és az alkalmazott koncentrációtól.

Korábbi kísérletek eredményeként a hidropónikus rendszerben alkalmazott SA előkezelés paradicsom növények (Solanum lycopersicum) sóstressz akklimatizációjára gyakorolt pozitív hatása, amelyben az abszcizinsav (ABS) szintjének változása is szerepet játszik, már ismert volt. Ezért paradicsom növényekben megvizsgáltuk az ABS bioszintézishez kapcsolódó gének expresszióját és az egyes enzimek aktivitását. Emellett munkánk során célul tűztük ki a széles koncentráció-tartományban és hosszútávú előkezelésben alkalmazott SA hatásainak vizsgálatát a genetikai modellként széles körben alkalmazott lúdfü (Arabidopsis thaliana) növényeken. A lúdfü modellnövényként lehetőséget kínál a folyamatok hátterének jobb megismeréséhez. Kísérleteinkhez kidolgoztunk egy hidropónikus rendszert és a másodlagosan alkalmazott sóstressz során vizsgáltuk a hosszútávú SA előkezelés hatását lúdfü növények növekedésére, ROS tartalmára és lipidperoxidációjára kifejtett hatását. Összehasonlítottuk az antioxidáns enzimek aktivitásában bekövetkező változásokat az elökezelés és a sóstressz során, a másodlagosan jelentkező oxidatív stressz káros hatásának kivédésében fontos glutation transzferáz (GST) enzimcsalád GST és glutation peroxidáz aktivitását és az egyes AtGST gének expressziójában bekövetkező változásokat. Kiválasztottunk két AtGST mutáns lúdfü vonalat (Atgstf9 és Atgstu19), hogy egyetlen GST gén mutációjának hatását 
tanulmányozzuk rövidtávú SA- vagy $\mathrm{NaCl}$ kezelés hatására. Továbbá paradicsomban is vizsgáltuk a GST aktivitásában és expressziójában megfigyelt változások alapján a GST enzimcsaládot. 


\section{Irodalmi áttekintés}

\subsection{A szalicilsav}

\subsection{1 Általános jellemzése}

A szalicilsav (SA), kémiai nevén $o$-hidroxibenzoesav egy természetesen előforduló fenolos vegyület, amely az egész növényvilágban elterjedt (Raskin 1992). A SA-at ugyan a talajban található mikroorganizmusok is képesek előállítani, de a növényekbe leggyakrabban nem a környezetből kerül, hanem a növényi szövetekben szintetizálódik. Bioszintézise két útvonalon történhet, és mindkét útvonal a korizmátból indul ki (1. ábra). A citoplazmatikus útvonalon a SA korizmisavból L-fenilalaninon keresztül szintetizálódik, míg a kloroplasztiszban végbemenő folyamat során a SA izokorizmáton keresztül, kétlépéses reakcióban alakul ki (Vlot és mtsai. 2009, Rivas-San Vicente és Plasencia 2011).

A különböző növényfajok SA tartalma igen eltérő lehet, akár egy adott családon belül is nagy különbségeket figyelhetünk meg. Például, amíg a Solanaceae családba tartozó dohány alacsony alap SA tartalommal rendelkezik (SA tartalom $<0,1 \mu \mathrm{g} \mathrm{g}^{-1}$ friss tömeg), addig a burgonya $1 \mathrm{~g}$ friss tömegre (FT) vonatkoztatva akár $10 \mu \mathrm{g}$ SA-at is tartalmazhat, a paradicsom pedig 0,15 $\mu$ g-ot. A modellnövényként fontos lúdfü (Arabidopsis thaliana) SA tartalma kontroll körülmények között 0,25 - $1 \mu \mathrm{g} \mathrm{g}^{-1}$ FT (Raskin 1992, Mandal és mtsai. 2009, Hayat és mtsai. 2010; Rivas-San Vicente és Plasencia 2011). Az endogén SA szint jelentősen megnövekedhet fertőzést követően paradicsomban Fusarium oxysporum $f$. sp. lycopersici (Mandal és mtsai. 2009), dohány növényekben pedig dohány mozaik vírus hatására (Enyedi és mtsai. 1992). 


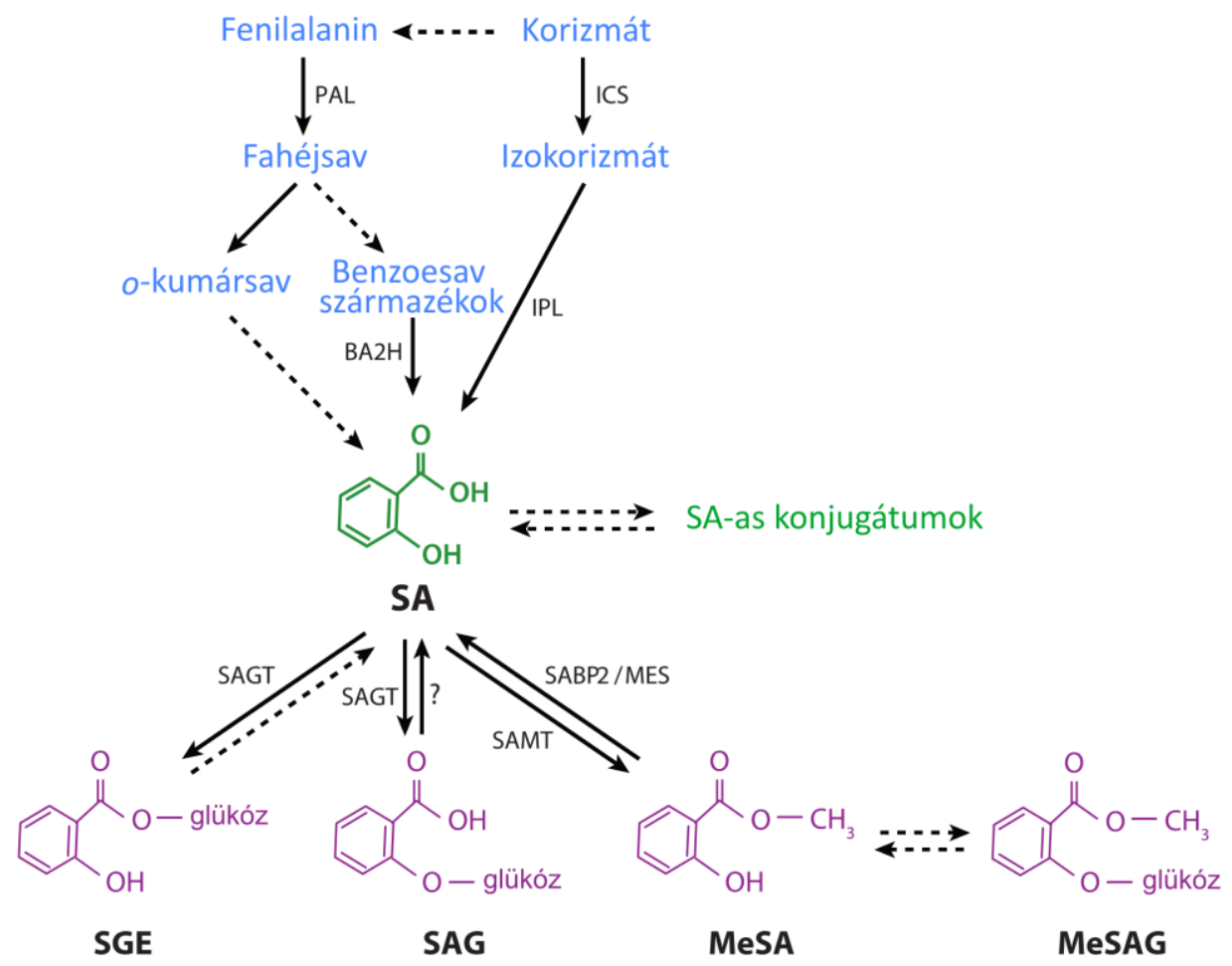

1. ábra: A szalicilsav bioszintézis és metabolizmus sematikus ábrája Vlot és mtsai. (2009) alapján. (as: aminosav, BA2H: benzoesav-2-hidroxiláz, ICS: izokorizmát-szintáz, IPL: izokorizmát-piruvát-liáz, MES: metil-szalicilsav-észteráz, MeSA: metil-szalicilsav, PAL: fenilalanin-ammónia-liáz, MeSAG: metil-szalicilsav $O-\beta$-glükozid, SA: szalicilsav, SABP2: SA-kötö fehérje 2, SAG: szalicilsav $O-\beta$-glükozid, SAGT: szalicilsav-glükozil-transzferáz, SAMT: szalicilsav-metiltranszferáz, SGE: szalicilsav-glükóz-észter)

A SA megemelkedett szintje szorosan összefügg a patogénekkel szembeni ellenállóképesség növekedésével (Raskin 1992, Shirasu és mtsai. 1997, Vlot és mtsai. 2009). Szabályozza az „oxidatív robbanást”, amely a hiperszenzitív reakció (HR) során programozott sejthalálhoz vezet. A fertőzés helyén az ionáramokban és a reaktív oxigénformák (reactive oxygen species, ROS) mennyiségében kialakuló gyors változások jelátviteli kaszkádot indítanak el, aminek során transzkripciós faktorok aktiválásán keresztül indukálódnak a védekezésben fontos gének, köztük a SA szintéziséhez direkt vagy indirekt módon hozzájáruló fehérjék génjei (Dangl és Jones 2001, Métraux 2001, Ashraf és mtsai. 2010). A megemelkedett SA szint, mint fontos jelátviteli molekula a patogének által indukált lokális- és szisztemikus szerzett rezisztenciában (systemic a acquired resistance, SAR) és a környezeti stresszorok elleni védekezésben is szerepet játszik (Shirasu és mtsai. 1997, Hayat és mtsai. 2010). A fertőzött 
szervből a SA képes a floémen keresztül a nem fertőzött szervekbe eljutni (Métraux és mtsai. 1990, Rasmussen és mtsai. 1991). A transzport forma a metil-szalicilát (MeSA), amely egy inaktív prekurzor (Vlot és mtsai. 2009). A SA-at a SA karboxil metiltranszferáz metilálhatja, és az így keletkezett MeSA fontos része a SAR kialakításának (Park és mtsai. 2007). A SA nagyobb része konjugátumként, glükozilált vagy metilált formában található a növényekben. A konjugációs reakcióban leggyakrabban a hidroxil csoport vesz részt és csak ritkább esetben a karboxil csoport (1. ábra). A SA glükoziltranszferáz enzim által a citoplazmában létrehozott SA glükozid a vakuólumba transzportálódik, ahol raktározódhat és szükség esetén visszaalakulhat SA-vá (Dean és Mills 2004).

\subsubsection{A SA fiziológiai hatásai}

A SA hat a növények fejlődésére és más szervezetekkel történő kölcsönhatására (Raskin 1992). Számos fiziológiai és biokémiai folyamatot szabályoz, köztük a magok csírázását, a növekedést és produktivitást, a fotoszintézist, a vízháztartást és a szeneszcenciát (Rivas-San Vicente és Plasencia 2011). Részt vesz a sejt redox állapotának szabályozásában, az antioxidáns enzimek aktivitásának módosításán és az alternatív légzési útvonal indukcióján keresztül (Durner és mtsai. 1997, Slaymaker és mtsai. 2002, Moore és mtsai. 2002).

Megemelkedett endogén SA szinttel rendelkezö lúdfü (Arabidopsis thaliana) mutánsokon végzett vizsgálatokkal bizonyították, hogy a magas SA koncentráció növelheti a növényekben az oxidatív stressz ellen védő enzimatikus és nem-enzimatikus antioxidánsok szintjét, azonban emelheti is a ROS mennyiségét. A SA túltermelő snc1 (suppressor of npr1-1 constitutive 1), lúdfü mutánsok magasabb szuperoxid dizmutáz (SOD) és gvajakol peroxidáz (POD) aktivitás mellett alacsonyabb kataláz (KAT) aktivitással rendelkeztek kontroll körülmények között, és a megemelkedett oxidatív stressz jeleként nőtt a malondialdehid (MDA) szintjük (Hao és mtsai. 2012).

A SA-akkumuláló, állandóan aktivált védekezéssel rendelkező dndl (defence nqo deathl) lúdfü mutánsokban módosult a gének átírása: 49 gén represszálódott és 69, többségében a védekezésben szerepet játszó gén indukálódott a vad típushoz képest. A dndl növényekben az állandóan megemelkedett SA tartalom és az $\mathrm{O}_{3}$ kezelés zavart okozott az apoplasztikus ROS jelátvitelben SA-függő és -független jelátviteli útvonalakon keresztül (Xu és Brosché 2014). 
A szintén magas SA szintet mutató Cvi-0 lúdfü genotípusban a SA oxidatív robbanást és sejthalálhoz vezető útvonalat aktivált (Rao és Davis, 1999). A Cvi-0 genotípus alacsonyabb GSH/GSSG (redukált/oxidált glutation) és Asc/DHA (redukált/oxidált aszkorbát) arányt mutatott a Columbia (Col-0) ökotípussal összevetve és az enzimatikus antioxidánsok (SOD, KAT, POD, aszkorbát peroxidáz - APX és glutation reduktáz - GR) aktivitása is alacsonyabb volt.

Az alacsony SA szinttel rendelkező $N a h G$ (bakteriális szalicilát-hidroxilázt kódoló gén) transzformáns vonalak viszont megemelkedett GSH/GSSG és Asc/DHA aránnyal rendelkeztek (Cao és mtsai. 2008). A lecsökkent SA tartalom a sid2 ( $\underline{S} A$ innduction deficient 2) mutánsokban és a $N a h G$ vonalakban megemelte a POD aktivitását az Arabidopsis magok csírázása során (Lee és mtsai. 2010).

A SA antioxidánsokra gyakorolt hatását külsőleg alkalmazott SA segítségével is sokat vizsgálták, mert az változó lehet, és nagyban befolyásolja az alkalmazott koncentráció és az alkalmazás módja, a növényfaj és a növény fejlődési stádiuma (Horváth és mtsai. 2007, Pál és mtsai 2013). A SA kezelés KAT aktivitást gátló hatásáról többen beszámoltak (Srivastava és Dwivedi 1997, Senaratna és mtsai. 2000, Szepesi és mtsai. 2005, Tasgin és mtsai. 2006), viszont Brassica napus L. növényekben az aktivitása nem változott (Haddadchi és Gerrivani 2009), más tanulmányokban pedig SA kezelés hatására a KAT aktivitás megemelkedését írták le (Agarwal 2005a, Simaei 2011, Ahmad és mtsai. 2012). Paprikában (Capsicum annuum L.) az alacsonyabb koncentrációkban alkalmazott SA csökkentette, a magasabb koncentrációk növelték a KAT aktivitását (Mahdavian és mtsai. 2007). Ezek az eredmények alátámasztják, hogy az egy fajon belüli KAT aktivitás eltérő változását az alkalmazott SA koncentrációja is befolyásolja (Pál és mtsai. 2013, Tari és mtsai. 2015).

A külsőleg alkalmazott SA azonban más enzimek aktivitására is hat, így bizonyos esetekben a SA serkenti a SOD aktivitását, amely hozzájárul a hidrogén peroxid $\left(\mathrm{H}_{2} \mathrm{O}_{2}\right)$ szint emelkedéséhez (Krantev és mtsai. 2008, Sahu és Sabat 2011). A $\mathrm{H}_{2} \mathrm{O}_{2}$ szintjének szabályozásában szerepet játszó másik enzim, a POD aktivitása több esetben megemelkedett külsőleg alkalmazott SA kezelés hatására (Ananieva és mtsai. 2004, Tasgin és mtsai. 2006, Mahdavian és mtsai. 2007, Ahmad és mtsai. 2012), emellett a SA kezelés növelte az APX, GR, monodehidroaszkorbát reduktáz (MDHAR) és dehidroaszkorbát reduktáz (DHAR) enzimek aktivitását (Dat és mtsai. 2000, Yoon és mtsai. 2004, Agarwal és mtsai. 2005a és 2005b, Mahdavian és mtsai. 2007, Krantev 2008). Ugyanakkor az alkalmazott SA 
koncentrációtól függően több tanulmányban számoltak be az antioxidáns enzimek aktivitásának csökkenéséről is (Mahdvian és mtsai 2007, Sahu és Sabat 2011).

\subsubsection{A SA által szabályozott jelátvitel}

A SA receptorának azonosítására irányuló kísérletek eredményeként írták le az első SA-kötő fehérjéket. A SA közvetlenül képes kölcsönhatásba lépni fehérjékkel és gátolni azok

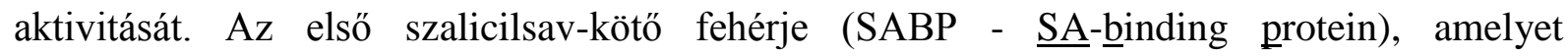
azonosítottak, a kataláz (KAT) volt, amelyről azonban később kiderült, hogy a SA csak bizonyos izoformák aktivitását gátolja (Horváth és mtsai. 2002). Részben ezzel magyarázható a KAT aktivitására gyakorolt változó hatás. A másik SA által gátolt enzim a dohány növényekben azonosított APX, amely szintén a $\mathrm{H}_{2} \mathrm{O}_{2}$ eliminálásában játszik szerepet (Vlot és mtsai. 2009). A legmagasabb SA-kötő affinitással a SABP2 fehérje - a MES - rendelkezik. SA által történő gátlása a fertőzött dohány növény szöveteiben a MeSA felhalmozódását eredményezi, ami a SA nem fertőzött szövetekbe történő transzportját segíti elö (Forouhar és mtsai. 2005, Park és mtsai. 2007). A SABP3 fehérjét, amely a kloroplasztiszban található szénsav-anhidráz, szintén dohány növényekben azonosították (Slaymaker és mtsai. 2002). Lúdfüben újabb fehérjéket azonosítottak SABP-ként: az $\alpha$-ketoglutarát dehidrogenáz E2 alegysége és a glutation transzferázok (GST-k), GSTF2, GSTF8, GSTF10 és GSTF11 is képesek SA-at kötni és a SA-val való kapcsolódásuk gátolja az enzimaktivitásukat (Tian és mtsai. 2012).

A SA jelátviteli útvonalakat tanulmányozva megállapították, hogy az egyik fó útvonal az oligomer NPR1 (non-expressor of pathogenesis-related genes 1) molekulák közötti diszulfid hidak redukciójával kapcsolatos. A keletkező monomerek képesek a sejtmagba transzlokálódni és aktiválni az NPR1-függő védekezési gének átírását (Mou és mtsai. 2003). Emellett a glutation mennyiségének ill. $\mathrm{H}_{2} \mathrm{O}_{2}$-általi oxidáltságának változásai aktiválhatják a SA-függő védekezési géneket NPR1-től függetlenül is (Han és mtsai. 2012). Feltehetően a SA jelátvitelben résztvevő transzkripciós faktorok, mint az NPR1, TGA-doboz és as-1-szerü (ạctivation sequence-1-like) elemek a SA jelátvitel génexpresszió időbeni szabályozásának redox szenzoraiként müködnek, míg az NPR1-független korai SA aktiválta gének termékei antioxidáns és detoxifikáló aktivitással rendelkezhetnek (Blanco és mtsai. 2009). 
Az NPR1-függő útvonal mellett ismert a SA MAP kináz (mitogen activated protein kinase, MAPK) kaszkádon keresztüli jelátvitele is. A MAPK kaszkád, amely az eukriótákban elterjedt rendszer, szerepet játszik a SA és/vagy ROS jelátvitelében és a gének müködésének szabályozásában (Miura és Tada 2014). Lúdfüben a SA jelátvitel pozitív szabályozói az AtMPK3 és AtMPK6, negatív szabályozója pedig az AtMPK4 (Colcombet és Hirt 2008).

A SA jelátvitelben kulcsfontosságú szerepet kapnak a ROS és a $\mathrm{Ca}^{2+}$ (Chen és Kuć 1999, Chen és mtsai. 2001, Kawano és mtsai 2004), emellett a $\mathrm{H}_{2} \mathrm{O}_{2}$, a nitrogén monoxid és a kénhidrogén $\left(\mathrm{H}_{2} \mathrm{~S}\right)$ mint másodlagos jelátvivők szintén részt vehetnek a SA-válasz kialakításában (Gémes és mtsai. 2011, Li és mtsai. 2015).

A SA hat más növényi növekedésszabályozó anyagok, mint az auxinok, a citokininek és az abszcizinsav (ABS) szintjére (Shakirova és mtsai. 2003, Bandurska és Stroiński 2005). A SA akkumuláló sizl (SIZ-type small ubiquitin related modifier (SUMO) E3 ligase) lúdfú mutánsokon végzett kísérletekben a SIZ1-et a sztómazáródás és a szárazságstressz negatív regulátoraként jellemezték (Miura és mtsai. 2013). A SA-válasz negatív szabályozóiként ismertek az ozmotikus- és sóstressz során indukálódó WRKY54 és WRKY70 transzkripciós faktorok. A wrky54wrky70 mutánsok ozmotikus stresszel szembeni magasabb toleranciája a jobb vízmegtartásnak és a megemelkedett sztómazáródásnak volt köszönhető. A WRKY54 és WRKY70 transzkripciós faktorok negatív szabályozói lehetnek a SA bioszintézisének és az ABS szintnek is, és ezáltal indirekt módon a sztómazáródásnak (Li és mtsai. 2013).

\subsubsection{Az ABS és a SA kölcsönhatása}

A SA és az ABS kölcsönösen gátolják egymás bioszintézisét és jelátvitelét (Yasuda és mtsai. 2008). Ismert, hogy a mag fejlődése során szintetizálódó ABS befolyásolhatja a SA lebontását és szintézisét (Kanno és mtsai. 2010), azonban a SA szerepe az ABS szintézisében még nem teljesen tisztázott. Az ABS szintézisben és akkumulációban mutáns lúdfü növény, az aba2-2 SA szintje legalább kétszerese a vad típusúénak, ami az ABS-nak a SA szintézis gátlásában vagy a lebontás serkentésében játszott szerepére utal (Kanno és mtsai. 2010). Ezen kívül a BIT (benzisothiazol-3(2H)-one1,1-dioxide) - egy a SAR-t kiváltó vegyület - által indukált SA akkumulációt megakadályozta a növények ABS-val történő elökezelése. A SAR aktiválása csökkentette az ABS bioszintézis gének expresszióját és a külsőleg alkalmazott ABS gátolta a SA jelátvitelt (Yasuda és mtsai. 2008). 
A SA és az ABS jelátvitelében emellett pozitív visszacsatolást is megfigyeltek. A SA bioszintézis mutáns sid2 lúdfü növényekben biotikus stressz során megfigyelhető az ABS szintjének csökkenése, ami a SA-nak az ABS akkumulációjának indukciójában betöltött szerepére utal (de Torres Zabala és mtsai. 2009). Emellett a SID2 expressziója ABS jelenlétében megemelkedett lúdfü levelében (Seo és Park 2010). Ez alapján feltételezhető, hogy az ABS fejlődési stádiumtól függő- és szövetspecifikus módon indukálja a SA bioszintézisét. Ezek az eredmények arra utalnak, hogy a két növekedésszabályozó anyag egymás szintjét kölcsönösen képes növelni is.

\subsubsection{Az ABS és szerepe a sóstressz során}

Az ABS számos fejlődési és stressz folyamatban részt vesz (Guóth és mtsai. 2010). Az ABS bioszintézise szárazságstressz során először a gyökérben emelkedik meg, majd a xilémen keresztül transzportálódik a hajtásba, és mint hosszútávú kémiai jel működik (Davies és mtsai. 2005, Wilkinson és Davies 2002 és 2010).

Az ABS bioszintézise a C40-es karotinoidokból indul ki és pozitív visszacsatolással a saját bioszintézisét szabályozza (Xiong és Zhu 2003). Az első, kloroplasztiszban lejátszódó reakciót a zeaxantin epoxidáz (ZEP) enzim katalizálja, ami a zeaxantint all-transzviolaxantinná alakítja át (Seo és Koshiba 2002). A sebességmeghatározó lépést, a violaxantin és neoxantin xantoxinná alakítását, a 9-cisz-epoxikarotinoid dioxigenáz (NCED) végzi (Thompson és mtsai. 2000, Ahrazem és mtsai. 2012). Az ezt követő lépések a citoszolban játszódnak le, ahol a xantoxin először abszcizin-aldehiddé (ABAld) alakul át, majd az ABAld-et az aldehid oxidázok (AO-k) ABS-vá alakítják (González-Guzman és mtsai. 2002, Schwatz és Zeevaart 2010). A molibdén hidroxilázok csoportjába tartozó AO-k széles szubsztrátspecifitással rendelkeznek, számos aldehid és aromás heterociklikus vegyület oxidatív hidroxilációját katalizálják. Az ABS ezen kívül ABAld-ből abszcizin-alkoholon keresztül is kialakulhat és a folyamathoz nem szükséges aktív aldehid oxidáz enzim (Cowan 2000).

Az NCED-szabályozta reakció, a neoxantin oxidatív hasítása sebességmeghatározó a levelekben, a nem fotoszintetikus szövetekben viszont, mint a magok és a gyökér, a ZEP szabályozhatja az ABS szintézisét (Xiong és Zhu 2003). Vízhiány és magas sókoncentráció 
hatására megemelkedik a ZEP és az NCED expressziója (Iuchi és mtsai. 2000, Mulholland és mtsai. 2003, Gallé és mtsai. 2013).

Barrero és mtsai. (2006) kimutatták ABS hiányos lúdfü mutánsokban, hogy ABS-fügő ABS bioszintézis szabályozásán kívül ABS-független utak is léteznek növényekben. Megerősítették, hogy az NCED3 reagál leginkább a 300 mM NaCl kezelésre az ABS-hiányos aba1-101, aba2-14, aba3-101 és aao3-2 mutáns vonalakban, így a magas sókoncentráció indukálhatja az $A B A 1, N C E D 3$ és $A A O 3$ géneket lúdfüben $\mathrm{ABS}$ független úton is.

Az ABAld ABS-vá történő oxidációja egy másik lehetséges szabályozó pont az ABS szintézisében. A három ismert borsó (Pisum sativum) AO eltérő expressziós mintázatot mutatott ammónium- és só kezelés alatt fiatal, kifejlett és öregedő levelekben (Zdunek-

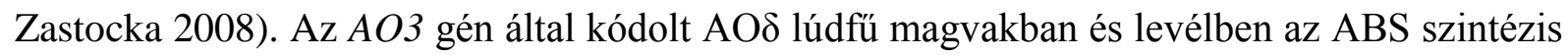
utolsó lépéséért felelős (Seo és mtsai. 2000, 2004). Az eddig jellemzett AO-ok közül lúdfüben az AO3 (Seo és mtsai. 2000), árpa gyökerében pedig az AO2 és AO3 (Omarov és mtsai. 2003) használnak hatékonyan ABAld-et szubsztrátként. Paradicsomban három AO gént (TAO1, TAO2 és TAO3) és 2 AO szekvenciát (TAO4 és TAO5) írtak le (Ori és mtsai. 1997). Ezek az AO gének mind a hajtásban mind a gyökérben kifejeződnek, de szerepük a fiziológiai folyamatokban eltérő lehet a növényekben (Min és mtsai. 2000). Az AO-k szerepét a sóstressz során több tanulmányban is leírták. Dohány kalluszokban $100 \mathrm{mM} \mathrm{NaCl}$ megemelte az AO1 aktivitását és új izoenzim (AO2) megjelenését eredményezte (Csiszár és mtsai 2007). A dohány növényhez hasonlóan borsóban is kimutatták 50 és $100 \mathrm{mM} \mathrm{NaCl} \mathrm{kezelés} \mathrm{során} \mathrm{az}$ AO aktivitás emelkedését (Zdunek és Lips 2001).

\subsection{A sóstressz}

\subsection{1 Általános jellemzése, hatása a növények fejlődésére}

Sóstresszről akkor beszélünk, amikor a talajoldatok sókoncentrációja meghaladja a növények számára optimális koncentrációtartományt. Sóstressz alatt leggyakrabban $\mathrm{NaCl}$ felhalmozódást értünk, amely visszafordíthatatlan károsodást okoz a terméshozamban, ezért fontos a növények sóstressz során fellépő védekezési folyamatainak megértése. A megemelkedett sókoncentráció összetett módon befolyásolja a növények növekedését és 
fejlődését. Elsősorban csökkenti a talaj vízpotenciálját és ozmotikus stresszt okoz, másrészről a $\mathrm{Na}^{+}$és $\mathrm{Cl}^{-}$ionok többletben történő felvétele ionos stresszhez vezet

A sóstressz ionegyensúlyra gyakorolt hatása is többrétü és a tápanyagelemek egyensúlyának felborítása mellett másodlagosan oxidatív stresszt is okoz (Zhu 2001, 2003, Munns 2005). A $\mathrm{Na}^{+}$ionok a nemszelektív kation csatornákon keresztül (NSCC, non-selective cation channel) bejutnak a sejtbe és ezáltal depolarizálják a membránt, aminek következtében nagymértékü $\mathrm{K}^{+}$kiáramlás jelentkezik a depolarizáció-aktivált kifelé rektifikáló $\mathrm{K}^{+}(\mathrm{KOR}$, depolarizationactivated outward-rectifying $\mathrm{K}^{+}$channel) csatornákon keresztül. Ezzel egyidőben a sóstressz a $\mathrm{Ca}^{2+}$ citoplazmában való akkumulációján, ezáltal a $\mathrm{Ca}^{2+}$ koncentráció megemelkedésén keresztül aktiválja a NADPH oxidázt, ami a ROS szint növekedéséhez vezet. Az így megemelkedett ROS további $\mathrm{K}^{+}$effluxot idéz elö ROS-aktiválható NSCC csatornákon keresztül (Shabala 2009). A Na ${ }^{+}$felhalmozódása a növényi sejtek citoplazmájában toxikus hatású, a fehérjék dehidratálódásához vezet, amelyek így elvesztik natív konformációjukat. $\mathrm{Az}$ abnormális $\mathrm{K}^{+} / \mathrm{Na}^{+}$arány enzimeket inaktiválhat és gátolja a fehérjeszintézist éppen ezért megfelelő arányuk elengedhetetlen a növények túlélése szempontjából (Shabala 2009).

A megnövekedett külső sókoncentráció másik hatása az ozmotikus stressz (Munns és Tester 2008). Az ozmotikus egyensúly szabályozása ezért rendkívül fontos a növények vízháztartásának fenntartásában (Zhao és mtsai. 2009). Az ozmotikus homeosztázis megőrzése történhet szervetlen ozmotikumok (pl. $\mathrm{K}^{+}$) koncentrálódásával, azonban még fontosabb lehet az ún. kompatibilis ozmotikumok szintézise, amelyek olyan szerves oldott anyagokat jelentenek mint pl. a cukrok, a prolin vagy a glicinbetain. A kompatibilis ozmotikumok közös jellemzője, hogy magas koncentrációban sem zavarják meg a sejtek biokémiai folyamatait és biztosítják az enzimek aktivitását is sóstressz során (Zhao és mtsai. 2009).

A sóstressz harmadik hatása az oxidatív stressz, amit a fokozott ROS produkció okoz (Miller és mtsai. 2010). Sóstressz során megemelkedik az olyan reaktív oxigénformák szintje, mint a szuperoxid gyökanion $\left(\mathrm{O}_{2}{ }^{-}\right)$, a $\mathrm{H}_{2} \mathrm{O}_{2}$ és a hidroxilgyök $\left(\mathrm{OH}^{*}\right)$, amely magas koncentrációban a sejtek számára végzetes lehet mivel a membránlipidekben, proteinekben és nukleinsavakban oxidatív károsodást okoznak és a redox homeosztázist megváltoztatják (Hasegawa és mtsai. 2000, Foyer és Noctor 2009). A megemelkedett ROS szintet okozhatja a fotoszintetikus elektron transzportlánc megszakítása, a peroxiszómákban termelődő $\mathrm{H}_{2} \mathrm{O}_{2}$, a megemelkedett 
respiráció, a plazmamembrán-kapcsolt NADPH-oxidáz és az apoplasztikus diamin oxidáz aktiválása (Munns és Tester 2008, Abogadallah 2010).

A növények összetett, a só-válaszra jellemző jelátvitelt és metabolikus folyamatokat alakítottak ki sejt-, szerv- és egyed szintjén, hogy a sóstresszel szemben eredményesen védekezzenek. Zhang és mtsai. (2012) 34 növényfajon végzett proteomikai vizsgálat adatai alapján arra a következtetésre jutottak, hogy a sóstressz válaszban résztvevő proteinek többsége (1501), indukciót mutat és csak kisebb számú protein (856) kifejeződése csökken. Ezért általánosságban elmondható, hogy a sóstressz válasz ill. a sótolerancia kialakulására nagyobb mértékben jellemző a megemelkedett fehérje kifejeződés és anyagcsere aktivitás (Zhang és mtsai. 2012). Glikofita és halofita növényeket összehasonlítva azt is megállapították, hogy a sóstressz válasz során a halofiták olyan specifikus anyagcserével rendelkeznek, amely hatékonyabbá teszi a fotoszintézisüket és energia metabolizmusukat, a ROS eliminálását, az ion homeosztázis fenntartását valamint a kompatibilis ozmotikumok termelését, az antioxidáns enzimek és hormonok indukcióját és a sejtstruktúra módosítását (Zhang és mtsai. 2012) (2. ábra).

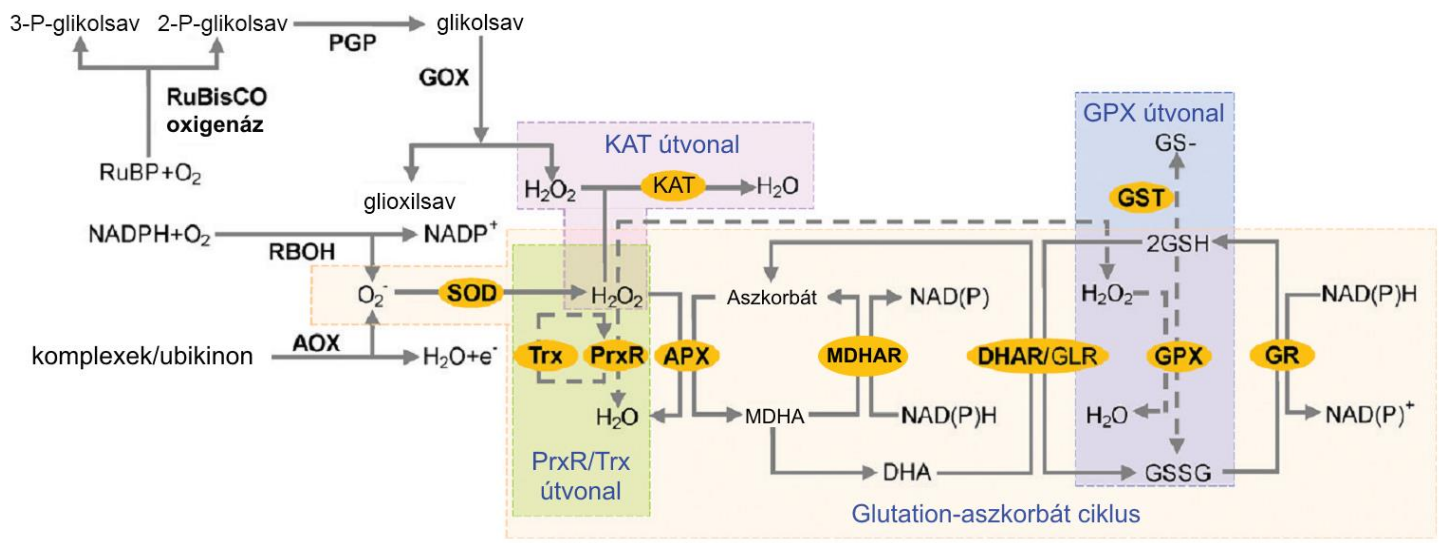

2. ábra: A sóstressz válaszban résztvevő fehérjék és enzimek a növények ROS kioltó rendszerében (Zhang és mtsai. 2012). 2-P-glikolsav: 2-foszfoglikolsav; 3-P-glikolsav: 3foszfoglikolsav; AOX: alternatív oxidáz; APX: aszkorbát peroxidáz; KAT: kataláz; DHA: dehidroaszkorbát; DHAR: dehidroaszkorbát reduktáz; GLR: glutaredoxin; GOX: glikolsav oxidáz; GPX: glutation peroxidáz; GR: glutation reduktáz; GSH: redukált glutation; GSSG: oxidált glutation; GST: glutation transzferáz; MDHA: monodehidroaszkorbát; MDHAR: monodehidroaszkorbát reduktáz; $\mathrm{NAD}^{+} / \mathrm{NADH}$ : nikotinamid-adenin-dinukleotid; $\mathrm{NADP}^{+} / \mathrm{NADPH}$ : nikotinamid-adenin-dinukleotid foszfát; PGP: foszfoglikolát foszfatáz; PrxR: peroxiredoxin; RBOH: NADPH oxidáz; RuBisCO: ribulóz-1,5-biszfoszfát karboxiláz/oxigenáz; RuBP: ribulóz-1,5-biszfoszfát; SOD: szuperoxid dizmutáz; Trx: tioredoxin. 
A sótolerancia tehát komplex jelenség, számos géncsalád együttes müködését foglalja magába, amelyek termékei különböző funkciókat látnak el (Abogadallah 2010). Ezek közé tartoznak a sztómákon keresztüli vízvesztés szabályozása, az ionok kizárása, az anyagcsere és az ozmotikumok, valamint az antioxidáns mechanizmusok aktiválása (Zhu 2001, Parida és Das 2005, Miller és mtsai. 2010).

A többlet ROS elleni védekezés elsődleges elemei a nem-enzimatikus antioxidánsok (aszkorbát, glutation, karotinoidok, tokoferolok) és az antioxidáns enzimek, amelyek szerepet játszanak a ROS eliminálásában (SOD, KAT, POD, APX) és a sejt redox állapotának fenntartásában (pl. GR, DHAR, MDHAR). A megemelkedett antioxidáns kapacitás gyakran a magasabb stressz - köztük a sóstressz - tolerancia jele (Joseph és Jini 2011), azonban a ROS a különböző stresszorok elleni válasz jelátvitelében is fontos szerepet tölthet be. A ROS-ok jelentőségét különböző stresszhatások elleni tolerancia növelésében, és a rezisztencia kialakításában már többen leírták (Dat és mtsai. 2000, Mittler és mtsai. 2004, Van Breusegem és mtsai. 2008, Jaspers és Kangasjarvi 2010). A magas antioxidáns enzimaktivitást megfigyelték a sótolerancia és a sóstresszel szembeni érzékenység kapcsán egyaránt (Abogadallah 2010).

\subsubsection{Nem-enzimatikus és enzimatikus antioxidánsok szerepe a sóstressz válaszban}

A növények egyik fő nem-enzimatikus antioxidánsa az aszkorbinsav, amely semlegesíti a reaktív oxigénformákat és ezáltal hozzájárul a fotoszintetikus funkciók fenntartásához. Az aszkorbinsav többnyire redukált formában (Asc) van jelen a sejtekben, és oxidált formájának (DHA) megemelkedett szintje a stressz tünete lehet. Az aszkorbinsav alapvető feladata a növények védekezésében az anyagcsere folyamatok védelme a megemelkedett $\mathrm{H}_{2} \mathrm{O}_{2}$ szinttel és más oxigén származékokkal, mint pl. a ${ }^{1} \mathrm{O}_{2}, \mathrm{O}_{2}{ }^{-}$és $\mathrm{OH}^{\bullet}$ szemben (2. ábra2. ábra). Emellett képes a tokoferolt regenerálni, így biztosítva a membránok védelmét. $\mathrm{A}_{2} \mathrm{O}_{2}$ átalakításában fontos szerepet játszik az APX, ami két aszkorbát molekula felhasználásával alakítja vízzé a $\mathrm{H}_{2} \mathrm{O}_{2}$-ot miközben monodehidroaszkorbátot (MDHA) képez az Asc-ból (Foyer és Noctor 2009). Az MDHA két módon redukálódhat, spontán módon DHA-tá és Asc-tá alakulhat vagy a MDHAR alakítja át Asc-tá (2. ábra). Vital és mtsai. (2008) kimutatták, hogy az APX aktivitása 2 óra $\mathrm{NaCl}$ és parakvát kezelés hatására megemelkedett gyapot kalluszokban. $\mathrm{Az}$ OsAPXa vagy OsAPXb szekvenciákat túltermelö, transzgenikus Arabidopsis növények pedig megemelkedett sóstressz toleranciát mutattak ( $\mathrm{Lu}$ és mtsai. 2007). Az Arabidopsis 
AtMDHARl gén túltermeltetése dohány növényekben növelte az ózonnal, sóval és polietilén glikollal szembeni toleranciát. A magasabb toleranciát a megemelkedett MDHAR aktivitás következtében akkumulálódó Asc eredményezhette (Eltayeb és mtsai. 2007).

A DHA redukálásáért felelős enzim a DHAR az Asc regenerálása során elektrondonorként redukált glutationt (GSH) használ, ilyen módon összekapcsolja az aszkorbát-glutation ciklust. A GSH egy tripeptid, ami a legtöbb növényi sejtben a legföbb, nem protein eredetü tiol csoport forrása. A GSH az Asc-hoz hasonlóan nagyobb mennyiségben fordul elő redukált állapotában normál körülmények között. Antioxidáns hatását több módon fejtheti ki. A GSH magas redukciós potenciállal rendelkezik a cisztein csoportnak köszönhetően, így képes a $\mathrm{H}_{2} \mathrm{O}_{2}$ csapdázására és más ROS, mint a $\mathrm{O}_{2}{ }^{--}$és $\mathrm{OH}^{*}$, nem-enzimatikus reakción keresztüli kioltására (Noctor és mtsai. 2011). Másik antioxidáns mechanizmus során enzimatikus úton regenerálja a DHA-ot (aszkorbát-glutation ciklus). Emellett nem-enzimatikus úton is képes a DHA redukciójára, miközben oxidálódik és oxidált glutation keletkezik (GSSG). A keletkező GSSG-t a GR enzim alakítja újra GSH-ná. A GR katalizálja az aszkorbát-glutation ciklus utolsó, egyben sebesség-meghatározó lépését, ami szerepet játszik a magas GSH/GSSG arány fenntartásában és ez által hozzájárul az aszkorbát regenerálásához (Noctor és mtsai. 2002). A GR enzim aktivitása sóstressz során megemelkedett gyapot kalluszokban (Vital és mtsai. 2008), emellett só szenzitív kukoricában a sókoncentráció növekedésével és Plantago-ban só kezelés hatására a GR aktivitás csökkenését írták le (de Azevedo Neto és mtsai 2006, Sekmen és mtsai. 2007).

Számos sószenzitív és sótoleráns genotípus összehasonlító vizsgálata kapcsolta a sótoleranciát a megemelkedett antioxidáns enzimaktivitáshoz (Shalata és mtsai. 2001, Mittova és mtsai. 2002, Sumithra és mtsai. 2006, Sekmen és mtsai. 2007). Amíg néhány tanulmányban egyes antioxidánsok túltermeltetése javította a sótoleranciát (Eltayeb 2007, Prashant 2008), más tanulmányok nem találtak egyértelmü összefüggést a sótolerancia és a megemelkedett antioxidáns aktivitás között (Kim 2004). A felmerülő ellentmondások arra vezethetők vissza, hogy a növények sótoleranciájának különbözősége nem csak ROS-t kioltó képességükben keresendők. A $\mathrm{H}_{2} \mathrm{O}_{2}$-detoxifikáló enzimek feladata sokkal inkább az, hogy kontrollálják a $\mathrm{H}_{2} \mathrm{O}_{2}$ sejten belüli koncentrációját és nem pedig a teljes eltávolítása (Abogadallah 2010).

Az egyes enzimek funkciója is különbözhet. A KAT a POD-nál kisebb affinitással rendelkezik $\mathrm{H}_{2} \mathrm{O}_{2}$-vel szemben, így a KAT vélhetően a nagy koncentrációban keletkezett, 
többlet $\mathrm{H}_{2} \mathrm{O}_{2}$ eltávolításában, a POD viszont a $\mathrm{H}_{2} \mathrm{O}_{2}$ szintjének finom szabályozásában vehet részt (Willekens és mtsai 1997, Noctor és Foyer 1998, Mittler 2002).

Más általános és specifikus szereppel rendelkező fehérjék, mint a GST-k is szerepet játszanak a sóstresssz során másodlagosan jelentkező oxidatív stressz hatására képződő citotoxikus anyagok, köztük a lipid peroxidok eliminálásában (Mittler 2002, Jaleel és mtsai. 2009, Potters és mtsai. 2010). A GST-k szerepét a sóstressz válaszban cDNS és protein szinten is leírták (Seki és mtsai. 2002, Ndimba és mtsai. 2005).

\subsection{A glutation transzferázok}

\subsubsection{A GST-k általános jellemzése}

A GST-k az élővilágban széleskörüen elterjedt enzimek, megtalálhatóak a baktériumokban, gombákban, rovarokban, emlősökben és a magasabb rendü növényekben egyaránt (Droog 1997). A növényi GST-k diverz, számos funkcióval rendelkező enzimcsoportot alkotnak, amelyek katalitikus reakcióik során szubsztrátként GSH-t ( $\gamma$-Glu-Cys-Gly) használnak.

A GST-ket 7 szolubilis (phi- GSTF, lambda- GSTL, tau- GSTU, théta- GSTT, zéta- GSTZ, dehidroaszkorbátreduktáz- DHAR és a tetraklórhidrokinon dehalogenáz- TCHQD) és egy membránhoz kötött (mikroszómális) csoportba sorolták (Edwards és Dixon 2005). Újabban szerkezeti hasonlóságuk miatt az eukarióta transzlációs elongációs faktor 1B $\gamma$-alegységét is a növényi GST-k családjába sorolják (Lan és mtsai. 2009, Liu és mtsai 2013).

A GST-k egy, az N-terminális végen lévő GSH-kötő doménnel („G-site”) (Edwards és mtsai. 2000) és egy alfa helikális szerkezetü, C-terminálison található szubsztrátkötő hellyel („,Hsite”) rendelkeznek. A két domén között található variábilis összekötő régió 5-10 aminosavból áll (Dixon és mtsai. 2002a). A „H-site” hidrofób természetű és a szubsztrátok és ligandok változatos csoportját képes kötni (Dixon és Edwards 2010). A GST-k molekulatömege 25-27 kDa, leggyakrabban homo- és heterodimer formában aktívak. Ez alól kivételt képeznek a lambda és a DHAR csoportok tagjai, amelyek monomer formában aktívak, emellett a katalitikus helyükön szerin helyett ciszteint tartalmaznak (Edwards és Dixon 2005).

A GST-k szerepét a sejtre káros vegyületek detoxifikálásában és a szövetek oxidatív károsodás elleni védelmében, valamint a másodlagos anyagcseretermékek, pl. a flavonoid 
származékok, metabolizmusában és biokémiai reakcióiban már több évtizede leírták (Marrs 1996, Droog 1997). GST-túltermelő transzgenikus növényekben szignifikáns oxidatív stressztolerancia növekedést mutattak ki (Roxas és mtsai. 2000, Zhao és Zhang 2006, Ji és mtsai. 2010). A GST-k enzimatikus reakcióik mellett nem-enzimatikus, szállító fehérje funkciót is betöltenek és közremüködnek az antociánok vakuólumba történő transzportjában (Kitamura és mtsai. 2004). A GST-k rendelkeznek egy harmadik kötőhellyel is („L-site”), ami a nem-szubsztrát ligandok kötőhelyéül szolgál. A GST-k ezen funkciójuk révén részt vehetnek hormonok (auxinok, citokinin, gibberellinek) sejten belüli raktározásában és transzportjában (Marrs 1996). Így egyes GST-k fontos szerepet töltenek be a hormonok metabolizmusában vagy hatásában és szabályozó szerepük van a növekedésben és fejlődésben. Számos növényi hormon, köztük az auxin, etilén, abszcizinsav, jázmonsav és szalicilsav indukálhatja őket (Cummins és mtsai. 1999, Edwards és mtsai. 2000, Kilili és mtsai. 2004). Szerepük lehet a programozott sejthalál szabályozásában is. Kampranis és mtsai. (2000) az emlős pro-apoptotikus Bax protein alkalmazásával azonosítottak paradicsomban egy tau csoportba tartozó GST-t a Bax-indukálta sejthalál kivédésében szerepet játszó gének között. Ez a „Bax-inhibitor GST” (BI-GST, SIGSTU24) GSH-konjugáló és glutation peroxidáz aktivitást mutatott. Kimutatták továbbá, hogy az élesztőben történő expressziója megemelte a $\mathrm{H}_{2} \mathrm{O}_{2}$-indukált stressz rezisztenciát, helyreállította a mitokondriális membrán potenciált és a GSH mennyiséget normál szintre állította vissza. További 5 paradicsom GSTU (LeGSTU1-5) fehérjét azonosítottak, amelyek a BI-GST-vel heterodimereket alkottak és ezek a fehérjék képesek voltak kivédeni a pro-oxidánsok indukálta sejthalált élesztő sejtekben (Kilili és mtsai. 2004).

A GST-ket leginkább a genetikai modellnövényként jól ismert lúdfüben jellemezték. Lúdfüben 57 GST szekvencia ismert, amelyet 9, különböző számú taggal rendelkező csoportra oszthatunk. A 3. ábra mutatja a 28 GSTU, 13 GSTF, 3 GSTT, 2 GSTZ, 3 GSTL, 4 DHAR, 2 eukarióta elongációs faktor 1B $\gamma$ alegységeket és egy TCHQD szekvencia felhasználásával készült filogenetikai törzsfát. A törzsfa nem tartalmazza a mikroszómális GST-t.

A zöld fluoreszcens fehérje (GFP, green fluorescent protein) GST szekvenciához kapcsolásával végzett széleskörü lokalizációs vizsgálatokból kiderült, hogy a théta csoport minden tagja a peroxiszómában lokalizálódik (Dixon és mtsai. 2009). A vizsgált phi (F2, F6, F8, F9 és F12) és tau csoportba tartozó (U2, U7, U9, U11, U19 és U28) fehérjék nagy része a 
citoplazmában lokalizálódott, azonban a GFP-GSTF2 és a GFP-GSTU19 ko-lokalizációt mutatott a sejtmaggal, a GFP-GSTU12 pedig csak a sejtmagban adott jelet. Továbbá a nagyon egyedi szekvencia-motívumokat tartalmazó GSTL2 a citoszolban és a peroxiszómában is megtalálható volt, míg a TCHQD a plazmamembránban lokalizálódott (Dixon és mtsai. 2009).

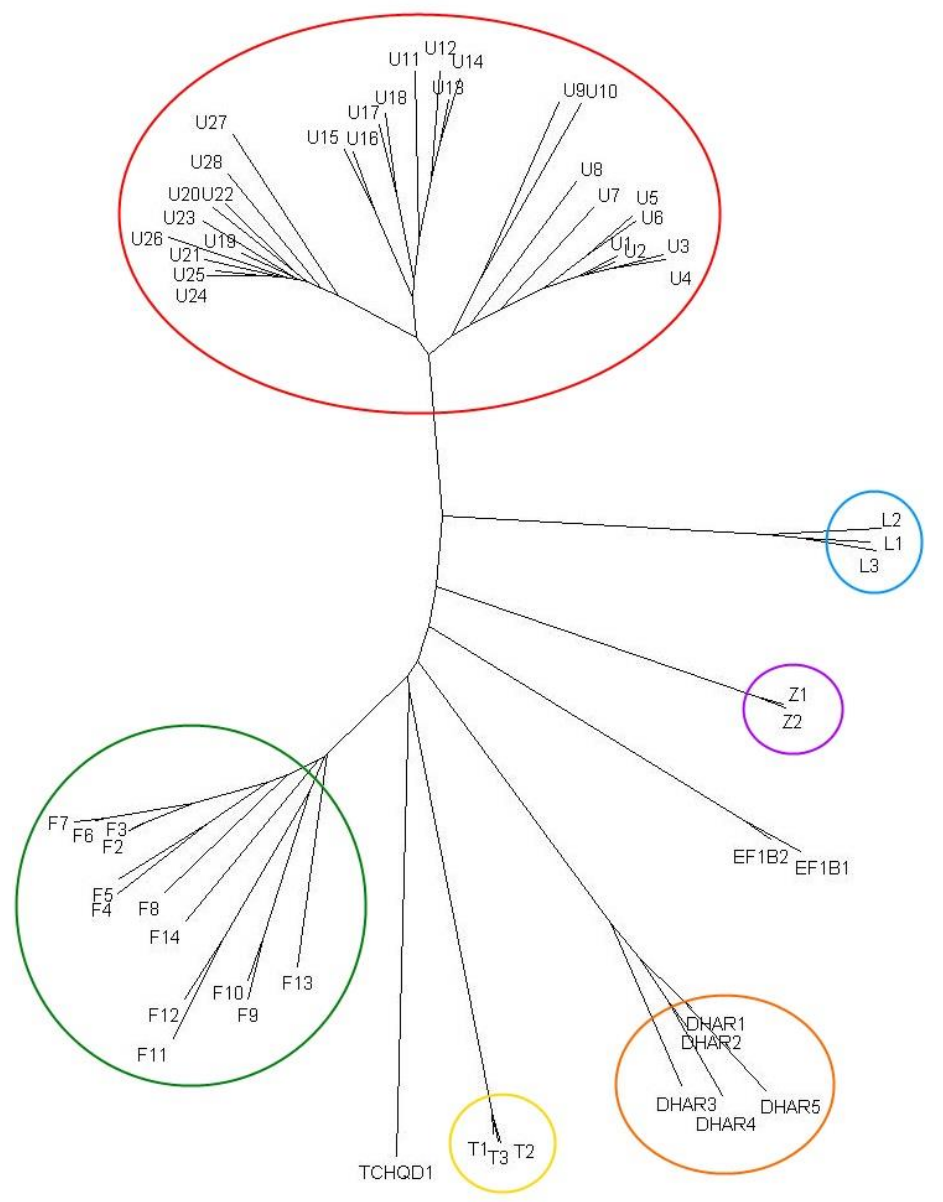

3. ábra: Lúdfü GST-k filogenetikai törzsfája. A különböző csoportokat a következőképpen jelöltük: tau - U; phi - F; tetraklórhidrokinon dehalogenáz - TCHQD; théta $-\mathrm{T}$; dehidroszkorbátreduktáz - DHAR; elongációs faktor 1B $\gamma$-alegysége - EF1B; zéta - Z; lambda - L.

A GST-k szubsztrát specifitását a mérések során leggyakrabban használt xenobiotikummal, a 1-klór-2,4-dinitrobenzollal (CDNB) vizsgálva megállapították, hogy ezt a szubsztrátot alkalmazva a legtöbb GST rendelkezik GSH-konjugáló aktivitással (Dixon és mtsai. 2009). A théta csoportba tartozó GST-k kumén hidroperoxiddal (CHP) és zsírsav hidroperoxidokkal 
szemben is magas GSH-függő peroxidáz aktivitással rendelkeznek és in vivo az oxidatív stressz során keletkezett szerves hidroperoxidok redukcióját végzik (Dixon és mtsai. 1998). A zéta csoportú GST-k GSH függő izomerázok, szerepet játszanak a tirozin degradációban, ahol GSH-függő módon a maleilacetecetsav fumarilacetáttá történő átalakítását végzik (Basantani és Sirvastava 2007). A DHAR és a lambda csoportba tartozó GST-k tiol transzferázok vagy oxidoreduktázok. Amíg a DHAR izoenzimek a dehidroaszkorbát redukcióját katalizálják, addig a lambda csoportba tartozó GST-k kis molekulák, pl. S-glutationált fenolos vegyületek redukcióját végzik (Dixon és mtsai. 2002b, 2010).

\subsubsection{A tau és phi csoportú Arabidopsis thaliana GST-k}

A növényspecifikus tau (GSTU) és phi (GSTF) GST csoportokat, amelyek gyakran stressz indukálhatóak, citotoxikus és xenobiotikus detoxifikáló aktivitással rendelkeznek és szerepet játszanak a védekező mechanizmusokhoz kapcsolódó másodlagos anyagcserében (Dixon és mtsai. 2002a, Dixon és Edwards 2010). Mindkét csoportban találunk magas glutation konjugációs- és glutation-függő peroxidáz aktivitással rendelkező tagokat (Dixon és mtsai. 2009). Az ide sorolható GST-k génduplikációk sorozatán mentek keresztül, és így a legtöbb taggal (28, ill. 13) rendelkező csoportokat alkotják (Edwards és mtsai. 2010).

A tau csoportba tartozó GST-k tanulmányozását megnehezíti az enzimcsoport mérete. Az AtGSTU-k 3 kládot alkotnak (3. ábra), ennek az elkülönülésnek a funkcionális jelentősége egyelöre ismeretlen. Az első kládba az U1-től U10-ig terjedő GST-k tartoznak, azonban ezek a szekvenciák kevésbé vizsgáltak (Dixon és Edwards 2010). A második kládba tartozó GST-k (AtGSTU11-től AtGSTU18-ig) közül az AtGSTU17 az egyik legjobban ismert. Jiang és mtsai. (2010) eredményei alapján az AtGSTU17 a phyA-szabályozás alatt álló fotomorfogenezisben vesz részt, és a növényi hormonokkal együtt a glutation homeosztázis változtatásán keresztül szerepe van a lúdfü fejlődésének szabályozásában. Chen és mtsai. (2012) Arabidopsis Atgtu17 null-mutánsban megemelkedett sótoleranciát mutattak ki, amely a mutáns növények megemelkedett GSH és abszcizinsav szintjével volt kapcsolatban. Az AtGSTU17 glutation homeosztázisban betöltött szerepe kihat a redox állapot és a stresszválasz gének szabályozására és feltehetően a stressz jelátvitel negatív szabályozójaként funkcionál (Chen és mtsai. 2012). A harmadik kládba tartozó szekvenciák (AtGSTU19-AtGSTU28) közül az AtGSTU19 egyike a leginkább tanulmányozott GST-knek. Expresszióját indukálják herbicid antidótumok (DeRidder és mtsai. 2002) és a szárazság stressz is (Bianchi és mtsai. 2002). Az 
AtGSTU20 túltermeltetése és csökkent expressziója esetén is a távoli vörös fénnyel szembeni érzékenység csökkenését észlelték (Chen és mtsai, 2007). Az AtGSTU24 és AtGSTU26 GST-k génexpressziója xenobiotikumok hatására magas indukciót mutattak (Mezzari és mtsai. 2005, Nutricati és mtsai. 2006), proteomikai analízis eredményeként pedig az AtGSTU27 szalicilsav általi indukciója volt kimutatható (Gruhler és mtsai. 2005). Az AtGSTU25 és AtGSTU28 magas aktivitással rendelkeznek CDNB-vel szemben és az AtGSTU25 CHP-vel szemben is magas aktivitást mutat. Mindkettő rövid láncú zsírsav-glutation termékeket köt, de míg az AtGSTU25 hidroxilált, addig az AtGSTU28 nem hidroxilált zsírsavakat (Dixon és Edwards 2009, Dixon és mtsai. 2009).

Lúdfüben 13 phi csoportba tartozó GST szekvencia ismert, amelyek számozása az AtGSTF2től AtGSTF14-ig tart (Dixon és Edwards 2010). (Az eredetileg AtGSTF1-ként elnevezett szekvenciát a genom szekvenálás után nem tudták azonosítani.) Közülük kiemelhető az AtGSTF2, amelynek transzkripciója indukálódik oxidatív stressz és növényi hormonok hatására (Mang és mtsai. 2004, Gong és mtsai. 2005), és emellett ligandin funkciójának köszönhetően a flavonoidok eloszlását szabályozza (Smith és mtsai. 2003). Az AtGSTF6 és AtGSTF7 indukciót mutatnak stressz során (Lieberherr és mtsai. 2003), és az AtGSTF7 SA hatására indukálódik mRNS- és fehérje szinten egyaránt (Sappl és mtsai. 2004). Az AtGSTF8 egyike a legjelentősebb lúdfü GST-knek, ami ugyan kloroplasztisz target szekvenciát hordoz az N-terminálisán, de nagyobb mértékben található a citoplazmában, mivel a target peptid gyakran lehasad a fehérje érése során (Thatcher és mtsai. 2007). Amíg az AtGSTF8 expressziója $\mathrm{H}_{2} \mathrm{O}_{2}$ és fitohormonok hatására indukálódik, addig az AtGSTF9 állandó magas expresszióval jellemezhető gén (Wagner és mtsai. 2002, Sappl és mtsai. 2004).

\subsubsection{GST-k szerepe a sóstresszben}

A GST gének expresszióját és protein szintjét a növekedésszabályozók és stresszfaktorok beleértve az eltérő koncentrációban és időtartamig alkalmazott SA és a $\mathrm{NaCl}$ kezeléseket képesek befolyásolni (Wagner és mtsai. 2002, Sappl és mtsai. 2004 és 2009, Zhang és mtsai. 2012). A GST-k részt vesznek a növények sóstressz akklimatizációjában, aminek során stresszválaszra specifikus izoenzimek aktiválódnak.

Termesztett paradicsomon (Solanum lycopersicum) és vad típusú rokon faján (S. pennellii) végzett kísérletben megfigyelték, hogy a sókezelés különböző módon hatott a két növényfajra. 
A vad típusú növényfaj képes volt visszaszorítani a sókezelés hatására jelentkező oxidatív stresszt, így nem növekedett meg a $\mathrm{H}_{2} \mathrm{O}_{2}$ - és lipid peroxidok szintje a kloroplasztiszban, ellentétben a S. lycopersicum-mal, ami károsodott a fellépő oxidatív stressz hatására. A $S$. pennellii kloroplasztiszában antioxidánsok csoportja indukálódott sóstressz alatt, ezek között voltak a SOD, APX, MDHAR, GST, foszfolipid hidroperoxid glutation peroxidáz (GPX) és POD enzimek (Mittova és mtsai. 2002). A sótoleráns vad paradicsom (Solanum pimpinellifolium'PI365967') és egy sószenzitív nemesített fajta (Solanum lycopersicum cv. 'Moneymaker') transzkriptomikai összehasonlítása a toleráns genotípusban számos GST magasabb szintű expresszióját mutatta ki (Sun és mtsai. 2010). Ezen felül számos sóstressz hatására indukálódó GST gént csak a szenzitív fajtában azonosítottak. A szerzők azt a következtetést vonták le, hogy ezek a gének a nemesítés során veszthették el magas expresszáltságukat, azonban só hatására képesek indukálódni és a toleráns vad típusúéhoz hasonló transzkriptum szintet elérni. A különböző csoportokba tartozó GST-k szerepe a paradicsom növények sóstressz akklimatizációjában azonban még nem ismert.

Rizs növényeken alkalmazott sóstressz során a lambda GST családba tartozó OsGSTL1 repressziója volt megfigyelhetö, míg az OsGSTL2 és OsGSTL3 expressziója nem változott (Kumar és mtsai. 2013). Sóstressz és abszcizinsav hatására rizs gyökerében az OsGSTU3 gyors indukcióját tapasztalták, míg az OsGSTU4 később fejeződött ki és csak sóstressz hatására (Moons 2003). Az OsGSTU4 gént Arabidopsis transzgenikus vonalakban túltermeltetve megemelkedett só- és oxidatív stressz toleranciát figyeltek meg, és a transzgenikus növényekben jellemző volt számos, a stresszválaszban és a sejt detoxifikálásában szerepet játszó gén indukciója (Sharma és mtsai. 2014).

Dohány GST transzformánsokon végzett kísérletekben bizonyították, hogy a GST gének túltermeltetése elősegítheti a sóstressz tolerancia kialakulását. Salicornia brachiata SbGSTU és szója (Glycine soja) GsGSTU génjének túltermelése magasabb csírázási arányt és jobb növekedést eredményezett sóstressz során a vad típushoz képest (Jha és mtsai. 2011). Ezen felül megfigyelték, hogy a GST túltermelő dohány transzformánsok módosult antioxidáns aktivitással rendelkeztek. A megemelkedett GST aktivitás mellett nőtt a GR, APX, DHAR és MDHAR aktivitás, valamint megváltozott az Asc és GSH szintje, ezáltal csökkentve az oxidatív károsodást a növényekben (Roxas és mtsai. 2000, Le Martret és mtsai. 2011). 


\subsection{A SA szerepe a sóstressz akklimatizációban és az edződés folyamatában}

A SA számos fiziológia folyamatot befolyásol, nem csak azokat, amelyek szorosan a biotikus stresszhez, hanem az abiotikus stressz akklimatizációhoz kapcsolódóakat is (Horváth és mtsai. 2007, Hayat és mtsai. 2010, Joseph és mtsai. 2010). Ezzel együtt a biotikus és abiotikus stressz során gyakran fellépő oxidatív stressz válaszban is szerepet játszik (Shirasu és mtsai. 1997). Külsőleg alkalmazva a SA-at megfigyelték a SA védő hatását, amennyiben egy átmeneti oxidatív stresszt követően indukálta az antioxidáns védekező rendszert és egyes stabilizáló anyagok szintézisét (Szepesi és mtsai. 2009, Poór és mtsai. 2011, Tari és mtsai 2015). Ezek a változások teszik lehetővé, hogy a SA-at, mint „hardening” (általánosabban elfogadott nevén ,priming”) molekulát alkalmazzák az oxidatív károsodás csökkentésének érdekében (Pál és mtsai. 2013). A sejtek összetett enzimatikus és nem-ezimatikus antioxidánsokból álló rendszert fejlesztettek ki, amelynek segítségével kioltják a stresszfolyamatok során keletkező ROS-t (Ahmad és mtsai. 2010, Kocsy és mtsai. 2011). A SA kezelés csökkentette a sóstressz okozta károsodásokat az antioxidáns kapacitás erősítése révén (Szepesi és mtsai. 2008, Palma és mtsai. 2009, Khan és mtsai. 2010, Rivas-San Vicente és Plasencia 2011, Syeed és mtsai. 2011, Tari és mtsai. 2015).

A külsőleg megfelelő koncentrációban alkalmazott SA hatékonyan indukálja a „priming”-ot (kémiai edződés), ami lehetővé teszi a gyorsabb és hatékonyabb stressz választ egy későbbi stressz esetén, ezáltal védelmet biztosít számos abiotikus stresszel szemben is (Horváth és mtsai. 2007) többek között elősegíti a sóstressz akklimatizációt (Tari és mtsai. 2002). Számos növényfajban, így a lúdfüben (Lee és Park 2010, Jayakannan és mtsai 2013), paradicsomban (Tari és mtsai. 2002, Stevens és mtsai. 2006), tehénbabban (Khan és mtsai 2010), kukoricában (Gunes és mtsai. 2007), árpában (El-Tayeb 2005), napraforgóban (Noreen és mtsai. 2009) és mustárban (Syed és mtsai. 2011) leírták, hogy a SA védelmet nyújt a sóstressz során fellépő károsodások ellen. A SA paradicsom növényekben nagy számban aktiválta a gének átírását már a sóstressz korai szakaszában (Ouyang és mtsai. 2007).

Vigna radiata L. és paradicsom növényekben a SA kezelés sóstressz során hatékonyabb fotoszintézist és növekedést eredményezett és elősegítette a növények ozmotikus adaptációját (Stevens és mtsai. 2006, Szepesi és mtsai. 2009, Poór és mtsai. 2011, Khan és mtsai. 2014). Vigna radiata L. esetében lecsökkentette az etilén szintjét, hozzájárulva a hatékonyabb fotoszintézishez és az oxidatív stressz csökkentéséhez (Khan és mtsai. 2014). A külsőleg alkalmazott SA kezelés segítette a növények sóstressz rezisztenciájának kialakulását azáltal is, 
hogy megemelte az ABS tartalmat, ami a stressz kivédésében fontos reakciókat indukált, megemelte a karotinoidok és poliaminok szintjét, ami a ROS szint szabályozásához járult hozzá (Shakirova és mtsai. 2003, Szepesi és mtsai. 2009).

A megemelkedett (sncl) vagy csökkent $(\mathrm{NahG})$ endogén SA tartalommal rendelkező mutáns vagy transzgenikus lúdfü vonalakkal kapott eredmények alapján a SA feltételezhetően közvetlenül hozzájárul a NaCl-indukálta növekedés csökkentéséhez és a metabolizmus felborulásához (Hao és mtsai. 2012). Asensi-Fabado és mtsai. (2011) kísérleteikben az aba3 mutánsban az ABS hiánya megváltoztatta a növények növekedését és SA szintjét, ami a mérsékelt sóstressz türést segítette elő. A növekedés gátlása, mintegy szükséges rossz járult hozzá a stressz toleranciához, és ezáltal optimalizálta a növény a hormonszintjeit.

A SA sóstresszben betöltött szerepével kapcsolatban még mindig vannak ellentmondások. Hao és mtsai. (2012) megállapították, hogy a SA-hiány vagy a jelátvitel akadályozása Arabidopsis növényekben elösegítette a sós környezethez történő adaptációt, a SA bioszintézisben károsodott sid2 Arabidopsis mutánsok viszont hiperszenzitívnek bizonyultak a sóstresszel szemben (Alonso-Ramirez és mtsai. 2009).

A sid2 mutánsok csírázása érzékenyebb volt a magas sókoncentrációra a vad típushoz és a $N a h G$ vonalhoz képest is, és alacsonyabb POD aktivitással rendelkeztek sóstressz alatt. A $N a h G$ egy bakteriális szalicilát-hidroxiláz, amely a SA-t antioxidáns hatással rendelkező pirokatechinné alakítja. A NahG vonalakban az antioxidáns hatású pirokatechin megemelkedett szintje magyarázata lehet a sóstressz során mutatott jobb csírázásnak a sid2 mutánsokhoz képest. Lúdfü $N a h G$ növényekben a megemelkedett sótoleranciát a SA tartalom csökkenéséhez (Borsani és mtsai. 2001) és a magasabb össz-glutation és össz-aszkorbát tartalomhoz kapcsolták (Cao és mtsai 2008). A NahG növények magasabb GR és DHAR aktivitása szintén elősegíthette a jobb stressztürést. A magas SA tartalmú Cvi-0 növények viszont stressz körülmények között csökkent sóstressz toleranciát mutattak (Cao és mtsai. 2008). Lee és mtsai. (2010) ezzel szemben igazolták, hogy a SA nem esszenciális a csírázás folyamatában, de elősegíti az Arabidopsis növények csírázását sóstressz során, valószínűleg az oxidatív stressz csökkentésén keresztül. 


\section{Célkitüzések}

A lúdfü (Arabidopsis thaliana) a legjelentősebb genetikai modellnövény, amelyet gyakran alkalmaznak a kétszikűekben lejátszódó folyamatok tanulmányozására és leírására. A külsőleg alkalmazott SA kezelések „priming” hatásával már több évtizede foglalkoznak, azonban számos kérdés megválaszolatlan maradt. A korábban, paradicsom (Solanum lycopersicum Mill. L. cvar. Rio Fuego) növényeken kidolgozott hidropónikus rendszert alapul véve (Tari és mtsai. 2002, Szepesi és mtsai. 2009), lúdfü növényeket több héten keresztül kezeltünk különböző koncentrációban SA-val, hogy egy olyan rendszert hozzunk létre, amelyben a SA-indukált ,priming” folyamatát egy másodlagosan alkalmazott stresszválaszban, jelen esetben a sóstressz válaszban, tanulmányozhatjuk. Paradicsom növényekkel szemben, ahol 3 hét elökezelést követően alkalmazott 1 hét $100 \mathrm{mM} \mathrm{NaCl}$ hatását vizsgálták, lúdfüben 2 hét SA előkezelés bizonyult megfelelőnek a „priming” kiváltásához, a másodlagosan alkalmazott sókezelés káros hatásának enyhítéséhez.

Munkánk során a széles koncentrációintervallumban alkalmazott SA elökezelés hatását vizsgáltuk Arabidopsis thaliana L. és Solanum lycopersicum L. Mill. cvar. Rio fuego növényeken sóstressz alatt.

A dolgozatban a következő kérdésekre kerestünk választ:

Arabidopsis thaliana L. növényen végzett hosszútávú kísérletekben:

1. Hogyan hatnak a különböző SA koncentrációk a lúdfü növények növekedésére és egyéb fiziológiai paramétereire? Hogyan befolyásolja a több hétig tartó elökezelés a később alkalmazott sóstresszre adott választ? Milyen változásokat idéz elő a SA az enzimatikus antioxidánsok aktivitásában és milyen módon befolyásolja a sóstressz választ?

2. Melyek azok a SA koncentrációk, amelyek sikeresen indukálják a ,priming”-ot a növényekben és milyen fiziológiai változásokkal hozható összefüggésbe a sikeresebb akklimatizáció? 
3. Hogyan változnak a GST és GPOX aktivitások az elökezelések és a másodlagosan alkalmazott sótressz hatására? Van-e összefüggés a növények GST aktivitásában mért változások és a kiválasztott GST gének expressziója között?

Arabidopsis thaliana L. GST mutáns növényeken végzett rövid távú kísérletekben:

4. Kihatással van-e egyetlen GST mutációja a növények életképességére és GST aktivitására kontroll, NaCl- és SA kezelés során? Milyen fenotípusos változást idézhet elő egyetlen GST gén mutációja a magas só- és SA kezelések során?

Solanum lycopersicum Mill. L. cvar. Rio Fuego növényeken végzett kísérletekben:

5. Milyen változásokat idéz elő a SA ,priming” a paradicsom növények GST és GPOX aktivitásában? Van-e összefüggés az aktivitásban mért különbségek és a GST gének kifejeződése között?

6. Az ABS szintjében megfigyelt változások magyarázhatóak-e az AO aktivitásának és az ABS bioszintézis gének kifejeződésének különbségeivel?

7. Milyen hasonlóság illetve különbség van a két vizsgált növényfaj esetében a SA előkezeléssel indukált priming jelenségben, sóstressz akklimatizációban?

8. Találunk-e összefüggést a vizsgált GST gének expressziójának változása és az 5' végi szabályozó régióban lévő cisz-elemek között? Mennyire hasonlóak a vizsgált szabályozó elemek az ortológ szekvenciákban? 


\section{Anyagok és módszerek}

\subsection{Növénynevelési körülmények}

\subsubsection{Lúdfü (Arabidopsis thaliana, Col-0)}

\subsubsection{Növények nevelése és kezelése a hosszútávú kisérletek során}

A lúdfü (Arabidopsis thaliana L. Col-0) növényeket hidropónikus kultúrában neveltük. Ehhez a magokat sterileztük, aminek a menete következő volt: 1 percig tartó 70\%-os etanolos mosást 10 perc 2\%-os Domestosban történő áztatás követtet, amit 5 egymást követő steril vizes mosással távolítottunk el a steril magokról. A steril magokat egy éjszakán keresztül $4{ }^{\circ} \mathrm{C}$-on tartottuk, majd vágott végü Eppendorf csövekbe öntött táptalajra ültettük (4. ábra). A növények 10 literes edényekben (4. ábra), Hoagland tápoldatban nőttek, aminek az összetétele: $5 \mathrm{mM} \mathrm{Ca}\left(\mathrm{NO}_{3}\right)_{2}, 5 \mathrm{mM} \mathrm{KNO} 3,1 \mathrm{mM} \mathrm{KH_{2 } \mathrm { PO } _ { 4 } , 2 \mathrm { mM } \mathrm { MgSO }}$, $1 \mu \mathrm{M}$ Fe-EDTA, $0,0475 \mu \mathrm{M} \mathrm{H}_{2} \mathrm{BO}_{3}, 14,48 \mu \mathrm{M} \mathrm{MnCl}, 0,8148 \mu \mathrm{M} \mathrm{ZnCl}_{2}, 0,3731 \mu \mathrm{M} \mathrm{CuCl}_{2}, 0,001213 \mu \mathrm{M}$ $\mathrm{Na}_{2} \mathrm{MoO}_{4}, p H=5,8$. A nevelés kontrollált körülményeit növénynevelő kamra segítségével biztosítottuk (Fitoclima S 600 PLH, Aralab, Portugal), ahol $21{ }^{\circ} \mathrm{C}$-os állandó hőmérsékleten, $100 \mu \mathrm{mol} \mathrm{m} \mathrm{m}^{-2} \mathrm{~s}^{-1}$ fényintenzitáson, $10 / 14$ fény/sötét periódusban és $70 \%$ relatív páratartalom mellett növekedtek a növények a kísérlet teljes ideje alatt. Öt héten keresztül kontroll körülmények között neveltük a növények és a tápoldat cseréje hetente történt (4. ábra). A szalicilsav kezelés hatásának vizsgálatához az 5 hetes lúdfü növényeket kisebb (1 literes) edényekbe helyeztük (4. ábra), amibe a tápoldatot adott koncentrációjú, $10^{-9}-10^{-4} \mathrm{M} \mathrm{SA}$ oldattal egészítettük ki és a tápoldatot hetente kétszer cseréltük. A $10^{-4} \mathrm{M}$ SA kezelés nagymértékben gátolta a növények növekedését, így ezt a koncentrációt nem alkalmaztuk a hosszútávú kísérleteink során (1. melléklet).

A $10^{-9}-10^{-5}$ M SA elökezelés sóstressz válaszban betöltött szerepének vizsgálatához 2 hét SA kezelést követően a tápoldatot $100 \mathrm{mM} \mathrm{NaCl-dal} \mathrm{egészítettük} \mathrm{ki,} \mathrm{egy} \mathrm{héten} \mathrm{keresztül.} \mathrm{A}$ mintavétel 3 héttel a SA előkezelés és 1 héttel a sókezelés megkezdése után történt. A mérésekhez a növények gyökerét és jól kifejlett levelét használtuk. Minden kísérletet legalább kétszer ismételtünk meg és a méréseket három párhuzamossal végeztük. 

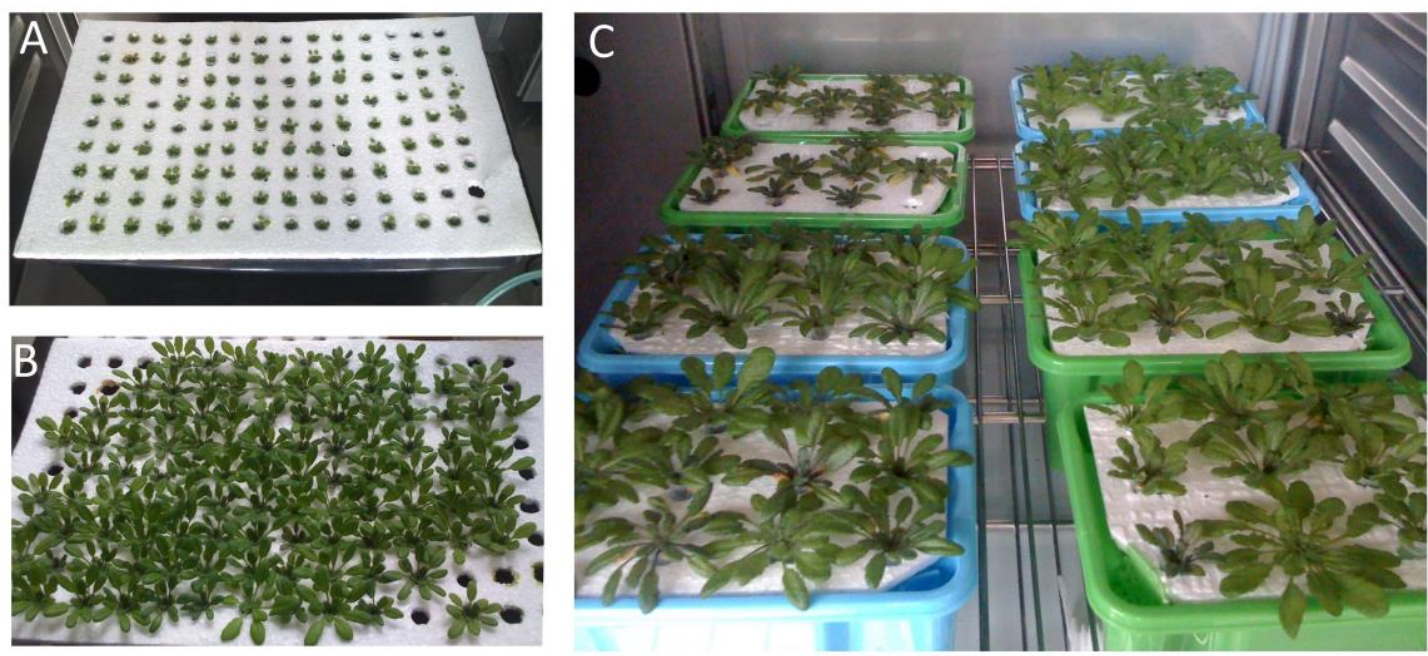

4. ábra: A lúdfü növények nevelési körülményei a hosszútávú kísérletek során. A magokat táptalajt tartalmazó, vágott végü Eppendorfokban csíráztattuk (A) és 5 hetes korukig Hoagland tápoldatban neveltük (B). A SA elökezelés és az azt követő $100 \mathrm{mM} \mathrm{NaCl}$ kezelés kisebb (1 literes) nevelőedényekbe áthelyezve történt $(\mathrm{C})$.

\subsubsection{Rövidtávú kísérletek nevelési és kezelési körülményei}

Kísérleteinket 14 napos vad típusú és GST mutáns lúdfü növényekkel végeztük. A magok sterilezése a hosszútávú kísérletekben leírtak szerint történt. A sterilezést követően a magokat szilárd 1⁄2 erősségű Murashige-Skoog (MS) táptalajra ültettük ki (Murashige és Skoog, 1962), amely tartalmazott 1\% szacharózt, 0,8\% agart (w/v) és Gamborg B5 vitaminnal kiegészített MS tápsót. A táptalaj pH-ját 5,7-5,8-ra állítottuk be. A növényeket 2 hétig neveltük kontroll körülmények között $2{ }^{\circ} \mathrm{C}$-on, $100 \mu \mathrm{mol} \mathrm{m} \mathrm{m}^{-2} \mathrm{~s}^{-1}$ fényintenzitáson $10 / 14$ fény/sötét periódusban és $60 \%$ relatív páratartalom mellett, majd 48 órára áthelyeztük őket $150 \mathrm{mM} \mathrm{NaCl-dal} \mathrm{vagy}$ $10^{-5}$ M SA-val kiegészített $1 / 2$ erősségű MS táptalajra (5. ábra). A mintavétel 2 nap elteltével történt, a gyökeret és a hajtást nem választottuk szét.

A gyökérnövekedés méréséhez a csíranövényeket a felületi sterilezést követően $1 / 2 \mathrm{MS}$ táptalajon neveltük 4 napon keresztül, ezután helyeztük át a növényeket $150 \mathrm{mM} \mathrm{NaCl-dal}$ vagy $10^{-5} \mathrm{M}$ SA-val kiegészített $1 / 2 \mathrm{MS}$ táptalajra, szögletes Petri-csészékbe (5. ábra). A növekedést függőlegesen elhelyezett Petri-csészékben, az áthelyezéstől számított 14 napon keresztül követtük nyomon, majd fényképfelvétel készítése után számítógépes programmal végeztük a kiértékelést. A gyökerek hosszát ImageJ szoftver segítségével határoztuk meg. 

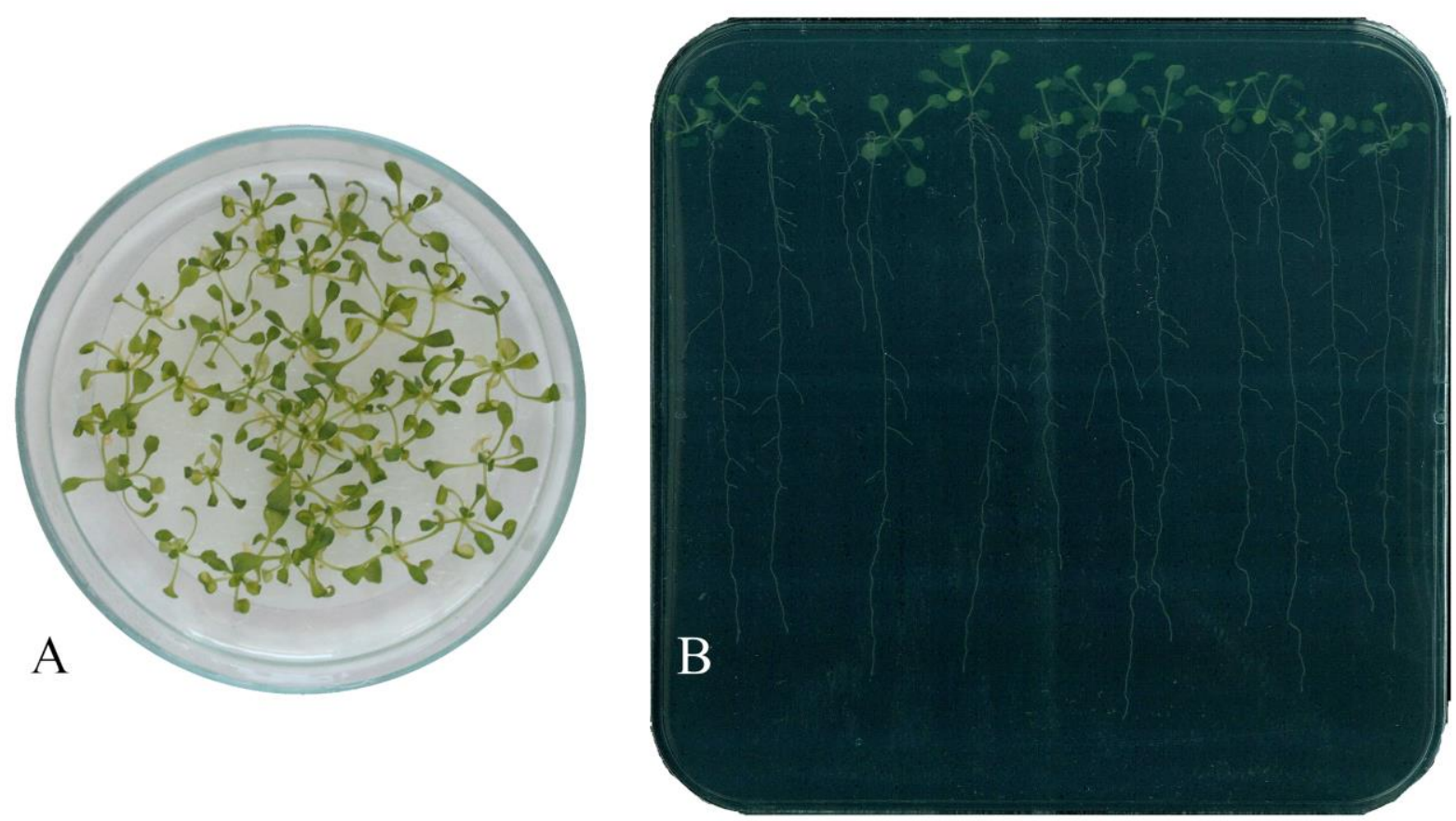

5. ábra: Lúdfü növények nevelési körülményei rövidtávú Petri-csészés kísérletek során. A csíranövényeket. A lúdfü csíranövényeket 2 hetes korukban helyeztük át $\mathrm{NaCl}$ - vagy SA tartalmú táptalajokra (A). A gyökérnövekedés vizsgálatához 4 napos csíranövényeket helyeztünk szögletes Petri-csészébe, kontroll ( $\left.1 \frac{1}{2} \mathrm{MS}\right), \mathrm{NaCl}$ ill. SA tartalmú táptalajokra (B).

\subsubsection{Paradicsom (Solanum lycopersicum Mill. L. cvar. Rio Fuego)}

Kísérleteink során Solanum lycopersicum Mill. L. cvar. Rio Fuego paradicsom növényeket használtunk fel. A növények nevelése és kezelése Szepesi és mtsai. (2009) cikkében leírtak alapján történt. A csíráztatás 3 napon keresztül sötétben, $26{ }^{\circ} \mathrm{C}$-on történt. Ezt követően a növények két hetes korukig perlitben majd vízkultúrában, üvegházi körülmények között növekedtek. A tápoldat összetétele a következő volt: $2 \mathrm{mM} \mathrm{Ca}\left(\mathrm{NO}_{3}\right)_{2}, 1 \mathrm{mM} \mathrm{MgSO} 4,0,5 \mathrm{mM}$ $\mathrm{KH}_{2} \mathrm{PO}_{4}, 0,5 \mathrm{mM} \mathrm{Na} \mathrm{HPO}_{4}, 0,5 \mathrm{mM} \mathrm{KCl}$ és a mikroelemek $\left(10^{-6} \mathrm{M} \mathrm{MnSO}_{4}, 5 \cdot 10^{-7} \mathrm{M}\right.$ $\left.\mathrm{ZnSO}_{4}, 10^{-7} \mathrm{M} \mathrm{CuSO}_{4}, 10^{-7} \mathrm{M}\left(\mathrm{NH}_{4}\right)_{6} \mathrm{Mo}_{7} \mathrm{O}_{24}, 10^{-5} \mathrm{M} \mathrm{H}_{3} \mathrm{BO}_{4}\right), 2 \cdot 10^{-5} \mathrm{M}$ Fe-EDTA, pH=5,8. A növényeket 12 órás nappali és 12 órás éjszakai periódus, $300 \mu \mathrm{mol} \mathrm{m} \mathrm{m}^{-2}$ fényintenzitás és 55-60\%-os relatív páratartalom mellett neveltük. A SA kezelést a növények 4 hetes korától 8 hetes koráig végeztük $10^{-7}$ és $10^{-4} \mathrm{M} \mathrm{SA}$ oldatokkal. A sókezelés 7 hetes paradicsom növényeken történt 3 hét $\mathrm{SA}$ elökezelést követően. A mintákat a $100 \mathrm{mM} \mathrm{NaCl}$ alkalmazásának megkezdése után 7 nappal vettük (6. ábra). A mérésekre a gyökereket és a csúcshoz legközelebb eső, már kifejlett leveleket használtuk. 


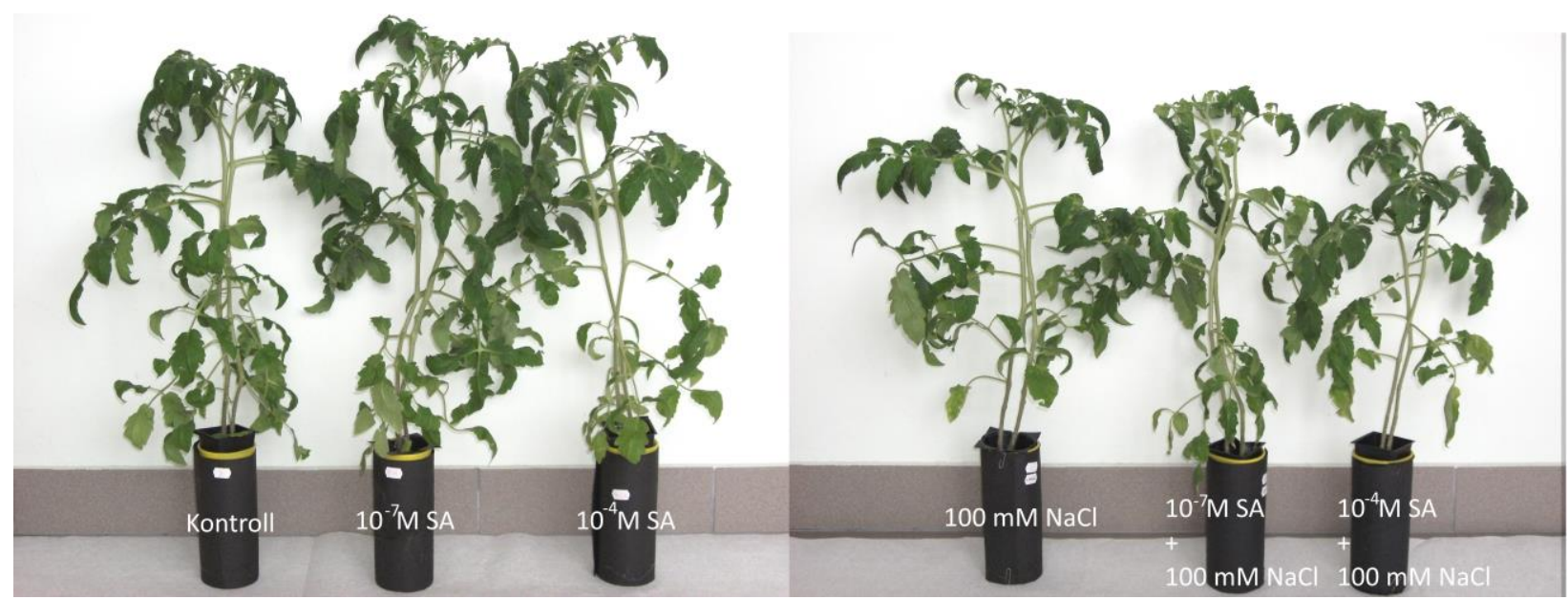

6. ábra: Nyolc hetes paradicsom növények 3 hét SA elökezelést és egy hét $100 \mathrm{mM} \mathrm{NaCl}$ kezelést követően.

\subsection{Elemtartalom meghatározás induktív csatolású plazma tömegspektrométerrel}

A 8 hetes vad típusú Arabidopsis thaliana (Col-0) növények elemtartalom meghatározása a tanszékünkön található induktív csatolású plazma tömegspektrométer (ICP-MS, Thermo Scientific XSeries II, Asheville, USA) segítségével történt, a gyökérből és a levelekből elkülönítve végeztünk elemanalízist. A 72 órás $70{ }^{\circ} \mathrm{C}$-on történő szárítás után salétromsavat $(65 \%, w / v)$ és hidrogénperoxidot $(30 \%, w / v)$ adtunk a mintákhoz, ezt követően pedig egy mikrohullámú roncsoló (MarsXpress CEM, Matthews, USA) segítségével 200 C-on, $1600 \mathrm{~W}$ teljesítmény mellett, 15 percen keresztül roncsoltuk a növényi részeket. A lehütött mintákat ezután megfelelő mértékben hígítottuk desztillált vízzel, majd az ICP-MS készülékkel meghatároztuk az elemtartalmakat. Az adatokat $\mathrm{mg} \mathrm{g}^{-1}$ száraz tömeg (SZT) mértékegységben fejeztük ki.

\section{3 Életképesség meghatározása és reaktív oxigénformák detektálása fluoreszcens mikroszkóppal}

Fluoreszcein diacetát (FDA) festéket alkalmaztunk a sejtek életképességének meghatározására lúdfü csíranövényekben. Az FDA egy membrán permeábilis fluorofór, amit a sejten belüli észterázok alakítanak fluoreszkáló formává. Csak azok a sejtek mutatnak fluoreszcenciát, melyekben az észterázok jól működnek, vagyis az FDA az élő sejteket festi meg (Gémes és mtsai. 2011). A csíranövényeket sötétben, szobahőmérsékleten, $2 \mathrm{ml} 10 \mu \mathrm{M}$ festékoldatban inkubáltuk 30 percen keresztül, majd 20 perc alatt 4-szer mostuk 2-(Nmorfolin)-etánszulfonsav/kálium klorid (MES/KCl, $10 \mathrm{mM} / 50 \mathrm{mM}, \mathrm{pH}$ 6,15) pufferrel. $\mathrm{Az}$ 
így előkészített mintákat nagy felbontású digitális kamerával felszerelt (Axiocam HR, HQ CCD kamera, 1300x1030 dpi, Carl Zeiss, Jéna, Németország) mikroszkóppal vizsgáltuk, a Zeiss Axiovert 200M típusú fluoreszcens mikroszkóp 10-es filterjét használtuk a méréshez (exc.: 450-490 nm, em.: 515-565 nm), és a pixel intenzitásokat a gyökérben (150 $\mu \mathrm{m}$-rel a csúcstól $80 \mu \mathrm{m}$ átmérőjü körökben) és sziklevélben (600 $\mu \mathrm{m}$ átmérőjü körökben) egyaránt meghatároztuk.

A ROS in situ detektálására a $\mathrm{H}_{2}$ DCFDA (2'-7'-diklorodihidrofluoreszcein diacetát) festéket

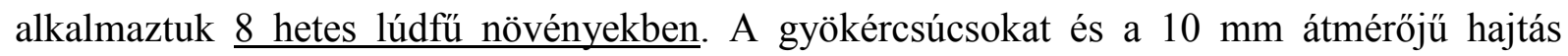
korongokat 15 percen keresztül festettük $37{ }^{\circ} \mathrm{C}$-on, $10 \mu \mathrm{M} \mathrm{H}_{2}$ DCFDA oldattal, Pető és mtsai. (2013) alapján. A festés után 20 percen belül négyszer mostuk a mintákat MES/KCl pufferrel (10 mM/50 mM, pH 6,15), majd mikroszkópos tárgylemezre helyeztük őket. Az így előkészített mintákat nagy felbontású digitális kamerával felszerelt (Axiocam HR, HQ CCD kamera, 1300x1030 dpi, Carl Zeiss, Jéna, Németország), Zeiss Axiovert 200M típusú fluoreszcens mikroszkóppal vizsgáltuk, a 10-es filterjét használtuk a méréshez. A $\mathrm{H}_{2}$ DCFDAval festett minták esetében a ROS zöld fluoreszcenciájának alapján az Axiovision Rel. 4.6 nevü szoftver segítségével mértük a pixel intenzitást a gyökércsúcsokban $300 \mu$ m-rel a csúcstól, $200 \mu \mathrm{m}$ átmérőjü körökben és a hajtás korongokban $600 \mu \mathrm{m}$ átmérőjü körökben. A körök átmérőjét nem változtattuk a mérések során.

\section{4 $\mathrm{A} \mathrm{H}_{2} \mathrm{O}_{2}$ tartalom kvantitatív meghatározása}

A $\mathrm{H}_{2} \mathrm{O}_{2}$ tartalmakat spektrofotometriásan határoztuk meg, a SA-, illetve a sókezelt hajtás és gyökér mintákban Velikova (2000) módszere alapján. A friss növényi anyagot (400 mg) $750 \mu 10,1 \%$-os triklórecetsavban (TCA) homogenizáltuk, majd centrifugálás után (10 $000 \mathrm{~g}$, 20 perc, $\left.4{ }^{\circ} \mathrm{C}\right) 0,25 \mathrm{ml}$ felülúszóhoz hozzáadtunk $0,25 \mathrm{ml}$ foszfát puffert $(10 \mathrm{mM}, \mathrm{pH}=7,0)$ és $0,5 \mathrm{ml}$ kálium-jodid $(1 \mathrm{M})$ oldatot. A reakciótermék mérését 10 perc inkubálást követően $390 \mathrm{~nm}$-en végeztük $10 \mathrm{mM}$ foszfát pufferrel szemben. $\mathrm{A} \mathrm{H}_{2} \mathrm{O}_{2}$ tartalmakat, 0,1-5 $\mu \mathrm{mól} \mathrm{ml}^{-1}$ $\mathrm{H}_{2} \mathrm{O}_{2}$ koncentrációsorral készített kalibrációs görbe segítségével állapítottuk meg.

\subsection{A malondialdehid tartalom meghatározása}

A malondialdehid (MDA) a lipidek peroxidációjának terméke, mennyiségét tiobarbitursavval való reakciója alapján lehet meghatározni. E szerint a módszer szerint az MDA mellett a stresszhatásra megjelenő reaktív aldehidek is detektálhatóak (Ederli és mtsai. 1997). Az MDA 
meghatározásához 100 mg gyökér vagy hajtás mintát homogenizáltunk $1 \mathrm{ml}$ 0,1\% TCA-val; a további lipidperoxidáció megakadályozására $100 \mu 14 \%$ butilált hidroxitoluolt (BHT) adtunk az extraktumhoz. $4{ }^{\circ} \mathrm{C}$-on, $10000 \mathrm{~g}$-n történő, 20 perces centrifugálás után a felülúszó

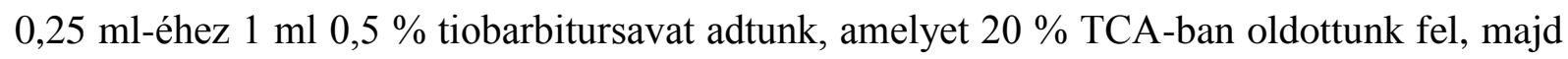
30 percig inkubáltuk $96{ }^{\circ} \mathrm{C}$-os vízfürdőben. Az abszorbanciát $532 \mathrm{~nm}$-nél mértük, amit a 600 nm-nél mért nem-specifikus értékkel korrigáltunk. Az MDA koncentrációt $155 \mathrm{mM}^{-1} \mathrm{~cm}^{-1}$ extinkciós koefficienssel számoltuk.

\subsection{Az antioxidáns enzimek aktivitásának meghatározása}

Az antioxidáns enzimek aktivitásának meghatározásához minden esetben 200 mg növényi gyökér vagy hajtás szövetet homogenizáltunk jégen $1 \mathrm{ml}$ extrakciós pufferben, amely 100 $\mathrm{mM}$ foszfát pufferben ( $\mathrm{pH} 7,0), 1 \mathrm{mM}$ fenilmetilszulfonil-fluoridot (PMSF) és 1\% polivinilpolipirrolidont (PVPP) tartalmazott. Ezt követően 20 percig centrifugáltuk a mintákat $4{ }^{\circ} \mathrm{C}$-on, 10000 g-n és a felülúszót használtuk az enzimaktivitás mérésére.

\subsubsection{Szuperoxid-dizmutáz (SOD) (EC 1.15.1.1)}

A SOD aktivitást az NBT riboflavin jelenlétében történő fotokémiai redukciójának gátlása alapján határoztuk meg (Dhindsa és mtsai, 1981). Az $1 \mathrm{ml}$ reakcióelegy 25-25 $\mu 1$ enzimkivonatot, $50 \mathrm{mM}$ tetrazólium kéket (NBT) és $0,2 \mathrm{mM}$ riboflavint tartalmazott. A 15 perc után keletkezett formazán extinkcióját 560 nm-en mértük. Egy enzimegység (U) azt az enzimmennyiséget jelenti, amely az NBT redukciójának $50 \%$-os gátlását okozza fény jelenlétében. Az enzimaktivitást $\mathrm{U} \mathrm{g}^{-1}$ friss tömeg (FT) egységben adtuk meg.

\subsubsection{Kataláz (KAT) (EC 1.11.1.6)}

A KAT aktivitását a $\mathrm{H}_{2} \mathrm{O}_{2}$ lebontásának nyomon követésével határoztuk meg $240 \mathrm{~nm}$ hullámhosszon spektrofotométerrel, az 1. és 2. perc között mért extinkcióváltozás alapján. Hajtásban $100 \mu 1$, gyökérben 10-szeresére hígított mintából, $5 \mu$ enzimkivonat, $50 \mathrm{mM}, \mathrm{pH}$ 7,0 foszfát puffert ill. $1 \%$-os $\mathrm{H}_{2} \mathrm{O}_{2}$-ot tartalmazó, $1 \mathrm{ml}$ térfogatú reakcióelegyben mértük. Egy $\mathrm{U}$ az az enzimmennyiség, amely $1 \mu \mathrm{mol} \mathrm{H}_{2} \mathrm{O}_{2}$ elbontását katalizálja 1 perc alatt (Upadhyaya és mtsai. 1985). 


\subsubsection{Gvajakol peroxidáz (POD) (EC 1.11.1.7)}

A POD aktivitásának meghatározására $470 \mathrm{~nm}$ hullámhosszon, a gvajakol oxidációja során történő abszorbancia növekedés detektálásával történt. $\varepsilon_{470}=26.6 \mathrm{mM}^{-1} \mathrm{~cm}^{-1}$. A hajtás esetében $25 \mu$, gyökérnél pedig 10-szeresére hígított mintából $5 \mu$ l fehérjekivonatot, $1 \%$-os gvajakolt, $50 \mathrm{mM}, \mathrm{pH} 7,0$ foszfát puffert 1,5 ml végtérfogatban tartalmazó elegyben a reakciót $1 \%$-os $\mathrm{H}_{2} \mathrm{O}_{2}$ oldat hozzáadásával indítottuk. A mért abszorpció 1 perc alatti növekedéséből számítottuk az enzimaktivitást. Egy U-nak azt az enzimmennyiséget tekintettük, amely $1 \mu$ mól tetragvajakol képződését katalizálta 1 perc alatt (Upadhaya és mtsai, 1985).

\subsubsection{Glutation transzferáz (GST), glutation peroxidáz (GPOX) és dehidroaszkorbát reduktáz (DHAR) aktivitás meghatározása}

A GST aktivitást (EC 2.5.1.18) egy mesterséges szubsztrát, az 1-klór-2,4-dinitrobenzol (CDNB) segítségével határoztuk meg spektrofotometriás méréssel (Habig és mtsai. 1974). A reakcióelegy végtérfogata $1 \mathrm{ml}$ volt, $100 \mathrm{mM}$ foszfát pufferhez $(\mathrm{pH}$ 6,5) mértünk $3 \mu \mathrm{M}$ redukált glutationt (GSH) és a reakciót $1 \mu \mathrm{M}$ CDNB hozzáadásával indítottuk el. A 340 nmen mért extinkció változásból az 1. és 2. perc közötti értékek felhasználásával számoltunk. $\varepsilon_{340}$ $=6,22 \mathrm{mM}^{-1} \mathrm{~cm}^{-1}$, egy $\mathrm{U}$ az az enzimmennyiség, amely 1 perc alatt $1 \mu$ mól konjugált terméket képez. Az enzim aktivitását $1 \mathrm{~g}$ FT-re vonatkoztatva adtuk meg ( $\left.\mathrm{U} \mathrm{g}^{-1} \mathrm{FT}\right)$.

A glutation peroxidáz (EC. 1.11.1.9) aktivitást Awasthi és munkatársai (1975) által kidolgozott módszer alapján végeztük, kumén hidroperoxid (CHP) szubsztráttal (Csiszár és mtsai. 2004). A reakcióelegy 4 mM GSH-t, 0,2 mM NADPH-t, 1 U élesztő extraktumból tisztított GR enzimet, $100 \mu$ l enzimkivonatot, 0,25 mM CHP-t és $100 \mathrm{mM}$ foszfát puffert (pH $7,0)$ tartalmazott $1 \mathrm{ml}$ végtérfogatban. A reakciót CHP hozzáadásával indítottuk, az extinkciót 340 nm-en mértük GSH-t és NADPH-t nem tartalmazó mintával szemben, a számoláshoz a 3. és 4. perc közötti értékeket használtuk fel. A nem-specifikus NADPH oxidáció figyelembe vételéhez az extinkció különbséget meghatároztuk CHP nélkül is. $\varepsilon_{340}=6,22 \mathrm{mM}^{-1} \mathrm{~cm}^{-1}$, az egy perc alatt fogyott NADPH-t $\mu$ mól-ban megadva fejeztük ki az enzimegységet (U), az enzim müködését $1 \mathrm{~g}$ friss tömegre vonatkoztattuk $\left(\mathrm{U} \mathrm{g}^{-1} \mathrm{FT}\right)$.

DHAR (EC. 1.8.5.1) aktivitását Edwards és Dixon (2005) alapján végeztük el. A reakcióelegyben $100 \mathrm{mM}$ foszfát pufferhez $(\mathrm{pH}$ 6,5) mértünk $0,5 \mathrm{mM}$ dehidroaszkorbátot és a reakciót $5 \mathrm{mM}$ redukált glutationnal indítottuk. A 265 nm-en mért extinkció változásból az 1 . 
és 2. perc közötti értékek felhasználásával számoltunk. $\varepsilon_{265}=14,0 \mathrm{mM}^{-1} \mathrm{~cm}^{-1}$, az egy perc alatt keletkezett aszkorbátot $\mu$ mól-ban megadva fejeztük ki az enzimegységet (U), az enzim müködését $1 \mathrm{~g}$ friss tömegre vonatkoztattuk $\left(\mathrm{U} \mathrm{g}^{-1} \mathrm{FT}\right)$.

\subsection{Az abszcizin-aldehid oxidáz (AO) (EC 1.2.3.1) aktivitás mérése}

Aldehid oxidáz (AO) aktivitás detektálása poliakrilamid gélelektroforézissel (PAGE) történt. A méréshez $2 \mathrm{ml}$ extraháló elegyben (összetétele: $1 \mathrm{mM}$ EDTA, $5 \mathrm{mM} \mathrm{GSH}, 5 \mu \mathrm{M}$ FAD, 1 mM DTT-ditiotreitol, 0,5 mM L-cisztein, $250 \mathrm{mM}$ Tris puffer $\mathrm{pH}$ 7,5, $40 \mu \mathrm{M} \mathrm{Na} \mathrm{MoO}_{4} \cdot \mathrm{H}_{2} \mathrm{O}$, 0,1 mM PMSF, $8 \mu \mathrm{M}$ antipain) dörzsöltük el a mintákat (1g) és centrifugálást követően (10 perc, $10000 \mathrm{~g}$ ) a felülúszót használtuk a méréshez. A fehérjetartalom meghatározása után (Bradford 1976) a hajtásból $300 \mu \mathrm{g}$, a gyökérből $100 \mu \mathrm{g}$ fehérje és tizedmennyiségü brómfenolkék festéket tartalmazó szacharózos mintafelvivő puffer (50\% szacharóz, 0,1\% brómfenolkék) került felvitelre zsebenként a poliakrilamid (5 és 7,5\% szeparáló és stacking) gélre. Szubsztrátként $1 \mathrm{mg} \mathrm{ml}^{-1}$ 2-naftaldehidet használtunk $0,1 \mathrm{mM}$ fenazin metoszulfátot és 1 mM MTT-t (3[4,5-dimetiltiazol-2-il]-2,5-difeniltetrazólium-bromid) tartalmazó, 0,1 M Tris$\mathrm{HCl}$ pufferben $(\mathrm{pH} 8,5)$. A keletkező színreakció kvantifikálását KODAK Elektroforézis Dokumentációs és Analízis Rendszer (EDAS) 290 felhasználásával, KODAK 1D Image Analysis szoftver (Eastman Kodak Company, 2000-2001) segítségével végeztük (Sagi és mtsai. 1998).

\subsection{Szekvencia keresés, filogenetikai és promóter analízis}

A paradicsom GST (SlGST), ZEP (SlZEP), NCED (SlNCED), CCD (SlCCD) és AO (SlAO) szekvenciákat in silico a SOL Genomics Network (SGN) adatbázisában (http://solgenomics.net), a lúdfü GST (AtGST), NCED (AtNCED) és CCD (AtCCD) szekvenciákat pedig a The Arabidopsis Information Resource (TAIR) adatbázisában (https://www.arabidopsis.org) azonosítottuk. Az SlGST-ként számon tartott nukleinsav és fehérje szekvenciákat az SGN adatbázis kereső felületének segítségével kigyüjtöttük. A rendelkezésre álló aminosav szekvenciákat, amelyek feltehetően különböző GST fehérjéket kódolnak ClustalW szoftver segítségével illesztettük (EMBL-EBI/ClustalW, Thompson és mtsai. 1994). Ezt követően egy 200 aminosavból álló régió felhasználásával, amely tartalmazta az irodalomból ismert konzervatív régiókat és doméneket, rokonsági fát hoztunk létre Neighbour-Joining módszerrel, a MEGA5 és Dendroscope3 programokkal (Tamura és 
mtsai. 2011; Huson és mtsai. 2007). A további vizsgálatok céljából kiválasztott szekvenciák start kodon előtti 1,5 kbp hosszú szakaszán cisz-ható elemeket kerestünk a PlantCARE (http://bioinformatics.psb.ugent.be/webtools/plantcare/html/) adatbázisban.

Az SINCED és SICCD szekvenciákból álló törzsfa elkészítése során az SIGST szekvenciákhoz hasonló módon jártunk el, amelyek esetében azonban a teljes aminosav szekvencia hosszt felhasználtuk a rokonsági fa létrehozásához.

\subsection{RNS izolálás, cDNS átírás és QRT-PCR (kvantitatív valós idejü polimeráz láncreakció)}

Az össz növényi RNS preparálást 100 mg kiindulási anyagból, Chomczynski és Sacchi (1987) szerint végeztük, Csiszár és mtsai. (2014) alapján. Az RNS minták genomi DNS szennyezettségétől való megtisztításához DNáz (Thermoscientific) kezelést végeztünk, majd a tisztított RNS mintából összesen $1 \mu \mathrm{g}$-ot MMLV reverz transzkriptázzal (Thermoscientific) cDNS-sé alakítottunk random hexamer primerek (Biotium) segítségével, a reakciót $20 \mu 1$ végtérfogatban végeztük, a gyártó (Thermoscientific) utasításait követve. Az így kapott cDNS-t használtuk a továbbiakban a QRT-PCR reakciókhoz a vizsgált gének kifejeződésének nyomon követésére. A kiválasztott génre az oligonukleotidokat a Primer 3 szoftver (http://frodo.wi.mit.edu/) segítségével terveztük, a primereket táblázatban foglaltuk össze (2. és 3. mellékletek). A szintetizált cDNS-eket 1: 20 arányban hígítottuk nukleáz mentes vízzel. A reakcióelegy $20 \mu$ l végtérfogat volt, amiben az egyes oligonukleotidok $150 \mu \mathrm{M}$ végkoncentrációban voltak jelen, valamint $9 \mu 1$ a hígított cDNS-ből és $10 \mu 1$ a 2x SYBR Green PCR Master Mixből. Minden reakció esetében legalább három párhuzamos mérést végeztünk. A kvantitatív RT-PCR-t BioRad (Hercules, California) Real-Time PCR Detektorral végeztük. A reakció 10 perces $90{ }^{\circ} \mathrm{C}$-os hevítéssel kezdődött, majd 41 ciklus következett az alábbi paraméterekkel: $95^{\circ} \mathrm{C}$-on 15 másodperc és $60{ }^{\circ} \mathrm{C}$-on 1 perc. A SYBRGreen festék fluoreszcencia intenzitását a ciklusok során minden amplifikációs lépés után detektáltuk Opticon Monitor szoftver segítségével (BioRad, Hercules, California). A PCR lefutását követően a termék specifikusságát olvadási görbe detektálásával ellenőriztük: $55{ }^{\circ} \mathrm{C}$-tól $90{ }^{\circ} \mathrm{C}$-ig $\left(0,2{ }^{\circ} \mathrm{C} \quad 0,2 \mathrm{~s}^{-1}\right)$. Az adatok analíziséhez a $2^{-\Delta \Delta \mathrm{Ct}}$ módszert alkalmaztuk (Livak és Schmittegen, 2001 ). A referenciagének paradicsom esetében a glicerinaldehid-3foszfát dehidrogenáz (GAPDH) és elongációs faktor $1 \alpha$ alegysége (EF 1- $\alpha$ ) voltak (Lovdal és Lillo 2009, Orellana és mtsai. 2010) (3. melléklet). Az SlGST-k, SIZEP, SINCED, SlCCD-k és SIAO-k expressziójában bekövetkező változások szemléltetésére a relatív transzkript szintet a 
kontroll mintákban génenként egynek tekintettük. A lúdfüből történt mérésekhez referencia génekként a 18S rRNS (At3g41768 és At2g01010) és az aktin2 (At3g18780) géneket alkalmaztuk (Masclaux-Daubresse és mtsai. 2007, Papdi és mtsai. 2008) (2. melléklet). Az aktin2 stabil expressziót mutatott a kísérleteinkben, ezért a későbbi normalizáláshoz ezt használtuk. Az AtGST-k expressziójának szemléltetésére génenként egynek tekintettük a kontroll növényekben mért relatív transzkripciós szinteket és ehhez viszonyítottunk.

\subsection{Statisztikai értékelés}

A kísérleteket minimum két biológiai ismétlésben végeztük el, legalább 3-3 (növekedés esetében 12, ROS és $\mathrm{H}_{2} \mathrm{O}_{2}$ esetében 10) párhuzamos méréssel. A dolgozatban bemutatott adatok egy reprezentatív kísérlet adataiból számított átlag értékek a hozzá tartozó szórással (standard deviancia, $\pm \mathrm{SD}$ vagy standard error, $\pm \mathrm{SE}$ ). A vizsgálati eredmények matematikaistatisztikai feldolgozását és kiértékelését a SigmaPlot 11.0 (Systat Software Inc, USA) szoftverrel végeztük. A kontrolltól való szignifikáns különbségeket a varianciaanalízist követően a Duncan teszt alkalmazásával állapítottuk meg. A Duncan teszt alkalmazásakor a különböző betűvel jelölt oszlopok szignifikánsan különböznek egymástól $\mathrm{P} \leq 0,05$ valószínűségi szinten. 


\section{Eredmények}

\subsection{Lúdfü növények növekedésében bekövetkező változások SA előkezelés és azt követő sóstressz hatására}

A hidropónikus kultúrában nőtt 5 hetes növények $10^{-9}-10^{-5} \mathrm{M}$ szalicilsavval történő kezelése 3 hét után szignifikánsan növelte a lúdfü növények rozetta átméröjét, hajtás- és gyökértömegét, a gyökerek hosszában azonban nem idézett elő szignifikáns változást (7. és 8 . ábrák). A sóstressz, amelyet $100 \mathrm{mM} \mathrm{NaCl}$ tápoldathoz történő hozzáadásával idéztünk elö 2 hét SA előkezelést követően 7 hetes növényeken, egy hét elteltével jelentősen csökkentette a növények hajtástömegét és kismértékben a rozetta átmérőjét, azonban gyökér hosszban és tömegben nem idézett elő szignifikáns változást. Az alkalmazott sóstressz a vizsgált növekedési paraméterekben csökkenést idézett elö 2 hét SA elökezelést követően is, viszont ezeknél a növényeknél a kontrollnál magasabb hajtás- és gyökértömeget mértünk. Egy hétig tartó sókezelés után a $10^{-5} \mathrm{M}$ SA-val elökezelt növények rendelkeztek a legnagyobb rozettával és legmagasabb hajtás- és gyökértömeggel, ami arra utal, hogy ezeknek a növényeknek a növekedése és stressztolarenciája is pozitívan változott (8. ábra).

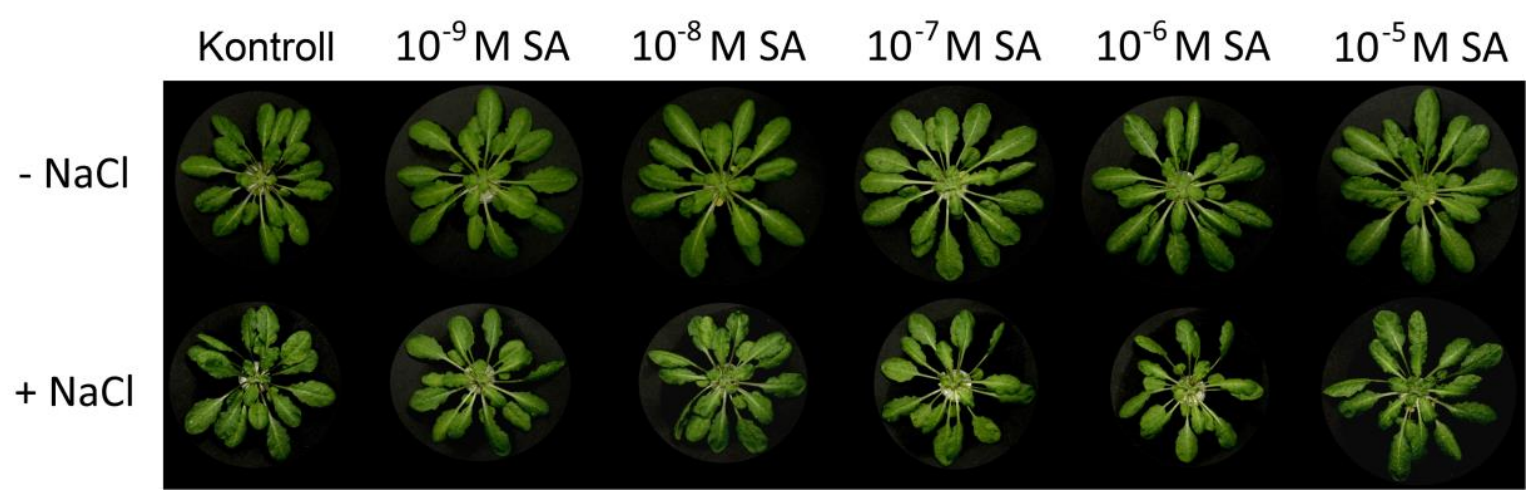

7. ábra: Nyolc hetes, tölevélrózsás lúdfü növények két hét SA kezelés $\left(10^{-5}-10^{-9} \mathrm{M}\right)$ és egy hét só $(100 \mathrm{mM} \mathrm{NaCl})$ kezelést követően. A „- $\mathrm{NaCl}$ ” jelölés a csak SA-kezelt, a „, $\mathrm{NaCl}$ ” jelölés a SA előkezelést követő só kezelést jelenti. 

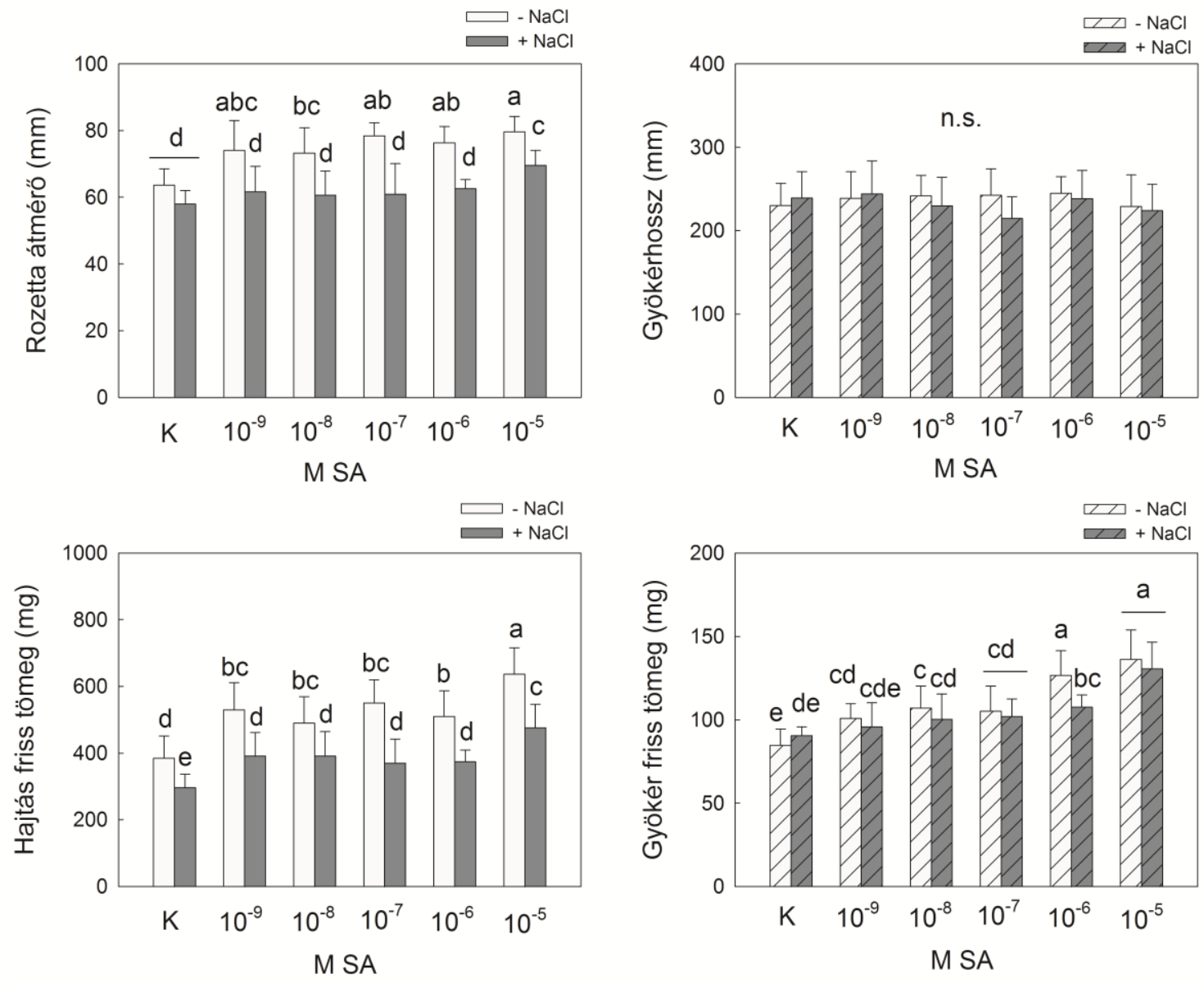

8. ábra: Nyolc hetes lúdfü növények rozetta átméröjének, gyökér hosszának, hajtás- és gyökér tömegének változása a két hét SA elökezelést követően alkalmazott egy hét $100 \mathrm{mM}$ $\mathrm{NaCl}$ kezelés hatására. (- $\mathrm{NaCl}$ : nem sókezelt minták; + $\mathrm{NaCl}$ : $100 \mathrm{mM} \mathrm{NaCl}$ - dal kiváltott sóstressznek kitett növények; K: kontroll; M SA: a szalicilsav koncentrációja mól $1^{-1}$-ben kifejezve). A különböző betűvel jelölt oszlopok szignifikánsan különböznek egymástól $\mathrm{P} \leq 0,05$ valószínüségi szinten Duncan teszt alapján. (Átlag $\pm \mathrm{SD}, \mathrm{n}=12$ )

\subsection{Elemtartalom változása a SA előkezelést és a sóstresszt követően}

Nyolc hetes lúdfü növények $\mathrm{K}$ - és $\mathrm{Na}$ tartalma már SA elökezelés hatására módosult. Levélben minden SA kezelés lecsökkentette a K szintjét, gyökérben viszont csak a $10^{-5} \mathrm{M} \mathrm{SA}$ kezelés hatására csökkent a szövetek K tartalma. A Na tartalom koncentrációtól függő módon változott. Levélben a $10^{-9}-10^{-7} \mathrm{M}$ SA kezelések csökkentették a Na tartalmat, $10^{-6}$ és $10^{-5} \mathrm{M}$ SA kezelések pedig növelték azt. Gyökérben a fordítottja volt megfigyelhető: az alacsonyabb koncentrációk elősegítették a $\mathrm{Na}$ felvételét, a magasabb koncentrációk viszont kis mértékben csökkentették a Na szintet. $100 \mathrm{mM} \mathrm{NaCl}$ kezelés hatására a $\mathrm{K}$ tartalom lecsökkent levélben 
és gyökérben is, emellett a Na akkumulálódott mindkét szervben. A SA előkezelés a levélben és a gyökérben különböző módon hatott. A SA elökezelés hatására kisebb mértékü volt a levélben a $\mathrm{K}$ tartalom csökkenése, sőt a $10^{-5} \mathrm{M}$ SA előkezelés a kontrollhoz képest magasabb K szintet eredményezett levelekben. A SA előkezelt növények levelében sóstressz hatására a kontrollhoz viszonyítva nagyobb mértékű Na halmozódott fel. Gyökérben a K tartalom a SA elökezelés után magasabb volt a sóstresszt követően föként a $10^{-6}$ és $10^{-5} \mathrm{M} \mathrm{SA}$ koncentrációk esetében, ahol ezzel párhuzamosan a $\mathrm{Na}$ tartalom alacsonyabb maradt. A $10^{-9}-10^{-7} \mathrm{M} \mathrm{SA}$ elökezelések után viszont magasabb Na tartalmat mértünk a növények gyökerében sóstresszt követően (1. és 2. táblázat).

1. táblázat: $\mathrm{A} 10^{-9}-10^{-5} \mathrm{M} \mathrm{SA}$ elökezelés hatása lúdfü növények levelének $\mathrm{K}$ és $\mathrm{Na}$ tartalmára, $\mathrm{mg} \mathrm{g}^{-1}$ száraz tömegre (SZT) vonatkoztatva (átlag $\pm \mathrm{SD}$ ). A különböző betűvel jelölt oszlopok szignifikánsan különböznek egymástól $\mathrm{P} \leq 0,05$ valószínűségi szinten Duncan teszt alapján.

\begin{tabular}{|c|c|c|c|c|c|c|c|c|}
\hline \multicolumn{9}{|c|}{ Levél } \\
\hline \multirow{2}{*}{$\begin{array}{l}\text { SA } \\
\text { (M) }\end{array}$} & \multicolumn{4}{|c|}{$\mathrm{K}\left(\mathrm{mg} \mathrm{g}^{-1} \mathrm{SZT}\right)$} & \multicolumn{4}{|c|}{$\mathrm{Na}\left(\mathrm{mg} \mathrm{g}^{-1} \mathrm{SZT}\right)$} \\
\hline & \multicolumn{2}{|c|}{$-\mathrm{NaCl}$} & \multicolumn{2}{|c|}{$+\mathrm{NaCl}$} & \multicolumn{2}{|c|}{$-\mathrm{NaCl}$} & \multicolumn{2}{|c|}{$+\mathrm{NaCl}$} \\
\hline $\bar{K}$ & 52,95 & $\pm 3,42^{a}$ & 35,22 & $\pm 2,03^{\text {ef }}$ & 0,18 & $\pm 0,00^{\mathrm{e}}$ & 35,14 & $\pm 0,91^{\mathrm{c}}$ \\
\hline $10^{-9}$ & 42,94 & $\pm 3,20^{\mathrm{cd}}$ & 32,57 & $\pm 0,49^{\mathrm{f}}$ & 0,08 & $\pm 0,01^{\mathrm{e}}$ & 35,56 & $\pm 2,29^{\circ}$ \\
\hline $10^{-8}$ & 45,40 & $\pm 1,79^{\mathrm{bc}}$ & 32,56 & $\pm 1,04^{\mathrm{f}}$ & 0,09 & $\pm 0,00^{\mathrm{e}}$ & 30,41 & $\pm 0,78^{\circ}$ \\
\hline $10^{-7}$ & 47,58 & $\pm 4,25^{\mathrm{b}}$ & 32,98 & $\pm 2,63^{\mathrm{f}}$ & 0,09 & $\pm 0,00^{\mathrm{e}}$ & 60,95 & $\pm 0,02^{\mathrm{a}}$ \\
\hline $10^{-6}$ & 46,89 & $\pm 2,85^{\mathrm{bc}}$ & 34,20 & $\pm 1,62^{\text {ef }}$ & 0,37 & $\pm 0,01^{\mathrm{e}}$ & 39,88 & $\pm 2,03^{b}$ \\
\hline $10^{-5}$ & 21,40 & $\pm 0,25^{\mathrm{g}}$ & 38,73 & $\pm 0,96^{\mathrm{de}}$ & 0,24 & $\pm 0,00^{\mathrm{e}}$ & 40,45 & $\pm 2,32^{b}$ \\
\hline
\end{tabular}

2. táblázat: A $10^{-9}-10^{-5} \mathrm{M}$ SA előkezelés hatása lúdfü növények gyökérzetének $\mathrm{K}$ és $\mathrm{Na}$ tartalmára, $\mathrm{mg} \mathrm{g}^{-1}$ száraz tömegre (SZT) vonatkoztatva (átlag $\pm \mathrm{SD}$ ). A különböző betűvel jelölt oszlopok szignifikánsan különböznek egymástól $\mathrm{P} \leq 0,05$ valószínűségi szinten Duncan teszt alapján.

\section{Gyökér}

\begin{tabular}{|c|c|c|c|c|c|c|c|c|}
\hline \multirow{2}{*}{$\begin{array}{l}\text { SA } \\
(\mathrm{M})\end{array}$} & \multicolumn{4}{|c|}{$\bar{K}\left(\mathrm{mg} \mathrm{g}^{-1} \mathrm{SZT}\right)$} & \multicolumn{4}{|c|}{$\mathrm{Na}\left(\mathrm{mg} \mathrm{g}^{-1} \mathrm{SZT}\right)$} \\
\hline & \multicolumn{2}{|c|}{$-\mathrm{NaCl}$} & \multicolumn{2}{|c|}{$+\mathrm{NaCl}$} & \multicolumn{2}{|c|}{$-\mathrm{NaCl}$} & \multicolumn{2}{|c|}{$+\mathrm{NaCl}$} \\
\hline $\bar{K}$ & 62,00 & $\pm 4,27^{\text {cd }}$ & 46,16 & $\pm 4,13^{f}$ & 0,79 & $\pm 0,06^{\mathrm{e}}$ & 18,31 & $\pm 1,26^{b}$ \\
\hline $10^{-9}$ & 76,57 & $\pm 2,66^{\mathrm{a}}$ & 49,33 & $\pm 0,55^{\mathrm{ef}}$ & 1,57 & $\pm 0,02^{\text {de }}$ & 20,51 & $\pm 0,38^{\mathrm{a}}$ \\
\hline $10^{-8}$ & 70,30 & $\pm 0,83^{\mathrm{ab}}$ & 51,73 & $\pm 0,15^{\mathrm{ef}}$ & 2,44 & $\pm 0,00^{\mathrm{d}}$ & 20,65 & $\pm 0,51^{\mathrm{a}}$ \\
\hline $10^{-7}$ & 76,44 & $\pm 8,28^{\mathrm{a}}$ & 49,42 & $\pm 0,51^{\text {ef }}$ & 0,62 & $\pm 0,07^{\mathrm{e}}$ & 20,97 & $\pm 0,72^{\mathrm{a}}$ \\
\hline $10^{-6}$ & 65,76 & $\pm 4,01^{\mathrm{bc}}$ & 56,32 & $\pm 1,84^{\mathrm{de}}$ & 0,65 & $\pm 0,08^{\mathrm{e}}$ & 16,78 & $\pm 0,65^{\mathrm{c}}$ \\
\hline $10^{-5}$ & 45,37 & $\pm 1,23^{\mathrm{f}}$ & 54,27 & $\pm 0,13^{\mathrm{e}}$ & 0,65 & $\pm 0,04^{\mathrm{e}}$ & 16,62 & $\pm 0,60^{\mathrm{c}}$ \\
\hline
\end{tabular}


A K/Na aránya nagymértékben lecsökkent sóstressz után mind a kontroll, mind az SA-elökelt növényekben, azonban $10^{-6}$ és $10^{-5} \mathrm{M} \mathrm{SA}$ előkezelés a kontrollnál magasabb $\mathrm{K} / \mathrm{Na}$ arányt eredményezett a növények gyökerében (3. táblázat).

3. táblázat: $\mathrm{A} \mathrm{K} / \mathrm{Na}$ arány változása $10^{-9}-10^{-5} \mathrm{M}$ SA-val elökezelt lúdfü növényekben 1 hetes, 100 mM NaCl kezelést követően. Az adatokat az elemtartalmak átlagaiból számítottuk.

\begin{tabular}{lcccc}
\hline & \multicolumn{3}{c}{$\mathrm{K} / \mathrm{Na}$} \\
\hline SA (M) & \multicolumn{2}{c}{ Levél } & \multicolumn{2}{c}{ Gyökér } \\
& $-\mathrm{NaCl}$ & $+\mathrm{NaCl}$ & $-\mathrm{NaCl}$ & $+\mathrm{NaCl}$ \\
\hline $\mathrm{K}$ & 280,08 & 1,00 & 78,18 & 2,52 \\
$10^{-9}$ & 502,73 & 0,92 & 48,69 & 2,41 \\
$10^{-8}$ & 482,65 & 1,07 & 28,80 & 2,50 \\
$10^{-7}$ & 503,21 & 0,54 & 122,33 & 2,36 \\
$10^{-6}$ & 124,34 & 0,86 & 99,95 & 3,36 \\
$10^{-5}$ & 87,12 & 0,96 & 69,00 & 3,26 \\
\hline
\end{tabular}

\subsection{ROS és $\mathrm{H}_{2} \mathrm{O}_{2}$ tartalom $\mathrm{SA}$ előkezelt és sóstressznek kitett lúdfü növényekben}

A reaktív oxigénformák szintjét $\mathrm{H}_{2}$ DCFDA festéssel határoztuk meg. A SA elökezelt minták levelében és gyökércsúcsában a DCF fluoreszcencia nem mutatott szignifikáns eltérést 8 hetes növényeknél. Sókezelés hatására mindkét vizsgált szervben szignifikánsan magasabb volt a mikroszkóposan kimutatható ROS szintje, ez az emelkedés viszont nem volt megfigyelhető a SA-val előkezelt növényekben; kivételt képez a $10^{-6} \mathrm{M}$ SA elökezelést kapott növények gyökércsúcsa, amelyben a kontrolléhoz hasonló ROS szintet detektáltunk (9. ábra).

A teljes levél vagy gyökér felhasználásával, fotometriás módszerrel meghatározott $\mathrm{H}_{2} \mathrm{O}_{2}$ tartalom esetében a $10^{-9}-10^{-7} \mathrm{M}$ SA elökezelés hatására a növények levelében szignifikáns emelkedést mutattunk ki, míg a gyökerekben az összesen 3 hét SA kezelés minden alkalmazott koncentrációban kontrollhoz hasonló szintet eredményezett. Egy hetes, $100 \mathrm{mM} \mathrm{NaCl}$ kezelés szignifikánsan növelte a $\mathrm{H}_{2} \mathrm{O}_{2}$ mennyiségét a 8 hetes lúdfü növényekben, amely a $10^{-9}$ és $10^{-8} \mathrm{M}$ SA elökezelés esetén még fokozottabb volt. A magasabb koncentrációjú, $10^{-7}-10^{-5} \mathrm{M}$ SA-val elökezelt növények viszont a sókezelt kontrollhoz képest alacsonyabb $\mathrm{H}_{2} \mathrm{O}_{2}$ szintet mutattak (9. ábra). 

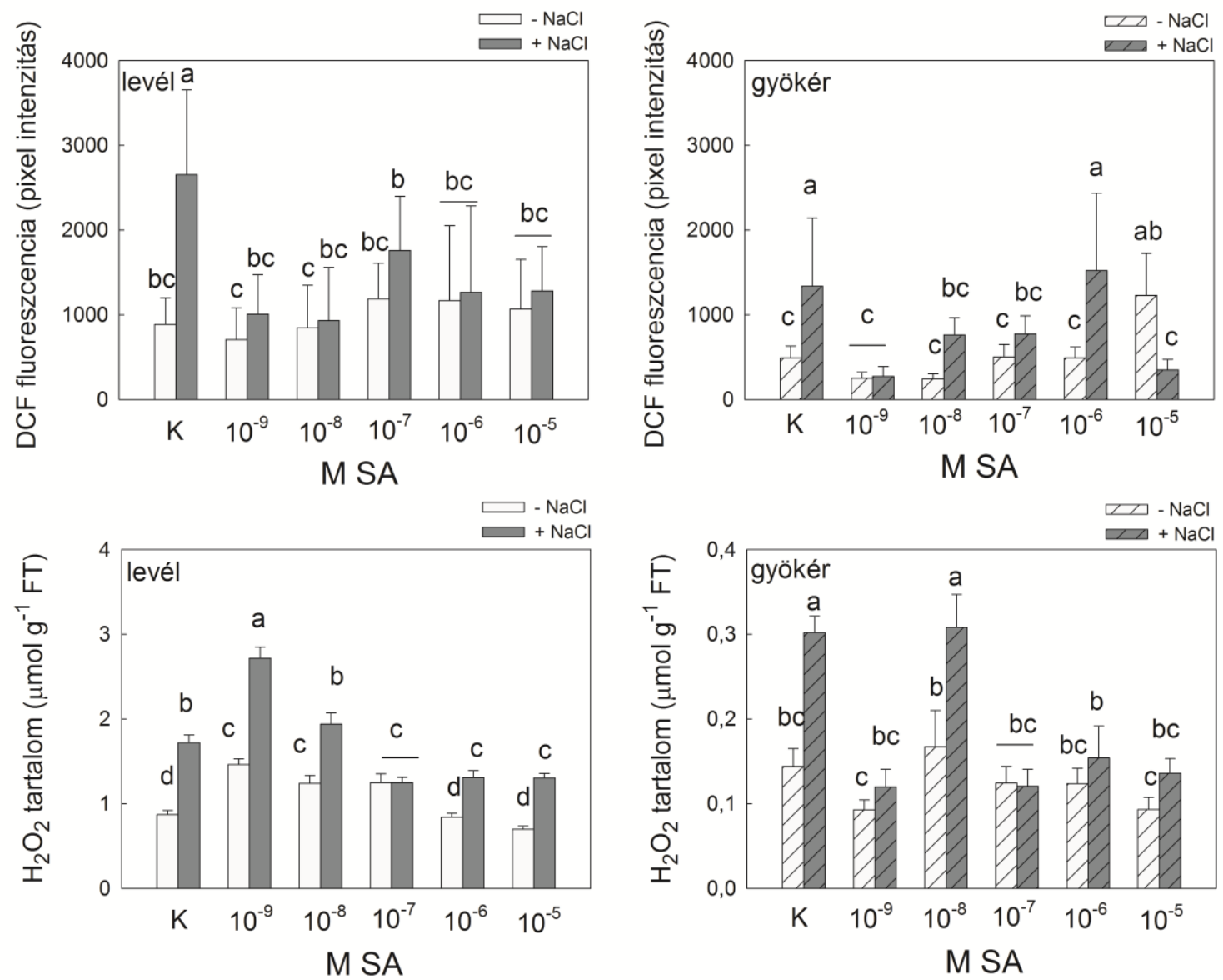

9. ábra: Nyolc hetes lúdfü növények reaktív oxigénforma (ROS) és $\mathrm{H}_{2} \mathrm{O}_{2}$ tartalma két hét SA előkezelés és egy hét sóstressz hatására. A ROS szintjét $\mathrm{H}_{2}$ DCFDA festést követően, a DCF fluoreszcencia pixelintenzitás változásának mérésével detektáltuk levél korongokban és a gyökércsúcsban. A $\mathrm{H}_{2} \mathrm{O}_{2}$ szint méréséhez a teljes levelet vagy gyökeret használtuk fel. Az x tengely feliratainak magyarázatát lásd a 8 . ábránál. A különböző betủvel jelölt oszlopok szignifikánsan különböznek egymástól $\mathrm{P} \leq 0,05$ valószínüségi szinten Duncan teszt alapján.

\subsection{A lipidperoxidáció mértékének meghatározása SA elökezelt lúdfü növényekben sóstressz során}

A növények károsodásának meghatározásához vizsgáltuk a 8 hetes lúdfü növényekben a lipidperoxidáció mértékét jelző malondialdehid tartalom alakulását. A SA előkezelt növényekben az MDA tartalom nem tért el szignifikánsan a kontrollban mérttől (10. ábra). Sókezelés hatására levélben az MDA tartalom szignifikáns emelkedést mutatott, ami $10^{-9}$ és $10^{-8} \mathrm{M}$ SA előkezelés hatására még tovább emelkedett. Magasabb koncentrációjú $\left(10^{-7}-10^{-5}\right.$ M) SA előkezelések nem okoztak további növekedést a lipidperoxidációban. Gyökérben ez a 
tendencia nem volt megfigyelhető, ugyanis sem a sóstressz, sem a SA előkezelés nem emelte szignifikánsan a mért MDA tartalmakat (10. ábra).
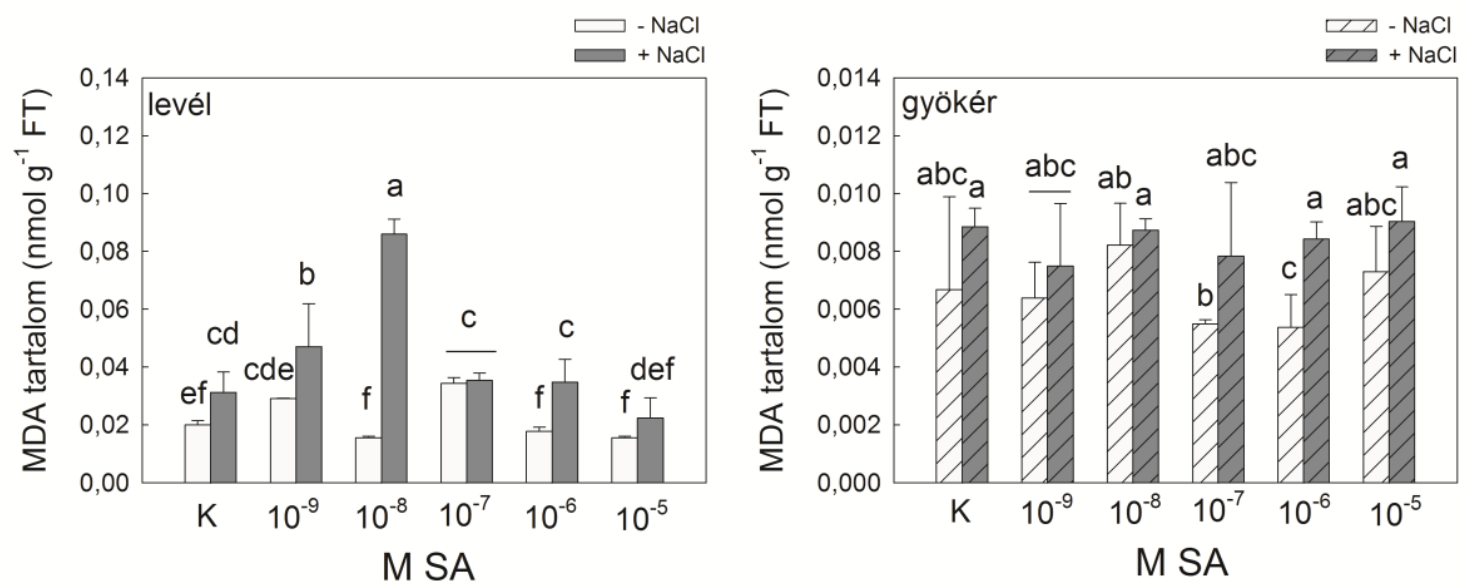

10. ábra: Malondialdehid (MDA) tartalom lúdfü növények levelében és gyökerében SA előkezelést és sóstresszt követően (Átlag $\pm \mathrm{SD}$ vagy $\mathrm{SE}, \mathrm{n}=3$ ). Az $\mathrm{x}$ tengely feliratainak magyarázatát lásd a 8 . ábránál. A különböző betüvel jelölt oszlopok szignifikánsan különböznek egymástól $\mathrm{P} \leq 0,05$ valószínüségi szinten Duncan teszt alapján.

\subsection{Az enzimatikus antioxidánsok aktivitása SA előkezelés és sóstressz alatt}

Három antioxidáns enzim, a szuperoxid-dizmutáz (SOD), kataláz (KAT) és gvajakol peroxidáz (POD) aktivitását vizsgáltuk SA előkezelésnek majd $100 \mathrm{mM} \mathrm{NaCl}$ kezelésnek kitett 8 hetes lúdfü növények levelében és gyökerében. Általánosságban elmondható, hogy az összesen 3 hét SA előkezelés nem idézett elő szignifikáns változást a SOD és POD aktivitásokban, kivételt képeznek ez alól a $10^{-6}$ és $10^{-5}$ M SA-kezelt növények, amelyeknek hajtásában a SOD, gyökerében pedig a POD aktivitása emelkedett meg az előkezelés hatására. A KAT aktivitása szignifikánsan lecsökkent mind hajtásban mind gyökérben az összes alkalmazott SA előkezelés hatására (11. ábra).

Egy hét sóstressz hatására mindhárom vizsgált enzim aktivitása szignifikánsan megemelkedett a gyökérben és lecsökkent a levélben. A SA elökezelés módosította a lúdfü növények sóstresszre adott válaszát. A SOD aktivitás a SA előkezelt növények gyökerében kontroll értéket mutatott, hajtásukban viszont $10^{-6} \mathrm{M}$ SA jelenlétében megemelkedett, $10^{-5} \mathrm{M}$ SA hatására pedig lecsökkent sóstressz során. A $100 \mathrm{mM} \mathrm{NaCl}$ kezelés lecsökkentette a KAT aktivitását a SA előkezelt lúdfü növények hajtásában, gyökérben azonban kontroll szintet 
mutatott vagy szignifikánsan megemelkedett az aktivitása. Amíg hajtásban a POD aktivitása az összes, elökezelésként alkalmazott SA koncentráció hatására nőtt, addig gyökérben csak a $10^{-7}-10^{-5}$ M SA előkezelések emelték meg szignifikánsan azt egy hét sóstressz után (11. ábra).
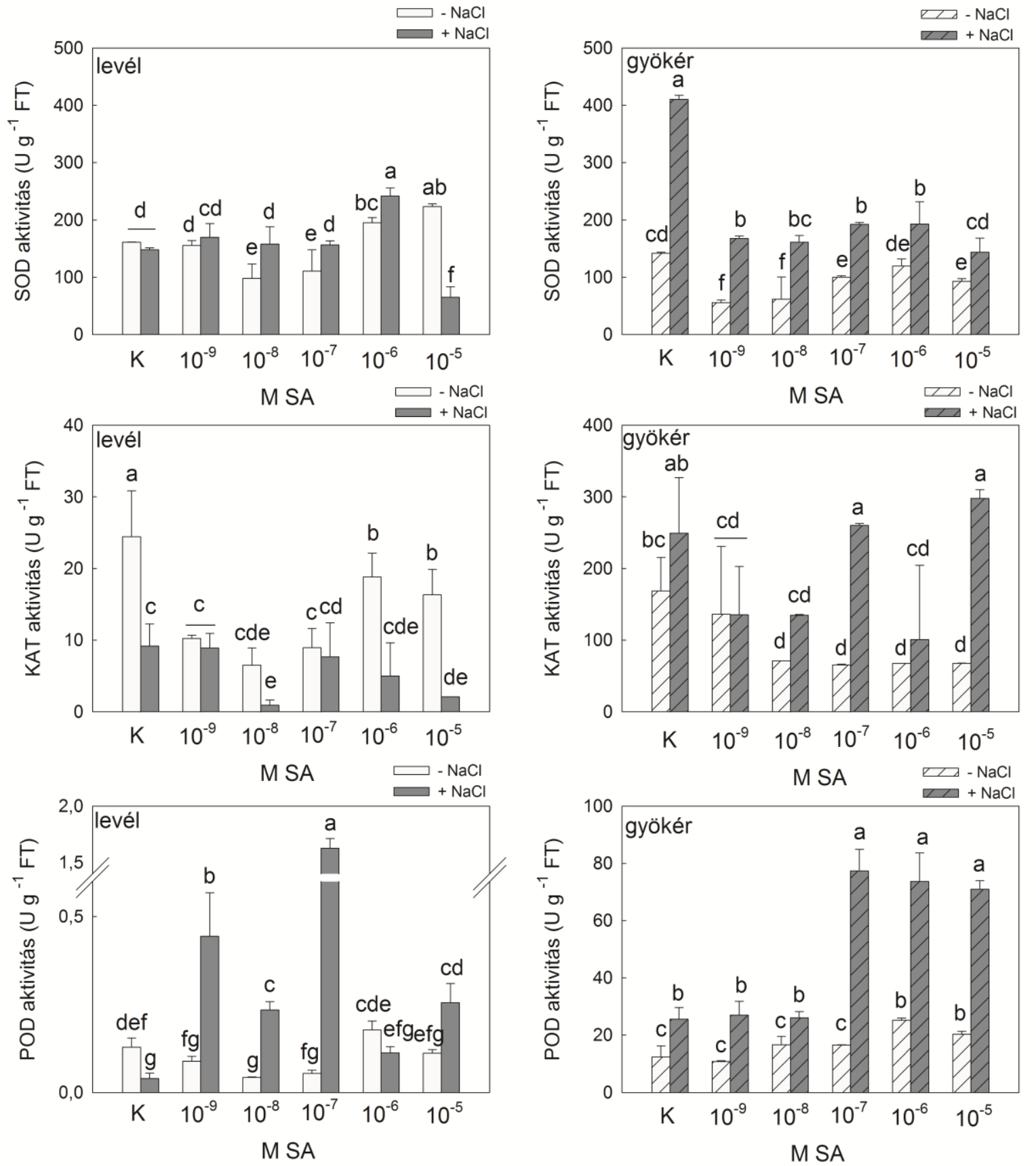

11. ábra: $10^{-9}-10^{-5} \mathrm{M}$ SA elökezelés hatása lúdfü növények levelének és gyökerének SOD, KAT és POD aktivitására 1 hetes, $100 \mathrm{mM} \mathrm{NaCl}$ kezelést követően (átlag $\pm \mathrm{SD}, \mathrm{n}=3$ ). Az x tengely feliratainak magyarázatát lásd a 8 . ábránál. A különböző betüvel jelölt oszlopok szignifikánsan különböznek egymástól $\mathrm{P} \leq 0,05$ valószínűségi szinten Duncan teszt alapján. 


\subsection{GST és GPOX aktivitásban bekövetkező változások lúdfü növényekben SA előkezelést követő sóstressz akklimatizáció során}

A GST enzim aktivitása koncentrációfüggő módon megemelkedett 3 hét SA előkezelés hatására lúdfü növények levelében és gyökerében. A GPOX aktivitása levélben szintén koncentrációfüggő módon nőtt, gyökérben viszont csak a legmagasabb, $10^{-5} \mathrm{M}$ SA kezelés hatására mutatott szignifikáns indukciót (12. ábra).
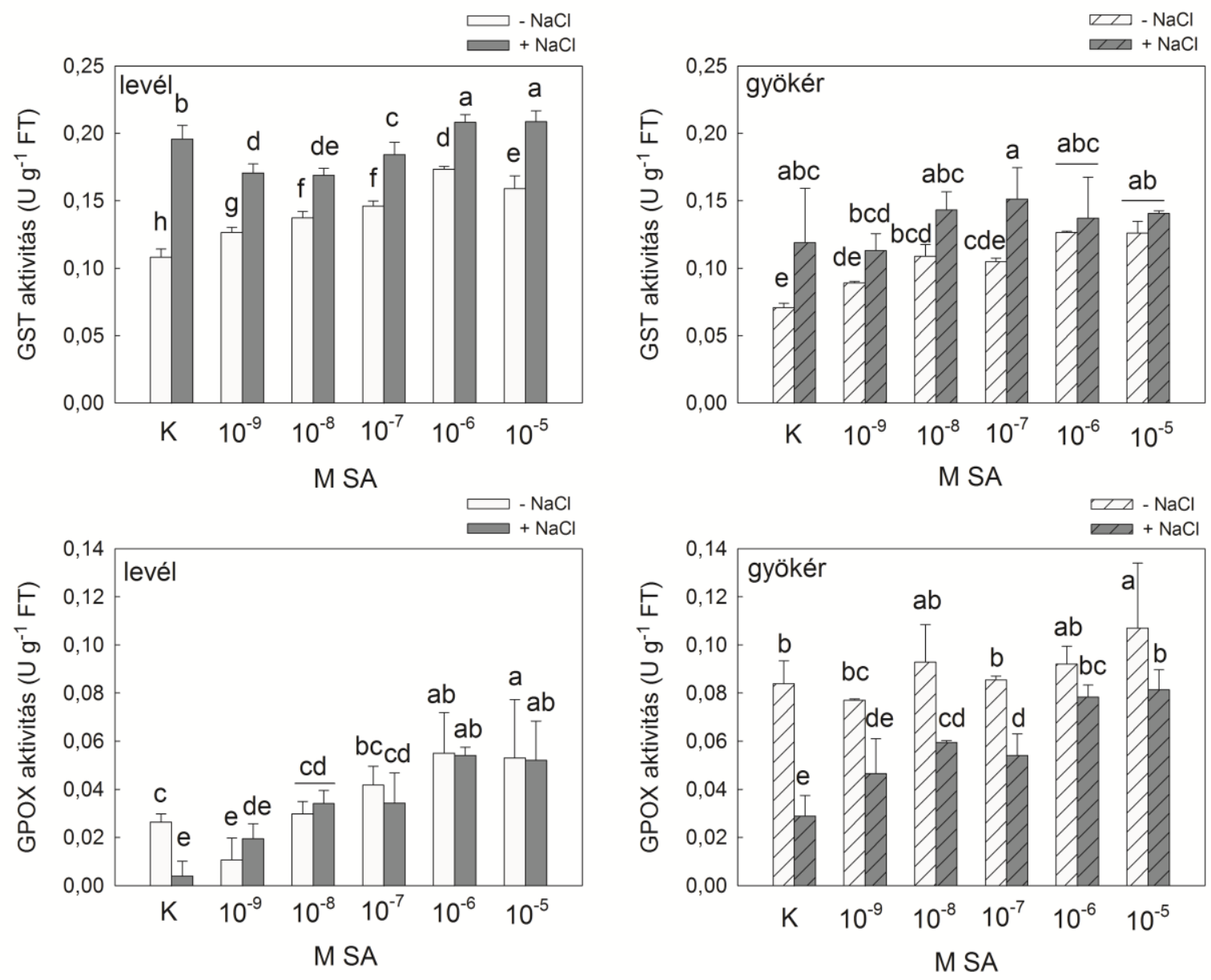

12. ábra: $10^{-9}-10^{-5} \mathrm{M}$ SA előkezelés hatása lúdfü növények levelének és gyökerének GST és GPOX aktivitására 1 hetes, $100 \mathrm{mM} \mathrm{NaCl}$ kezelést követően (átlag $\pm \mathrm{SD}, \mathrm{n}=3$ ). Az x tengely feliratainak magyarázatát lásd a 8 . ábránál. A különböző betüvel jelölt oszlopok szignifikánsan különböznek egymástól $\mathrm{P} \leq 0,05$ valószínüségi szinten Duncan teszt alapján.

Sókezelés hatására a GST aktivitása megemelkedett a kontrollhoz képest, azonban a GPOX aktivitása szignifikáns csökkenést mutatott mind levélben, mind gyökérben. SA elökezelés fokozta a GST aktivitásban bekövetkező emelkedést az egy hét sóstressz során és a $10^{-6}$ ill. 
$10^{-5} \mathrm{M}$ SA előkezelés hatására szignifikánsan magasabb volt a GST aktivitás a csak sókezelt kontrollhoz képest. A SA elökezelés levélben megakadályozta a sóstressz által indukált GPOX aktivitás csökkenését, $10^{-6}$ és $10^{-5} \mathrm{M}$ SA elökezelés pedig szignifikánsan megemelte a kezeletlen kontrollhoz képest a GPOX aktivitását sókezelés után is. Gyökérben a két legmagasabb SA koncentráció $\left(10^{-6}\right.$ és $10^{-5} \mathrm{M}$ SA) hatására kontroll szintü GPOX aktivitást mértünk egy hét sóstresszt követően (12. ábra).

\subsection{In silico promóter régió vizsgálat}

A kiválasztott lúdfü GST gének 5' szabályozó régiójában található cisz-ható elemek (cisacting elements) vizsgálatát in silico, a start kodon előtti 1500 bp felhasználásával végeztük el a PlantCARE adatbázis segítségével (Lescot és mtsai. 2002). Eredményeink alapján elmondhatjuk, hogy a SA-válaszban résztvevő TCA-elem, csak az AtGSTF8, AtGSTF9 és AtGSTU25 gének promóter régiójában volt jelen (4. melléklet). A védekezésben fontos elemek közül a TC-gazdag ismétlődések minden vizsgált szabályozó régióban megtalálható, viszont csak az AtGSTU19 és AtGSTU24 gének promóter régiójában volt jelen több (3-3) kópiában. A SAR-ban szerepet játszó TGACG-motívum szintén jelen volt minden vizsgált szabályozó régióban, legnagyobb számban az AtGSTF8, AtGSTF9 és AtGSTU25 gének promóterében. A vizsgált génszakaszokon számos más szabályozó elemet is azonosítottunk, köztük a szárazság indukálható MYB kötő helyet, az MBS motívumot, és az ABS indukálhatóságért felelös $A B R E$ elemet. A vizsgált $S l G S T$-k 5' upstream régiójában még számos fényválasz elem található, ami a különböző jelátviteli utak összetett kölcsönhatására utal. A vizsgált gének 5' régiójának főbb nukleotid motívumainak listája és a hozzájuk tartozó leírás a 4. mellékletben találhatóak.

\subsection{A kiválasztott AtGST gének expressziójában bekövetkező változások}

Irodalmi adatok alapján kiválasztottunk 3 tau (AtGSTU19, AtGSTU24 és AtGSTU25) és 2 phi (AtGSTF8 és AtGSTF9) csoportba tartozó GST gént, amelyek expressziós szintjét meghatároztuk $10^{-7}$ és $10^{-5} \mathrm{M} \mathrm{SA}$ előkezelést és $100 \mathrm{mM} \mathrm{NaCl}$ stresszt követően, hogy megvizsgáljuk az aktivitásban bekövetkezett változások hátterében állhatnak-e génexpressziós változások. Mindkét vizsgált SA koncentráció szignifikánsan megemelte az AtGSTU24 
expresszióját az előkezelés során hajtásban és gyökérben egyaránt, az AtGSTU19 gént viszont csak a $10^{-5}$ M SA előkezelés indukálta, a növények gyökerében (13. ábra).
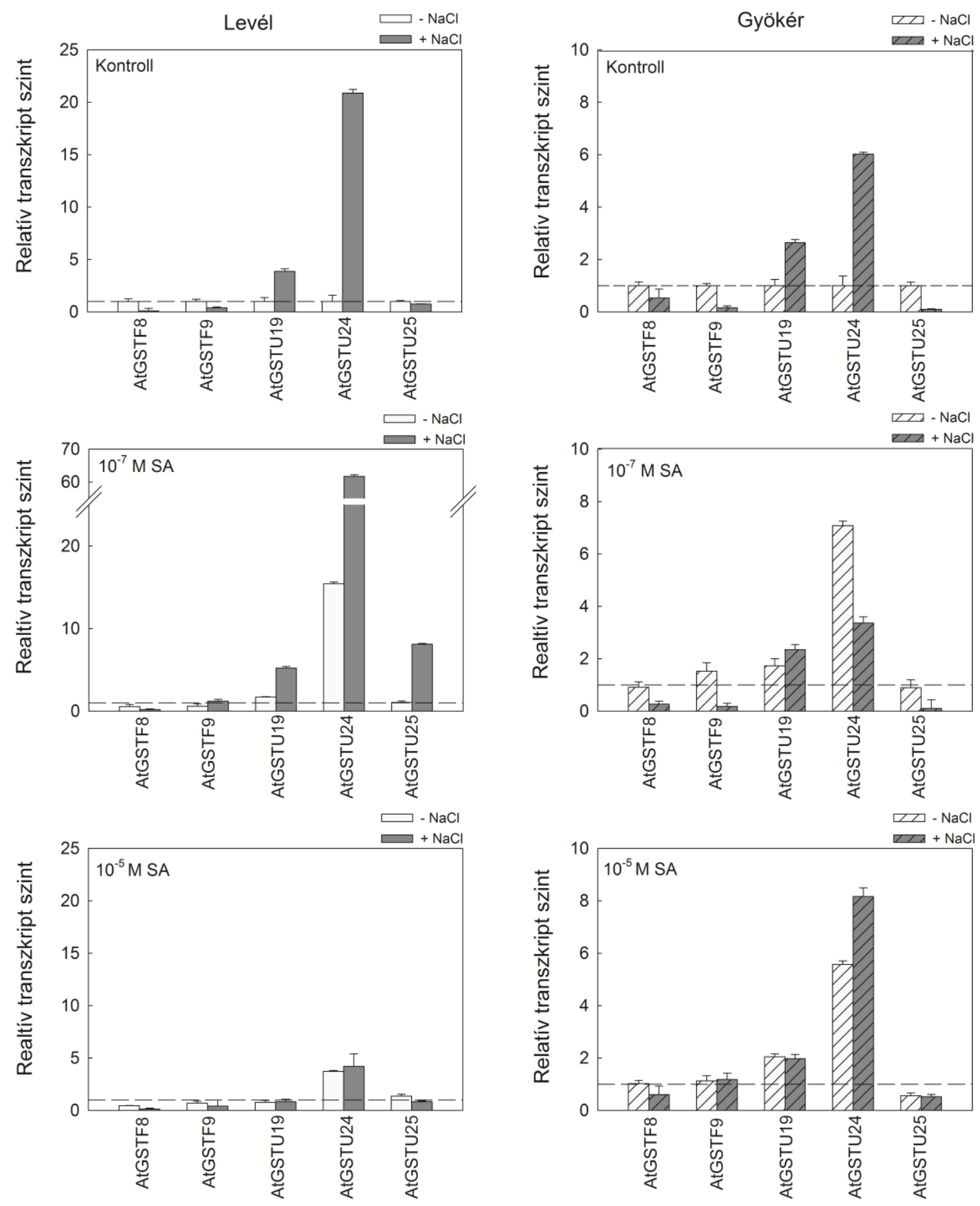

13. ábra: $10^{-7} \mathrm{M}$ és $10^{-5} \mathrm{M}$ SA elökezelés hatása lúdfü növények levelének és gyökerének GST transzkript szint változására 1 hetes, $100 \mathrm{mM} \mathrm{NaCl}$ kezelést követően (átlag $\pm \mathrm{SD}, \mathrm{n}=3$ ). (- $\mathrm{NaCl}$ : nem sókezelt minták, $+\mathrm{NaCl}: 100 \mathrm{mM} \mathrm{NaCl}-$ dal kiváltott sóstressznek kitett növények). A transzkript szint relatív egysége minden gén esetében a hajtás vagy gyökér kontroll mintáiban mért relatív transzkript szint $(=1)$, amelyet szaggatott vonal jelöl az ábrákon. 
Sóstressz során az AtGSTF8, AtGSTF9 és AtGSTU25 gének represszálódtak, viszont indukálódott az AtGSTU19 és AtGSTU24 gének expressziója. A $10^{-7}$ M SA elökezelés fokozta az AtGSTU19 és AtGSTU24 gének kifejeződését levélben, gyökérben viszont a sókezelt kontrollban mérhető szintek alatt maradt a gének expressziója. A magasabb koncentrációjú $\left(10^{-5} \mathrm{M}\right)$ SA elökezelés hatására levélben az AtGSTU24, gyökérben az AtGSTU19 örizte meg magasabb expresszáltsági szintjét, azonban további indukció nem volt megfigyelhető a sókezelés hatására. Gyökérben az AtGSTU24 expressziója csökkent a sóstressznek kitett $10^{-7}$ M SA előkezelt növényekben, de így is 3-szoros indukciót mutatott a kísérlet végén (13. ábra).

\subsection{GST gének mutációjának hatása a lúdfü csíranövények GST aktivitására, életképességére és gyökérnövekedésére}

Rövidtávú kísérletekben a 2 hetes vad típusú és GST mutáns (Atgstu19 és Atgstf9) lúdfü növények életképessége különböző módon reagált 48 óra magas só- $(150 \mathrm{mM})$ és SA $\left(10^{-5} \mathrm{M}\right.$ SA) kezelésekre. Sóstressz során lecsökkent a növények életképessége, azonban a mutánsokban nagyobb mértékü volt a csökkenés. A vad típusban 60-70\%-os volt az életképesség csökkenés, az Atgstu19 és Atgstf9 mutánsokban viszont 80-90\%-os életképesség vesztést figyelhettünk meg. Ehhez képest a $10^{-5} \mathrm{M}$ SA kezelés kisebb mértékben befolyásolta az életképességet. Sziklevélben a vad típusú és a mutáns növények hasonló változást mutattak a kezelés hatására, viszont gyökérben az Atgstu19 mutánsban mintegy 60\%-kal csökkent az életképesség, amíg a vad típusban mindössze10\%-kal (14. ábra).

A mutáns növények GST aktivitása a vad típushoz képest már kontroll állapotban is szignifikánsan alacsonyabb volt. Sóstressz és SA kezelés hatására a vad típusú és az Atgstf9 mutánsokban a GST aktivitás megemelkedett, az Atgstu19 növényekben viszont szignifikánsan alacsonyabb maradt az alkalmazott kezelés után a vad típushoz viszonyítva (15. ábra). 

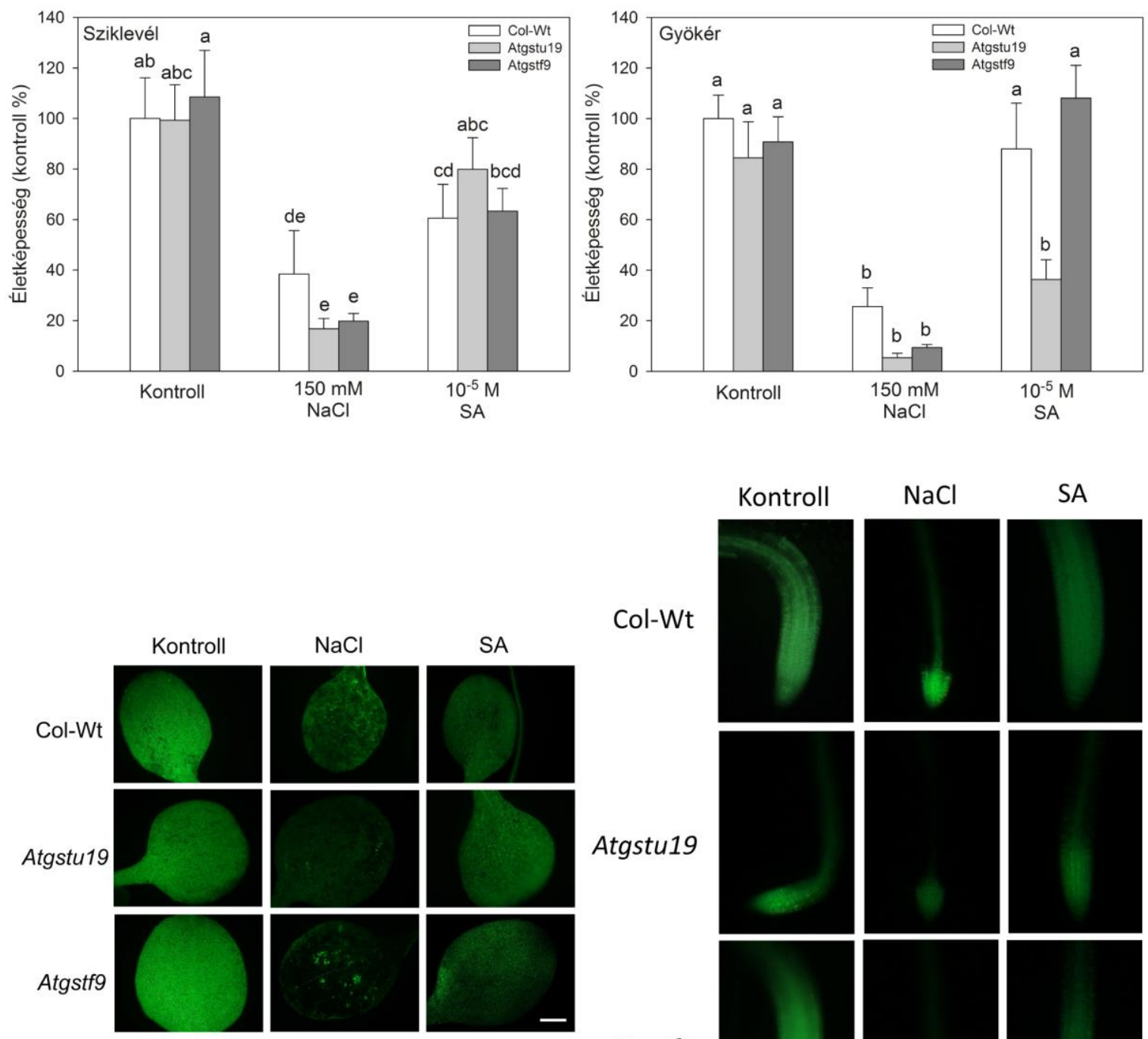

Col-Wt
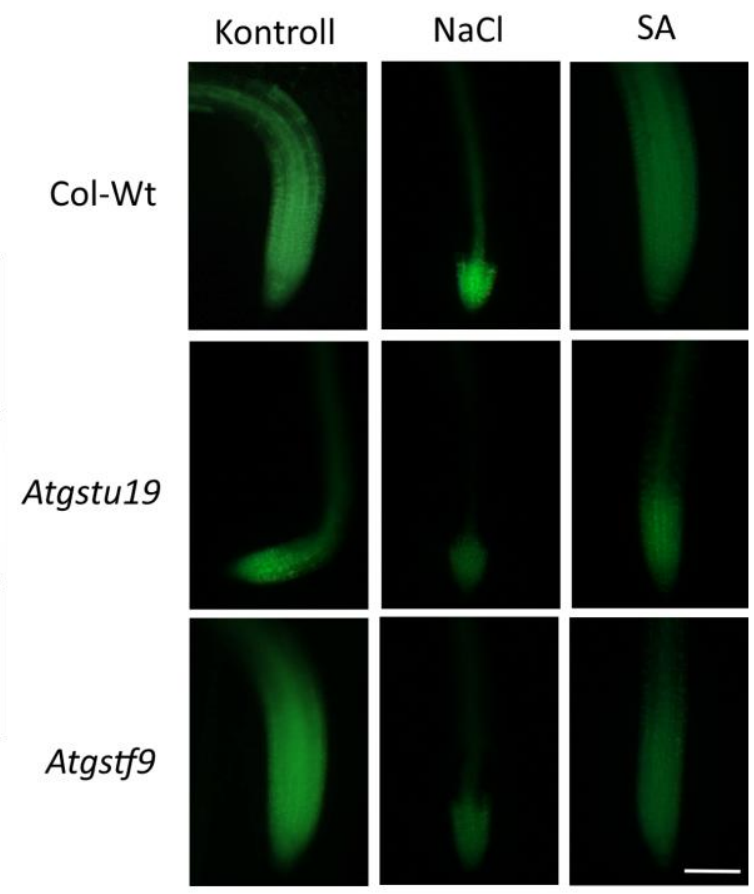

SA

14. ábra: $\mathrm{NaCl}(150 \mathrm{mM})$ és $\mathrm{SA}\left(10^{-5} \mathrm{M}\right)$ kezelés hatása két hetes vad típusú (Col-Wt) és GST mutáns (Atgstu19 és Atgstf9) lúdfü növények sziklevelének és gyökerének életképességére $48 \mathrm{~h}$ kezelést követően (átlag $\pm \mathrm{SE}, \mathrm{n}=10$ ). Az életképesség meghatározása FDA festéssel történt. A: a mért fluoreszcencia értékek a kontroll \%-ban kifejezve B: Reprezentatív fotók fluoreszcein diacetáttal jelölt kontroll, SA és $\mathrm{NaCl}$ kezelt vad típusú Arabidopsis szikleveléről (mérce $=0,5 \mathrm{~mm}$ ) és fögyökércsúcsáról (mérce=0,1 $\mathrm{mm}$ ). A különböző betüvel jelölt oszlopok szignifikánsan különböznek egymástól $\mathrm{P} \leq 0,05$ valószínűségi szinten Duncan teszt alapján.

Megvizsgáltuk a növények növekedését 2 hét $150 \mathrm{mM} \mathrm{NaCl}$ és $10^{-5} \mathrm{M}$ SA kezelés alatt. A növényeket 4 napos korukban helyeztük a kezelésre és vertikális táptalajon nevelve vizsgáltuk 
a gyökérnövekedésüket. Az eredmények alapján elmondhatjuk, hogy az Atgstf9 mutánsoknak már kontroll körülmények között is lecsökkent a gyökérnövekedése a vad típushoz és az Atgstu19 mutánshoz képest. $150 \mathrm{mM} \mathrm{NaCl}$ kezelés gátolta a gyökérnövekedést vad típusban, de a mutánsokban kifejezettebb volt ez a gátlás. A $10^{-5} \mathrm{M}$ SA kezelés hatására hasonló mértékben csökkent a gyökérhossz a vad típusú és mutáns növényekben (16. ábra).

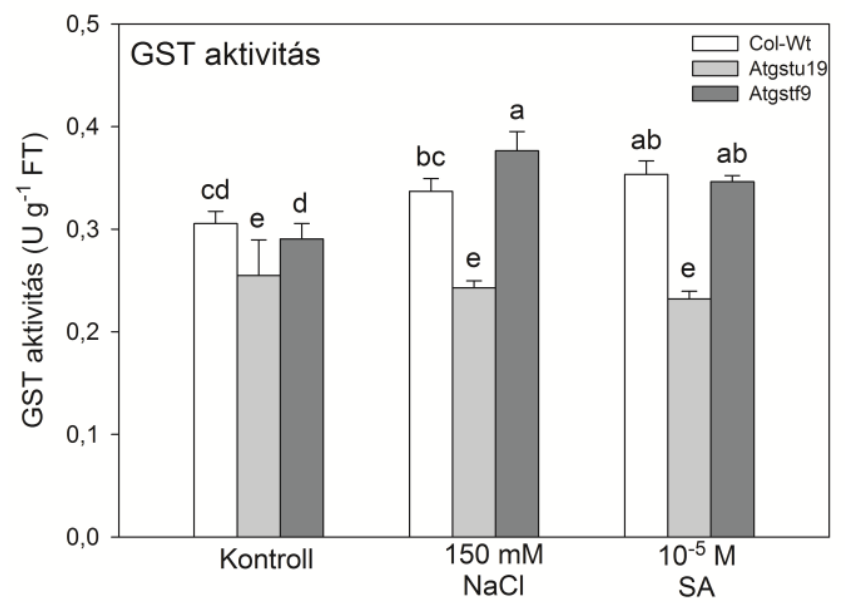

15. ábra: $\mathrm{NaCl}(150 \mathrm{mM})$ és $\mathrm{SA}\left(10^{-5} \mathrm{M}\right)$ kezelés hatása két hetes vad típusú $(\mathrm{Col}-\mathrm{Wt})$ és GST mutáns (Atgstu19 és Atgstf9) lúdfü növények GST aktivitására 48 h kezelést követően (átlag $\pm \mathrm{SD}, \mathrm{n}=3$ ). A különböző betűvel jelölt oszlopok szignifikánsan különböznek egymástól $\mathrm{P} \leq 0,05$ valószínüségi szinten Duncan teszt alapján.

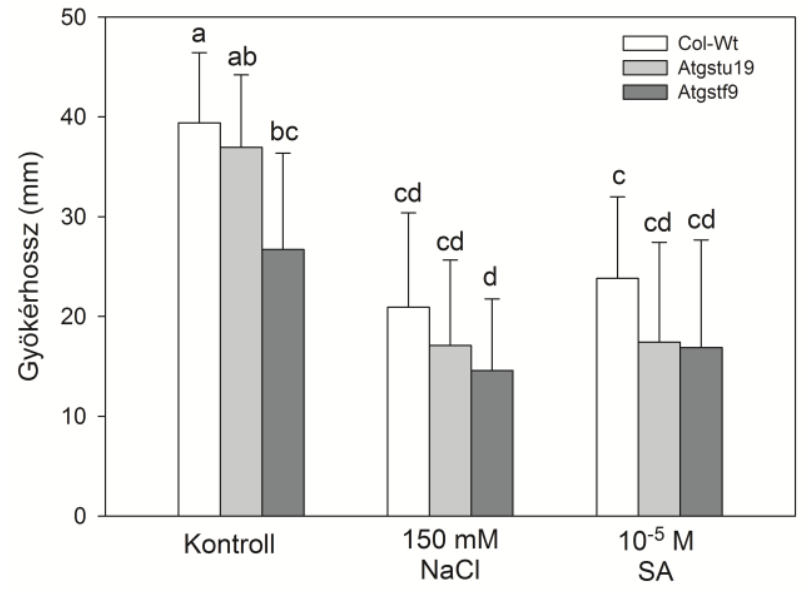

16. ábra: A vad típusú (Col-Wt) és GST mutáns (Atgstu19 és Atgstf9) lúdfü növények gyökérhossza 2 hét $150 \mathrm{mM} \mathrm{NaCl}$ vagy $10^{-5} \mathrm{M}$ SA kezelés után (átlag $\pm \mathrm{SD}, \mathrm{n}=8$ ). A különböző betüvel jelölt oszlopok szignifikánsan különböznek egymástól $\mathrm{P} \leq 0,05$ valószínűségi szinten Duncan teszt alapján. 


\subsection{Paradicsom növények növekedésében bekövetkező változások SA elökezelés hatására sóstressz akklimatizáció során}

A hidropónikus kultúrában nőtt 4 hetes paradicsom növényekben 4 hét $10^{-4} \mathrm{M}$ SA kezelés csökkentette a gyökér- és a hajtás növekedését, habár utóbbit nem szignifikánsan. Sóstressz hatására lecsökkent a hajtás- és gyökérhossz, azonban egyik változás sem volt szignifikáns a kontroll növényekhez viszonyítva. A 3 hetes SA elökezelést követően alkalmazott sókezelés a növények hajtáshosszát kis mértékben csökkentette. A $10^{-7} \mathrm{M}$ SA-val elökezelt növények gyökérhossza a sóstressz hatására szignifikánsan csökkent, viszont $10^{-4} \mathrm{M}$ SA előkezelés hatására további gyökérhossz csökkenés nem volt megfigyelhető $100 \mathrm{mM} \mathrm{NaCl}$ hatására (17. ábra).
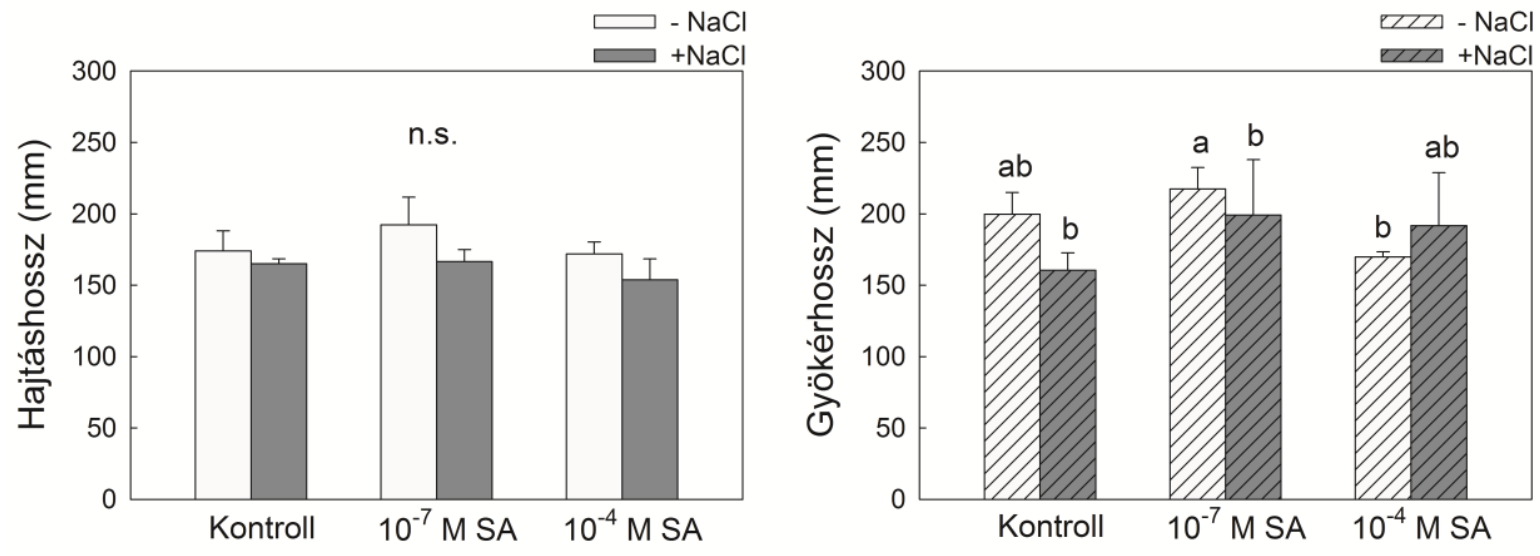

17. ábra: Három hét $10^{-7} \mathrm{M}$ és $10^{-4} \mathrm{M} \mathrm{SA}$ előkezelés hatása paradicsom növények hajtás- és gyökérhosszára 1 hetes, $100 \mathrm{mM} \mathrm{NaCl}$ kezelést követően (átlag $\pm \mathrm{SD}, \mathrm{n}=4)$. ( $\mathrm{NaCl}$ : nem sókezelt minták; $+\mathrm{NaCl}: 100 \mathrm{mM} \mathrm{NaCl}-$ dal kiváltott sóstressznek kitett növények). A különböző betüvel jelölt oszlopok szignifikánsan különböznek egymástól $\mathrm{P} \leq 0,05$ valószínüségi szinten Duncan teszt alapján.

\subsection{SA előkezelés hatása paradicsom növények $\mathrm{H}_{2} \mathrm{O}_{2}$ tartalmára sóstressz során}

A SA kezelés a növények hajtásában nem okozott jelentős $\mathrm{H}_{2} \mathrm{O}_{2}$ szint változást, viszont a gyökerükben szignifikáns változásokat indukált. A $10^{-7} \mathrm{M}$ SA előkezelés hatására megemelkedett, a $10^{-4} \mathrm{M}$ SA hatására viszont lecsökkent a gyökér $\mathrm{H}_{2} \mathrm{O}_{2}$ tartalma. Egy hét sókezelést követően a hajtás $\mathrm{H}_{2} \mathrm{O}_{2}$ tartalma megemelkedett, a gyökéré viszont lecsökkent. Hajtásban a SA előkezelt mintákban is magasabb $\mathrm{H}_{2} \mathrm{O}_{2}$ szintet mértünk az egy hét sóstresszt követően, viszont ez nem érte el a sókezelt kontrollban mérhető szintet. Gyökérben a $10^{-7} \mathrm{M}$ 
SA előkezelés hatására a mintákban $\mathrm{H}_{2} \mathrm{O}_{2}$ tartalom csökkenést detektáltunk, ennek mértéke a csak sókezelt növényekben mért alatt maradt. Gyökérben a $10^{-4} \mathrm{M}$ SA előkezelést követő egy hét sókezelés során nem tapasztaltunk a $\mathrm{H}_{2} \mathrm{O}_{2}$ tartalomban változást (18. ábra).
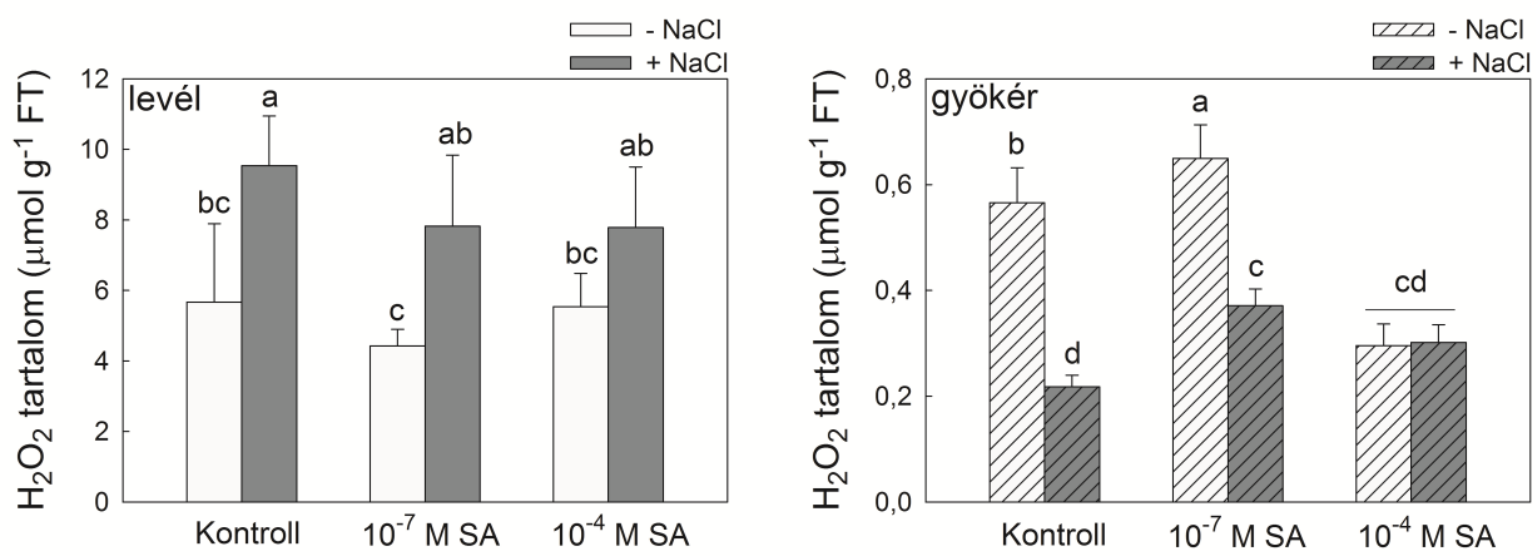

18. ábra: Három hét $10^{-7} \mathrm{M}$ és $10^{-4} \mathrm{M}$ SA előkezelés hatása paradicsom növények levelének és gyökerének $\mathrm{H}_{2} \mathrm{O}_{2}$ szint változására 1 hetes, $100 \mathrm{mM} \mathrm{NaCl}$ kezelést követően (átlag $\pm \mathrm{SD}$, $\mathrm{n}=3$ ). (- $\mathrm{NaCl}$ : nem sókezelt minták; + NaCl: $100 \mathrm{mM} \mathrm{NaCl}$ - dal kiváltott sóstressznek kitett növények). A különböző betüvel jelölt oszlopok szignifikánsan különböznek egymástól $\mathrm{P} \leq 0,05$ valószínüségi szinten Duncan teszt alapján.

\subsection{Paradicsom növények levelének és gyökerének GST, GPOX és DHAR aktivitása SA előkezelést követő sóstressz akklimatizáció során}

Vizsgáltuk a SA- és só-indukálta változásokat a GST, GPOX és DHAR aktivitásokban 8 hetes paradicsom növények levelében és gyökerében, $10^{-7}$ és $10^{-4} \mathrm{M}$ SA elökezelést és egy hét sóstresszt követően. A CDNB szubsztráttal szemben mérhetö össz GST aktivitás paradicsom növények levelében és gyökerében a 4 hetes SA kezelés után kontroll szinten volt. A CHP szubsztráttal szembeni GPOX aktivitás szignifikánsan megemelkedett gyökérben mindkét alkalmazott SA előkezelés hatására. Paradicsom növények levelében $10^{-7} \mathrm{M} \mathrm{SA}$ előkezelés hatására nőtt, $10^{-4} \mathrm{M}$ SA előkezelés viszont csökkentette a GPOX aktvitást. A sóstressz szignifikánsan növelte a GST és GPOX aktivitást levélben és gyökérben a kontrollhoz viszonyítva. A SA elökezelés hatására a GST aktivitása nagyobb mértékü növekedést mutatott, a csak sókezelt növényekhez képest is. A legmagasabb GST aktivitást a $10^{-4} \mathrm{M} \mathrm{SA}$ elökezelést kapott növények gyökerében mértük. A SA előkezelt növényekben sókezelés hatására a GPOX aktivitás megemelkedett és a sókezelt kontrolléhoz hasonló vagy attól 
magasabb GPOX aktivitást mutatott, kivételt képez a $10^{-7} \mathrm{M}$ SA-elökezelt növények gyökere, amelynek GPOX aktivitása csökkent az egy hét sóstressz után (19. ábra).
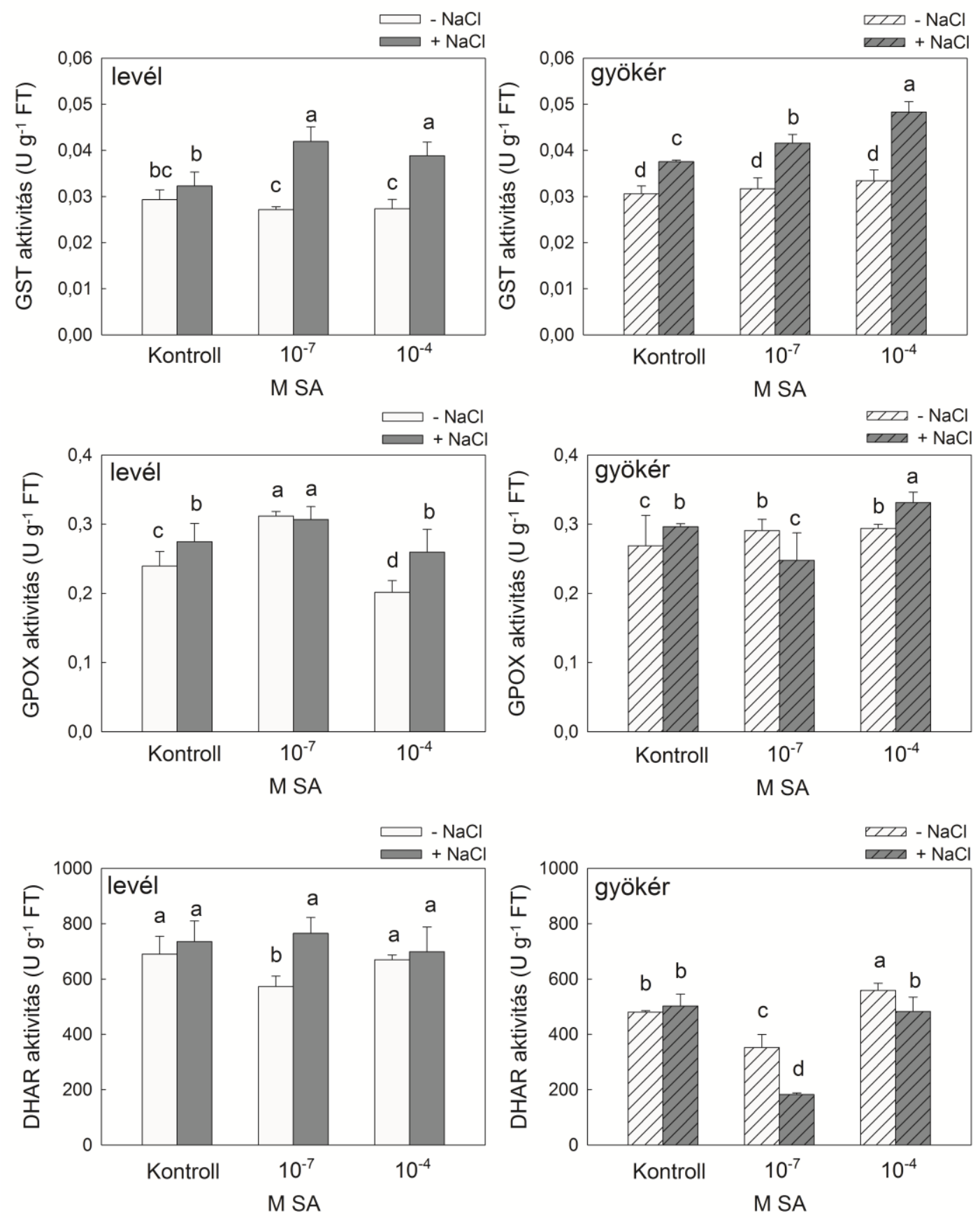

19. ábra: Három hét $10^{-7} \mathrm{M}$ és $10^{-4} \mathrm{M}$ SA elökezelés hatása paradicsom növények levelének és gyökerének GST, GPOX és DHAR aktivitásában bekövetkező változására 1 hetes, $100 \mathrm{mM} \mathrm{NaCl}$ kezelést követően (átlag $\pm \mathrm{SD}, \mathrm{n}=3$ ). (- $\mathrm{NaCl}$ : nem sókezelt minták; + $\mathrm{NaCl}$ : 100 $\mathrm{mM} \mathrm{NaCl}$ - dal kiváltott sóstressznek kitett növények). A különböző betüvel jelölt oszlopok szignifikánsan különböznek egymástól $\mathrm{P} \leq 0,05$ valószínüségi szinten Duncan teszt alapján. 
A DHAR aktivitása, amely az aszkorbát regenerálásában betöltött szerepe által szintén befolyásolhatja a redox állapotot, nem változott szignifikánsan a növények levelében SA kezelés és sóstressz után sem. Kivételt képez a $10^{-7} \mathrm{M}$ SA kezelés, amely hatására levélben és gyökérben is lecsökkent a DHAR aktivitás, ami a gyökérben a sóstressz hatására még inkább megnyilvánult. A $10^{-4} \mathrm{M}$ SA kezelés azonban kontroll szinten tartotta vagy megemelte a DHAR enzim aktivitását az előkezelés során és sóstresszt követően is.

\subsection{Paradicsomban található GST gének filogenetikai csoportosítása és génexpressziójuk vizsgálata SA előkezelés és sóstressz során}

A paradicsom glutation transzferáz kódoló szekvenciákat in silico módon azonosítottuk a Sol Genomics Network adatbázisban (Bombarely és mtsai. 2011). Létrehoztunk egy homológián alapuló családfát az SGN adatbázisában található szekvenciák mintegy 200 aminosav hosszúságú szakaszát felhasználva a MEGA5 programmal (Tamura és mtsai. 2011). A paradicsomban található GST szekvenciákat 8 szolubilis csoportba soroltuk a már ismert AtGST szekvenciákkal való hasonlóság és a GST protein szekvenciák ismert konzervatív régiói (Edwards és mtsai. 2002) segítségével. Az SGN adatbázisban 81 teljes vagy részleges paradicsom GST szekvenciát azonosítottunk. Ezek közül a tau (SlGSTU-k) csoportba 56 gén tartozik és ez a csoport a legnagyobb, a phi (SIGSTF) és lambda (S1GSTL) csoportokba 5-5 szekvenciát soroltunk, a DHAR 6, a théta (SIGSTT) 4 és a zéta (SIGSTZ) 2 GST gént tartalmaz. Ezen kívül a paradicsom genom tartalmaz egy tetraklórhidrokinon dehalogenáz (SITCHQD) szekvenciát, valamint megtalálható benne egy, az eukarióta elongációs faktor 1B $\gamma$-alegységek csoportjába tartozó GST (SIEF1B $\gamma$ ) és egy membránkapcsolt GST is (SIMGST). A rokonsági fa nem tartalmaz három olyan szekvenciát (Solyc06g083770.2.1, Solyc09g009820.2.1 és Solyc12g036560.1.1), amelyekben csak egy tioredoxin-szerü domén található, ami a GSH kötésben vehet részt (Dixon és Edwards 2010). Annak érdekében, hogy a különböző elnevezésekből eredő félreértéseket a továbbiakban elkerüljük, az SGN adatbázisában található GST szekvenciákat elneveztük, az Edwards és mtsai. (2000) által javasolt szabályok alapján. A paradicsom genomjának feltérképezése lehetővé tette, hogy a GST szekvenciák elrendeződését és helyét meghatározzák a kromoszómákon belül. Az elnevezésük csoportonként történt úgy, hogy a szekvenciák számozását az egyes kromoszómán lévővel kezdtük és folytatólagosan számoztuk (20. ábra). 


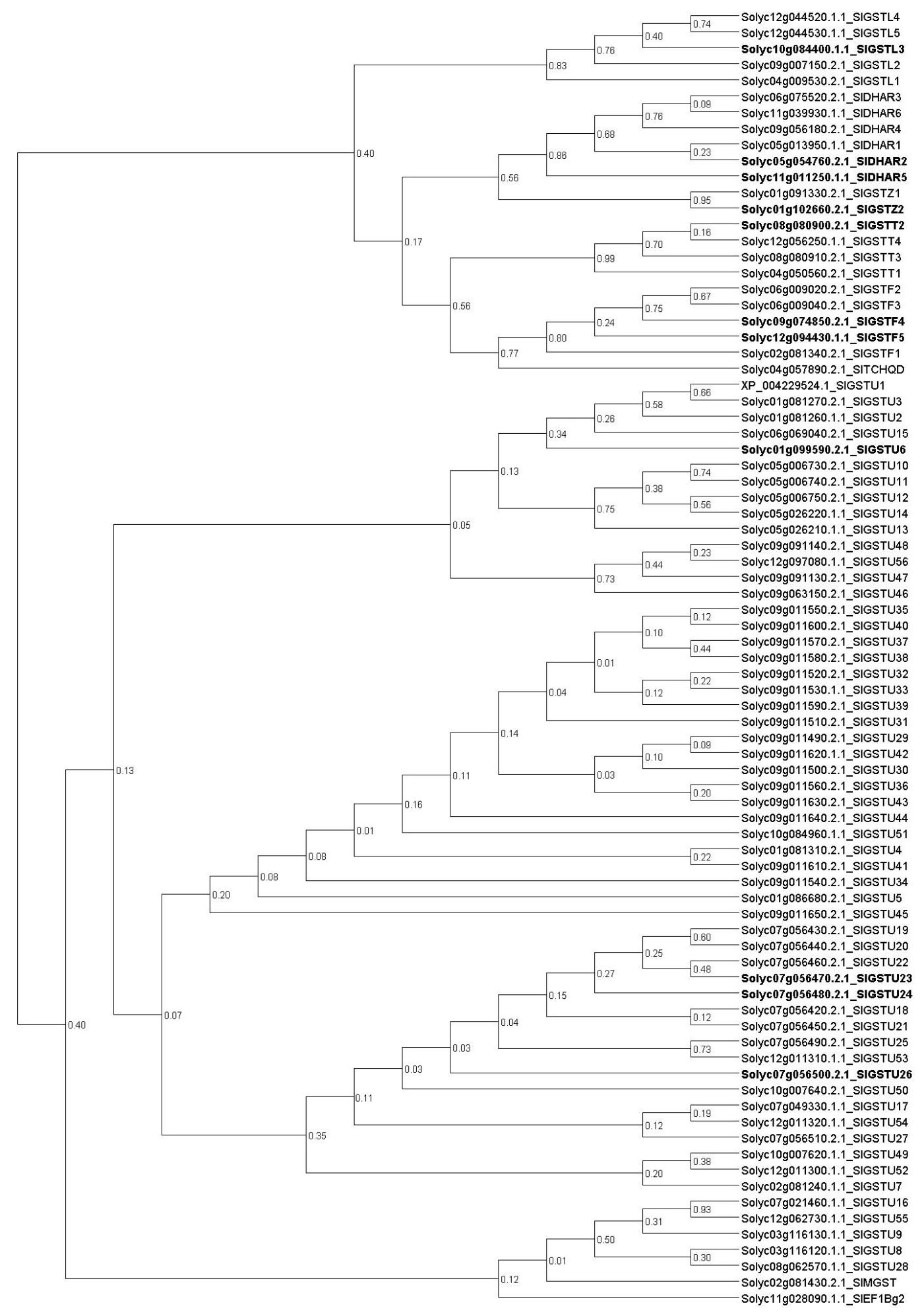

20. ábra: Rokonsági fa (filogram) a paradicsom ismert GST szekvenciáiból. A rokonsági fán az SGN adatbázisban található szekvenciák azonosítási számai láthatóak egy szekvencia kivételével, amelyet az NCBI adatbázisban található szekvencia azonosítóval jelöltünk. A szekvenciákat Edwards és mtsai. (2000) által meghatározott nevezéktani szabályok alapján neveztük el és az ábrán félkövér betüvel jelöltük az általunk vizsgált gének nevét. 
A kiválasztott 11 GST szekvencia transzkripciós szintjét QRT-PCR módszerrel vizsgáltuk 8 hetes paradicsom növényekben, egy hét sókezelés után a kontroll vagy SA előkezelt növényekben. Annak érdekében, hogy az egyes GST-k transzkripciós szintjében bekövetkező változásokat össze tudjuk hasonlítani, a relatív transzkript mennyiséget a kontroll minták levelében és gyökerében génenként egynek vettük. Az alkalmazott sókezelés (100 mM NaCl) egy hét kezelés után indukálta néhány GST transzkripcióját. Levélben megemelkedett a tau csoportba tartozó (SlGSTU23 és SlGSTU26) GST-k expressziós szintje, gyökérben pedig az SlGSTT2, SlGSTZ2, SIDHAR5 és SlGSTL3 mutattak indukciót sóstressz során. A 4 hetes SA kezelés koncentrációfüggő módon hatott a vizsgált paradicsom GST-k génexpressziójára. $10^{-7}$ M SA jelenlétében a levelekben az SlGSTF4 és SlGSTU24 szekvenciák transzkripciós szintjében kétszeres növekedést mértünk, gyökérben ugyanez a kezelés négyszeresére emelte az SlGSTF4 és kétszeresére az SlGSTU23, SlGSTU26, SlGSTZ2, SlGSTT2 és SlGSTL3 expresszióját. A $10^{-4} \mathrm{M}$ SA előkezelés több vizsgált GST szekvencia expresszióját növelte a $10^{-7}$ M SA kezeléshez viszonyítva és az adott génekben 2-6-szoros indukciót detektáltunk, föként az SlGSTF4, SlGSTU23 és SlGSTL3 gének esetében. A SA-val történő előkezelés koncentrációfüggő módon váltja ki a „priming” hatást (Gémes és mtsai. 2011, Poór és mtsai. 2011). A SA kísérleteinkben is enyhítette a sóstressz okozta károsodást és a magasabb koncentráció, $10^{-4} \mathrm{M}$ SA hatására kifejezettebb változások voltak a $G S T$ génexpresszió mintázatában. Egy phi csoportba tartozó GST (SlGSTF4) transzkript szintje mutatott szignifikáns emelkedést levélben és gyökérben is a kontrollhoz képest a SA kezelés hatására. Általánosságban elmondható, hogy levélben a phi és tau (SlGSTU6, SlGSTU26) csoportú GST-k expressziója $\mathrm{NaCl}$ és SA kezelés hatására egyaránt indukálódott, amíg az SIGSTT2, SIGSTZ2, SIDHAR5 és SIGSTL3 transzkripciója a gyökérben mutatott magasabb expresszáltsági szintet azt jelezve, hogy ezek a gének fontos szerepet játszanak az általunk tanulmányozott stresszfolyamatban és hozzájárulhatnak a mért GST aktivitás emelkedéséhez. A $100 \mathrm{mM} \mathrm{NaCl}$ kezelés a $10^{-4} \mathrm{M}$ SA elökezelt növényekben a transzkripciós szint csökkenését idézte elő néhány vizsgált SlGST szekvencia, mint pl. az SlGSTU24 esetében (21. ábra). 

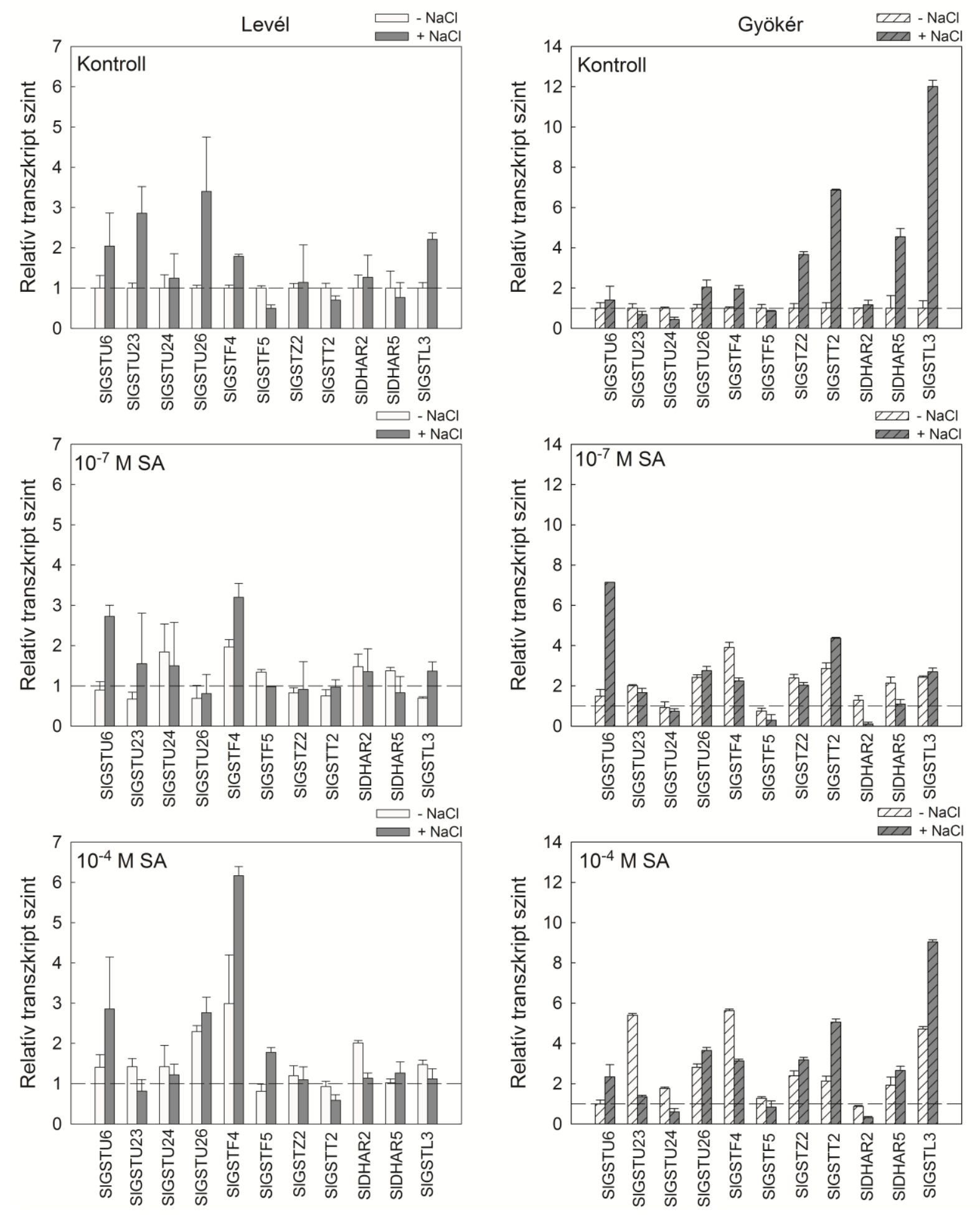

21. ábra: Három hét $10^{-7} \mathrm{M}$ és $10^{-4} \mathrm{M}$ SA előkezelés hatása paradicsom növények levelének és gyökerének GST transzkript szint változására 1 hetes, $100 \mathrm{mM} \mathrm{NaCl}$ kezelést követően (átlag $\pm \mathrm{SD}, \mathrm{n}=3$ ). (- $\mathrm{NaCl}$ : nem sókezelt minták; $+\mathrm{NaCl}: 100 \mathrm{mM} \mathrm{NaCl}-$ dal kiváltott sóstressznek kitett növények). A transzkript mennyisége relatív egysége a hajtás vagy gyökér kontroll mintáiban mért relatív transzkript szint $(=1)$, amelyet szaggatott vonal jelöl az ábrákon. 


\subsection{Promóter régió in silico vizsgálata}

A paradicsom genom szekvenciájának közzététele megkönnyítette a cisz-szabályozó elemek hozzáférését az SGN adatbázisában (http://solgenomics.net), így a kiválasztott paradicsom GST gének cisz-ható elemeit a start kodon elötti 1500 bp felhasználásával, a lúdfühöz hasonlóan, a PlantCARE adatbázis segítségével (Lescot és mtsai. 2002) in silico vizsgáltuk. A SA-válaszban résztvevő TCA-elem csak a SIGSTU6, SIGSTT2 és SIGSTZ2 gének promóter régiójában volt jelen több példányban. Azonban más, védekezésben fontos elemek (TCgazdag ismétlődések) az SlGSTT2 promóter régió kivételével, megtalálhatóak minden vizsgált szabályozó régióban, általában több kópiában. A vizsgált génszakaszokon azonosítottuk a TGACG elemet, az MBS motívumot és az ABRE elemet. Ezek mellett a flavonoid bioszintézis gének szabályozásában fontos MBSII elem is megtalálható volt néhány gén promóterében. A vizsgált SlGST-k 5' upstream régiója a lúdfühöz hasonlóan számos fényválasz elemet tartalmaz, így valószínüleg a jelátviteli utak összetett kölcsönhatása ezekre a génekre is kihatással van. A vizsgált gének 5' régiójának főbb cisz-ható elemek listája és a hozzájuk tartozó leírás az 5. mellékletben találhatóak.

\subsection{AO aktivitás SA előkezelt és sóstressznek kitett paradicsom növényekben}

Az aldehid oxidáz (AO) aktivitását natív PAGE gélben történő elválasztás után 2-naftaldehid (NAld) szubsztráttal határoztuk meg. A legkisebb mobilitású AO sávot (AO1) levél és gyökér szövetben is detektáltuk, így a továbbiakban ennek az aktivitását vizsgáltuk. Gyökérben legalább 4, nagyobb mobilitású sáv is detektálható volt, azonban ezek aktivitása alacsony volt és a gélen csak nagyon gyenge jelet adtak. Paradicsom növények levelében a 4 hetes, $10^{-7} \mathrm{M}$ SA előkezelés hatására lecsökkent a legkisebb mobilitású AO sáv aktivitása, $10^{-4} \mathrm{M} \mathrm{SA}$ előkezelés viszont kontroll szintű AO aktivitást eredményezett a levelekben. Gyökérben az SA előkezelés nem okozott szignifikáns eltérést az AO aktivitásában a kontrollhoz viszonyítva. Sóstressz hatására az AO aktivitása lecsökkent a kontroll és a SA előkezelt növényekben egyaránt, kivételt képez a $10^{-7} \mathrm{M}$ SA elökezelés, amely növelte az AO aktivitását egy hét $100 \mathrm{mM} \mathrm{NaCl}$ kezelés után (22. ábra). 

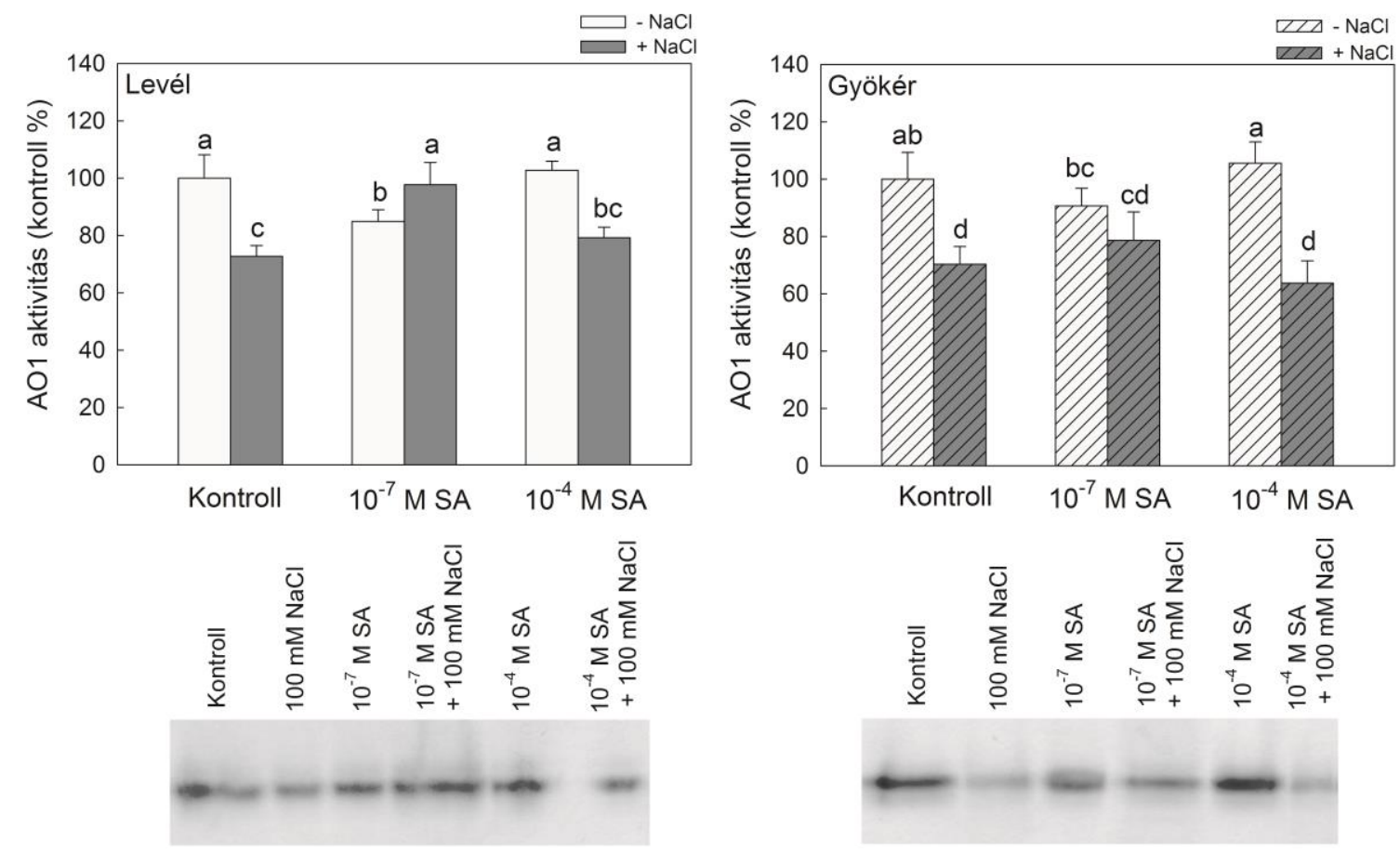

22. ábra: Három hét $10^{-7} \mathrm{M}$ és $10^{-4} \mathrm{M}$ SA előkezelés hatása paradicsom növények levelének és gyökerének $\mathrm{AO} 1$ aktivitására 1 hetes, $100 \mathrm{mM} \mathrm{NaCl}$ kezelést követően (átlag $\pm \mathrm{SD}, \mathrm{n}=3$ ). $\mathrm{A}$ diagramok a gélek AO1 sávjának számszerüsített adatait tartalmazzák. A keletkező színreakció kvantifikálását KODAK EDAS rendszer segítségével végeztük. A diagramok alatt a natív PAGE gélekről készült reprezentatív fotók láthatók. (- $\mathrm{NaCl}$ : nem sókezelt minták; + NaCl: $100 \mathrm{mM} \mathrm{NaCl}$ - dal kiváltott sóstressznek kitett növények). A különböző betűvel jelölt oszlopok szignifikánsan különböznek egymástól $\mathrm{P} \leq 0,05$ valószínüségi szinten Duncan teszt alapján.

\subsection{ABS bioszintézis gének expressziója SA előkezelés és sóstressz során paradicsom növények levelében és gyökerében}

Létrehoztunk egy, a szekvenciák hasonlóságán alapuló családfát az ismert paradicsom és lúdfü 9-cisz-epoxikarotinoid dioxigenázok (9-cis-epoxycarotenoid dioxygenase, NCED) és karotinoid hasító dioxigenázok (çarotenoid cleavage dioxygenase, CCD) felhasználásával, hogy megvizsgáljuk a génszekvenciák kapcsolatát. Három paradicsom és 5 lúdfü NCED szekvencia található az SGN és TAIR adatbázisokban, amelyek közül a filogram alapján az SINCED1 (Solyc07g056570) aminosav szekvencia leginkább az AtNCED3 (At3g14440) szekvenciához hasonlít (23. ábra). A karotinoid hasító dioxigenázok (CCD-k) nagy hasonlóságot mutatnak az NCED szekvenciákkal, azonban önálló csoportot alkotnak a lúdfü 
CCD-kel. Az S1CCD1A és S1CCD1B leginkább a lúdfü AtCCD1 aminosav szekvenciájával mutat hasonlóságot.

További vizsgálatok céljából az SINCED1, S1CCD1A és S1CCD1B szekvenciákat választottuk ki az irodalomban található adatok alapján és a paradicsom és lúdfü aminosav szekvenciák filogenetikai hasonlóságai alapján. Az SINCED és SlCCD1 gének mellet vizsgáltuk egy SIZEP és három SIAO (SlAO1, SlAO2 és SlAO3) gén expresszióját is.

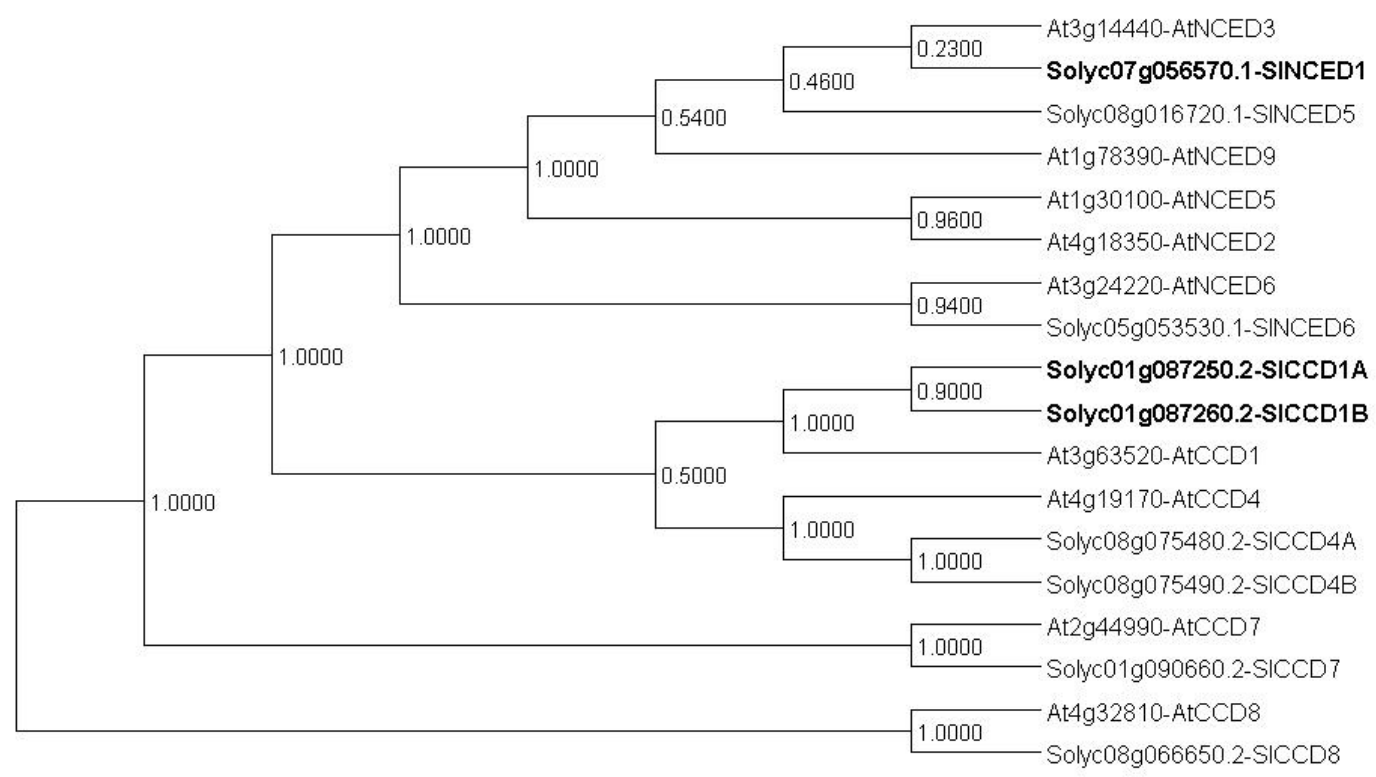

23. ábra: Rokonsági fa (filogram) a paradicsom és lúdfü ismert NCED és CCD szekvenciáiból. A rokonsági fán az SGN és TAIR adatbázisban található szekvenciák azonosítási számai láthatóak. A szekvenciákat az SGN és TAIR adatbázisokban fellelhető név alapján neveztük el és az ábrán félkövér betűvel jelöltük az általunk vizsgált gének nevét.

Az ABS bioszintézisében szerepet játszó gének a 4 hetes SA kezelés hatására koncentrációfüggő módon indukálódtak, és gyökérben sokkal nagyobb mértékű változásokat detektáltunk, mint levélben. Az ABS bioszintézisének első lépéséért felelős enzimet kódoló SIZEP gén expresszióját, a $10^{-4} \mathrm{M}$ SA kezelés levélben csak kis mértékben, gyökérben viszont szignifikánsan indukálta. Sóstressz hatására a SA előkezelt és -kezeletlen mintákban is represszálódott az SIZEP gén (24. ábra). 

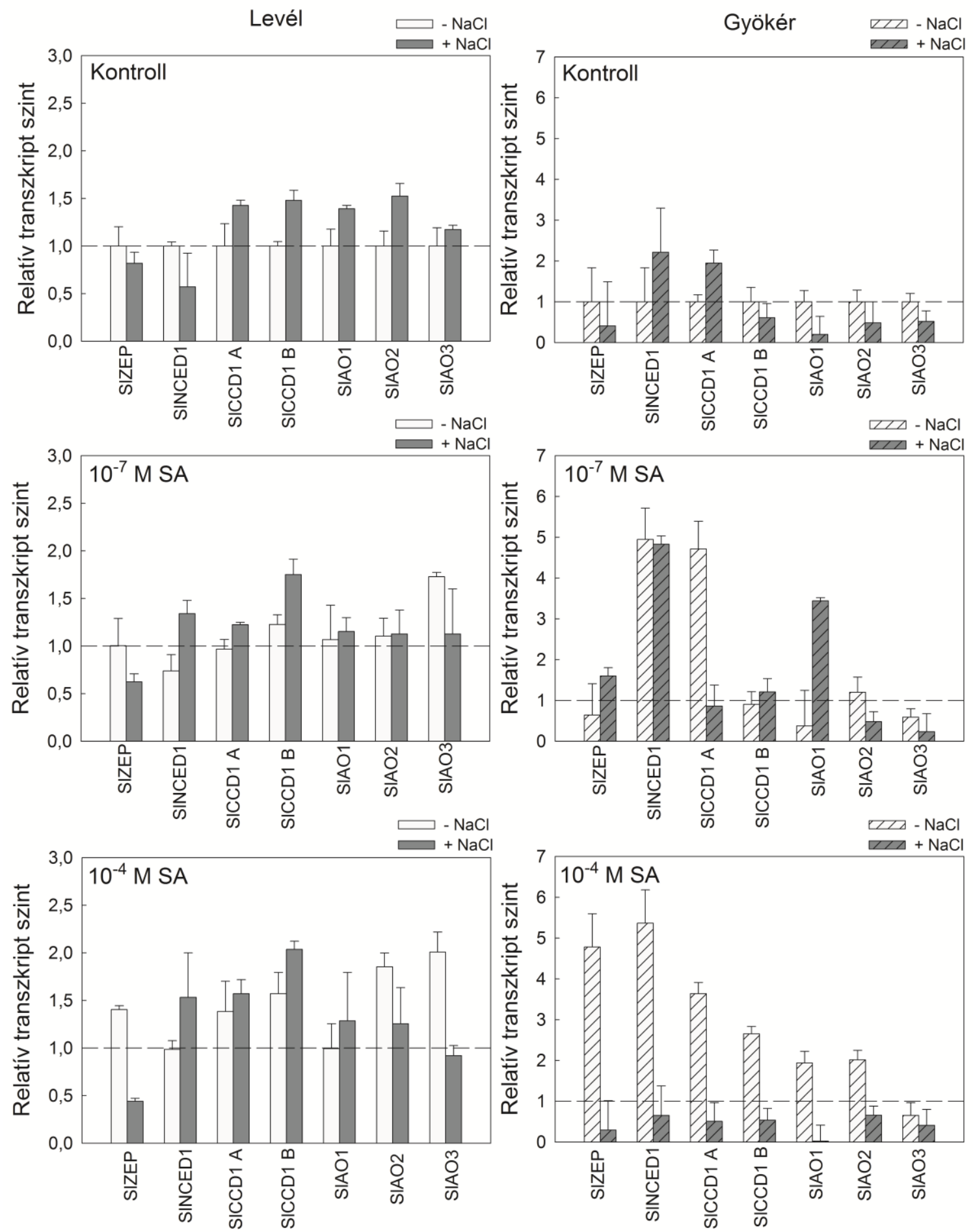

24. ábra: Három hét $10^{-7} \mathrm{M}$ és $10^{-4} \mathrm{M}$ SA elökezelés hatása paradicsom növények levelének és gyökerének ABS bioszintézis gének transzkript szint változására 1 hetes, $100 \mathrm{mM} \mathrm{NaCl}$ kezelést követően (átlag $\pm \mathrm{SD}, \mathrm{n}=3$ ). (- $\mathrm{NaCl}$ : nem sókezelt minták; $+\mathrm{NaCl}$ : $100 \mathrm{mM} \mathrm{NaCl}-$ dal kiváltott sóstressznek kitett növények). A transzkript szint relatív egysége a hajtás vagy gyökér kontroll mintáiban mért relatív transzkript szint (=1), amelyet szaggatott vonal jelöl az ábrákon. 
Az ABS bioszintézis kulcs enzimét kódoló SINCEDl gén, expressziója gyökérben indukálódott mindkét SA előkezelés hatására, levélben kontroll szintű kifejeződést mutatott. Egy hét $100 \mathrm{mM} \mathrm{NaCl}$ kezelést követően az SINCEDl gén expressziója levélben enyhe csökkenést, gyökérben pedig mintegy 2-szeres növekedést mutatott. A vizsgált SA koncentrációk különböző módon befolyásolták az SINCED1 kifejeződését a sóstressz során. $10^{-7} \mathrm{M}$ SA előkezelés hatására az egy hét sóstressz megemelte, $10^{-4} \mathrm{M} \mathrm{SA}$ viszont kontroll szintre csökkentette az SINCED1 gén expresszióját.

Levélben a SA csak kismértékben hatott a SlCCD-k expressziójára, de sokkal kifejezettebb változások voltak gyökérben. Az SlCCDIA transzkripciós szintje gyökérben mindkét SA előkezelés hatására megemelkedett. $100 \mathrm{mM} \mathrm{NaCl}$ kismértékben indukálta expressziójukat a levélben, azonban gyökérben csökkent az átírásuk sóstressz során a SA előkezelések hatására (24. ábra).

Kísérleteink során három SlAO gén expresszióját tanulmányoztuk. Az SA előkezelés koncentrációfüggő módon változtatta az SlAO gének expresszióját. Levélben a $10^{-4} \mathrm{M} \mathrm{SA}$ előkezelés fokozta az SlAO2 és SlAO3 gének expresszióját, a $10^{-7} \mathrm{M}$ SA előkezelés viszont nem idézett elő szignifikáns változást. Gyökérben a $10^{-4} \mathrm{M} \mathrm{SA}$ indukálta az SlAO1 és SlAO2 expresszióját, viszont az SlAO3 nem mutatott indukciót. A sókezelés csökkentette a vizsgált SlAO gének expresszióját kontroll és SA előkezelt növényekben egyaránt, kivéve a SlAO1 gént, amelynek mRNS szintje megemelkedett a $10^{-7} \mathrm{M}$ SA elökezelt gyökerekben egy hét sókezelést követően (24. ábra). 


\section{Eredmények értékelése}

\subsection{A hosszútávú SA előkezelés hatása a lúdfü és paradicsom növények sóstressz akklimatizációjára}

A SA-at, mint növényi hormont elsősorban a biotikus stressz során jelentkező védekezési mechanizmusok indukciójával kapcsolták össze, azonban egyre több bizonyíték halmozódott fel az elmúlt években arra vonatkozóan, hogy a SA az abiotikus stresszválaszt is képes szabályozni. A külsőleg alkalmazott SA, megfelelő koncentrációban számos módon hathat a növények fiziológiai folyamataira, köztük az antioxidánsok aktiválásával, ami hatékonyabb stressz toleranciához vezethet (Horváth és mtsai. 2007, Ashraf és mtsai. 2010). Annak érdekében, hogy a SA sóstressz elleni védekezésben betöltött szerepét jobban megérthessük, kísérleteinkben a hosszútávú ,priming”-ra fókuszáltunk, amelyet hosszan tartó sóstressz (egy hét $100 \mathrm{mM} \mathrm{NaCl}$ ) követett a növényekben.

Korábbi eredményeink azt mutatták, hogy paradicsom növényekben a hosszútávú SA elökezelés szignifikánsan javította az egy hétig tartó, magas sókoncentrációval $(100 \mathrm{mM}$ $\mathrm{NaCl}$ ) szembeni toleranciát. A $10^{-4} \mathrm{M}$ SA elősegítette az akklimatizáció folyamatát és enyhítette a másodlagosan alkalmazott sóstressz károsító hatását. A sóstressznek kitett paradicsom növények SA elökezelése megemelte az ABS szintjét, javította a növények vízmegtartó kapacitását és az ozmotikus adaptációját (Szepesi és mtsai. 2009). Jelen kísérleteinkben bizonyítottuk, hogy $10^{-7} \mathrm{M}$ SA alkalmazása esetén csak az SINCEDl gén transzkript szintje emelkedett meg, $10^{-4} \mathrm{M}$ SA hatására viszont az ABS bioszintézis minden fontosabb lépése indukálódott (SIZEP, SINCED1 és SIAO-k). Filogenetikai vizsgálatainkból kiderült, hogy az SINCED1 hasonlóságot mutat az AtNCED3 és AtNCED9 szekvenciákkal, amelyek irodalmi adatok szerint szoros kapcsolatot mutattak a megemelkedett ABS akkumulációval Arabidopsis magokban (Lefebvre és mtsai. 2006, Kanno és mtsai. 2010). Az LeNCED1 (jelenlegi nevén SINCED1) gén dohány növényekben történő túltermeltetése magasabb ABS szintet eredményezett, amely jobb védelmet biztosít szárazság stressz esetén (Tung és mtsai. 2008). Kísérleteinkben a SA előkezelés paradicsom gyökérben indukálta az SINCED1 gént és ABS akkumulációt váltott ki, de csak a magasabb SA koncentráció, a $10^{-4}$ M előkezelés hatására emelkedett meg az ABS a növények levelében is (Szepesi és mtsai. 2009). Habár az NCED-t tartják az ABS bioszintézis legfontosabb szabályozó enzimének, a SA kezelés a ZEP és AO izoenzimeket is befolyásolta. Endo és mtsai. (2008) az ABS 
bioszintézis szöveti lokalizációját derítették fel AtNCED3 és AtAO3 antitestek alkalmazásával, és azt találták, hogy a korai válaszban a gének indukciója a vaszkuláris parenchima sejtekre korlátozódott. Más közleményekhez hasonlóan (Gallé és mtsai. 2013), kísérleti rendszerünkben az ABS bioszintézis gének a SA előkezelés hatására jobban indukálódtak gyökérben, mint hajtásban, viszont az ABS akkumulációja magasabb volt a levelekben. Ennek hátterében a hatékonyabb transzport állhat.

A karotinoid hasító dioxigenáz funkcióval rendelkező aminosav szekvenciákból létrehozott törzsfán az SINCED-kel nagy hasonóságot mutató S1CCD-k egy különálló csoportot alkotnak. A CCD-k és termékeik a fejlődésben, a növény és gomba kölcsönhatásban vesznek részt és a növényi illat- és ízanyagok összetevői között is szerepelnek (Camara és Bouvier 2004). A CCD-k ezen csoportja az olyan apokarotinoidok szintézisében játszik szerepet, mint a $\beta$ ciklocitrál, $\beta$-jonon, geraniál, teaspiron és damaszcenon (Auldridge és mtsai. 2006). Az S1CCD1A és SICCD1B, amelyek a $\beta$-jonon, geranilaceton és pszeudojonon szintézisét katalizálják különböző karotinoid szubsztrátokból, hasonlóak az AtCCD1-hez (Simkin és mtsai. 2004). Ramel és mtsai. (2012) véleménye szerint az apokarotinoidok jelmolekulákként funkcionálhatnak a növényekben, így az SlCCD1 gének megemelkedett transzkript szintje olyan változásokat indukálhat a paradicsom növények előkezelése során, amelyek új, eddig még ismeretlen apokarotinoid-szabályozás alatt álló útvonalakat indukálnak.

Yasuda és mtsai. (2008) a BIT (1,2-benzisothiazol-3(2H)-one1,1-dioxide) kémiai elicitort alkalmazták, hogy SA jelátvitel indukálásával aktiválják a SAR-t. A BIT-indukált SA akkumuláció és -SA jelátvitel exogén ABS hozzáadásával lúdfü növényekben visszaszorítható volt. Emellett a BIT kezelés lecsökkentette a NaCl-indukált ABS bioszintézist, Az ABAl és NCED3 expresszióját, de az ABA2 és AO3 génekét nem befolyásolta (Yasuda és mtsai. 2008). A $10^{-7} \mathrm{M}$ SA koncentrációval ellentétben a $10^{-4} \mathrm{M}$ SA - hasonlóan a BIT kezeléshez megemelte a paradicsom növényekben az SIZEP, SINCED1 és SIAO1 gének transzkript mennyiségét. Habár magas sókoncentráció lecsökkentette a SA előkezelt mintákban a gének expresszióját gyökérben vagy gátolta az S1AO aktivitást, az ABS szintje a kontroll felett maradt, így azt feltételezhetjük, hogy az ABS lebontás mértéke is csökkent a ,priming” során. (Szepesi és mtsai. 2009).

Lovelli és mtsai. (2012) paradicsom szövetekben közvetlen kapcsolatot találtak az ABS és a $\mathrm{Na}$ tartalom között. Korábbi kísérleteink során a SA előkezelés csökkentette a $\mathrm{Na}$ koncentrációt a gyökérben a sókezelt kontrollhoz képest, azonban a Na hajtásba történő 
transzportja fokozódott. Az ABS szintje a levelekben ezzel egy időben kismértékben meghaladta a csak sókezelt növényekben mérhetőt (Szepesi és mtsai 2009). A növekedés és a fejlődés fenntartása sós környezetben az ozmotikus szabályozáshoz köthető, ami a kompatibilis ozmotikumok szintézisén vagy - egyes sótoleráns fajokban és halofitákban - a Na vakuólumban történő akkumulációján keresztül valósulhat meg (Munns 2002, Szepesi és mtsai. 2009). A SA elökezelést követően a paradicsom levelek halofita jelleget mutattak és több Na-ot tartalmaztak, mint a csak sókezelt kontroll levelek (Szepesi és mtsai 2009). A sótoleráns paradicsom fajtákban a rezisztencia alacsonyabb $\mathrm{Na}$ - és magasabb $\mathrm{K}$ akkumulációval, a levelekben nagyobb szacharóz, karotinoid és redukált tiol felhalmozódással és alacsonyabb oxidatív károsodással jellemezhető (Juan és mtsai. 2005). Ezek a növények sós környezetben képesek a magasabb biomassza produkcióra. A megemelkedett gyökérnövekedéssel és magasabb gyökér biomasszával jellemezhető paradicsom pedig jobb toleranciát mutatott magas koncentrációjú sóstressz alatt (Lovelli és mtsai. 2012). A $10^{-7} \mathrm{M}$ SA-val előkezelt paradicsom növényekkel ellentétben, a ,priming” hatással rendelkező $10^{-4} \mathrm{M}$ SA kezelés elősegítette a gyökérnövekedést sóstressz során. A paradicsom növényekben tapasztaltakhoz hasonlóan, a $10^{-5} \mathrm{M}$ SA előkezelt lúdfü növények magasabb $\mathrm{K} / \mathrm{Na}$ arányt tartottak fenn sóstressz során a gyökerükben és nagyobb gyökér- és hajtás friss tömeggel, hajtás rozetta átmérővel rendelkeztek a sókezelt kontrollhoz képest, a levélben mért megemelkedett Na tartalom mellett.

A $\mathrm{NaCl}$ stressz hatására a ROS szintje megnő, ami károsító hatása mellett a jelátvitelben is fontos szerepet tölthet be, ezért az antioxidáns mechanizmusok a ROS szintjének szabályozásán keresztül kulcsszerepet játszanak a növények sótoleranciájában (Munns és Tester 2008). Eredményeinket összevetve megállapíthatjuk, hogy a $100 \mathrm{mM} \mathrm{NaCl}$ kezelés megemelte a $\mathrm{H}_{2} \mathrm{O}_{2}$ tartalmat a paradicsom és a lúdfü levelében is, a gyökerében viszont ellentétes változásokat idézett elő, paradicsomban csökkentette, lúdfüben növelte a $\mathrm{H}_{2} \mathrm{O}_{2}$ tartalmat. Ezzel párhuzamosan az MDA akkumulációját figyeltük meg lúdfü növények levelében és gyökerében. A SOD, KAT és POD enzimek aktivitása nőtt a sóstressznek kitett lúdfü növények gyökerében, levelükben viszont vagy lecsökkent, vagy kontroll szinten maradt az aktivitásuk. Egy hét $100 \mathrm{mM} \mathrm{NaCl}$ kezelés a 8 hetes paradicsom és lúdfü növényekben megemelte a GST aktivitását, a GPOX aktivitás viszont paradicsom növényekben nőtt, lúdfüben pedig szignifikánsan lecsökkent sóstressz hatására mindkét 
vizsgált szervben. Az antioxidáns enzimek aktivitásának növekedése azonban nem akadályozta meg a ROS és lipidperoxidok akkumulációját egyik vizsgált fajban sem.

A külsőleg alkalmazott SA-ról korábban már kimutatták, hogy koncentrációtól és növényfajtól függően fejti ki hatását (Rivas-San Vicente és Plasencia 2011). Paradicsom növények hosszútávú SA kezelése megakadályozta a magas sókoncentráció hatására bekövetkező fotoszintetikus paraméterek csökkenését (Poór és mtsai. 2011), csökkentette a ROS, a nitrogén monoxid és a MDA tartalmat (Szepesi és mtsai. 2008, Gémes és mtsai. 2011) és megemelte egyes antioxidánsok aktivitását (Szepesi és mtsai. 2005, Tari és mtsai 2015). A ROS akkumulációt az antioxidáns rendszer szabályozza, amely gyakran indukálódik stressz hatására (Gill és Tuteja 2010). A SA előkezelés a magasabb (paradicsomban $10^{-4} \mathrm{M}$, lúdfüben $\left.10^{-5} \mathrm{M}\right)$ koncentrációban alkalmazva mindkét vizsgált fajban csökkentette sóstressz során a $\mathrm{H}_{2} \mathrm{O}_{2}$ szintjében bekövetkező változásokat. A több héten át tartó SA kezelés önmagában általában nem befolyásolta a SOD és POD aktivitásokat, kivéve a $10^{-6}$ és $10^{-5} \mathrm{M}$ SA előkezeléseket, amelyek megemelték a SOD és POD aktivitását. A sóstressz lúdfüben megemelte a POD aktivitását a $10^{-7}-10^{-5} \mathrm{M}$ SA elökezelt növények gyökerében. Ehhez hasonló eredményt kaptak Noreen és mtsai. (2009) napraforgó növényekben, ahol a SA enyhítette a $120 \mathrm{mM} \mathrm{NaCl}$ kezelés növekedésgátló hatását, föként a POD aktivitás növelésével. A peroxidázok különböző biotikus és abiotikus stresszválaszokban érintettek, többek között a patogének elleni védekezésben, nehézfém-, hideg-, szárazság- és sóstressz válaszban (De Gara 2004, Cosio és mtsai. 2009, Csiszár és mtsai. 2012). Ezek az enzimek a $\mathrm{H}_{2} \mathrm{O}_{2}$ redukcióját katalizálják különböző donorokról származó elektronok felhasználásával (Passardi és mtsai. 2004). Lúdfüben tehát a hosszútávú SA-indukált sóstressz akklimatizációt legalább részben magyarázhatjuk a POD aktivitás emelkedésével. A DHAR aktivitása a sókezelést követően a $10^{-4} \mathrm{M}$ SA-val elökezelt növények gyökerében kontroll szinten maradt, viszont a $10^{-7} \mathrm{M}$ SA kezelés lecsökkentette, ami azt sugallja, hogy a $10^{-4} \mathrm{M}$ SA előkezelés hatékonyabb a „priming” kialakításában a $10^{-7} \mathrm{M}$ SA kezeléshez képest paradicsom növényekben (Gémes és mtsai. 2011). Emellett, a magasabb GST és GPOX aktivitás a SA elökezelt növényekben arra utal, hogy a GST-k aktiválása a „priming” hatás fontos részét képezi és hozzájárulhat a növények megemelkedett rezisztenciájához a hosszútávú válaszban. A GST-k a sóstressz során fellépő oxidatív károsodás elleni védelemben játszanak szerepet azáltal, hogy megakadályozzák a szerves hidroperoxidok citotoxikus aldehidekké történő alakulását (Zhang és mtsai. 2012). 
A GST és GPOX aktivitásának hátterében álló folyamatok jobb megismerése érdekében megvizsgáltuk a SA elökezelt és sóstressznek kitett paradicsom és lúdfü növényekben néhány kiválasztott GST gén expresszióját QRT-PCR módszerrel. A GST enzimcsalád paradicsomban 81 tagból áll, amelyek közül 78 tartozik a 6 szolubilis csoport valamelyikébe. Olyan SlGST géneket választottunk ki további vizsgálat céljából, amelyek nagy hasonlóságot mutatnak a CDNB és CHP szubsztrátokkal szemben magas affinitással rendelkező lúdfü GST-kel (Dixon és mtsai. 2009). A vizsgált SlGST gének expressziója eltérő volt a levélben és a gyökérben, emellett a SA előkezelés koncentráció-függő módon hatott a GST-k expressziójára. A $10^{-7} \mathrm{M} \mathrm{SA}$ kezelés hatására levélben egyedül az SlGSTF4 gén indukálódott, a magasabb, $10^{-4} \mathrm{M}$ SA koncentráció viszont megemelte az SlGSTF4 és SlGSTU26 mRNS szintjét. Gyökérben mindkét SA koncentráció hatására nőtt az SlGSTF4, SlGSTU23, SlGSTU26, SlGSTZ2, SlGSTT2, SIDHAR5 és SlGSTL3 gének transzkript szintje, $10^{-4} \mathrm{M} \mathrm{SA}$ elökezelés azonban nagyobb mértékben növelte a gének átírását. Mivel paradicsom levelében és gyökerében egyaránt a phi és tau csoportba tartozó GST-k is megemelkedett SA-választ mutattak, lúdfúben az ebbe a csoportba tartozó géneket választottunk ki további vizsgálatra. Érdekes módon az AtGSTF8 gén, amiben az in silico promóter régió vizsgálatokban több SAkapcsolódó elemet is találtunk (TCA-elem és TGACG-motívum), hosszútávú SA kezelés hatására represszálódott, nem úgy mint a paradicsomban található ortológja, az SIGSTF4 (4. táblázat). Az SlGSTF4 promóterében szintén jelen voltak a SA-ható elemek egy-egy kópiában, a TC-gazdag ismétlödések és $M B S$ elem viszont több kópiában. Lúdfü növényekben az AtGSTU24 és az AtGSTU19 gének, amelyeknek a promóter régiójában szintén megtalálhatóak voltak az abiotikus stresszválasz elemek, a TC-gazdag ismétlödések és MBS elem és mellette a SA-ható elem TGACG-motívum is, indukciót mutattak. A különböző gének 5' szabályozó régiójában található főbb abiotikus stressz- illetve hormonválaszért felelős ciszható elemek számát, elhelyezkedését tekintve nem találtunk egyértelmü összefüggést azok megléte, száma illetve a megfigyelt expressziós változások között (4. táblázat). Eredményeink azt mutatják, hogy az egyes GST izoenzimek mind fajon belül, mind az ortológokat tekintve igen összetett, egyedi szabályozás alatt állnak. Mivel azonban a nukleotid motívumok nemcsak a promóter régióban, hanem az egész genomban szétszórtan helyezkedhetnek el, feltételezett szabályozó funkciójuk igazolására további kísérletek szükségesek. 
4. táblázat: A kiválasztott GST gének 1,5 $\mathrm{kbp} 5$ ' promóter régiójában található fontosabb hormon- és stressz-indukálható elemek. Plusz (+) jel jelöli az adott cisz-ható elem meglétét és számát a szabályozó régióban.

\begin{tabular}{|c|c|c|c|c|c|c|c|}
\hline \multirow[b]{2}{*}{$\begin{array}{l}\text { A gén } \\
\text { neve }\end{array}$} & \multicolumn{7}{|c|}{ Cisz-ható elem megnevezése } \\
\hline & $\begin{array}{l}\text { TCA- } \\
\text { elem }\end{array}$ & $\begin{array}{l}\text { TGACG- } \\
\text { motívum }\end{array}$ & ABRE & ERE & $\begin{array}{l}\text { TC-gazd. } \\
\text { ismétlödések }\end{array}$ & MBS & MBSII \\
\hline AtGSTF8 & +++ & +++++ & + & & + & + & \\
\hline AtGSTF9 & +++ & ++ & ++ & & + & & \\
\hline SlGSTF4 & + & + & ++ & & +++ & +++ & \\
\hline SlGSTF5 & + & & ++ & & ++ & + & + \\
\hline AtGSTU19 & & ++++ & & & +++ & ++++ & \\
\hline AtGSTU24 & & + & & & +++ & +++ & \\
\hline AtGSTU25 & + & +++ & & & + & & \\
\hline SlGSTU6 & ++ & & & & ++++ & & \\
\hline SlGSTU23 & & ++ & ++ & +++ & ++ & + & \\
\hline SlGSTU24 & & ++ & ++ & + & +++ & + & \\
\hline SlGSTU26 & + & + & & & + & & + \\
\hline SlGSTZ2 & ++ & & & ++ & ++ & & \\
\hline SIGSTT2 & ++ & & + & + & & ++ & \\
\hline SIDHAR2 & & & & & + & & \\
\hline SIDHAR5 & & & & & + & + & \\
\hline SIGSTL3 & & + & + & & ++ & + & \\
\hline
\end{tabular}

Az SlGSTU23 és SlGSTU26 expressziója levélben megemelkedett a sókezelés hatására. A „priming”-ot követően sóstressz hatására a levelekben az SIGSTU23 expressziója csökkent, de az SIGSTU26 aktivációja pótolhatta ezt a csökkenést. Lúdfüben sóstressz hatására szintén indukálódott a tau csoportba tartozó AtGSTU19 és AtGSTU24 gének expressziója. Ezt az indukciót a $10^{-7} \mathrm{M}$ SA előkezelés tovább fokozta, a $10^{-5} \mathrm{M}$ SA előkezelés azonban lecsökkentette azt. A tau csoportú GST-k GSH-konjugáló aktivitással rendelkeznek különféle xenobiotikumokkal szemben rizsben (Yang és mtsai. 2009) és nyárfában (Lan és mtsai. 2009), így valószínűleg részt vesznek a mérgező anyagcseretermékek GSH-konjugációjában a paradicsom és lúdfü levelében is sóstressz alatt. Az eredményeink arra utalnak, hogy a GST aktivitásban mért változások a SA előkezelt lúdfü növényekben legalább részben az AtGSTU19 és AtGSTU24 gének különböző transzkripciós aktiválásával függ össze.

Amíg a lúdfü gyökerében a tau csoportú GST-k indukciója volt megfigyelhető, addig a paradicsom gyökerében az SIGSTT2, SIGSTZ2, SIGSTL3 és SIDHAR5 gének expressziója emelkedett meg a sóstressz során.

Ezek a GST-k expressziós mintázatában bekövetkező változások tünnek leginkább jellemzőnek a SA „priming”-ra paradicsomban. Az alacsony SA-val szemben, a magas SA koncentrációval történő „,priming” fenntartotta a sóstresszelt növényekéhez hasonló SlGSTZ2, 
SlGSTT2, SlGSTL3 és SIDHAR5 génexpressziót, ami alapján arra következtethetünk, hogy ezek a GST-k fontos szerepet játszanak a paradicsom növények sóstressz akklimatizációjában. A zéta, théta és DHAR csoportba tartozó $S l G S T$-k expressziójának aktiválódása egy hét sókezelés után csak a gyökérben volt megfigyelhető, ami arra utal, hogy az általuk katalizált kémiai reakciók a gyökérben fontosak a sóstressz során. A théta csoportba tartózó enzimek magas GPOX aktivitással rendelkeznek, ezért az SIGSTT2 kifejeződésében tapasztalt növekedés, ami az AtGSTT1 homológja, hozzájárulhat a GSH függő lipid hidroperoxidok eliminálásához a peroxiszómákban (Dixon és Edwards 2010).

Összegezve, eredményeink arra utalnak, hogy a GST-k fontos résztvevői a változó környezeti jelekhez történő alkalmazkodásnak. A módosult GST expressziós szintek és a GST izoenzimek megnövekedett vagy gátolt aktivitása, amelyek különféle feladatot látnak el, aktív részesei a hosszabb távú stressz válasznak, így a SA hatására kialakuló „priming”-ban is szerepet játszanak és javíthatják a sótoleranciát paradicsom növényekben.

\subsection{GST mutáció hatása Arabidopsis thaliana rövidtávú sóstressz válaszára}

A GST-k szerepét a detoxifikáló mechanizmusok során már több közleményben leírták (Bray 2002, DeRidder és mtsai. 2002, Ndimba és mtsai. 2005, Sarry és mtsai. 2006), de az egyes GST-k pontos szerepéröl a fejlödésben és stressz elleni védekezésben kevesebb információ áll rendelkezésünkre. Az AtGSTF9 más GST-k mellett, mint az AtGSTF2, AtGSTF6/7, AtGSTF10, AtDHAR1, AtDHAR3, AtGSTU5 és AtGSTU19, nagy mennyiségben jelen van a kontroll növények hajtásában és a sejtkultúrában is (Sappl és mtsai. 2004). Hosszútávú kísérleteinkben azt tapasztaltuk, hogy az AtGSTU19 és az AtGSTF9 gének expressziója eltérő módon változott az alkalmazott só- és SA kezelések hatására. Ezért rövidtávú só- és SA kezelés során vizsgáltuk az AtGSTU19 és az AtGSTF9 gének mutációjának hatását a csíranövényekben mérhető GST aktivitásra és az életképességre. Ezen felül 2 hét $150 \mathrm{mM}$ $\mathrm{NaCl}$ vagy $10^{-5} \mathrm{M}$ SA kezelés hatására mértük a csíranövények gyökérnövekedését.

Az AtGSTF9 amellett, hogy részt vesz a virág kialakításában (Chua és mtsai. 2010) és a gyökér mozgásának szabályozásában (Schafer és Buettner 2001), részt vesz az alacsony koncentrációjú Cd kezelés során a ROS detoxifikálásában és ezáltal az oxidatív stresszválasz kialakításában (Semane és mtsai. 2010). Vizsgálataink során megállapítottuk, hogy a két hetes Atgstf9 mutáns növények gyökere szignifikánsan rövidebb kontroll körülmények között, 
azonban a $150 \mathrm{mM} \mathrm{NaCl}$ vagy $10^{-5} \mathrm{M}$ SA kezelés csak kisebb eltérést okozott a vad típushoz képest. Az eredmények arra utalnak, hogy a csíranövények gyökérnövekedésében kontroll körülmények között és NaCl- vagy SA kezelés alatt is szerepet játszik az AtGSTF9. A só- és SA kezelés hatására megemelkedett GST aktivitás az Atgstf9 mutánsban a GST-k magas fokú redundanciájával magyarázható, ami más GST izoenzimek aktiválódásával a GSH-konjugáló aktivitás növekedéséhez vezethetett a mutánsokban (pl. a hosszútávú kísérletekben az AtGSTU19 és AtGSTU24 gének indukcióját figyelhettük meg SA előkezelés és sóstressz hatására is). A növények életképessége SA kezelés során a vad típusúéhoz hasonló volt viszont sóstressz során nagyobb csökkenést figyeltünk meg a mutánsokban mint a vad típusban, ami arra utal, hogy az AtGSTF9 a sóstressz során játszik fontosabb szerepet.

Az AtGSTF9 mellett az AtGSTU19 is azok a GST-k közé tartozik, amelyek indukcióját számos fejlődési és stresszfolyamat során leírták lúdfüben. Az AtGSTU19 gén fontos szerepet játszik a patogének elleni védekezésben (Cartieaux és mtsai. 2008), szeneszcencia folyamatában (Gepstein és mtsai. 2003), vízhiányos állapot során (Bray 2002), de szerepet játszhat a hajtás fejlődésében (Che és mtsai. 2002), sejtciklus szabályozásában (Menges és mtsai. 2002) és a járulékos gyökérfejlődésben (Sorin és mtsai. 2006). Az Atgstu19 mutánsokban kontroll körülmények között alacsonyabb GST aktivitást mértünk, ami só- és SA kezelés hatására sem emelkedett meg, ellentétben a vad típusú lúdfü növényekkel. Ez az eredmény arra utal, hogy az AtGSTU19 gén jelentős részét adja a CDNB szubsztráttal szemben mérhető GST aktivitásnak. Az AtGSTU19 RNS és protein szintjének indukcióját kimutatták herbicidek és herbicid antidótumok hatására (benoxacor, fenclorim, fluxofenim) (DeRidder és mtsai. 2002). AtGSTU19::GFP transzgénikus lúdfü vonalban kimutatták, hogy benoxacor alkalmazása során a csíranövény minden szervében indukálódik az AtGSTU19, de leginkább gyökérben nő meg az expressziója (DeRidder és Goldsbrough 2006). Az abiotikus stressz során gyakran másodlagos stresszhatásként jelentkező oxidatív stressz következtében megemelkedik a sejtekben a lipidperoxidáció. Az AtGSTU19 indukciója a herbicidek hatására a detoxifikáló folyamatokban játszott szerepére utal. Ezt az eredményt erősíti az AtGSTU19 protein indukciója só-, ozmotikus-, hő- és Cd stressz során (Ndimba és mtsai. 2005, Sarry és mtsai. 2006, Lee és mtsai. 2009). Detoxifikációban betöltött szerepe magyarázhatja az Atgstu19 mutánsokban megfigyelt nagyobb mértékü életképesség csökkenést a vad típushoz viszonyítva rövid távú só- és SA kezelések hatására. Emellett az Atgstu19 mutánsok két hetes só- és SA kezelés hatására szignifikánsan alacsonyabb gyökérhosszal rendelkeztek a vad 
típushoz képest, ami a hidropónikus kísérleteink eredményeihez hasonlóan az AtGSTU19 hosszabb távú stresszválaszban betöltött szerepére utal. 


\section{7. Összefoglalás}

Kísérleteink során a lúdfü és paradicsom növények SA előkezelést követő sóstressz akklimatizációban résztvevő egyes elemeit vizsgáltuk és a következő főbb megfigyeléseket tettük:

Arabidopsis thaliana L. növényen végzett hosszútávú kísérletekben:

1. A széles koncentráció tartományban alkalmazott $\mathrm{SA}\left(10^{-9}-10^{-5} \mathrm{M}\right)$ a szakirodalomnak megfelelően koncentrációfüggő módon hatottak a lúdfü növények hajtás és gyökérnövekedésére. Minden SA koncentráció serkentette a hajtás növekedését, sóstressz során pedig a magasabb koncentrációjú, $10^{-6}$ és $10^{-5} \mathrm{M}$ SA-val történő előkezelések bizonyultak leghatékonyabbnak a növekedésgátlás kivédésében. A SA kezelések befolyásolták a $\mathrm{Na}$ és $\mathrm{K}$ elemtartalmakat levélben és gyökérben, és elősegítették a később alkalmazott sóstressz esetén a $\mathrm{K}$ felvételét, gyökérben csökkentették a Na akkumulációt, levélben viszont a Na akkumulálódását serkentették. $10^{-6}$ és $10^{-5} \mathrm{M}$ SA kezelés hatására nőtt a $\mathrm{K} / \mathrm{Na}$ arány a gyökerekben, ami hozzájárulhatott a növekedés fenntartásához. Emellett a SA előkezelés csökkentette a $\mathrm{H}_{2} \mathrm{O}_{2}$ és MDA akkumulációt lúdfüben. „Priming” hatása a $10^{-5} \mathrm{M}$ SA koncentrációnak volt, amely segített megőrizni a növények növekedését sóstressz során, ami kulcsfontosságú szerepet tölt be a sikeresebb akklimatizációban.

2. Az antioxidáns enzimek müködésével kapcsolatban megállapítható, hogy a KAT aktivitás gyökérben és levélben egyaránt csökkent, a SOD aktivitása a kontrollhoz hasonló szinten tartották, és a POD aktivitását gyökérben a $10^{-6}$ és $10^{-5} \mathrm{M} \mathrm{SA}$ kezelések megemelték. A különböző SA koncentrációk eltérő módon hatottak a sóstresszre adott antioxidáns válaszra. A $10^{-6}$ és $10^{-5} \mathrm{M}$ SA előkezelés sókezelés hatására még inkább megemelte a POD aktivitását gyökérben, levélben pedig nőtt a SOD aktivitása. Eredményeink arra utalnak, hogy a magasabb POD és/vagy SOD aktivitás a SA elökezelt növényekben hozzájárult a megemelkedett sóstressz akklimatizációhoz, főként a $10^{-6}$ és $10^{-5} \mathrm{M} \mathrm{SA}$ elökezelt lúdfü növényekben.

3. A SA előkezelések koncentrációfüggő módon megemelték a GST és GPOX aktivitást lúdfüben, és $10^{-5} \mathrm{M}$ SA alkalmazása elősegítette sóstressz során a GST és GPOX 
aktivitások további emelkedését, ellentétben az elökezelés nélkül alkalmazott sókezelés hatásával, ahol a GPOX aktivitása csökkent. A további vizsgálatokra kiválasztott AtGSTU19 és AtGSTU24 gének transzkript szintjének emelkedése legalább részben eredményezhette a GST és GPOX aktivitásokban tapasztalt indukciót.

Arabidopsis thaliana L. GST mutáns növényeken végzett rövid távú kísérletekben:

4. Az Arabidopsis inszerciós mutáns csíranövényeken alkalmazott sóstressz és SA kezelés során a GST aktivitásban és a gyökérnövekedésben megfigyelhető különbségek arra utalnak, hogy mindkét AtGST szerepet játszik a magas só- és SA koncentrációk által indukált folyamatokban. A gyökérnövekedésben mért csökkenés a mutánsokban az AtGSTU19 és AtGSTF9 izoenzimek a sóstressz válaszban betöltött pozitív szerepére utalnak, feltehetően azáltal, hogy szabályozzák a detoxifikáló folyamatokat és ezzel a sejtek homeosztázisának fenntartását segítik elő, és végső soron elősegítik a növények növekedését.

Solanum lycopersicum Mill. L. cvar. Rio Fuego növényeken végzett kísérletekben:

5. A SA ,priming” a paradicsom növényekben is megemelte a GST és GPOX aktivitását a sóstressz után. Az SlGSTF4 és SLGSTU26 expressziója a levélben, az SlGSTT2, SlGSTZ2 és SlGSTL3 kifejeződése a gyökérben emelkedett meg, így elképzelhető, hogy ezen gének termékei hozzájárulhattak a magasabb GST és GPOX aktivitásokhoz és fontosak a megnövekedett stressztolerancia kialakításában.

6. Az ABS szintjében korábban megfigyelt változások részben magyarázhatóak az AO aktivitásában és az ABS bioszintézis gének kifejeződésében tapasztalt különbségekkel. Az előkezelések során a SA indukálta az ABS bioszintézis gének expresszióját, főként a gyökérben, azonban csak a $10^{-4} \mathrm{M} \mathrm{SA}$ koncentráció indukálta a hormon levélben történő akkumulációját. A sóstressz után megfigyelhető ABS bioszintézis gének repressziója és az AO aktivitás gátlása a $10^{-4} \mathrm{M}$ SA előkezelt mintákban nem akadályozta meg az ABS kontroll szint felett tartását (Szepesi és mtsai. 2009). Ezek alapján feltételezzük, hogy a „,priming” hatására az ABS lebontás is gátlódik. Azt a 
következtetést vonhatjuk le, hogy a paradicsom növények SA-val kiváltott „priming”ja összetett folyamat, ami az ABS akkumuláció szabályozásán túl más SA- és ABS jelátvitel függő folyamatokat is magába foglalhat.

7. Bár a két növényfaj növekedésére a ,priming”-ot kiváltó SA elökezelés különbözően hatott (paradicsomban a $10^{-4} \mathrm{M}$ csökkentette, lúdfüben a $10^{-5} \mathrm{M}$ SA koncentráció fokozta), a sóstressz során mindkét fajra a nagyobb gyökér- és hajtáshossz volt jellemző, ami legalább részben a hasonló $\mathrm{Na}$ - és $\mathrm{K}$ elemtartalombeli változásoknak tudható be (a paradicsomban mért K és Na tartalmak Szepesi és mtsai. 2009-es cikkében szerepelnek). Az előkezelések a paradicsomban leírtakhoz (Gémes és mtsai. 2011) hasonlóan csökkentették a $\mathrm{H}_{2} \mathrm{O}_{2}$ és MDA akkumulációt lúdfüben is. Ezek az eredmények arra utalnak, hogy a SA-szabályozása alatt álló akklimatizáció a ROS- és peroxid detoxifikáló enzimek aktivitásának szabályozásán keresztül képes a sóstressz okozta oxidatív károsodás csökkentésére. Ebben a folyamatban az antioxidáns enzimek és a GST-k is fontos szerepet töltenek be paradicsomban (Tari és mtsai. 2015, Szepesi és mtsai. 2008) és lúdfüben egyaránt. Mindkét növényfajban megemelkedett a GST és GPOX enzimek aktivitása és specifikus mintázatot mutatott a GST gének transzkript szintje a „priming”-ot követő sóstressz után. Mindkét fajban azonosítottunk olyan GST géneket, amelyek indukciót mutattak „priming” során, így arra következtethetünk, hogy az enzimaktivitásokban mért változások egy része nagy valószínüséggel a kulcsfontosságú detoxifikáló enzimek génexpressziójának változásával magyarázhatók.

8. A GST gének 5' promóter régiójának cisz-ható elemeit vizsgálva megállapíthatjuk, hogy a génexpresszió komplex szabályozás alatt áll és egyértelmü összefüggést bizonyos elemek előfordulása és az expresszió szabályozása között nem találtunk. Az ortológ szekvenciák promóter régiójának szabályozó elemei nagyon eltérőek lehetnek, így a gének hasonlósága alapján nem lehet általános következtetéseket levonni a különböző növényfajokban megfigyelhető expressziós mintázat alakulására vonatkozóan. 


\section{Summary}

In our experiments we studied certain components of Arabidopsis and tomato plants which took part in salt stress acclimation following salicylic acid (SA) pre-treatment and based on our results we can summarise:

In Arabidopsis thaliana L. plants during the long-term experiments we found:

1. A wide range of SA concentrations $\left(10^{-9}-10^{-5} \mathrm{M}\right)$, similarly to data in the literature, affected the shoot and root growth of Arabidopsis plants on a concentration dependent manner. SA stimulated the growth of shoots, and pre-treatment with higher $\left(10^{-6}\right.$ and $10^{-5} \mathrm{M} \mathrm{SA}$ ) concentrations proved to be effective in preventing the growth inhibition under salt conditions. SA treatments affected the content of $\mathrm{Na}$ and $\mathrm{K}$ elements in leaves and roots, and during salt stress SA pre-treatment facilitated the uptake of $\mathrm{K}$, reduced the $\mathrm{Na}$ accumulation of roots, however it induced the $\mathrm{Na}$ accumulation in leaves. The $10^{-6}$ and $10^{-5} \mathrm{M}$ SA elevated the $\mathrm{K} / \mathrm{Na}$ ratio in roots which could contribute to root growth. Furthermore, the SA pre-treatment reduced the $\mathrm{H}_{2} \mathrm{O}_{2}$ and malondialdehyde (MDA) contents in Arabidopsis. As a result, the $10^{-5} \mathrm{M}$ SA pretreatment was able to induce priming and it improved the growth of plants during salt stress which plays a key role in successful acclimation.

2. We found that the antioxidant catalase (CAT) enzyme activity decreased in roots and leaves, superoxide dismutase (SOD) activity was on control level and guaiacol peroxidase (POD) activity increased in roots of $10^{-6}$ and $10^{-5} \mathrm{M} \mathrm{SA}$ treated plants. SA concentrations affected the response of antioxidant enzymes during salt stress in different ways. Salt treatment enhanced the POD activity in the roots and induced the SOD activity in leaves of $10^{-6}$ and $10^{-5} \mathrm{M} \mathrm{SA}$ pre-treated plants. Our results indicate that the higher POD and/or SOD activities in SA pre-treated plants are part of the increased salt acclimation, in $10^{-6}$ and $10^{-5} \mathrm{M} \mathrm{SA}$ pre-treated Arabidopsis plants.

3. SA induced the glutathione transferase (GST) and glutathione peroxidase (GPOX) activities in Arabidopsis plants, and $10^{-5} \mathrm{M}$ SA promoted the further elevation of GST and GPOX activities in contrast to salt stress which decreased the GPOX activity. The 
induction of GST and GPOX activities could be at least partially the results of the induced expression of AtGSTU19 and AtGSTU24 genes.

Results of short-term experiments of GST mutant Arabidopsis thaliana L. plants:

4. Salt- and SA treatment of Arabidopsis GST-insertional mutant seedlings induced changes in the GST activities and root growth from which we may assume that both of the investigated AtGSTs play a role in response to high salinity- and SA. The reduction of root growth in the mutants refers to the positive role of AtGSTU19 and AtGSTF9 isoenzymes in the salt stress response, probably through the regulation of detoxifying processes and this way favours the maintenance of cell homeostasis and the growth of plants.

The main results of the experiments carried out on Solanum lycopersicum Mill. L. cvar. Rio Fuego plants:

5. Priming with $10^{-4} \mathrm{M}$ SA pre-treatment of tomato plants also induced the GST and GPOX activities after one week of salt stress. The expression of SlGSTF4 and SlGSTU26 genes in leaves and the transcript level of SlGSTT2, SlGSTZ2 and SlGSTL3 genes in roots increased, thus these genes could contribute to the elevated GST and GPOX activities and may be important in the induction of elevated salt tolerance.

6. The changes detected in the levels of abscisic acid (ABA) could be explained by the different result of the different aldehyde oxidase (AO) activities and the changes detected in the expression of $\mathrm{ABA}$ biosynthesis genes. $\mathrm{SA}$ induced the $\mathrm{ABA}$ biosynthesis gene expression during the pre-treatment period, mainly in roots, but only the $10^{-4} \mathrm{M}$ SA concentration induced the accumulation of ABA in leaves. Although ABA biosynthetic genes were down-regulated or the AO activity was inhibited in $10^{-4}$ M SA pre-treated plants under salt stress, the ABA level was kept over the untreated control (Szepesi et al. 2009). These results suggest a reduced ABA degradation in hardened plants. It can be concluded that priming of tomato with SA against salt stress injury is a complex phenomenon, which along with fine tuning of the accumulation of ABA comprises other SA- and ABA signalling-dependent processes. 
7. Although the SA-induced priming affected differently the growth of the two investigated plant species (in tomato the $10^{-4} \mathrm{M}$ SA decreased, in Arabidopsis $10^{-5} \mathrm{M}$ SA concentration enhanced it), during salt stress both species had longer roots and shoots, which could be explained at least partially with the similar changes detected in the $\mathrm{Na}$ and $\mathrm{K}$ contents (the $\mathrm{K}$ and $\mathrm{Na}$ contents of tomato was published earlier in Szepesi et al. 2009). The pre-treatments reduced the accumulation of $\mathrm{H}_{2} \mathrm{O}_{2}$ and MDA in Arabidopsis, similarly to that of detected in tomato (Gémes et al. 2011). These results suggest that SA-mediated acclimation can reduce oxidative damage caused by salt stress through modulating activities of some of the key ROS- and peroxide detoxifying enzymes. In this process the antioxidant enzymes and the GSTs play important role both in tomato (Szepesi et al. 2009, Tari et al. 2015) and in Arabidopsis. After the priming, the GST and GPOX activities increased in both plant species and the GST gene transcript levels had a specific pattern during the subsequent salt stress. GST genes with induced expression during the priming were identified both in tomato and Arabidopsis, thus it could be concluded that at least some of the alterations in enzyme activities are derived from modulation of transcriptional control of key detoxification genes.

8. The investigation of 5 ' promoter region of GST genes revealed that the gene expression is under complex regulation, and clear correlations between the presence of certain elements and the regulation of the expression were not found. The regulatory elements of promoter region of ortholog sequences can easily vary, thus the similarities of the genes are not sufficient to make a general conclusion about the pattern of gene expression in different plant species. 


\section{Felhasznált irodalom}

Abogadallah GM (2010) Antioxidative defense under salt stress. Plant Signaling and Behavior 5: 369-374.

Agarwal S, Sairam RK, Srivastava GC, Meena R C (2005a) Changes in antioxidant enzymes activity and oxidative stress by abscisic acid and salicylic acid in wheat genotypes. Biologia Plantarum 49: 541-550.

Agarwal S, Sairam RK, Srivastava GC, Tyagi A, Meena RC (2005b) Role of ABA, salicylic acid, calcium and hydrogen peroxide on antioxidant enzymes induction in wheat seedlings. Plant Science 169: 559-570.

Ahmad P, Jaleel CA, Salem MA, Nabi G, Sharma S (2010) Roles of enzymatic and nonenzymatic antioxidants in plants during abiotic stress. Critical Reviews in Biotechnology 30: 161-175.

Ahmad AI, Khaliq T, Ahmad A, Basra SMA, Hasnain Z, Ali A (2012) Effect of seed priming with ascorbic acid, salicylic acid and hydrogen peroxide on emergence, vigor and antioxidant activities of maize. African Journal of Biotechnology 11: 1127-1132.

Ahrazem O, Rubio-Moraga A, Trapero A, Gómez-Gómez L (2012) Developmental and stress-regulation of gene expression for a 9-cis-epoxycarotenoid dioxygenase, CstNCED, isolated from Crocus sativus stigmas. Journal of Experimental Botany 63: 681-694.

Ananieva EA, Christov KN, Popova LP (2004) Exogenous treatment with salicylic acid leads to increased antioxidant capacity in leaves of barley plants exposed to paraquat. Journal of Plant Physiology 161: 319-328.

Alonso-Ramírez A, Rodríguez D, Reyes D, Jiménez JA, Nicolás G, López-Climent M, Gómez-Cadenas A, Nicolás C (2009) Evidence for a role of gibberellins in salicylic acid-modulated early plant responses to abiotic stress in Arabidopsis seeds. Plant Physiology 150: 1335-1344.

Asensi-Fabado MA, Munné-Bosch S (2011) The aba3-1 mutant of Arabidopsis thaliana withstands moderate doses of salt stress by modulating leaf growth and salicylic acid levels. Journal of Plant Growth Regulation 30: 456-466.

Ashraf M, Akram NA, Arteca RN and Foolad MR (2010) The physiological, biochemical and molecular roles of brassinosteroids and salicylic acid in plant processes and salt tolerance. Critical Reviews in Plant Sciences 29: 162-190.

Auldridge ME, McCarty DR, Klee HJ (2006) Plant carotenoid cleavage oxygenases and their apocarotenoid products. Current Opinion in Plant Biology 9:315-321.

de Azevedo Neto AD, Prisco JT, Enéas-Filho J, de Abreu CEB, Gomes-Filho E (2006) Effect of salt stress on antioxidative enzymes and lipid peroxidation in leaves and roots of salt-tolerant and salt-sensitive maize genotypes. Environmental and Experimental Botany 56: 87-94.

Awasthi YC, Beutler E, Srivastava SK (1975) Purification and properties of human erythrocyte glutathione peroxidase. Journal of Biological Chemistry 250: 5144-5149 
Bandurska H, Stroiński A (2005) The effect of salicylic acid on barley response to water deficit. Acta Physiologiae Plantarum 27: 379-38.

Barrero JM, Rodriguez PL, Quesada V, Piqueras P, Ponce MR, Micul J L (2006) Both abscisic acid (ABA)-dependent and $\mathrm{ABA}$-independent pathway govern the induction of NCED3, AAO3 and ABA1 in response to salt stress. Plant Cell and Environment 29: 2000-2008.

Basantani M, Srivastava A (2007) Plant glutathione transferases-a decade falls short. Botany 85: 443-456.

Bianchi MW, Roux C, Vartanian N (2002) Drought regulation of GST8, encoding the Arabidopsis homologue of ParC/Nt107 glutathione transferase/peroxidase. Physiologia Plantarum 116: 96-105.

Blanco F, Salinas P, Cecchini NM, Jordana X, Van Hummelen P, Alvarez ME, Holuigue L (2009) Early genomic responses to salicylic acid in Arabidopsis. Plant Molecular Biology 70: 79-102.

Bombarely A, Menda N, Tecle IY, Buels RM, Strickler S, Fischer-York T, Pujar A, Leto J, Gosselin J, Mueller LA (2011) The sol genomics network (solgenomics.net): growing tomatoes using Perl. Nucleic Acids Research 39: D1149-D1155.

Borsani O, Valpuesta V, Botella MA (2001) Evidence for a role of salicylic acid in the oxidative damage generated by $\mathrm{NaCl}$ and osmotic stress in Arabidopsis seedlings. Plant Physiology 126: 1024-1030.

Bradford MM (1976) A rapid and sensitive method for the quantitation of microgram quantities of protein utilizing the principle of protein-dye binding. Analytical Biochemistry 72: 248-254.

Bray EA (2002) Classification of genes differentially expressed during water-deficit stress in Arabidopsis thaliana: An analysis using microarray and differential expression data. Annals of Botany 89: 803-811.

Camara B, Bouvier F (2004) Oxidative remodeling of plastid carotenoids. Archives of Biochemistry and Biophysics 430:16-21.

Cao Y, Zhang ZW, Xue LW, Du JB, Shang J, Xu F, Yuan S, Lin HH (2008) Lack of salicylic acid in Arabidopsis protects plants against moderate salt stress. Zeitschrift fur Naturforschung. C, Journal of Biosciences 64: 231-238.

Cartieaux F, Contesto C, Gallou A, Desbrosses G, Kopka J, Taconnat L, Renou JP, Touraine B (2008) Simultaneous interaction of Arabidopsis thaliana with Bradyrhizobium sp. strain ORS278 and Pseudomonas syringae pv. tomato DC3000 leads to complex transcriptome changes. Molecular Plant-Microbe Interactions 21: 244-259.

Che P, Gingerich DJ, Lall S, Howell SH (2002) Global and hormone-induced gene expression changes during shoot development in Arabidopsis. The Plant Cell Online 14: 27712785.

Chen HJ, Kuć J (1999) $\mathrm{Ca}^{2+}$-dependent excretion of salicylic acid in tobacco cell suspension culture. Botanical Bulletin of Academia Sinica 40.

Chen HJ, Hou WC, Kuć J, Lin YH (2001) $\mathrm{Ca}^{2+}$-dependent and $\mathrm{Ca}^{2+}$-independent excretion modes of salicylic acid in tobacco cell suspension culture. Journal of Experimental Botany 52: 1219-1226. 
Chen C, Huang IC, Liu MJ, Wang ZG, Chung SS, Hsieh HL (2007) Glutathione S-transferase interacting with far-red insensitive 219 is involved in phytochrome A-mediated signaling in Arabidopsis. Plant Physiology 143: 1189-1202.

Chen JH, Jiang HW, Hsieh EJ, Chen HY, Chien, CT, Hsieh HL, Lin TP (2012) Drought and salt stress tolerance of an arabidopsis glutathione S-transferase U17 knockout mutant are attributed to the combined effect of glutathione and abscisic acid. Plant Physiology 158: 340-351.

Chomczynski P, Sacchi N (1987) Single-step method of RNA isolation by acid guanidinium thiocyanate-phenol- chloroform extraction. Analytical Biochemistry 162:156-159.

Chua L, Shan X, Wang J, Peng W, Zhang G, Xie D (2010) Proteomics study of COI1-regulated proteins in Arabidopsis flower. Journal of Integrative Plant Biology 52: 410-419.

Colcombet J, Hirt H (2008) Arabidopsis MAPKs: a complex signalling network involved in multiple biological processes. Biochemical Journal 413: 217-226.

Cosio C, Dunand C (2009) Specific functions of individual class III peroxidase genes. Journal of Experimental Botany 60: 391-408.

Cowan A K (2000) Is abscisic aldehyde really the immediate precursor to stress-induced ABA? Trends in plant science 5: 191-192.

Csiszár J, Szabó M, Erdei L, Márton L, Horváth F, Tari I (2004) Auxin autotrophic tobacco callus tissues resists oxidative stress: the importance of glutathione S-transferase and glutathione peroxidase activities in auxin heterotrophic and autotrophic calli. Journal of Plant Physiology 161:691-699.

Csiszár J, Lantos E, Tari I, Madosa E, Wodala B, Vashegyi Á, Horváth F, Pécsváradi A, Szabó M, Bartha B, Gallé Á, Lazăr A, Coradini G, Staicu M, Postelnicu S, Mihacea S, Nedelea G, Erdei L (2007) Antioxidant enzyme activities in Allium species and their cultivars under water stress. Plant Soil and Environment 53: 517.

Csiszár J, Gallé Á, Horváth E, Dancsó P, Gombos M, Váry Zs, Erdei L, Györgyey J, Tari I (2012) Different peroxidase activities and expression of abiotic stress-related peroxidases in apical root segments of wheat genotypes with different drought stress tolerance under osmotic stress. Plant Physiology and Biochemistry 52: 119-129.

Csiszár J, Horváth E, Váry Z, Gallé Á, Bela K, Brunner S, Tari I (2014) Glutathione transferase supergene family in tomato: Salt stress-regulated expression of representative genes from distinct GST classes in plants primed with salicylic acid. Plant Physiology and Biochemistry 78: 15-26.

Cummins I, Cole DJ, Edwards R (1999) A role for glutathione transferases functioning as glutathione peroxidases in resistance to multiple herbicides in blackgrass. The Plant Journal 18: 285-292.

Dangl JL, Jones J D (2001) Plant pathogens and integrated defence responses to infection. Nature 411: 826-833.

Dat J, Vandenabeele S, Vranova E, Van Montagu M, Inze D, Van Breusegem F (2000) Dual action of the active oxygen species during plant stress responses. Cellular and Molecular Life Sciences 57: 779-795. 
Davies WJ, Kudoyarova G, Hartung W (2005) Long-distance ABA signaling and its relation to other signaling pathways in the detection of soil drying and the mediation of the plant's response to drought. Journal of Plant Growth Regulation 24: 285-295.

Dean JV, Mills JD (2004) Uptake of salicylic acid 2-O- $\beta$-D-glucose into soybean tonoplast vesicles by an ATP-binding cassette transporter-type mechanism. Physiologia Plantarum 120: 603-612.

De Gara L. 2004 Class III peroxidases and ascorbate metabolism in plants. Phytochemistry Reviews 3: 195-205.

DeRidder B P, Dixon DP, Beussman DJ, Edwards R, Goldsbrough PB (2002) Induction of glutathione S-transferases in Arabidopsis by herbicide safeners. Plant Physiology 130: 1497-1505.

DeRidder BP, Goldsbrough PB (2006) Organ-specific expression of glutathione Stransferases and the efficacy of herbicide safeners in Arabidopsis. Plant Physiology 140: 167-175.

Dhindsa RS, Plumb-Dhindsa P, Thorpe TA (1981) Leaf senescence: correlated with increased levels of membrane permeability and lipid peroxidation, and decreased levels of superoxide dismutase and catalase. Journal of Experimental Botany 32: 93-101.

Dixon DP, Cole DJ, Edwards R (1998) Purification, regulation and cloning of a glutathione transferase (GST) from maize resembling the auxin-inducible type-III GSTs. Plant Molecular Biology 36: 75-87.

Dixon DP, Lapthorn A, Edwards R (2002a) Plant glutathione transferases. Genome Biology 3.

Dixon DP, Davis BG, Edwards R (2002b) Functional divergence in the glutathione transferase superfamily in plants e identification of two classes with putative functions in redox homeostasis in Arabidopsis thaliana. The Journal of Biological Chemistry 277: 30859-30869.

Dixon DP, Hawkins T, Hussey PJ, Edwards R (2009) Enzyme activities and subcellular localization of members of the Arabidopsis glutathione transferasesuperfamily. Journal of Experimental Bototany 60: 1207-1218.

Dixon, D. P., Edwards, R. (2009). Selective binding of glutathione conjugates of fatty acid derivatives by plant glutathione transferases. The Journal of Biological Chemistry, 284: 21249-21256.

Dixon DP, Edwards R (2010) Glutathione transferases. The Arabidopsis Book/American Society of Plant Biologists 8.

Dixon DP, Skipsey M, Edwards R (2010) Roles for glutathione transferases in plant secondary metabolism. Phytochemistry 71: 338-350.

Durner J, Shah J, Klessig DF (1997) Salicylic acid and disease resistance in plants. Trends Plant Sci. 2: 266-274.

Droog F (1997) Plant glutathione S-transferases, a tale of theta and tau. Journal of Plant Growth Regulation 16: 95-107.

de Torres Zabala M, Bennett MH, Truman WH, Grant MR (2009) Antagonism between salicylic and abscisic acid reflects early host-pathogen conflict and moulds plant defence responses. The Plant Journal 59:375-386. 
Ederli L, Pasqualini S, Batini P, Antonielli M (1997) Photoinhibition and oxidative stress: effects on xanthophyll cycle, scavenger enzymes and abscisic content in tobacco plants. Journal of Plant Physiology 151: 422-428.

Edwards R, Dixon DP, Walbot V (2000) Plant glutathione S-transferases: enzymes with multiple functions in sickness and in health.Trends in Plant Science 5: 193-198.

Edwards R, Dixon DP, Lapthorn A (2002) Plant glutathione transferases. Genome Biology 3.

Edwards R, Dixon DP (2005) Plant glutathione transferases. Methods in Enzymology 401: 169-186.

Edwards R, Dixon DP, Skipsey M (2010) Roles for glutathione transferases in plant secondary metabolism. Phytochemistry 71: 338-350.

El-Tayeb MA (2005) Response of barley grains to the interactive effect of salinity and salicylic acid. Plant Growth Regulation 45: 215-224.

Eltayeb AE, Kawano N, Badawi GH, Kaminaka H, Sanekata T, Shibahara T, Inanaga S, Tanaka K (2007) Overexpression of monodehydroascorbate reductase in transgenic tobacco confers enhanced tolerance to ozone, salt and polyethylene glycol stresses. Planta 225: 1255-1264.

Endo A, Sawada Y, Takahashi H, Okamoto M, Ikegami K, Koiwai H, Seo M, Toyomasu T, Mitsuhashi W, Shinozaki K, Nakazono M, Kamiya Y, Koshiba T, Nambra E (2008) Drought induction of Arabidopsis 9-cis-epoxycarotenoid dioxygenase occurs in vascular parenchyma cells. Plant Physiol 147:1984-1993.

Enyedi AJ, Yalpani N, Silverman P, Raskin I (1992) Localization, conjugation, and function of salicylic acid in tobacco during the hypersensitive reaction to tobacco mosaic virus. Proceedings of the National Academy of Sciences 89: 2480-2484.

Forouhar F, Yang Y, Kumar D, Chen Y, Fridman E, Park S W, Chiang Y, Acton TB, Montelione GT, Pichersky E, Klessig DF, Tong L (2005) Structural and biochemical studies identify tobacco SABP2 as a methyl salicylate esterase and implicate it in plant innate immunity. Proceedings of the National Academy of Sciences of the United States of America 102: 1773-1778.

Foyer CH, Noctor G (2009) Redox regulation in photosynthetic organisms: signaling, acclimation, and practical implications. Antioxidants and Redox Signaling 11: 861905.

Gallé Á, Csiszár J, Benyó D, Laskay G, Leviczky T, Erdei L, Tari I (2013) Isohydric and anisohydric strategies of wheat genotypes under osmotic stress: Biosynthesis and function of ABA in stress responses. Journal of Plant Physiology 170: 1389-1399.

Gémes K, Poór P, Horváth E, Kolbert Zs, Szopkó D, Szepesi Á, Tari I (2011) Cross-talk between salicylic acid and $\mathrm{NaCl}$-generated reactive oxygen species and nitric oxide in tomato during acclimation to high salinity. Physiologia Plantarum 142: 179-192.

Gepstein S, Sabehi G, Carp MJ, Hajouj T, Nesher MFO, Yariv I, Dor C, Bassani M (2003) Large-scale identification of leaf senescence-associated genes. The Plant Journal 36: 629-642.

Gill SS, Tuteja N (2010) Reactive oxygen species and antioxidant machinery in abiotic stress tolerance in crop plants. Plant Physiology and Biochemistry 48: 909-930. 
Gong H, Jiao Y, Hu WW, Pua EC (2005) Expression of glutathione-S-transferase and its role in plant growth and development in vivo and shoot morphogenesis in vitro. Plant Molecular Biology 57: 53-66.

Gonzales-Guzman M, Apostolova N, Belles JM, Barrero JM, Piqueras P, Ponce R M, Micol JL, Serrano M, Rodriguez PL (2002) The short-chain alcohol dehydrogenase ABA2 catalyzes the conversion of xanthoxin to abscisic aldehyde. The Plant Cell 14: 18331846.

Gruhler A, Schulze WX, Matthiesen R, Mann M, Jensen ON (2005) Stable isotope labeling of Arabidopsis thaliana cells and quantitative proteomics by mass spectrometry. Molecular and Cellular Proteomics 4: 1697-1709.

Gunes A, Inal A, Alpaslan M, Eraslan F, Bagci EG, Cicek N (2007) Salicylic acid induced changes on some physiological parameters symptomatic for oxidative stress and mineral nutrition in maize (Zea mays L.) grown under salinity. Journal of Plant Physiology 164: 728-736.

Guóth A, Benyó D, Csiszár J, Gallé Á, Horváth F, Cseuz L, Erdei L, Tari I (2010) Relationship between osmotic stress-induced abscisic acid accumulation, biomass production and plant growth in drought tolerant and sensitive wheat genotypes. Acta Physiologia Plantarum 32: 719-727.

Habig WH, Pabst MJ, Jakoby WB (1974) Glutathione S-transferases. The first enzymatic step in mercapturic acid formation. Journal of Biological Chemistry 246: 7130-7139.

Haddadchi GR, Gerivani Z (2009) Effects of phenolic extracts of canola (Brassica napuse L.) on germination and physiological responses of soybean (Glycin max L.) seedlings. International Journal of Plant Production 3: 63-74.

Han Y, Chaouch S, Mhamdi A, Queval G, Zechmann B, Noctor GD (2012) Functional analysis of Arabidopsis mutants points to novel roles for glutathione in coupling $\mathrm{H}_{2} \mathrm{O}_{2}$ to activation of salicylic acid accumulation and signaling. Antioxidants and Redox Signaling 18: 2106-2121.

Hao L, Zhao Y, Jin D, Zhang L, Bi X, Chen H, Xu Q, Ma C, Li G (2012) Salicylic acidaltering Arabidopsis mutants response to salt stress. Plant and Soil 354: 81-95.

Harinasut P, Poonsopa D, Roengmongkol K, Charoensataporn R (2003) Salinity effects on antioxidant enzymes in mulberry cultivar. Science Asia 29: 109-113.

Hasegawa PM, Bressan RA, Zhu JK, Bohnert HJ (2000) Plant cellular and molecular responses to high salinity. Annual Review of Plant Physiology 51: 463-499.

Hayat Q, Hayat S, Irfan M, Ahmad A (2010) Effect of exogenous salicylic acid under changing environment: A review. Environmental and Experimental Botany 68: 14-25.

Horváth E, Janda T, Szalai G, Páldi E (2002) In vitro salicylic acid inhibition of catalase activity in maize: differences between the isozymes and a possible role in the induction of chilling tolerance. Plant Science 163: 1129-1135.

Horváth E, Szalai G, Janda T (2007) Induction of abiotic stress tolerance by salicylic acid signaling. Journal of Plant Growth Regulation 26: 290-300.

Huson DH, Richter DC, Rausch C, Dezulian T, Franz M, Rupp R (2007) Dendroscope: an interactive viewer for large phylogenetic trees. BMC Bioinformtics 8 . 
Iuchi S, Kobayashi M, Yamaguchi-Shinozaki K, Shinozaki K (2000) A stress-inducible gene for 9-cis- epoxycarotenoid dioxygenase involved in abscisic acid biosynthesis under water stress in drought-tolerant cowpea. Plant Physiology 123: 553-562.

Jaleel CA, Riadh K, Gopi R, Manivannan P, Ines J, Al-Juburi H, Chang-Xing Z, Hong-Bo S, Panneerselvam R (2009) Antioxidant defense responses: physiological plasticity in higher plants under abiotic constraints. Acta Physiologiae Plantarum 31: 427-436.

Jaspers P, Kangasjarvi J (2010) Reactive oxygen species in abiotic stress signaling. Physiologia Plantarum 138: 405-413.

Jayakannan M, Bose J, Babourina O, Rengel Z, Shabala S (2013) Salicylic acid improves salinity tolerance in Arabidopsis by restoring membrane potential and preventing saltinduced $\mathrm{K}^{+}$loss via a GORK channel. Journal of Experimental Botany 64: 2255-2268.

Jha B., Sharma A, Mishra A (2011). Expression of SbGSTU (tau class glutathione Stransferase) gene isolated from Salicornia brachiata in tobacco for salt tolerance. Molecular Biology Reports 38: 4823-4832.

Ji W, Zhu YM, Li Y, Yang LA, Zhao XW, Cai H, Bai X (2010) Over-expression of a glutathione S-transferase gene, GsGST, from wild soybean (Glycine soja) enhances drought and salt tolerance in transgenic tobacco. Biotechnology Letters 32: 1173-1179.

Jiang HW, Liu MJ, Chen IC, Huang CH, Chao LY, Hsieh HL (2010) A glutathione stransferase regulated by light and hormones participates in the modulation of arabidopsis seedling development. Plant Physiology 154: 1646-1658.

Joseph B, Jini D, Sujatha S (2010) Insight into the role of exogenous salicylic acid on plants grown under salt environment. Asian Journal of Crop Science 2: 226-235.

Joseph B, Jini D (2011) Development of salt stress-tolerant plants by gene manipulation of antioxidant enzymes. Asian Journal of Agricultural Research 5: 17-27.

Juan M, Rivero RM, Romero L, Ruiz JM (2005) Evaluation of some nutritional and biochemical indicators in selecting salt-resistant tomato cultivars. Environmental and Experimental Botany 54: 193-201.

Kampranis SC, Damianova R, Atallah M, Toby G, Kondi G, Tsichlis PN, Makris AM (2000) A novel plant glutathione S-transferase/peroxidase suppresses Bax lethality in yeast. The Journal of Biological Chemistry 275: 29207-29216.

Kanno Y, Jikumaru Y, Hanada A, Nambara E, Abrams SR, Kamiya Y, Seo M (2010) Comprehensive hormone profiling in developing Arabidopsis seeds: examination of the site of ABA biosynthesis, ABA transport and hormone interactions. Plant and Cell Physiology 51: 1988-2001.

Kawano T, Furuichi T, Muto S (2004) Controlled salicylic acid levels and corresponding signaling mechanisms in plants. Plant Biotechnology 21: 319-335.

Khan NA, Syeed S, Masood A, Nazar R, Iqba N (2010) Application of salicylic acid increases contents of nutrients and antioxidative metabolism in mungbean and alleviates adverse effects of salinity stress. International Journal of Plant Biology 1: e1.

Khan MIR, Asgher M, Khan NA (2014) Alleviation of salt-induced photosynthesis and growth inhibition by salicylic acid involves glycinebetaine and ethylene in mungbean (Vigna radiata L.). Plant Physiology and Biochemistry 80: 67-74. 
Kilili KG, Atanassova N, Vardanyan A, Clatot N, Al-Sabarna K, Kanellopoulos PN, Makris AM, Kampranis SC (2004) Differential roles of Tau class glutathione S-transferases in oxidative stress. The Journal of Biological Chemistry 279: 24540-24551.

Kim Y, Arihara J, Nakayama T, Nakayama N, Shimada S, Usui K (2004) Antioxidative responses and their relation to salt tolerance in Echinochloa oryzicola Vasing and Setaria virdis (L.) Beauv. Plant Growth Regulation 44: 87-92.

Kitamura S, Shikazono N, Tanaka A (2004) TRANSPARENT TESTA 19 is involved in the accumulation of both anthocyanins and proanthocyanidins in Arabidopsis. The Plant Journal 37: 104-114.

Kocsy G, Pál M, Soltész A, Szalai G, Boldizsár Á, Kovács V, Janda T (2011) Low temperature and oxidative stress in cereals. Acta Agronomica Hungarica 59: 169-189.

Krantev A, Yordanova R, Janda T, Szalai G, Popova L (2008) Treatment with salicylic acid decreases the effect of cadmium on photosynthesis in maize plants. Journal of Plant Physiology 165: 920-931.

Kumar S, Asif MH, Chakrabarty D, Tripathi RD, Dubey RS, Trivedi PK (2013) Differential expression of rice lambda class GST gene family members during plant growth, development, and in response to stress conditions. Plant Molecular Biology Reporter 31: 569-580.

Lan T, Yang ZL, Yang X, Liu YJ, Wang XR, Zeng QY (2009) Extensive functional diversification of the Populus glutathione S-transferase supergene family. The Plant Cell Online 21: 3749-3766.

Le Martret B, Poage M, Shiel K, Nugent GD, Dix PJ (2011) Tobacco chloroplast transformants expressing genes encoding dehydroascorbate reductase, glutathione reductase, and glutathione-S-transferase, exhibit altered anti-oxidant metabolism and improved abiotic stress tolerance. Plant Biotechnology Journal 9: 661-673.

Lee S, Kim SG, Park CM (2010) Salicylic acid promotes seed germination under high salinity by modulating antioxidant activity in Arabidopsis. New Phytologist 188: 626-637.

Lee K, Han KS, Kwon YS, Lee JH, Kim SH, Chung WS, Kim Y, Chun SS, Kim HK, Bae DW (2009) Identification of potential DREB2C targets in Arabidopsis thaliana plants overexpressing DREB2C using proteomic analysis. Molecules and Cells 28: 383-388.

Lee S, Park CM (2010) Modulation of reactive oxygen species by salicylic acid in Arabidopsis seed germination under high salinity. Plant Signaling and Behavior 5: 1534-1536.

Lefebvre V, North H, Frey A, Sotta B, Seo M, Okamoto M, Nambara E, Marion-Poll A (2006) Functional analysis of Arabidopsis NCED6 and NCED9 genes indicates that ABA synthesized in the endosperm is involved in the induction of seed dormancy. The Plant Journal 45: 309-319.

Lescot M, Dehais P, Thijs G, Marchal K, Moreau Y, Van de Peer Y, Rouze P, Rombauts S, (2002) PlantCARE, a database of plant cis-acting regulatory elements and a portal to tools for in silico analysis of promoter sequences. Nucleic Acids Research 30: 325327. 
Li J, Besseau S, Törönen P, Sipari N, Kollist H, Holm L, Palva ET (2013) Defense-related transcription factors WRKY70 and WRKY54 modulate osmotic stress tolerance by regulating stomatal aperture in Arabidopsis. New Phytologist 200: 457-472.

Li ZG, Xie LR, Li XJ (2015) Hydrogen sulfide acts as a downstream signal molecule in salicylic acid-induced heat tolerance in maize (Zea mays L.) seedlings. Journal of Plant Physiology 177: 121-127.

Lieberherr D, Wagner U, Dubuis PH, Métraux JP, Mauch F (2003) The rapid induction of glutathione S-transferases AtGSTF2 and AtGSTF6 by avirulent Pseudomonas syringae is the result of combined salicylic acid and ethylene signaling. Plant and Cell Physiology 44: 750-757.

Liu YJ, Han XM, Ren LL, Yang HL, Zeng QY (2013) Functional divergence of the glutathione S-transferase supergene family in Physcomitrella patens reveals complex patterns of large gene family evolution in land plants. Plant Physiology 161: 773-786.

Livak KJ, Schmittgen TD (2001) Analysis of relative gene expression data using real-time quantitative PCR and the $2^{-\Delta \Delta \mathrm{Ct}}$ method. Methods 25: 402-408.

Lovdal T, Lillo C, (2009) Reference gene selection for quantitative real-time PCR normalization in tomato subjected to nitrogen, cold, and light stress. Analytical Biochemistry 387: 238-242.

Lovelli S, Scopa A, Perniola M, Di Tommaso T, Sofo A (2012) Abscisic acid root and leaf concentration in relation to biomass partitioning in salinized tomato plants. Journal of Plant Physiology 169: 226-233.

Lu Z, Liu D, Liu S (2007) Two rice cytosolic ascorbate peroxidases differentially improve salt tolerance in transgenic Arabidopsis. Plant cell reports 26: 1909-1917.

Mahdavian K, Kalantari KM, Ghorbanli M (2007) The effect of different concentrations of salicylic acid on protective enzyme activities of pepper (Capsicum annuum L.) plants. Pakistan journal of biological sciences: PJBS 10: 3162-3165.

Mandal S, Mallick N, Mitra A (2009) Salicylic acid-induced resistance to Fusarium oxysporum f. sp. lycopersici in tomato. Plant Physiology and Biochemistry 47: 642649.

Mang HG, Kang EO, Shim JH, Kim SY, Park KY, Kim YS, Park KY, Kim YS, Bahk YY, Kim WT (2004) A proteomic analysis identifies glutathione S-transferase isoforms whose abundance is differentially regulated by ethylene during the formation of early root epidermis in Arabidopsis seedlings. Biochimica et Biophysica Acta (BBA)-Gene Structure and Expression 1676: 231-239.

Marrs KA (1996) The function and regulation of glutathione S-transferases in plants. Annual Review of Plant Physiology 47: 127-158.

Masclaux-Daubresse C, Purdy S, Lemaitre T, Pourtau N, Taconnat L, Renou JP, Wingler A (2007) Genetic variation suggests interaction between cold acclimation and metabolic regulation of leaf senescence. Plant Physiology 143: 434-446.

Menges M, Hennig L, Gruissem W, Murray JA (2002) Cell cycle-regulated gene expression inArabidopsis. Journal of Biological Chemistry 277: 41987-42002. 
Métraux JP, Signer H, Ryals J, Ward E, Wyss-Benz M, Gaudin J, Raschdorf K, Schmid E, Blum W, Inverardi B.(1990).Increase in salicylic acid at the onset of systemic acquired resistance in cucumber. Science 250: 1004-1006.

Métraux JP (2001) Systemic acquired resistance and salicylic acid: current state of knowledge. European Journal of Plant Pathology 107: 13-18.

Mezzari MP, Walters K, Jelínkova M, Shih MC, Just CL, Schnoor JL (2005) Gene expression and microscopic analysis of Arabidopsis exposed to chloroacetanilide herbicides and explosive compounds. A phytoremediation approach. Plant Physiology 138: 858-869.

Miller G, Suzuki N, Ciftci-Yilmaz S, Mittler R (2010) Reactive oxygen species homeostasis and signalling during drought and salinity stresses. Plant, Cell and Environment 33: 453-467.

Min X, Okada K, Brockmann B, Koshiba T, Kamiya Y (2000) Molecular cloning and expression patterns of three putative functional aldehyde oxidase genes and isolation of two aldehyde oxidase pseudogenes in tomato. Biochimica et Biophysica Acta (BBA)-Gene Structure and Expression 1493: 337-341.

Mittler R (2002) Oxidative stress, antioxidants and stress tolerance. Trends Plant Sci. 7: 405410.

Mittler R, Vanderauwera S, Gollery M, Van Breusegem F (2004) Reactive oxygen gene network of plants. Trends in Plant Science 9: 490-498.

Mittova V, Tal M, Volokita M, Guy M (2002) Salt stress induces up-regulation of an efficient chloroplast antioxidant system in the salt-tolerant wild tomato species Lycopersicon pennellii but not in the cultivated species. Physiologia Plantarum 115: 393-400.

Miura K, Tada Y (2014) Regulation of water, salinity, and cold stress responses by salicylic acid. Frontiers in Plant Science 5.

Miura K, Okamoto H, Okuma E, Shiba H, Kamada H, Hasegawa PM, Murata Y (2013) SIZ1 deficiency causes reduced stomatal aperture and enhanced drought tolerance via controlling salicylic acid-induced accumulation of reactive oxygen species in Arabidopsis. The Plant Journal 73: 91-104.

Moons A (2003) Osgstu3 and osgtu4, encoding tau class glutathione S-transferases, are heavy metal-and hypoxic stress-induced and differentially salt stress-responsive in rice roots. FEBS letters 553: 427-432.

Moore AL, Albury MS, Crichton PG, Affourtit C (2002) Function of the alternative oxidase: is it still a scavenger? Trends in Plant Science 7: 478-481.

Mou Z, Fan W, Dong X (2003) Inducers of plant systemic acquired resistance regulate NPR1 function through redox changes. Cell 113: 935-944.

Mulholland BJ, Taylor IB, Jackson AC, Thompson AJ (2003) Can ABA mediate response of salinity stressed tomato. Environmental and Experimental Botany 50: 17-28.

Munns R (2005) Genes and salt tolerance: bringing them together. New Phytologist 167: 645663.

Munns M, Tester M (2008) Mechanisms of Salinity Tolerance. Annual Reviews of Plant Biology 59: 651-81.

Munns R (2002) Comparative physiology of salt and water stress. Plant Cell and Environment 25: 239-250. 
Murashige T, Skoog F (1962) A revised medium for rapid growth and bio assays with tobacco tissue cultures. Physiologia Plantarum 15: 473-497.

Ndimba BK, Chivasa S, Simon WJ, Slabas AR (2005) Identification of Arabidopsis salt and osmotic stress responsive proteins using two-dimensional difference gel electrophoresis and mass spectrometry. Proteomics 5: 4185-4196.

Noctor G, Gomez L, Vanacker H, Foyer CH (2002) Interactions between biosynthesis, compartmentation and transport in the control of glutathione homeostasis and signalling. Journal of Experimental Botany 53: 1283-1304.

Noctor G, Foyer CH (1998) Ascorbate and glutathione: keeping active oxygen under control. Annual Review of Plant Biology 49: 249-279.

Noreen S, Ashraf M, Hussain M, Jamil A (2009) Exogenous application of salicylic acid enhances antioxidative capacity in salt stressed sunflower (Helianthus annuus L.) plants. Pakistan Journal of Botany 41: 473-479.

Noctor G, Queval G, Mhamdi A, Chaouch S, Foyer CH (2011) Glutathione. The Arabidopsis Book/American Society of Plant Biologists 9.

Nutricati E, Miceli A, Blando F, De Bellis L (2006) Characterization of two Arabidopsis thaliana glutathione S-transferases. Plant Cell Reports 25: 997-1005.

Omarov R, Dräger D, Tischner R, Lips H (2003) Aldehyde oxidase isoforms an subunit composition in roots of barley as affected by ammonium and nitrate. Physiolgia Plantarum 117: 337-342.

Orellana S, Yanez M, Espinoza A, Verdugo I, Gonzalez E, Ruiz-Lara S, Casaretto JA (2010) The transcription factor SIAREB1 confers drought, salt stress tolerance and regulates biotic and abiotic stress-related genes in tomato. Plant, Cell and Environment 33: 2191-2208.

Ori N, Eshed Y, Pinto P, Paran I, Zamir D, Fluhr R (1997) TAO1, a representative of molybdenum cofactor containing hydroxylases of tomato. Journal of Biological Chemistry 272: 1019-1025.

Ouyang B, Yang T, Li H, Zhang L, Zhang Y, Zhang J, Fei Z, Ye Z (2007) Identification of early salt stress response genes in tomato root by suppression subtractive hybridization and microarray analysis. Journal of Experimental Botany 58: 507-520.

Pál M, Szalai G, Kovács V, Gondor OK, Janda T (2013) Salicylic acid-mediated abiotic stress tolerance. In Salicylic Acid (pp. 183-247). Springer Netherlands.

Palma F, Lluch C, Iribarne,C, García-Garrido JM, Tejera García NA (2009) Combined effect of salicylic acid and salinity on some antioxidant activities, oxidative stress and metabolite accumulation in Phaseolus vulgaris. Plant Growth Regulation 58: 307-316.

Papdi Cs, Ábrahám E, Joseph MP, Popescu C, Koncz Cs, Szabados L (2008) Functional identification of Arabidopsis stress regulatory genes using the controlled cDNA overexpression system. Plant Physiology 147: 528-542.

Parida AK, Das AB (2005) Salt tolerance and salinity effects on plants: a review. Ecotoxicology and Environmental Safety 60: 324-349.

Park S W, Kaimoyo E, Kumar D, Mosher S, Klessig D F (2007) Methyl salicylate is a critical mobile signal for plant systemic acquired resistance. Science 318: 113-116. 
Passardi F, Longet D, Penel C, Dunand C (2004) The class III peroxidase multigenic in land plants family in rice and its evolution. Phytochemistry 65: 1879-1893.

Prashanth SR, Sadhasivam V, Parida A (2008) Over expression of cytosolic copper/zinc superoxide dismutase from a mangrove plant Avicennia marina in indica Rice var Pusa Basmati-1 confers abiotic stress tolerance.Transgenic Research 17: 281-291.

Pető A, Lehotai N, Feigl G, Tugyi N, Ördög A, Gémes K, Tari I, Erdei L, Kolbert Zs (2013) Nitric oxide contributes to copper tolerance by influencing ROS metabolism in Arabidopsis. Plant Cell Reports 32: 1913-1923.

Poór P, Gémes K, Horváth F, Szepesi Á, Simon ML, Tari I (2011) Salicylic acid treatment via the rooting medium interferes with stomatal response, $\mathrm{CO}_{2}$ fixation rate and carbohydrate metabolism in tomato, and decreases harmful effects of subsequent salt stress. Plant Biology 13: 105-114.

Potters G, Horemans N, Jansen MAK (2010) The cellular redox state in plant stress biology a charging concept. Plant Physiology and Biochemistry 48: 292-300.

Ramel F, Mialoundama AS, Havaux M. (2012) Nonenzymic carotenoid oxidation and photooxidative stress signalling in plants. Journal of Experimental Botany 63: 695709.

Rao MV, Davis KR (1999) Ozone-induced cell death occurs via two distinct mechanisms in Arabidopsis: the role of salicylic acid. The Plant Journal 17: 603-614.

Raskin I (1992) Role of salicylic acid in plants. Annual Review of Plant Physiology 43: 439463.

Rasmussen J B, Hammerschmidt R, Zook MN (1991) Systemic induction of salicylic acid accumulation in cucumber after inoculation with Pseudomonas syringae pv syringae. Plant Physiology 97: 1342-1347.

Rivas-San Vicente M, Plasencia J (2011) Salicylic acid beyond defence: its role in plant growth and development. Journal of Experimental Botany 62: 3321-3338.

Roxas VP, Lodhi SA, Garrett DK, Mahan JR, Allen RD (2000) Stress tolerance in transgenic tobacco seedlings that overexpress glutathione S-transferase/glutathione peroxidase. Plant and Cell Physiology 41: 1229-1234.

Sagi M, Omarov RT, Lips SH (1998) The Mo-hydroxylases xanthine dehydrogenase and aldehyde oxidase in ryegrass as affected by nitrogen and salinity. Plant Science 135: 125-135.

Sahu GK, Sabat SC (2011) Changes in growth, pigment content and antioxidants in the root and leaf tissues of wheat plants under the influence of exogenous salicylic acid. Brazilian Journal of Plant Physiology 23: 209-218.

Sappl PG, Onate-Sanchez L, Singh KB, Millar AH (2004) Proteomic analysis of glutathione S-transferases ofArabidopsis thaliana reveals differential salicylic acid-induced expression of the plant-specific phi and tau classes. Plant Molecular Biology 54: 205219.

Sappl PG, Carroll AJ, Clifton R, Lister R, Whelan J, Millar AH, Singh KB (2009) The Arabidopsis glutathione transferase gene family displays complex stress regulation and co-silencing multiple genes results in altered metabolic sensitivity to oxidative stress. The Plant Journal 58: 53-68. 
Sarry JE, Kuhn L, Ducruix C, Lafaye A, Junot C, Hugouvieux V, Jourdain A, Bastien O, Fievet JB, Vailhen D, Amekraz B, Moulin C, Ezan E, Garin J, Bourguignon J (2006) The early responses of Arabidopsis thaliana cells to cadmium exposure explored by protein and metabolite profiling analyses. Proteomics 6: 2180-2198.

Schafer FQ, Buettner GR (2001) Redox environment of the cell as viewed through the redox state of the glutathione disulfide/glutathione couple. Free Radical Biology and Medicine 30: 1191-1212.

Schwartz SH, Zeevaart JAD (2010) Abscisic acid biosynthesis and metabolism. Plant Hormones B 137-155.

Semane B, Dupae J, Cuypers A, Noben JP, Tuomainen M, Tervahauta A, Kärenlampi S, Van Belleghem F, Smeets K, Vangronsveld J (2010) Leaf proteome responses of Arabidopsis thaliana exposed to mild cadmium stress. Journal of Plant Physiology 167: 247-254.

Senaratna T, Touchell D, Bunn E, Dixon K (2000) Acetyl salicylic acid (Aspirin) and salicylic acid induce multiple stress tolerance in bean and tomato plants. Plant Growth Regulation 30: 157-161.

Seki M, Narusaka M, Ishida J, Nanjo T, Fujita M, Oono Y, Kamiya A, Nakajima M, Enju A, Sakurai T, Satou M, Akiyama K, Taji T, Shinozaki KY, Carninci P, Kawai J, Hayashizaki Y, Shinozaki K (2002) Monitoring the expression profiles of 7000 Arabidopsis genes under drought, cold and high-salinity stresses using a full-length cDNA microarray. The Plant Journal 31: 279-292.

Sekmen HA, Türkan İ, Takio S (2007) Differential responses of antioxidative enzymes and lipid peroxidation to salt stress in salt-tolerant Plantago maritima and salt-sensitive Plantago media. Physiologia Plantarum 131: 399-411.

Seo M, Peeters AJM, Koiwai H, Oritani T, Marion- Poll A, Zeevaart J A D, Koornneef M, Kamiya Y, Koshiba T (2000) The Arabidopsis aldehyde oxidase 3 (AAO3) gene product catalyze the final step in abscisic acid biosythesis in leaves. Proceedings of the National Academy of Sciences 97: 12908- 12913.

Seo M, Koshiba T (2002) Complex regulation of ABA biosynthesis in plants. Trends in Plant Science 7: 41-48.

Seo M, Aoki H, Koiwai H, Kamiya Y, Nambara E, Koshiba T (2004) Comparative study on the Arabidopsis aldehyde oxidase gene $(A A O)$ family revealed a major role of $A A O 3$ in ABA biosynthesis in seeds. Plant and Cell Physiology 45: 1694-1703.

Seo PJ, Park CM (2010) MYB96-mediated abscisic acid signals induce pathogen resistance response by promoting salicylic acid biosynthesis in Arabidopsis. New Phytologist 186: 471-483.

Shabala S (2009) Salinity and programmed cell death: unravelling mechanisms for ion specific signalling. Journal of Experimental Botany 60: 709-712.

Shirasu K, Nakajima H, Rajashekar K, Dixon RA, Lamb C (1997) Salicylic acid potentiates an agonist-dependent gain control that amplifies pathogen signal in the activation of defense mechanisms. The Plant Cell 9: 261-270. 
Shakirova FM, Sakhabutdinova AR, Bezrukova MV, Fatkhutdinova RA, Fatkhutdinova DR (2003) Changes in the hormonal status of wheat seedlings induced by salicylic acid and salinity. Plant Science 164: 317-322.

Shalata A, Neumann PM (2001) Exogenous ascorbic acid (vitamin C) increases resistance to salt stress and reduces lipid peroxidation. Journal of Experimental Botany 52: 22072211.

Sharma R, Sahoo A, Devendran R, Jain M (2014) Over-expression of a rice tau class glutathione S-transferase gene improves tolerance to salinity and oxidative stresses in Arabidopsis. PloS One 9: e92900.

Simaei M, Khavari-Nejad RA, Saadatmand S, Bernard F, Fahimi H (2011) Effects of salicylic acid and nitric oxide on antioxidant capacity and proline accumulation in Glycine max L. treated with $\mathrm{NaCl}$ salinity. African Journal of Agricultural Research 6: 3775-3782.

Slaymaker DH, Navarre DA, Clark D, del Pozo O, Martin GB, Klessig DF (2002) The tobacco salicylic acid-binding protein 3 (SABP3) is the chloroplast carbonic anhydrase, which exhibits antioxidant activity and plays a role in the hypersensitive defense response. Proceedings of the National Academy of Sciences 99: 11640-11645.

Smith AP, Nourizadeh SD, Peer WA, Xu J, Bandyopadhyay A, Murphy AS, Goldsbrough PB (2003) Arabidopsis AtGSTF2 is regulated by ethylene and auxin, and encodes a glutathione S-transferase that interacts with flavonoids. The Plant Journal 36: 433442.

Srivastava MK, Dwivedi UN (1998) Salicylic acid modulates glutathione metabolism in pea seedlings. Journal of Plant Physiology 153: 409-414.

Sumithra K, Jutur PP, Carmel BD, Reddy AR (2006) Salinity-induced changes in two cultivars of Vigna radiata: responses of antioxidative and proline metabolism. Plant Growth Regulation 50: 11-22.

SunW, Xu XN, Zhu HS, Liu AH, Liu L, Li JM, Hua XJ (2010) Comparative transcriptomic profiling of a salt-tolerant wild tomato species and a saltsensitive tomato cultivar. Plant and Cell Physiology 51: 997-1006.

Szepesi Á, Csiszár J, Bajkán S, Gémes K, Horváth F, Erdei L, Deér AK, Simon ML, Tari I (2005) Role of salicylic acid pre-treatment on the acclimation of tomato plants to saltand osmotic stress. Acta Biologica Szegediensis 49: 123-125.

Szepesi Á, Csiszár J, Gallé Á, Gémes K, Poór P, Tari I (2008) Effects of long-term salicylic acid pre-treatment on tomato (Lycopersicon esculentum MILL. L.) salt stress tolerance: changes in glutathione S-transferase activities and anthocyanin contents. Acta Agronomica Hungarica 56: 129-138.

Szepesi Á, Csiszár J, Gémes K, Horváth E, Horváth F, Simon ML, Tari I (2009) Salicylic acid improves acclimation to salt stress by stimulating abscisic aldehyde oxidase activity and abscisic acid accumulation, and increases $\mathrm{Na}^{+}$content in leaves without toxicity symptoms in Solanum lycopersicum L. Journal of Plant Physiology 166: 914-925.

Simkin AJ, Schwatz SH, Auldridge M, Taylor MG, Klee HJ (2004) The tomato carotenoid cleavage dioxygenase genes contribute to the formation of the flavor volatiles $\beta$ ionone, pseudoionone, and geranylacetone. The Plant Journal 40: 882-892. 
Stevens J, Senaratna T, Sivasithamparam K (2006) Salicylic acid induces salinity tolerance in tomato (Lycopersicon esculentum cv. Roma): associated changes in gas exchange, water relations and membrane stabilisation. Plant Growth Regulation 49: 77-83.

Sorin C, Negroni L, Balliau T, Corti H, Jacquemot MP, Davanture M, Sandberg G, Zivy M, Bellini C (2006) Proteomic analysis of different mutant genotypes of Arabidopsis led to the identification of 11 proteins correlating with adventitious root development. Plant Physiology 140: 349-364.

Syeed S, Anjum NA, Nazar R, Iqbal N, Masood A, Khan NA (2011) Salicylic acid-mediated changes in photosynthesis, nutrients content and antioxidant metabolism in two mustard (Brassica juncea L.) cultivars differing in salt tolerance. Acta Physiologiae Plantarum 33: 877-886.

Tamura K, Peterson D, Peterson N, Stecher G, Nei M, Kumar S (2011) MEGA5: molecular evolutionary genetics analysis using maximum likelihood, evolutionary distance, and maximum parsimony methods. Molecular Biology and Evolution 28: 2731-2739.

Taşgın E, Atıcı Ö, Nalbantoğlu B, Popova L P (2006) Effects of salicylic acid and cold treatments on protein levels and on the activities of antioxidant enzymes in the apoplast of winter wheat leaves. Phytochemistry 67: 710-715.

Tari I, Csiszár J, Szalai G, Horváth F, Pécsváradi A, Kiss G, Szepesi Á, Szabó M, Erdei L (2002) Acclimation of tomato plants to salinity stress after a salicylic acid pretreatment. Acta Biologica Szegediensis 46: 55-56.

Tari I, Csiszár J, Horváth E, Poór P, Takács Z, Szepesi Á (2015) Alleviation of the adverse effect of salt stress in tomato by salicylic acid shows time- and organ-specific antioxidant response. Acta Biologica Cracoviensia series Botany (doi/10.1515/abcsb2015-0008)

Tian M, von Dahl CC, Liu P-P, Friso G, van Wijk KJ, Klessig DF (2012) The combined use of photoaffinity labeling and surface plasmon resonance-based technology identifies multiple salicylic acid-binding proteins. The Plant Journal 72: 1027-1038.

Thatcher LF, Carrie C, Andersson CR, Sivasithamparam K, Whelan J, Singh KB (2007) Differential gene expression and subcellular targeting of Arabidopsis glutathione $\mathrm{S}$ transferase F8 is achieved through alternative transcription start sites. Journal of Biological Chemistry 282: 28915-28928.

Thompson JD, Higgins DG, Gibson TJ (1994) Clustal-W e improving the sensitivity of progressive multiple sequence alignment through sequence weighting, positionspecific gap penalties and weight matrix choice. Nucleic Acids Research 22: 4673 4680 .

Thompson AJ, Jackson AC, Parker RA, Morpeth DR, Burbidge A, Taylor IB (2000) Abscisic acid biosythesis in tomato: regulation of zeaxanthin epoxidase and 9-cisepoxycarotenoid dioxygenase mRNAs by light/dark cycles, water stress and abscisic acid. Plant Molecular Biology 42: 833-845.

Tung SA, Smeeton R, White CA, Black CR, Taylor IB, Hilton HW, Thompson JA (2008) Over-expression of LeNCED1 in tomato (Solanum lycopersicum L.) with the rbcS3C promoter allows recovery of lines that accumulate very high levels of abscisic acid and exhibit severe phenotypes. Plant Cell and Environment 31: 968-981. 
Upadhyaya A, Sankhla D, Davis TD, Sankhla N, Smith BN (1985) Effect of paclobutrazol on the activities of some enzymes of activated oxygen metabolism and lipid peroxidation in senescing soybean leaves. Journal of Plant Physiology 121: 453-461

Van Breusegem F, Bailey-Serres J, Mittler R (2008) Unraveling the tapestry of networks involving reactive oxygen species in plants. Plant Physiology 147: 978-984.

Velikova V, Yordanov I, Edreva A (2000) Oxidative stress and some antioxidant systems in acid raintreated bean plants. Protective role of exogenous polyamines. Plant Science 151: 59-66.

Vital SA, Fowler RW, Virgen A, Gossett DR, Banks SW, Rodriguez J (2008) Opposing roles for superoxide and nitric oxide in the $\mathrm{NaCl}$ stress-induced upregulation of antioxidant enzyme activity in cotton callus tissue. Environmental and Experimental Botany 62: 60-68.

Vlot AC, Dempsey DMA, Klessig DF (2009) Salicylic acid, a multifaceted hormone to combat disease. Annual Review of Phytopathology 47: 177-206.

Wagner U, Edwards R, Dixon DP, Mauch F (2002) Probing the diversity of the Arabidopsis glutathione S-transferase gene family. Plant Molecular Biology 49: 515-532.

Wilkinson S, Davies WJ (2002) ABA-based chemical signalling: the co-ordination of responses to stress in plants. Plant, Cell and Environment 25: 195-210.

Wilkinson S, Davies WJ (2010) Drought, ozone, ABA and ethylene: new insights from cell to plant to community. Plant, Cell and Environment 33: 510-525.

Willekens H, Chamnongpol S, Davey M, Schraudner M, Langebartels C, Van Montagu M, Van Camp W (1997) Catalase is a sink for H2O2 and is indispensable for stress defence in C3 plants. The EMBO Journal 16: 4806-4816.

Xiong L, Zhu J-K (2003) Regulation of abscisic acid biosynthesis. Plant Physiology 133: 2936.

Xu E, Brosché M (2014) Salicylic acid signaling inhibits apoplastic reactive oxygen species signaling. BMC Plant Biology 14: 155.

Yang X, Sun W, Liu JP, Liu YJ, Zeng QY (2009) Biochemical and physiological characterization of a tau class glutathione transferase from rice (Oryza sativa). Plant Physiology and Biochemistry 47: 1061-1068.

Yasuda M, Ishikawa A, Jikumaru Y, Seki M, Umezawa T, Asami T, Maruyama-Nakashita A, Kudo T, Shinozaki K, Yoshuda S, Nakashita H (2008) Antagonistic interaction between systemic acquired resistance and the abscisic acid-mediated abiotic stress response in Arabidopsis. Plant Cell Online 20: 1678-1692.

Yoon HS, Lee H, Lee IA, Kim KY, Jo J (2004) Molecular cloning of the monodehydroascorbate reductase gene from Brassica campestris and analysis of its mRNA level in response to oxidative stress. Biochimica et Biophysica Acta (BBA)Bioenergetics 1658: 181-186.

Zdunek E, Lips SH (2001) Transport and accumulation rates of abscisic acid and aldehyde oxidase activity in Pisum sativum L. in response to suboptimal growth conditions. Journal of Experimental Botany 52: 1269-1276. 
Zdunek-Zastocka E (2008) Molecular cloning, characterization and expression analysis of three aldehyde oxidase genes from Pisum sativum L. Plant Physiology and Biochemistry 46: 19-28.

Zhang H, Han B, Wang T, Chen S, Li H, Zhang Y, Dai S (2012) Mechanisms of plant salt sesponse: insights from proteomics. Journal of Proteome Research 11: 4967.

Zhao F, Zhang H (2006) Expression of Suaeda salsa glutathione S-transferase in transgenic rice resulted in a different level of abiotic stress resistance. The Journal of Agricultural Science 144: 547-554.

Zhao X, Tan HJ, Liu YB, Li XR, Chen GX (2009) Effect of salt stress on growth and osmotic regulation in Thellungiella and Arabidopsis callus. Plant Cell, Tissue and Organ Culture 98: 97-103.

Zhu JK (2001) Plant salt tolerance. Trends in Plant Science 6: 66-71.

Zhu JK (2003) Regulation of ion homeostasis under salt stress. Current Opinion in Plant Biology 6: 441-445. 


\section{Publikációs lista}

\section{Tudományos közlemények referált folyóiratokban}

(A *-gal jelölt közlemények közvetlenül kapcsolódnak a PhD értekezéshez)

*Horváth E, Csiszár J, Gallé Á, Poór P, Szepesi Á, Tari I (2015) Hardening with salicylic acid induces concentration-dependent changes in abscisic acid biosynthesis of tomato under salt stress. Journal of Plant Physiology 183: 54-63.

IF (2014): 2,557

*Horváth E, Bela K, Papdi Cs, Gallé Á, Szabados L, Tari I, Csiszár J (2015) The role of Arabidopsis glutathione transferase F9 gene under oxidative stress in seedlings. Acta Biologica Hungarica 66 (4). (accepted)

IF (2014): 0,589

Tari I, Csiszár J, Horváth E, Poór P, Takács Z, Szepesi Á (2015) Alleviation of the adverse effect of salt stress in tomato by salicylic acid shows time- and organ-specific antioxidant response. Acta Biologica Cracoviensia Series Botanica (doi/10.1515/abcsb-20150008).

IF (2014): 0,662

Bela K, Horváth E, Gallé Á, Szabados L,Tari I, Csiszár J (2015) Plant glutathione peroxidases: Emerging role of the antioxidant enzymes in plant development and stress responses. Journal of Plant Physiology 176: 192-201.

IF (2014): 2,557

*Csiszár J, Horváth E, Váry Zs, Gallé Á, Bela K, Brunner Sz, Tari I (2014) Glutathione transferase supergene family in tomato: salt stress-regulated expression of representative genes from distinct GST classes in plants primed with salicylic acid. Plant Physiology and Biochemistry 78: 15-26.

IF: $\mathbf{2 , 7 5 6}$

Csiszár J, Gallé Á, Horváth E, Dancsó P, Gombos M, Váry Zs, Erdei L, Györgyey J, Tari I (2012) Different peroxidase activities and expression of abiotic stress-related peroxidases in apical root segments of wheat genotypes with different drought stress tolerance under osmotic stress. Plant Physiology and Biochemistry 52: 119-129. IF: 2,775

*Horváth E, Gallé Á, Szepesi Á, Tari I, Csiszár J (2011) Changes in aldehyde oxidase activity and gene expression in Solanum lycopersicum L. shoots under salicylic acid pretreatment and subsequent salt stress. Acta Biologica Szegediensis 55: 83-85. 
Gémes K, Poór P, Horváth E, Kolbert Zs, Szopkó D, Szepesi Á, Tari I (2011) Cross-talk between salicylic acid and $\mathrm{NaCl}$-generated reactive oxygen species and nitric oxide in tomato during acclimation to high salinity. Physiologia Plantarum 142: 179-192.

\section{IF: 3,112}

*Csiszár J, Váry Zs, Horváth E, Gallé Á, Tari I (2011) Role of glutathione transferases in the improved acclimation to salt stress in salicylic acid-hardened tomato. Acta Biologica Szegediensis 55: 67-68.

Horváth E (2009) Protoplast isolation from Solanum lycopersicum L. leaf tissues and their response to short-term $\mathrm{NaCl}$ treatment. Acta Biologica Szegediensis 53: 83-86.

Szepesi Á, Csiszár J, Gémes K, Horvath E, Horvath F, Simon ML, Tari I (2009) Salicylic acid improves acclimation to salt stress by stimulating abscisic aldehyde oxidase activity and abscisic acid accumulation, and increases $\mathrm{Na}^{+}$content in leaves without toxicity symptoms in Solanum lycopersicum L. Journal of Plant Physiology 166: 914-925.

\section{IF: 2,500}

Szepesi Á, Poór P, Gémes K, Horváth E, Tari I (2008) Influence of exogenous salicylic acid on antioxidant enzyme activities in the roots of salt stressed tomato plants. Acta Biologica Szegediensis 52: 199-200.

Benyújtott kézirat (2015): Horváth E, Brunner Sz, Bela K, Papdi Cs, Szabados L, Tari I, Csiszár J. Exogenous salicylic acid-triggered changes in the glutathione transferases and peroxidases are key factors in the successful salt stress acclimation of Arabidopsis thaliana.

\section{Konferencia kiadványban megjelent absztraktok}

\section{Konferencia elöadások}

Csiszár J, Bela K, Horváth E, Gallé Á, Brunner Sz, Szabados L, Ayaydin F, Tari I (2015) Oxidative stress responses - The redox regulated aspect and molecular investigations. HUSRB/1203/221/173 "PLANTTRAIN" Joint development of higher education and training programmes in plant biology in support of knowledge-based society, Opening Conference. 2015.04.20-2015.04.21. Szeged, Magyarország. Book of Abstracts p. 10.

Tari I, Borbély P, Csiszár J, Gémes K, Horváth E, Kovács J, Poór P, Szepesi Á, Takács Z (2014) Sóstressz tolerancia fokozása szalicilsavval paradicsomban: az abszcizinsav szerepe. Paál Árpádtól a molekuláris növénybiológiáig: Tudományos ülés Paál Árpád születésének 
125. és intézetigazgatói kinevezésének 85. évfordulója alkalmából. 2014.12.16. Budapest, Magyarország. p. 55 (ISBN:978-963-284-561-6)

Csiszár J, Brunner Sz, Bela K, Horváth E, Lehotai N, Feigl G, Papdi Cs, Perez I, Kovács H, Szabados L, Ayaydin F (2014) Redox homeostasis in plants - its significance, components and evaluation. 11th Congress of the Hungarian Society of Plant Biology. 2014.09.272014.09.29. Szeged, Magyarország. Book of Abstracts S1-07.

Horváth E, Kolbert Zs, Lehotai N, Feigl G, Tari I, Erdei L (2013) Role of reactive oxygen and nitrogen species in poplar plants during abiotic stresses. IPA OXIT Conference Oxidative stress tolerance in plants: from models to trees HUSRB/1002/214/036: 2013.11.14. Novi Sad, Szerbia. Book of Abstracts p. 6.

Horváth E, Brunner Sz, Bela K, Csenki D, Papdi Cs, Szabados L, Tari I, Csiszár J (2013) Hosszútávú szalicilsav kezelés hatásának vizsgálata lúdfü növényekben. A Magyar Szabadgyök-Kutató Társaság VII. Konferenciája. 2013.08.29-2013.08.31. Debrecen, Magyarország. Program és Absztraktok p. 19.

Horváth E, Kolbert Zs, Lehotai N, Feigl G, Tari I, Erdei L (2012) Role of reactive oxygen- and nirogen species in poplar plants during zinc, copper and polyethylene glycol treatments. HUSRB/1002/214/036 "OXIT" Characterization and oxidative stress tolerance in plants: from models to trees. Interim conference. 2012.11.20. Szeged, Magyarország. Programme and Abstracts p. 11.

Tari I, Gémes K, Horváth E, Poór P, Szepesi Á, Csiszár J (2011) Regulation of antioxidant defence systems and abscisic acid biosynthesis by salicylic acid in tomato roots. 10th International Conference on Reactive Oxygen and Nitrogen Species in Plants. 2011.07.05-2011.07.08. Budapest, Magyarország. p. 37.

Tari I, Gémes K, Horváth E, Poór P, Szepesi Á, Csiszár J (2011) A szalicilsav szerepe a paradicsom sóstressz rezisztenciájának fokozásában: interakció az abszcizinsav és az etilén jelátviteli folyamataiban. A Magyar Növénybiológiai Társaság X. Kongresszusa. 2011.08.31.2011.09.02. Szeged, Magyarország.

Csiszár J, Gallé Á, Horváth E, Dancsó P, Gombos M, Benyó D, Kolbert Zs, Secenji M, Györgyey J, Tari I, Erdei L (2010) Peroxidase activities and expression level during osmotic stress in roots of wheat genotypes differing in drought tolerance. ISIRR 2010 - 11th International Symposium "Interdisciplinary Regional Research": Hungary-Romania-Serbia. 2010.10.13-2010.10.15. Szeged, Magyarország. p. 24. (ISBN:978-963-508-600-9) 
Tari I, Csiszár J, Gallé Á, Guóth A, Horváth E, Poór P (2009) Az abszcizinsav szerepe vízpotenciált megtartó és vízpotenciál csökkenést toleráló búza genotípusok szárazságtürési stratégiájában. Miniszimpózium a Debreceni Egyetem Növénytani Tanszéke megalakulásának 80. évfordulójára, 2009.11.13-2009.11.14. Debrecen, Magyarország.

Tari I, Csiszár J, Gémes K, Horváth E, Szepesi Á, Poór P, Sulyok Z (2008) A szalicilsav, mint allelopatikus anyag. IX. Magyar Növénybiológiai Kongresszus. 2008.07.72008.07.09. Szeged, Magyarország.

\section{Konferencia poszterek}

Bela K, Horváth E, Kovács H, Csiszár J (2015) Importance of Arabidopsis thaliana glutathione peroxidases under drought and heat stresses. VISCEA, Plant Abiotic Stress Tolerance III. 2015.06.29-2015.07.01. Bécs, Ausztria. Programme and Abstracts p. 57.

Csiszár J, Horváth E, Bela, K, Brunner Sz, Lehotai N, Feigl G, Papdi Cs, Perez I, Kovács H, Szabados L, Ayaydin F, Tari I (2015) Redox homeostasis in salt treated Arabidopsis thaliana primed with salicylic acid. VISCEA, Plant Abiotic Stress Tolerance III. 2015.06.29-2015.07.01. Bécs, Ausztria. Programme and Abstracts p. 55.

Horváth E, Bela K, Csomor G, Brunner Sz, Papdi Cs, Szabados L, Csiszár J (2015) Modulation of salt stress responses in Arabidopsis thaliana glutathione transferase mutants. VISCEA, Plant Abiotic Stress Tolerance III. 2015.06.29-2015.07.01. Bécs, Ausztria. Programme and Abstracts p. 41.

Horváth E, Bela K, Brunner Sz, Papdi Cs, Szabados L, Csiszár J (2014) Salt stress responses of Arabidopsis glutathione transferase mutants. 11th Congress of the Hungarian Society of Plant Biology. 2014.09.27-2014.09.29. Szeged, Magyarország. Book of Abstracts p. 43 .

Bela K, Horváth E, Kovács H, Csiszár J (2014) Role of glutathione peroxidases in maintenance of redox homeostasis under drought and heat stresses in Arabidopsis thaliana. 11th Congress of the Hungarian Society of Plant Biology. 2014.09.27-2014.09.29. Szeged, Magyarország. Book of Abstracts p. 38.

Horváth E, Brunner Sz, Bela K, Csenki D, Papdi Cs, Szabados L, Tari I, Csiszár J (2013) The influence of salicylic acid pre-treatments on the salt stress response of Arabidopsis thaliana. Oxidative stress and cell death in plants: Mechanisms and implications. 2013.07.262013.07.28. Firenze, Olaszország. Programme and Abstract Book pp. 40-41. 
Csiszár J, Horváth E, Váry Zs, Gallé Á, Szepesi Á, Brunner Sz, Tari I (2012) Role of glutathione transferases in the hardening effect of salicylic acid in tomato. VIPCA II. Plant Abiotic Stress Tolerance II. 2012.02.22-2012.02.25. Wien, Ausztria. Paper 91.

Horváth E, Váry Zs, Brunner Sz, Gallé Á, Gémes K, Tari I, Csiszár J (2012) Hardening effect of salicylic acid - role of glutathione transferases in the improved stress tolerance. The 10th International Ph.D. Student Conference on Experimental Plant Biology. 2012.09.032012.09.05. Brno, Csehország. Book of Abstract p. 99.

Csiszár J, Gallé Á, Horváth E, Dancsó P, Pintér B, Gombos M, Váry Zs, Erdei L, Györgyey J, Tari I (2011) Differences in growth, $\mathrm{H}_{2} \mathrm{O}_{2}$ production, peroxidase activitiy and peroxidase transcript amounts during osmotic stress in roots of two wheat genotypes. 1st Congress of Cereal Biotechnology and Breeding. 2011.05.24-2011.05.27. Szeged, Magyarország. Book of Abstracts pp. 73-74.

Csiszár J, Váry Zs, Horváth E, Gallé Á, Szepesi Á, Gémes K, Poór P, Tari I (2011) Enhanced expression and activities of some GST isoenzymes during salt stress and their putative role in the elimination of reactive oxygen species in salicylic acid-primed tomato. 10th International Conference on Reactive Oxygen and Nitrogen Species in Plants. 2011.07.05-2011.07.08. Budapest, Magyarország. p. 156.

Csiszár J, Váry Zs, Horváth E, Gallé Á, Gémes K, Tari I (2011) Role of glutathione transferases in the hardening effect of salicylic acid in tomato. 2nd International Training Course Alumni Conference: Multidisciplinary Approaches to Biological Problems. 2011.11.01-2011.11.03. Szeged, Magyarország. p. 9.

Horváth E, Gallé Á, Dancsó P, Benyó D, Györgyey J, Tari I, Csiszár J (2011) $\mathrm{H}_{2} \mathrm{O}_{2}$ content, peroxidase activities and expression of stress-related peroxidases and their possible relationship under osmotic stress in two wheat genotypes differing in drought tolerance. 7th International Symposium: Structure and Function of Roots. 2011.09.05-2011.09.09. Nový Smokovec, Szlovákia. pp. 74-75.

Poór P, Horváth E, Gallé Á, Csiszár J, Tari I (2011) Salt stress- and salicylic acidinduced programmed cell death in tomato leaves. Experimental Plant Biology in 3P: Past, Present, Perspectives. 2011.09.06-2011.09.09. Wroclaw, Lengyelország. p. 75.

Csiszár J, Poór P, Gallé Á, Benyó D, Horváth E, Kolbert Zs, Erdei L, Tari I (2010) Role of $\mathrm{H}_{2} \mathrm{O}_{2}$, NO and peroxidases in the elongation growth of roots. Molecular Aspects of Plant Development Conference. 2010.02.23-2010.02.26. Wien, Ausztria. p. 45. 
Horváth E, Gallé Á, Váry Zs, Szepesi Á, Csiszár J, Tari I (2010) Abscisic aldehyde oxidase activity and gene expression levels in salicylic acid pre-treatment and subsequent $\mathrm{NaCl}$ stress. ISIRR 2010 - 11th International Symposium "Interdisciplinary Regional Research": Hungary-Romania-Serbia. 2010.10.13-2010.10.15. Szeged, Magyarország. p. 93. (ISBN: 978-963-508-600-9)

\section{Egyéb közlemények}

Bela K, Horváth E, Kovács H, Brunner Sz, Csiszár J (2014) Investigation of the role of Arabidopsis thaliana glutathione peroxidases in drought, chilling and heat stress responses using insertion mutants. Tavaszi Szél 2014/Spring Wind 2014 Konferenciakötet V.. Konferencia helye, ideje: Debrecen, Magyarország, 2014.03.21-2014.03.23. (Doktoranduszok Országos Szövetsége, Biológiai és Kémiai Tudományok Osztálya) pp. 582-590. (ISBN:978-963-89560-9-5)

Bela K, Mainé Csiszár J, Horváth E, Brunner Sz, Zsigmond L (2013) Glutation peroxidázok ozmotikus stresszválaszban betöltött szerepének tanulmányozása Arabidopsis thaliana inszerciós mutánsokkal. Tavaszi Szél, 2013: Spring wind, 2013. 659 p. Sopron, Magyarország, 2013.05.31-2013.06.02. Budapest: Doktoranduszok Országos Szövetsége, 2013. pp. 350-356. 1-2. kötet (ISBN: 978-963-89560-2-6)

Horváth E, Kolbert Zs, Lehotai N, Feigl G, Tari I, Erdei L (2013) Role of reactive oxygen and nitrogen species in poplar plants during abiotic stress. HUSRB/1002/214/036 "OXIT" Characterization and oxidative stress tolerance in plants. 2013.11.14 Novi Sad, Szerbia. Book of final report pp. 63-70.

Gallé Á, Csiszár J, Kolbert Zs, Szepesi Á, Benyó D, Krastinyté V, Kisielyté N, Durbecq A, Horváth E, Szabó-Hevér Á, Mesterházy Á, Tari I, Erdei L (2012) Investigation of oxidative stress responses in wheat flag leaves after inoculation with Fusarium species. HURO/0901/147/2.2.2 Szeged - Timisoara Axis for the Safe Food and Feed SZETISA1. 2012.05.15-2012.05.16. Szeged, Magyarország. Book of Final Report. pp. 78-91.

Szepesi Á, Gallé Á, Csiszár J, Brunner Sz, Benyó D, Feigl G, Horváth E, Szabó-Hevér Á, Mesterházy Á, Tari I, Erdei L (2012) Non-enzymatic antioxidant responses of wheat flag leaves after Fusarium culmorum and F. graminearum infections. HURO/0901/147/2.2.2

Szeged - Timisoara Axis for the Safe Food and Feed SZETISA1. 2012.05.15-2012.05.16. Szeged, Magyarország. Book of Final Report pp. 74-77. 


\section{Díjak és elismerések}

XXIX. Országos Tudományos Diákköri Konferencia, 2009. - II. díj

Sófi József a Szegedi Tehetségekért Alapítvány, Biológia Doktori Iskola kategóriában kihírdetett pályázat - II. helyezés

Nemzeti Kiválóság Program - Hazai hallgatói, illetve kutatói személyi támogatást biztosító

rendszer kidolgozása és müködtetése országos és konvergencia program Ösztöndíj, 20132014. 


\section{Köszönetnyilvánítás}

Köszönöm témavezetőm Dr. Csiszár Jolánnak, hogy csatlakozhattam a munkacsoporthoz és szeretném megköszönni az évek során nyújtott segítséget, a tanácsait és a bizalmat, hogy mindig támogatott és mellettem állt szakmai és emberi vonatkozásban egyaránt! Köszönöm, hogy lehetővé tette a munkám befejezését a Növénybiológiai Tanszéken!

Köszönettel tartatozom Dr. Tari Irma Tanárnönek volt szakvezetőmnek, hogy elindított a növényélettani kutatások útján és irányt mutatott a munkám folytatásához a későbbiekben, pedig mint tanszékvezető lehetővé tette a munkám elvégzését a Növénybiológiai Tanszéken!

Köszönöm volt tanszékvezetőnknek, Dr. Erdei László Tanár Úrnak, hogy lehetővé tette a munkám megkezdését a Növénybiológiai Tanszéken és köszönöm az évek során nyújtott támogatását!

Szeretném megköszönni Dr. Gallé Ágnesnek, hogy bevezetett a kvantitatív RT-PCR és a molekuláris munka rejtelmeibe és köszönet a támogatásért és kedvességért, amit az évek során kaptam!

Köszönöm munkacsoportunk jelenlegi és volt tagjainak, Bela Krisztinek, Benyó Daninak és Brunner Szilvinek a segítséget, amit a munkám elvégzéséhez nyújtottak! Daninak külön köszönöm a növényekről készített csodás képeket, Krisztinek pedig, hogy bármikor készen állt segíteni!

Köszönöm a $P h D$ szoba valamennyi volt és jelenlegi lakójának a segítséget és a jókedvet, ami végigkísért az évek során!

Köszönettel tartozom Dr. Ördög Attilának az ICP mérések elvégzéséért!

Köszönöm valamennyi szakdolgozónknak és a Növénybiológiai Tanszék minden munkatársának az elmúlt évek során a munkához nyújtott felbecsülhetetlen segítséget, és a jó hangulatban telt napokat!

Köszönöm az SzBK, Arabidopsis Molekuláris Genetikai Csoport valamennyi volt és jelenlegi munkatársának a munkám elvégzéséhez nyújtott segítséget, és hogy rendelkezésünkre bocsátották a kísérletekhez használt Arabidopsis mutáns magokat.

Tiszta szívből köszönöm családomnak az évek során nyújtott támogatásukat, gondoskodásukat és kitartásukat! Köszönöm, hogy mindig mellettem álltatok, bíztatok bennem és erőt adtatok a munkám elvégzéséhez! 


\section{Mellékletek}

1. melléklet: Hét hetes kontroll (0 M SA) és $10^{-4} \mathrm{M} \mathrm{SA}$ kezelt növények két héttel a SA előkezelés megkezdése után.
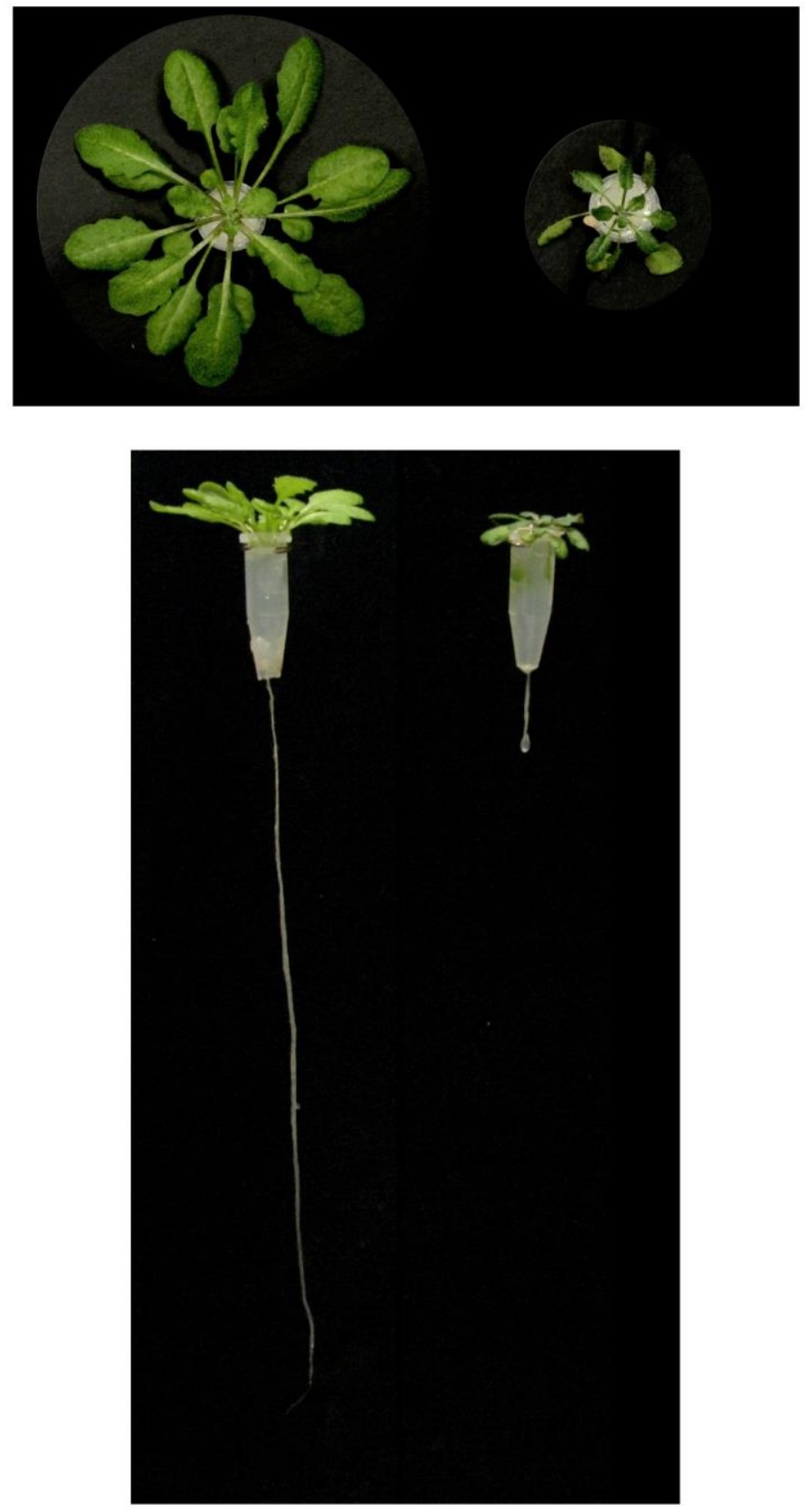
2. melléklet: Lúdfü növényeken végzet QRT-PCR vizsgálatokban alkalmazott primer párok.

\begin{tabular}{|c|c|c|c|c|}
\hline A lúdfü gén neve & $\begin{array}{l}\text { A dolgozatban } \\
\text { használt rövidítés }\end{array}$ & $\begin{array}{l}\text { Lúdfú genomban } \\
\text { található lókusz } \\
\text { azonosítója }\end{array}$ & & Primer pár szekvenciája (5'-3') \\
\hline $\begin{array}{l}\text { Glutation transzferáz } \\
\text { phi } 8\end{array}$ & $\overline{A t G S T F 8}$ & At2g47730 & $\begin{array}{l}\text { F: } \\
\text { R: }\end{array}$ & $\begin{array}{l}\text { ACGGTGATTTGACGCTTTTC } \\
\text { GGTTGCCTTGACTTTCTTGC }\end{array}$ \\
\hline $\begin{array}{l}\text { Glutation transzferáz } \\
\text { phi } 9\end{array}$ & AtGSTF9 & At2g30860 & $\begin{array}{l}\mathrm{F}: \\
\mathrm{R}:\end{array}$ & $\begin{array}{l}\text { GGGAAAACCGTTGAAGACAG } \\
\text { ATGACTGATGCGAACATTATG }\end{array}$ \\
\hline $\begin{array}{l}\text { Glutation transzferáz } \\
\text { tau } 19\end{array}$ & AtGSTU19 & At $\lg 78380$ & $\begin{array}{l}\mathrm{F}: \\
\mathrm{R}:\end{array}$ & $\begin{array}{l}\text { ATGATGCTCAGAGGAAGGTG } \\
\text { ATAGCCAAAGTCATCGCCAC }\end{array}$ \\
\hline $\begin{array}{l}\text { Glutation transzferáz } \\
\text { tau } 24\end{array}$ & AtGSTU24 & Atlg17170 & $\begin{array}{l}\text { F: } \\
\text { R: }\end{array}$ & $\begin{array}{l}\text { AAGGTGAGGAGCAAGAAGCA } \\
\text { ACATACCCAAAAGTTTCGTCTC }\end{array}$ \\
\hline $\begin{array}{l}\text { Glutation transzferáz } \\
\text { tau } 25\end{array}$ & AtGSTU25 & At $\lg 17180$ & $\begin{array}{l}\mathrm{F}: \\
\mathrm{R}:\end{array}$ & $\begin{array}{l}\text { AGCAAAACCCCACTTCTTCC } \\
\text { CTCCCCAAATCAACCTCGC }\end{array}$ \\
\hline $\begin{array}{l}\text { 18S riboszómális } \\
\text { RNS }\end{array}$ & $18 S$ rRNS & $\begin{array}{l}\text { At3g41768 } \\
\text { At2g01010 }\end{array}$ & $\begin{array}{l}\text { F: } \\
\text { R: }\end{array}$ & $\begin{array}{l}\text { ATACGTGCAACAAACCC } \\
\text { CTACCTCCCCGTGTCA }\end{array}$ \\
\hline Aktin $2 / 8$ gén & aktin2 & At3g 18780 & $\begin{array}{l}\mathrm{F}: \\
\mathrm{R}:\end{array}$ & $\begin{array}{l}\text { GGTAACATTGTGCTCAGTGGTGG } \\
\text { AACGACCTTAATCTTCATGCTGC }\end{array}$ \\
\hline
\end{tabular}


3. melléklet: Paradicsom növényeken végzet QRT-PCR vizsgálatokban alkalmazott primer párok.

\begin{tabular}{|c|c|c|c|c|}
\hline A gén neve & $\begin{array}{l}\text { A dolgozatban } \\
\text { használt } \\
\text { rövidítés }\end{array}$ & $\begin{array}{l}\text { Paradicsom } \\
\text { genomban } \\
\text { található lókusz } \\
\text { azonosítója }\end{array}$ & & Primer pár szekvenciája (5'-3') \\
\hline Zeaxantin epoxidáz & SIZEP & Solyc02g090890 & $\begin{array}{l}\mathrm{F}: \\
\mathrm{R}:\end{array}$ & $\begin{array}{l}\text { GAAGAGGTCGTGTTACATTGC } \\
\text { TGCTTTTTCAAGTTCCAGTGC }\end{array}$ \\
\hline $\begin{array}{l}\text { 9-cisz-epoxikarotinoid } \\
\text { dioxigenáz } 1\end{array}$ & SINCED1 & Solyc07g056570 & $\begin{array}{l}\mathrm{F}: \\
\mathrm{R}:\end{array}$ & $\begin{array}{l}\text { ACATAATAGGCAAAGTCTCA } \\
\text { GTTGAAGAAGAAGAGGAGTT }\end{array}$ \\
\hline $\begin{array}{l}\text { Karotinoid hasító } \\
\text { dioxigenáz 1B }\end{array}$ & SlCCD 1B & Solyc01g087260 & $\begin{array}{l}\mathrm{F}: \\
\mathrm{R}:\end{array}$ & $\begin{array}{l}\text { CCGATGAAACTCCTCCACTT } \\
\text { GCCATCTCCATCAAACCAAT }\end{array}$ \\
\hline $\begin{array}{l}\text { Karotinoid hasító } \\
\text { dioxigenáz 1A }\end{array}$ & SICCD 1A & Solyc01g087250 & $\begin{array}{l}\mathrm{F}: \\
\mathrm{R}:\end{array}$ & $\begin{array}{l}\text { GGGAGGAGGGAGATGAAGTC } \\
\text { TCTAGGTCTGGGTTCACAAGG }\end{array}$ \\
\hline Aldehid oxidáz 1 & SlAO1 & Solyc11g071620 & $\begin{array}{l}\mathrm{F}: \\
\mathrm{R}:\end{array}$ & $\begin{array}{l}\text { CCAGGCACAAACACAATCAA } \\
\text { GTCGTAAATAATATCAGACTG }\end{array}$ \\
\hline Aldehid oxidáz 2 & $\mathrm{SlAO} 2$ & Solyc01g088170 & $\begin{array}{l}\mathrm{F}: \\
\mathrm{R}:\end{array}$ & $\begin{array}{l}\text { TTCCAGACGAAGACAACTGC } \\
\text { GACAAGTGGCAATCACACGA }\end{array}$ \\
\hline Aldehid oxidáz 3 & SlAO3 & Solyc11g071600 & $\begin{array}{l}\mathrm{F}: \\
\mathrm{R}:\end{array}$ & $\begin{array}{l}\text { AGTTGGCAGTGTCCTCAAGC } \\
\text { GACTTCATACACGATTGGCACT }\end{array}$ \\
\hline $\begin{array}{l}\text { Glutation transzferáz } \\
\text { tau } 6\end{array}$ & SIGSTU6 & Solyc01g099590 & $\begin{array}{l}\mathrm{F}: \\
\mathrm{R}:\end{array}$ & $\begin{array}{l}\text { CTCGTTTTGTTGATGGCAAG } \\
\text { TCCCTCTGCTTTTGTTTCTCC }\end{array}$ \\
\hline $\begin{array}{l}\text { Glutation transzferáz } \\
\text { tau } 23\end{array}$ & SIGSTU23 & Solyc07g056470 & $\begin{array}{l}\mathrm{F}: \\
\mathrm{R}:\end{array}$ & $\begin{array}{l}\text { GGTGATTTTGTTGGATTTTTGG } \\
\text { AGCAGAGGGCTTTTGTTCG }\end{array}$ \\
\hline $\begin{array}{l}\text { Glutation transzferáz } \\
\text { tau } 24\end{array}$ & $\begin{array}{l}\text { SlGSTU24 } \\
\text { (BI-GST) }\end{array}$ & Solyc07g056480 & $\begin{array}{l}\mathrm{F}: \\
\mathrm{R}:\end{array}$ & $\begin{array}{l}\text { TTGCGAGTCTATTATTGGAGTTGA } \\
\text { GGATCAGAAGGGAGGAAAGG }\end{array}$ \\
\hline $\begin{array}{l}\text { Glutation transzferáz } \\
\text { tau } 26\end{array}$ & SIGSTU26 & Solyc07g056500 & $\begin{array}{l}\mathrm{F}: \\
\mathrm{R}:\end{array}$ & $\begin{array}{l}\text { TGCTAGGTTTTGGGCTGATT } \\
\text { TTGGCTGTTTTGTGCTCTTC }\end{array}$ \\
\hline $\begin{array}{l}\text { Glutation transzferáz } \\
\text { phi } 4\end{array}$ & SlGSTF4 & Solyc09g074850 & $\begin{array}{l}\mathrm{F}: \\
\mathrm{R}:\end{array}$ & $\begin{array}{l}\text { CGTGTGAGTGTATGGTGTGCT } \\
\text { CATCTTCTCCAACCCCTTCA }\end{array}$ \\
\hline $\begin{array}{l}\text { Glutation transzferáz } \\
\text { phi } 5\end{array}$ & SlGSTF5 & Solyc12g094430 & $\begin{array}{l}\mathrm{F}: \\
\mathrm{R}:\end{array}$ & $\begin{array}{l}\text { CCGATCTCTCTCACCTTCCA } \\
\text { TGCTCTGTCTGTCCCGTTC }\end{array}$ \\
\hline $\begin{array}{l}\text { Glutation transzferáz } \\
\text { zéta } 2\end{array}$ & SlGSTZ2 & Solyc01g102660 & $\begin{array}{l}\mathrm{F}: \\
\mathrm{R}:\end{array}$ & $\begin{array}{l}\text { CACATTGGTGGATGGAGATG } \\
\text { ATGCTCGCTGGGGATACTT }\end{array}$ \\
\hline $\begin{array}{l}\text { Glutation transzferáz } \\
\text { théta } 2\end{array}$ & SlGSTT2 & Solyc08g080900 & $\begin{array}{l}\mathrm{F}: \\
\mathrm{R}:\end{array}$ & $\begin{array}{l}\text { GGTGAGTTCGTCGGAGTTAATTT } \\
\text { CGAGAAGGTTGGGACATACG }\end{array}$ \\
\hline $\begin{array}{l}\text { Dehidroaszkorbát } \\
\text { reduktáz } 2\end{array}$ & SIDHAR2 & Solyc05g054760 & $\begin{array}{l}\mathrm{F}: \\
\mathrm{R}:\end{array}$ & $\begin{array}{l}\text { TTCCTACCTTCGTCTCATTTCTG } \\
\text { AACAAACATTCTGCCCATTGA }\end{array}$ \\
\hline $\begin{array}{l}\text { Dehidroaszkorbát } \\
\text { reduktáz } 5\end{array}$ & SIDHAR5 & Solyc11g011250 & $\begin{array}{l}\mathrm{F}: \\
\mathrm{R}:\end{array}$ & $\begin{array}{l}\text { GGTGCCAGATTCAGATGTCA } \\
\text { CGGAGTCTTTGCTTTTCAGG }\end{array}$ \\
\hline $\begin{array}{l}\text { Glutation transzferáz } \\
\text { lambda } 3\end{array}$ & SlGSTL3 & Solyc $10 \mathrm{~g} 084400$ & $\begin{array}{l}\mathrm{F}: \\
\mathrm{R}:\end{array}$ & $\begin{array}{l}\text { GTGCCCTCTCTGGAACACA } \\
\text { AACGGACCCTCAAAGTTGC }\end{array}$ \\
\hline $\begin{array}{l}\text { Elongációs factor } 1 \alpha \\
\text { alegysége }\end{array}$ & $\mathrm{EF} 1 \alpha$ & Solyc06g005060 & $\begin{array}{l}\mathrm{F}: \\
\mathrm{R}:\end{array}$ & $\begin{array}{l}\text { GGAACTTGAGAAGGAGCCTAAG } \\
\text { CAACACCAACAGCAACAGTCT }\end{array}$ \\
\hline $\begin{array}{l}\text { Glicerinaldehid-3- } \\
\text { foszfát dehidrogenáz }\end{array}$ & GAPDH & Solyc $05 \mathrm{~g} 014470$ & $\begin{array}{l}\mathrm{F}: \\
\mathrm{R}:\end{array}$ & $\begin{array}{l}\text { ACAACTTAACGGCAAATTGACTGG } \\
\text { TTACCCTCTGATTCCTCCTTGATTG }\end{array}$ \\
\hline
\end{tabular}


4. melléklet: A vizsgált lúdfü GST gének 5' szabályozó régiójában található nukleotid motívumok és a hozzájuk tartozó leírások. A CAAT doboz és TATA doboz motívumokat nem tartalmazza a táblázat, mivel minden vizsgált AtGST gén promóter régiójában megtalálhatóak voltak.

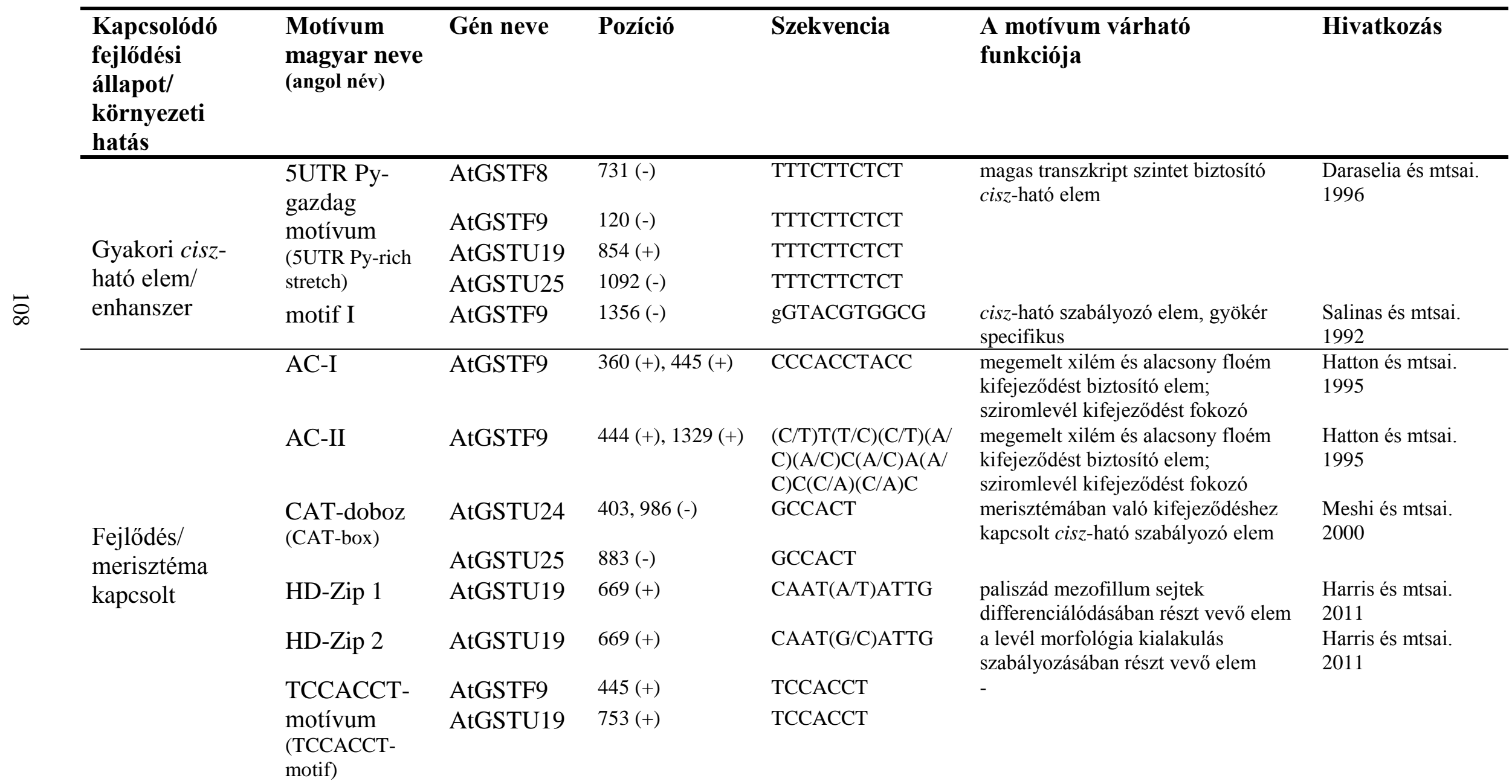




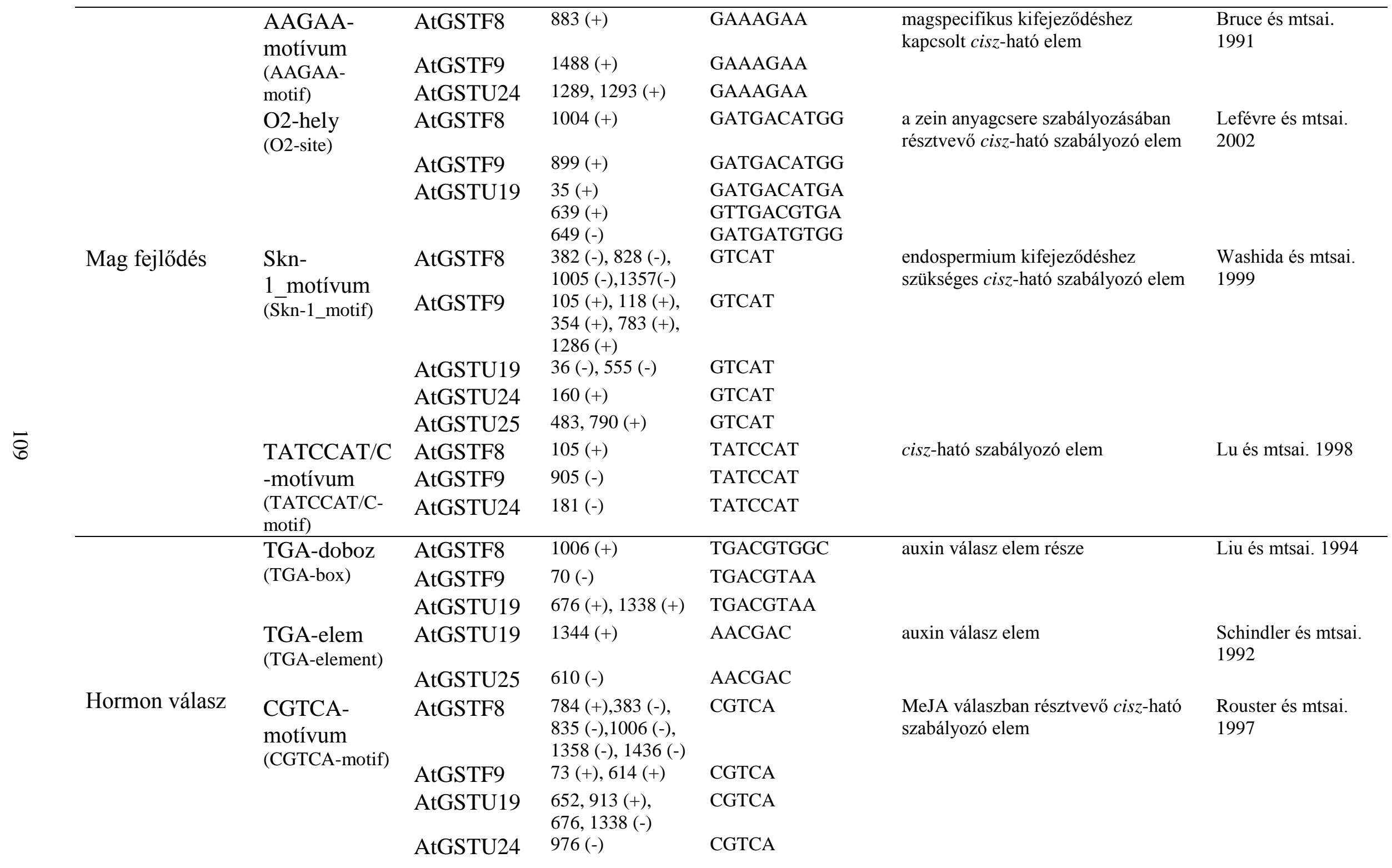




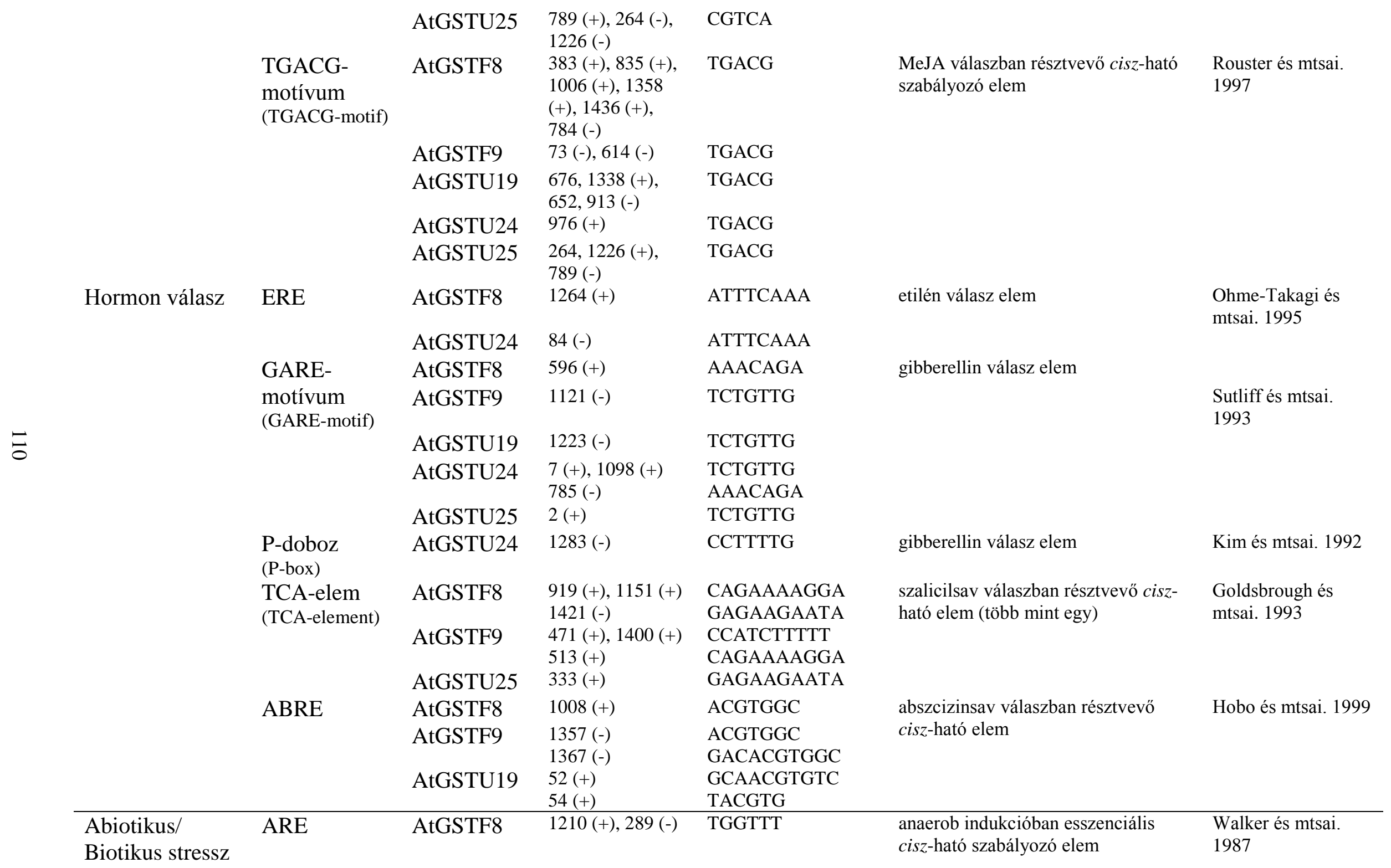




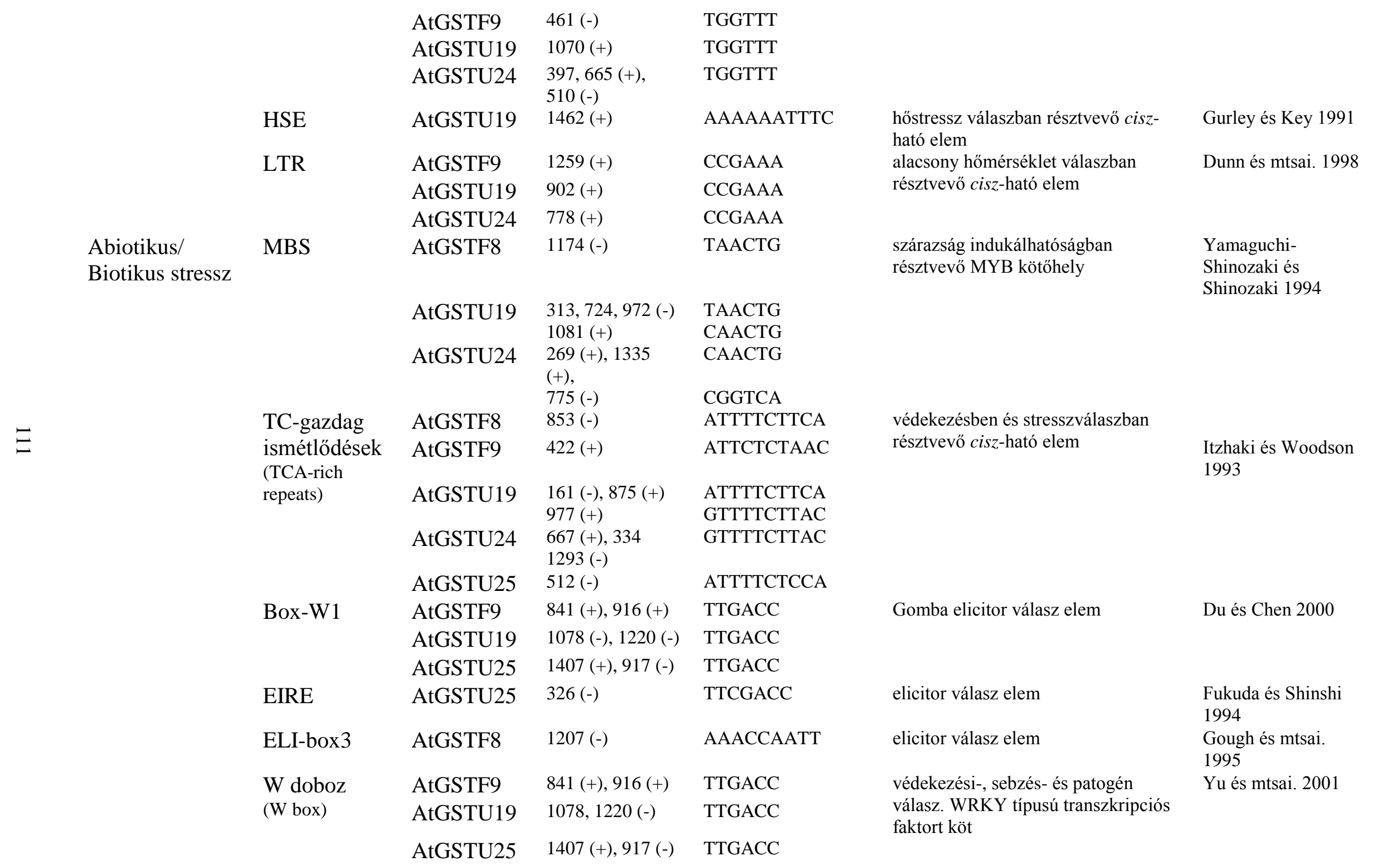




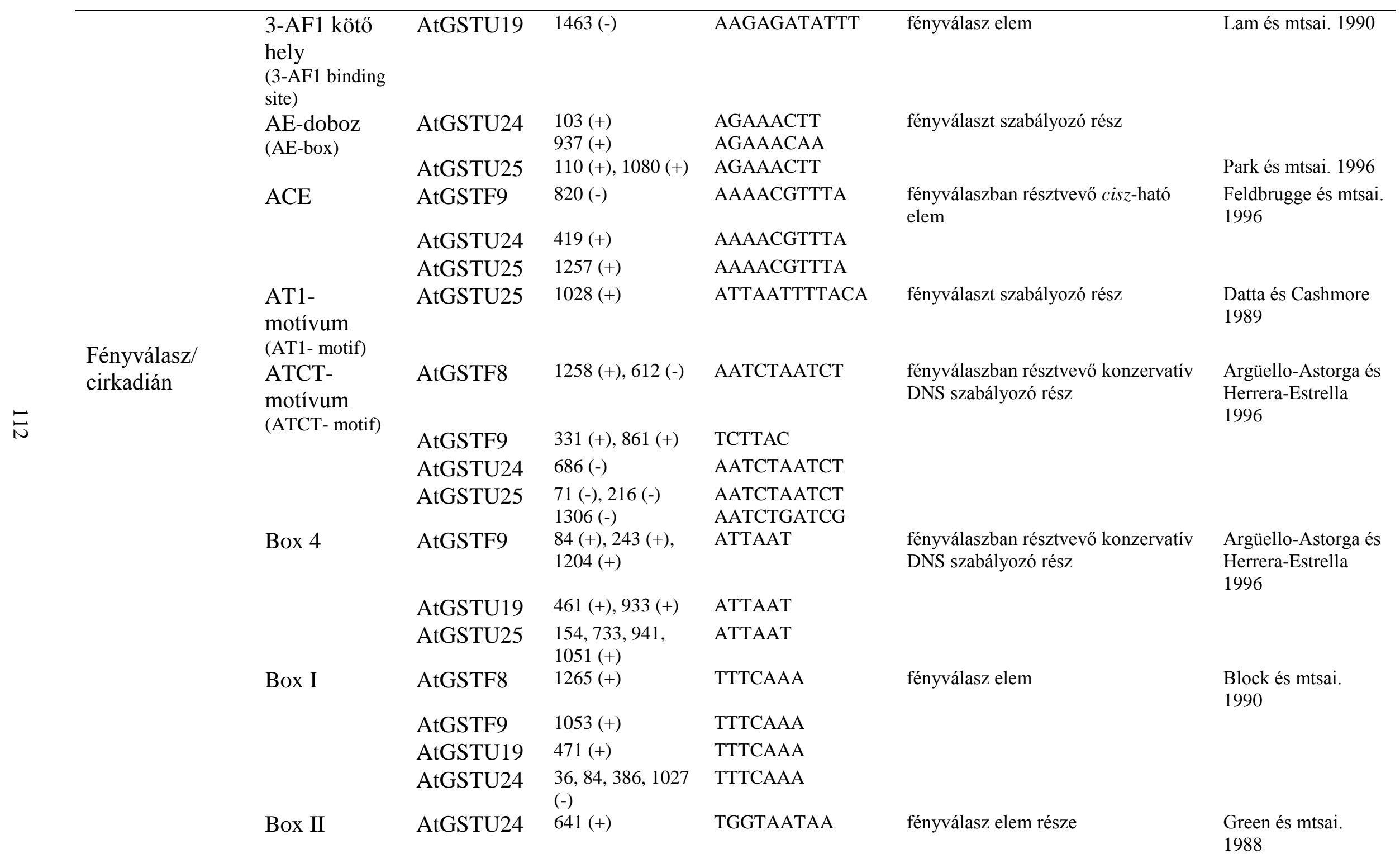




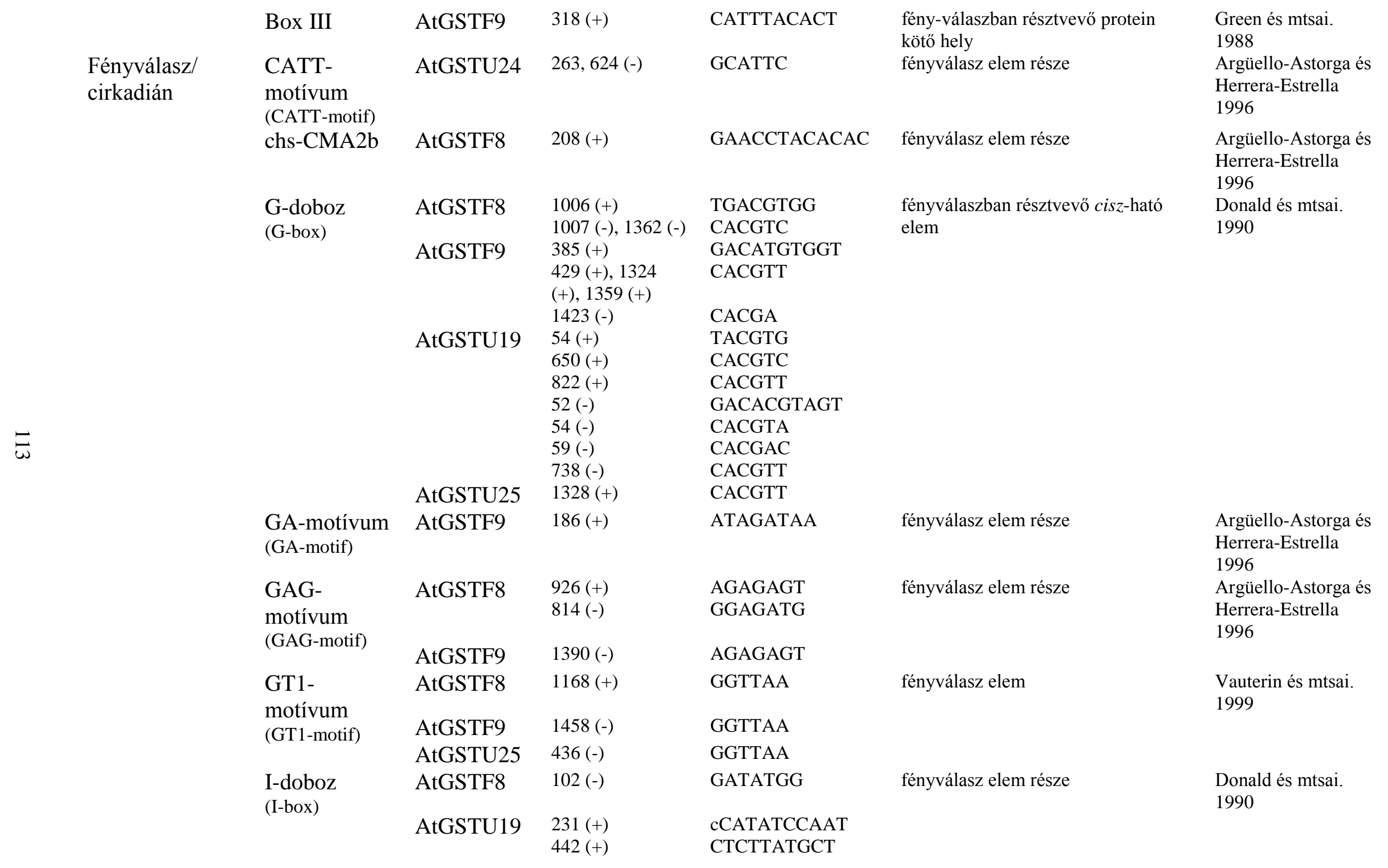




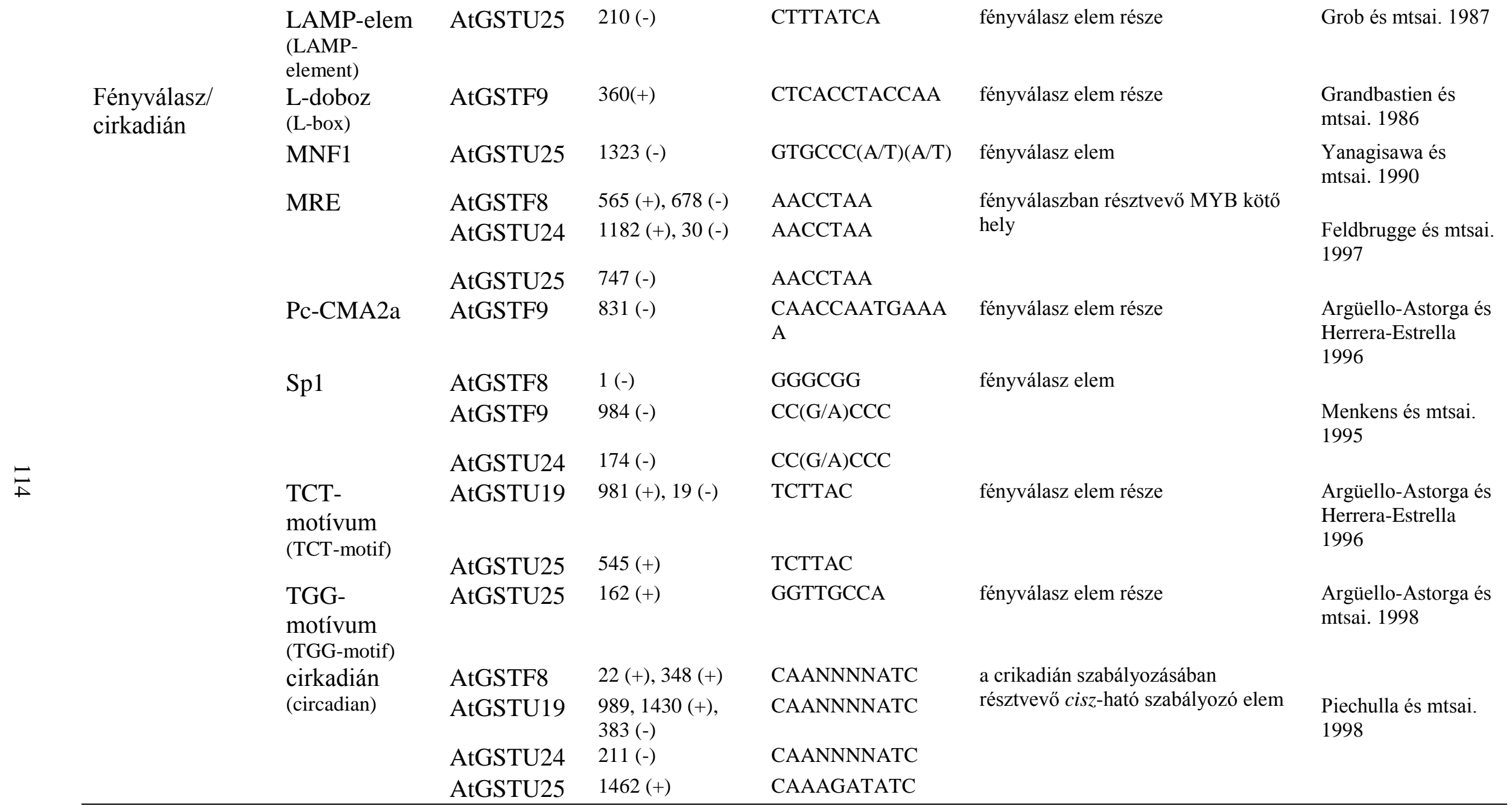


5. melléklet: A vizsgált paradicsom GST gének 5' szabályozó régiójában található nukleotid motívumok és a hozzájuk tartozó leírások. A CAAT doboz és TATA doboz motívumokat nem tartalmazza a táblázat, mivel minden vizsgált SlGST gén promóter régiójában megtalálhatóak voltak.

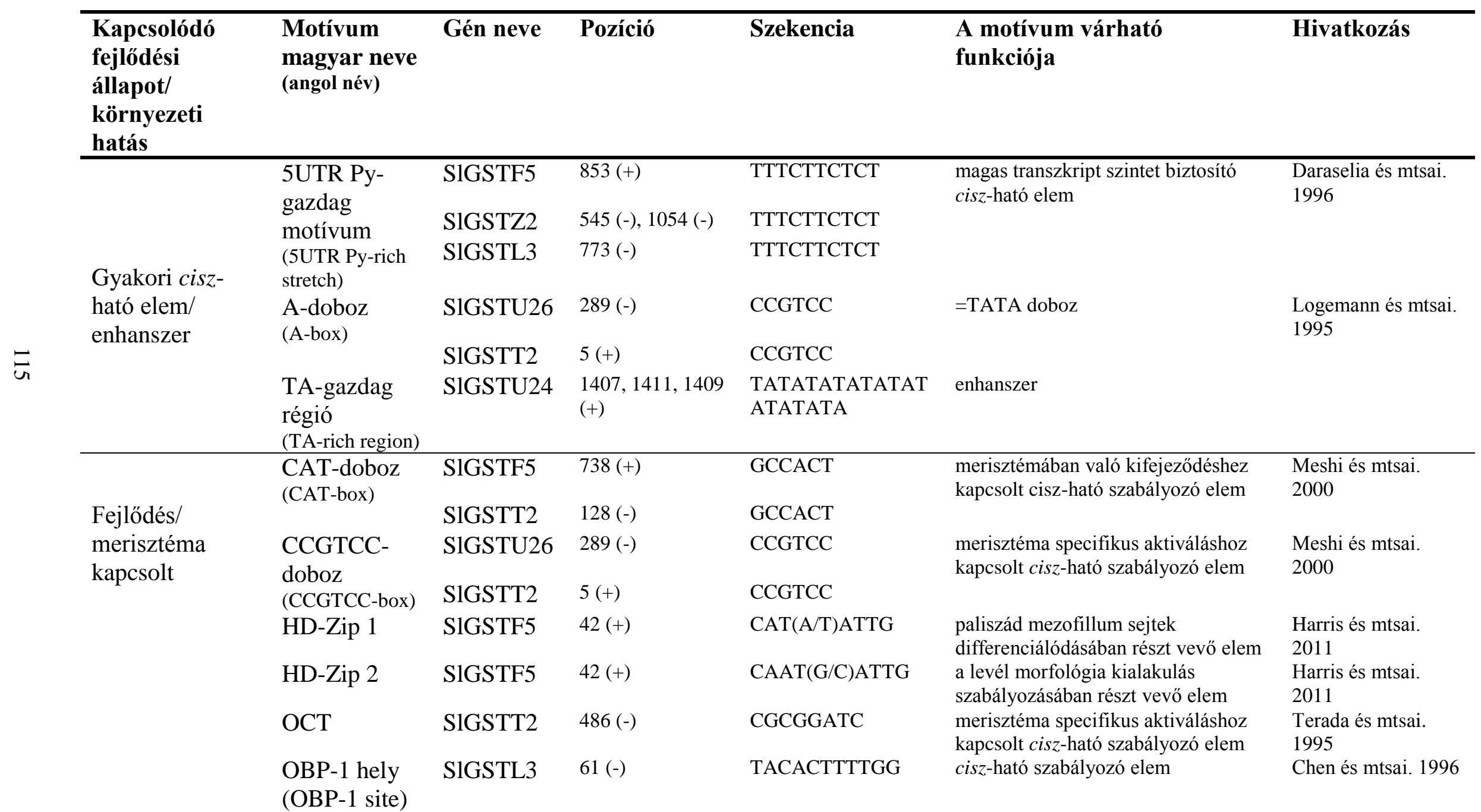




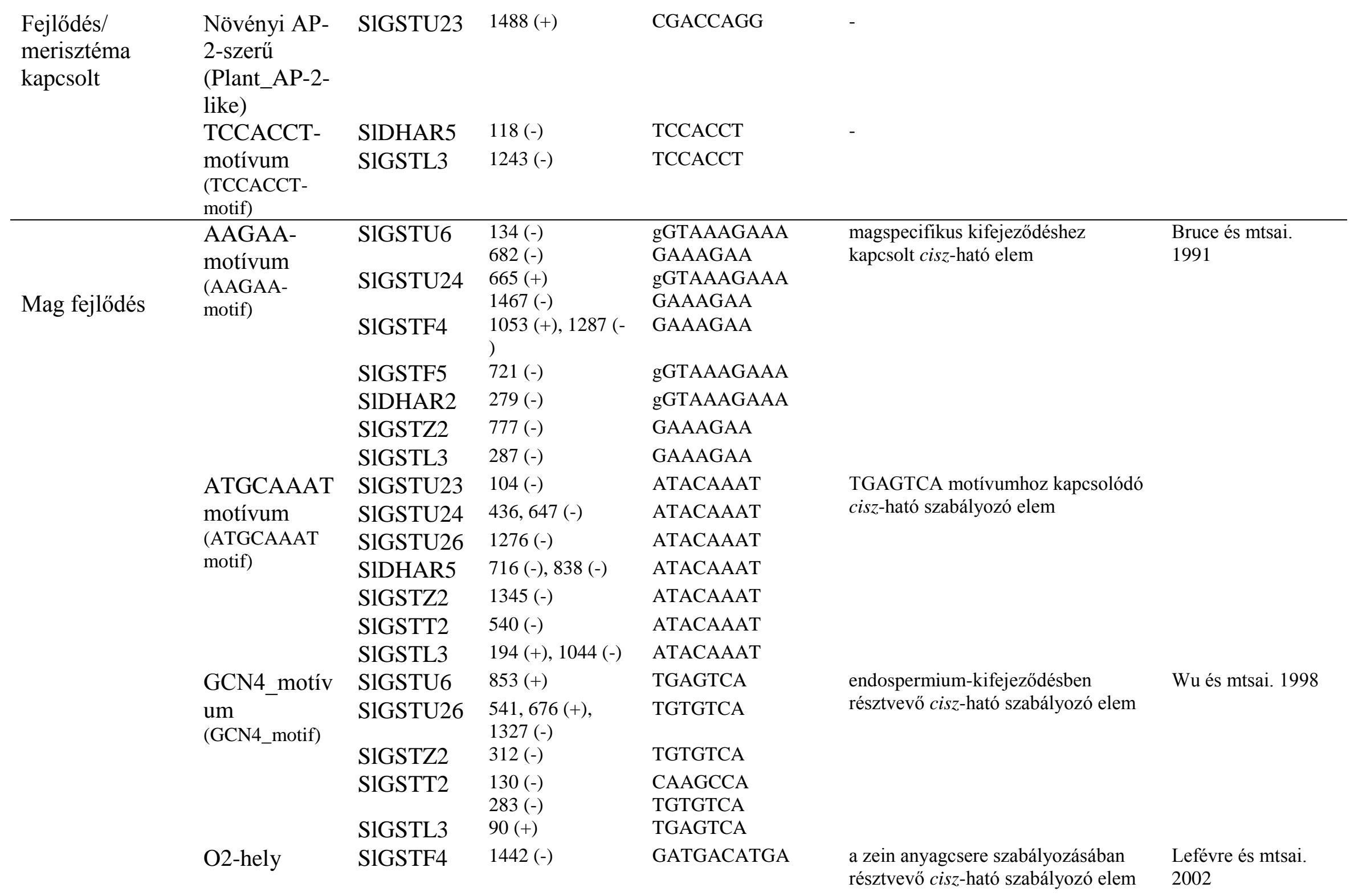




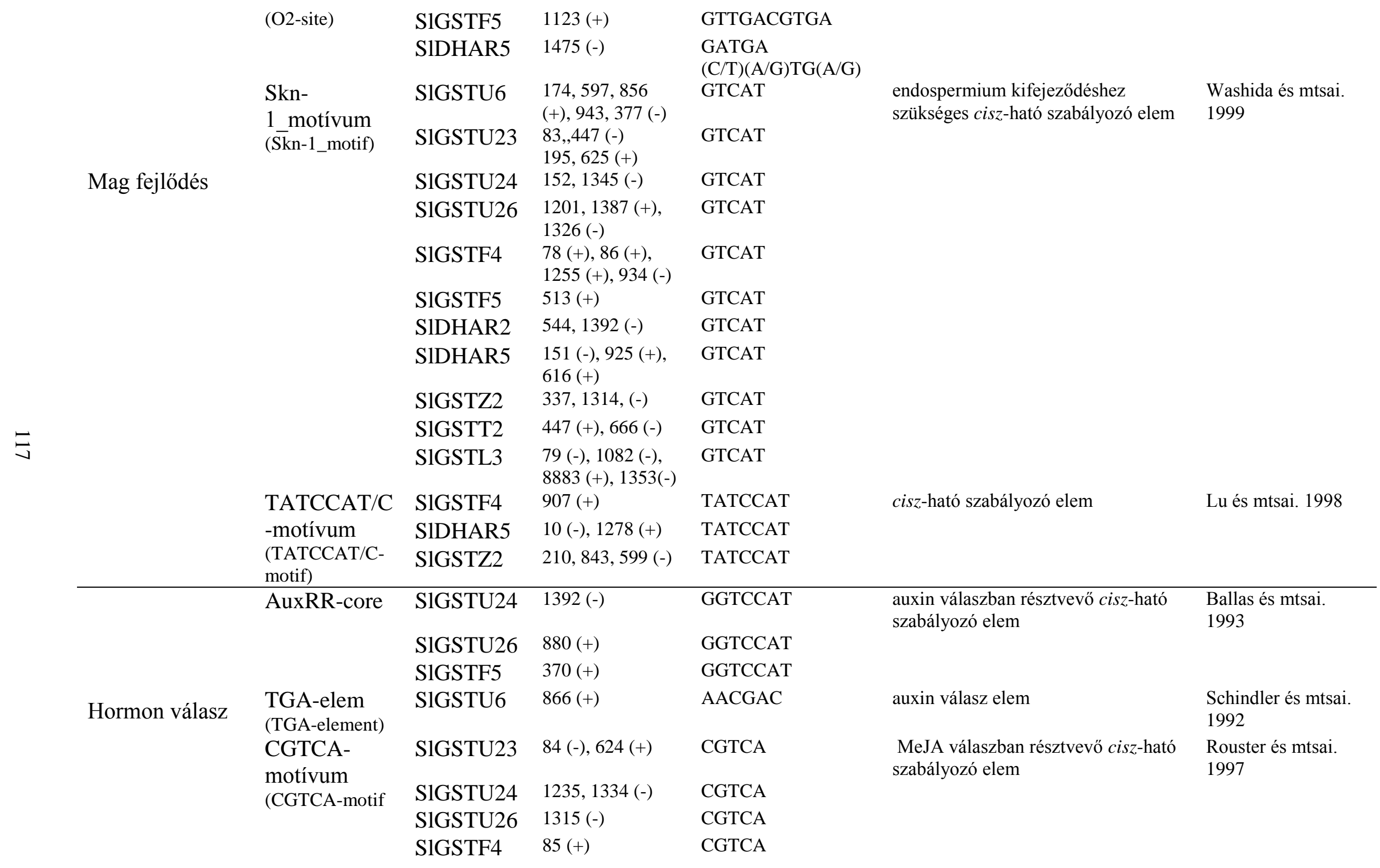




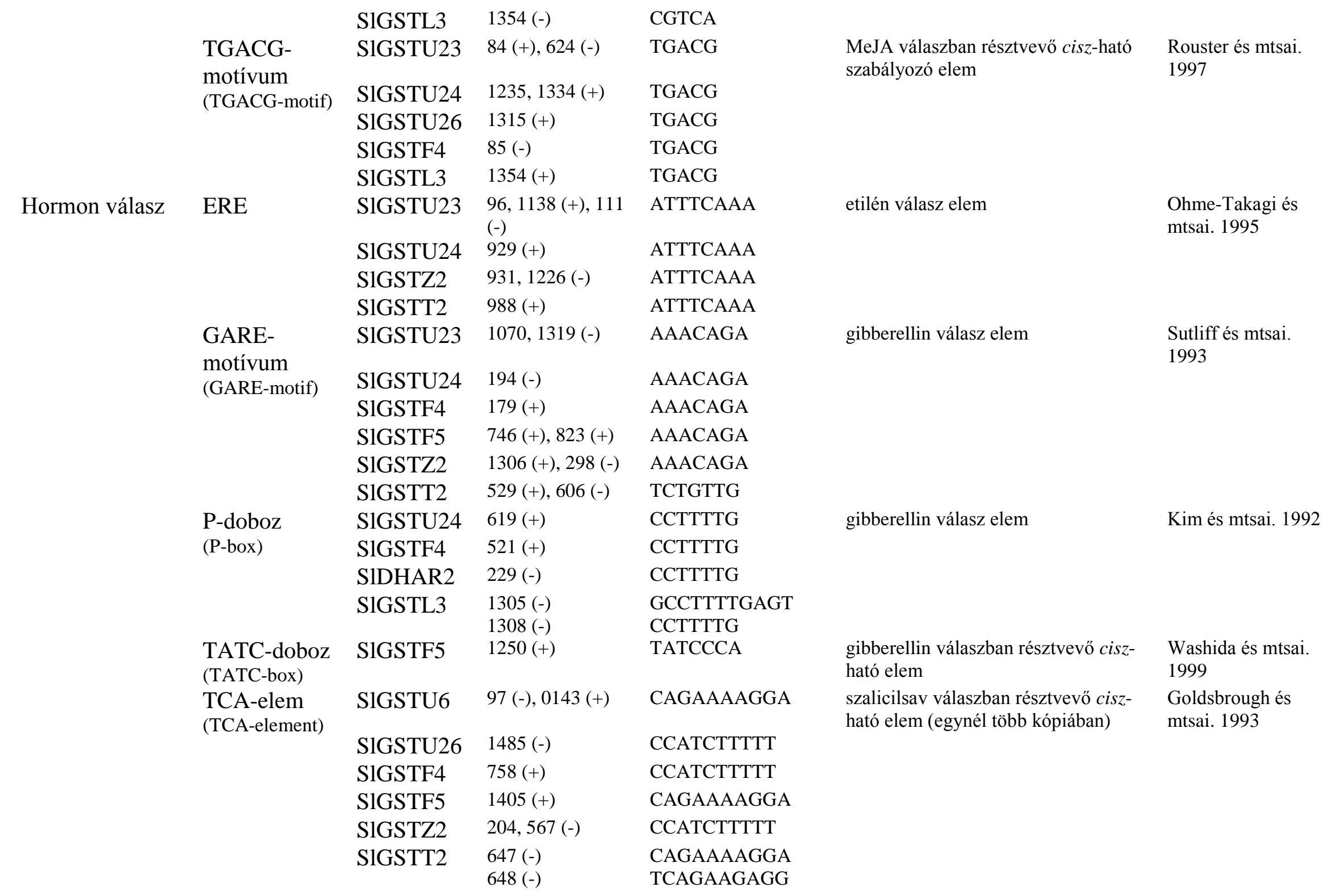




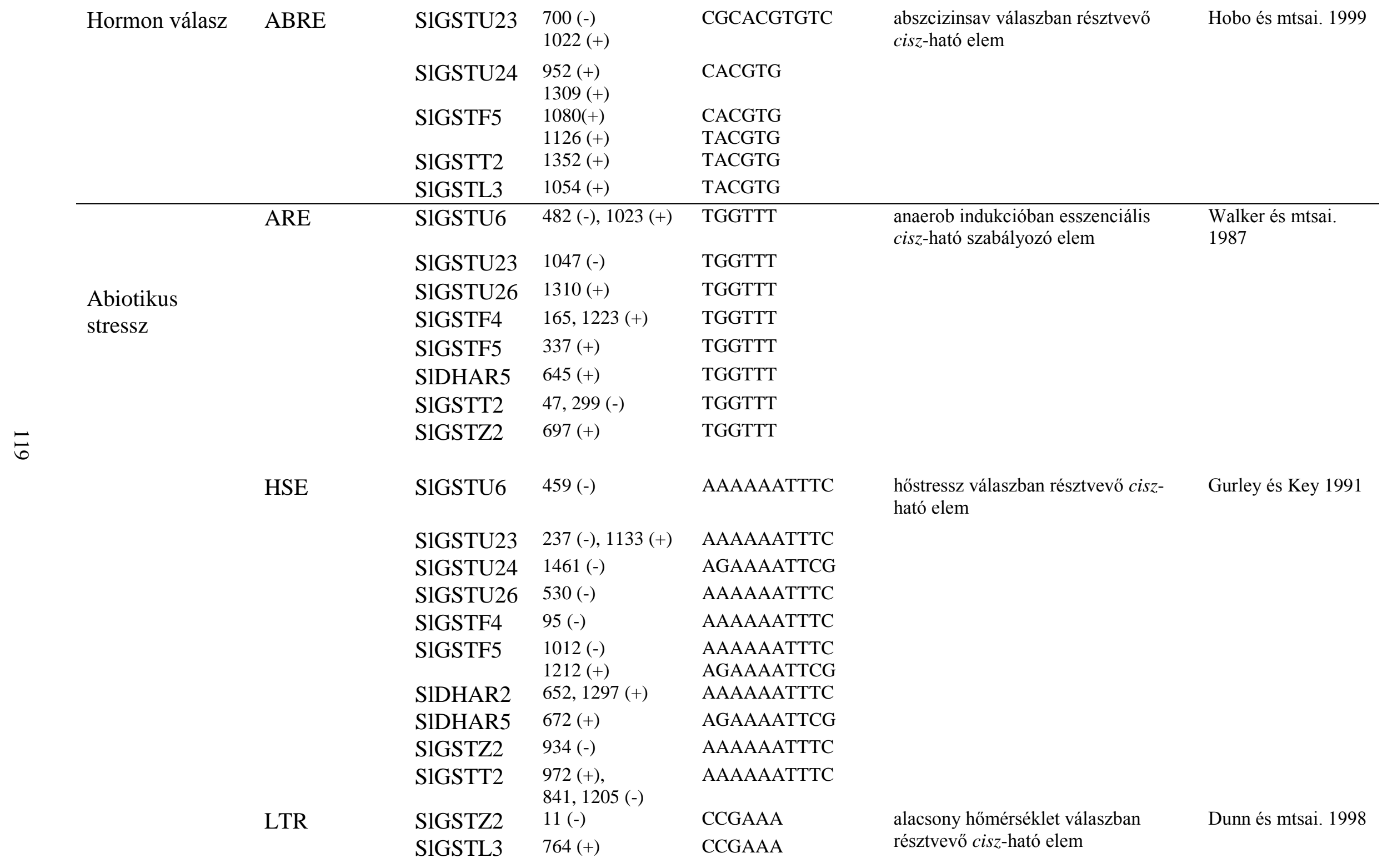




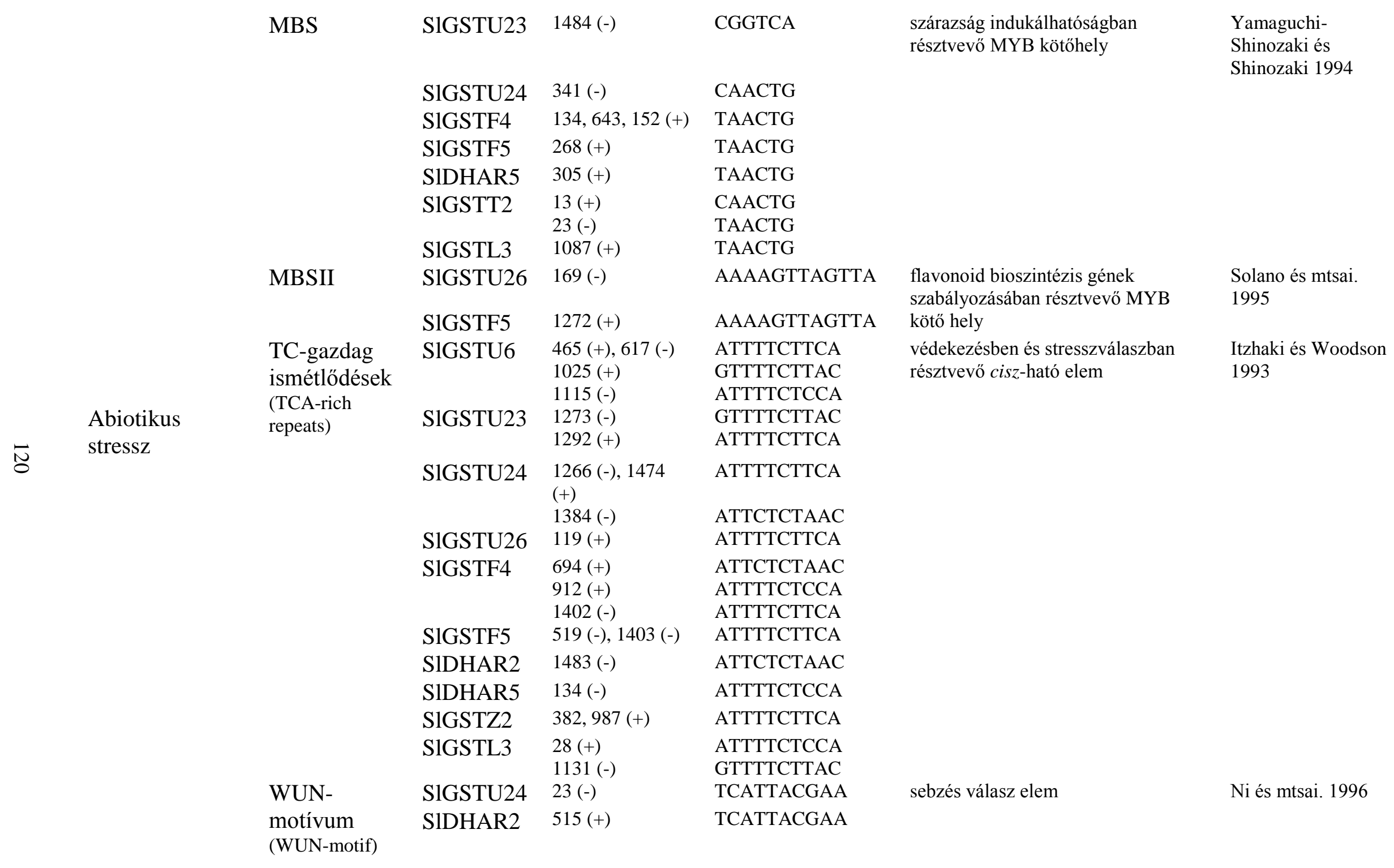




\begin{tabular}{|c|c|c|c|c|c|c|}
\hline \multirow{6}{*}{ Biotikus stressz } & Box $\mathrm{S}$ & SlGSTU23 & $1014(-)$ & AGCCACC & elicitor, sebzés és patogén válasz & Kirsch és mtsai. \\
\hline & $\begin{array}{l}\text { AT-gazdag } \\
\text { szekvencia } \\
\text { (AT-rich } \\
\text { sequence) }\end{array}$ & SIDHAR2 & $1180(+)$ & TAAAATACT & $\begin{array}{l}\text { maximális elicitor aktiválást } \\
\text { szabályozó elem ( } 2 \text { kópia) }\end{array}$ & $\begin{array}{l}\text { Lundin és mtsai. } \\
1994\end{array}$ \\
\hline & Box $E$ & SIGSTU24 & $426(+)$ & ACCCATCAAG & \multirow{2}{*}{$\begin{array}{l}\text { gomba elicitor általi indukcióhoz } \\
\text { kapcsolódó cisz-ható elem } \\
\text { gomba elicitor válasz elem }\end{array}$} & \multirow{2}{*}{$\begin{array}{l}\text { Zahur és mtsai. } \\
2009 \\
\text { Du és Chen } 2000\end{array}$} \\
\hline & Box-W1 & SIGSTU23 & $1483(+)$ & TTGACC & & \\
\hline & ELI-box3 & SlGSTF4 & $1220(-)$ & AAACCAATT & elicitor válasz elem & \multirow{2}{*}{$\begin{array}{l}\text { Fukuda és Shinshi } \\
1994 \\
\text { Gough és mtsai. } \\
1995 \\
\text { Yu és mtsai. } 2001\end{array}$} \\
\hline & $\begin{array}{l}\text { W doboz } \\
\text { (W box })\end{array}$ & $\begin{array}{l}\text { SIGSTU23 } \\
\text { SIGSTT2 }\end{array}$ & $\begin{array}{l}126(-) \\
676,739(-)\end{array}$ & $\begin{array}{l}\text { taTAAATATct } \\
\text { TTGACC }\end{array}$ & $\begin{array}{l}\text { védekezési-, sebzés- és patogén } \\
\text { válasz. WRKY típusú transzkripciós } \\
\text { faktort köt }\end{array}$ & \\
\hline \multirow{10}{*}{$\begin{array}{l}\text { Fényválasz/ } \\
\text { cirkadián }\end{array}$} & $\begin{array}{l}\text { 3-AF1 kötő } \\
\text { hely } \\
\text { (3-AF1 binding } \\
\text { site) }\end{array}$ & SIGSTU23 & $473(-)$ & AAGAGATATTT & fényválasz elem & Lam és mtsai. 1990 \\
\hline & \multirow{3}{*}{$\begin{array}{l}\text { AE-doboz } \\
\text { (AE-box) }\end{array}$} & SIGSTU26 & $1117(+)$ & AGAAACAA & \multirow{3}{*}{ fényválaszt szabályozó rész } & \multirow{3}{*}{ Park és mtsai. 1996} \\
\hline & & SlGSTT2 & $338(-)$ & AGAAACAA & & \\
\hline & & S1GSTZ2 & $293(-)$ & AGAAACTT & & \\
\hline & \multirow[t]{6}{*}{ ACE } & SIGSTU23 & $1278(+)$ & AAAACGTTTA & \multirow[t]{6}{*}{$\begin{array}{l}\text { fényválaszban résztvevő cisz-ható } \\
\text { elem }\end{array}$} & \multirow[t]{6}{*}{$\begin{array}{l}\text { Feldbrugge és mtsai. } \\
1996\end{array}$} \\
\hline & & SIGSTU24 & $1307(-)$ & ACGTGGA & & \\
\hline & & S1GSTF5 & $60(+), 1081(+)$ & ACGTGGA & & \\
\hline & & SIDHAR2 & $399(-)$ & AAAACGTTTA & & \\
\hline & & SIDHAR5 & $70(-)$ & AAAACGTTTA & & \\
\hline & & SIGSTT2 & $223(-)$ & CTAACGTATT & & \\
\hline
\end{tabular}




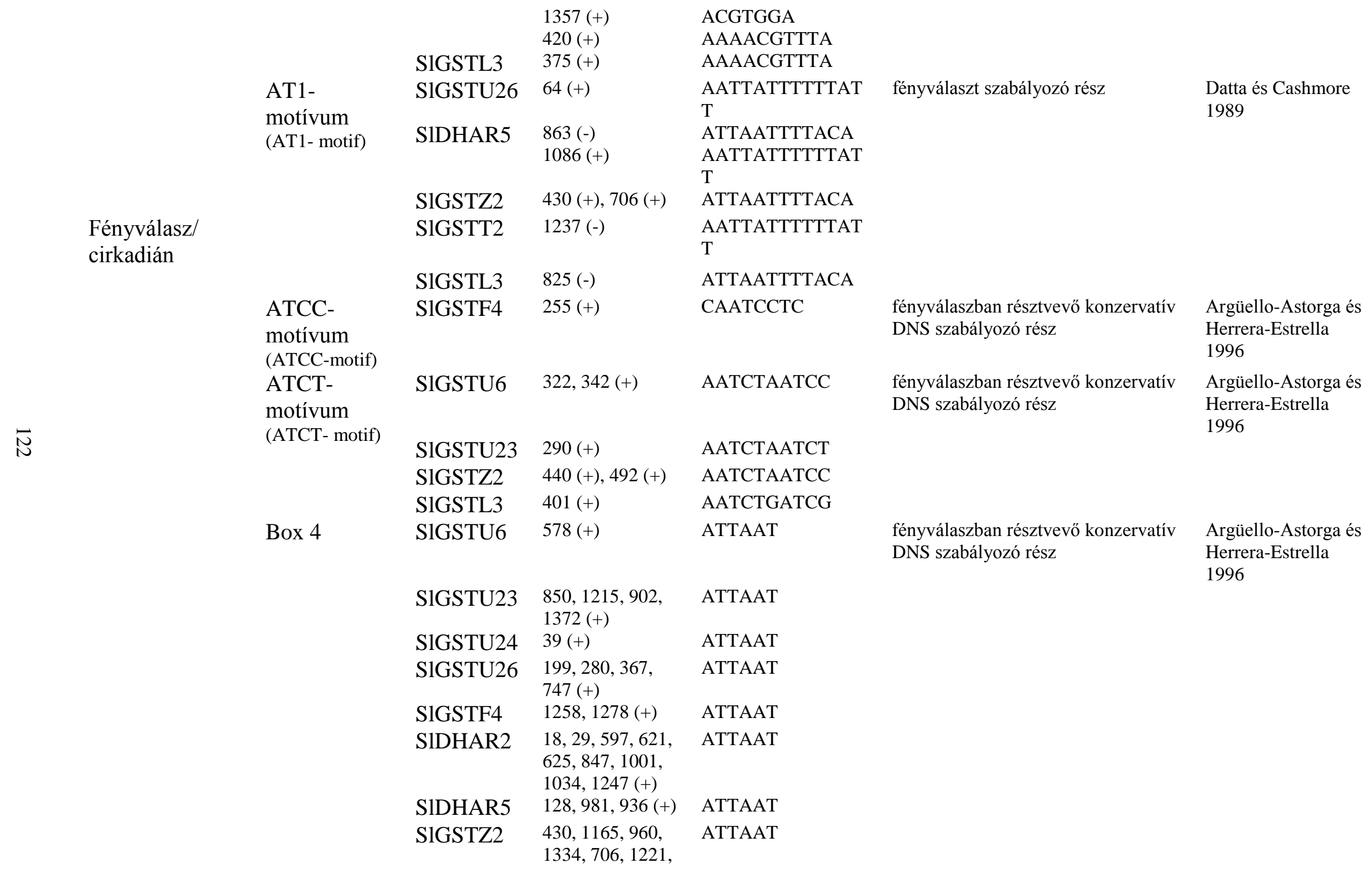




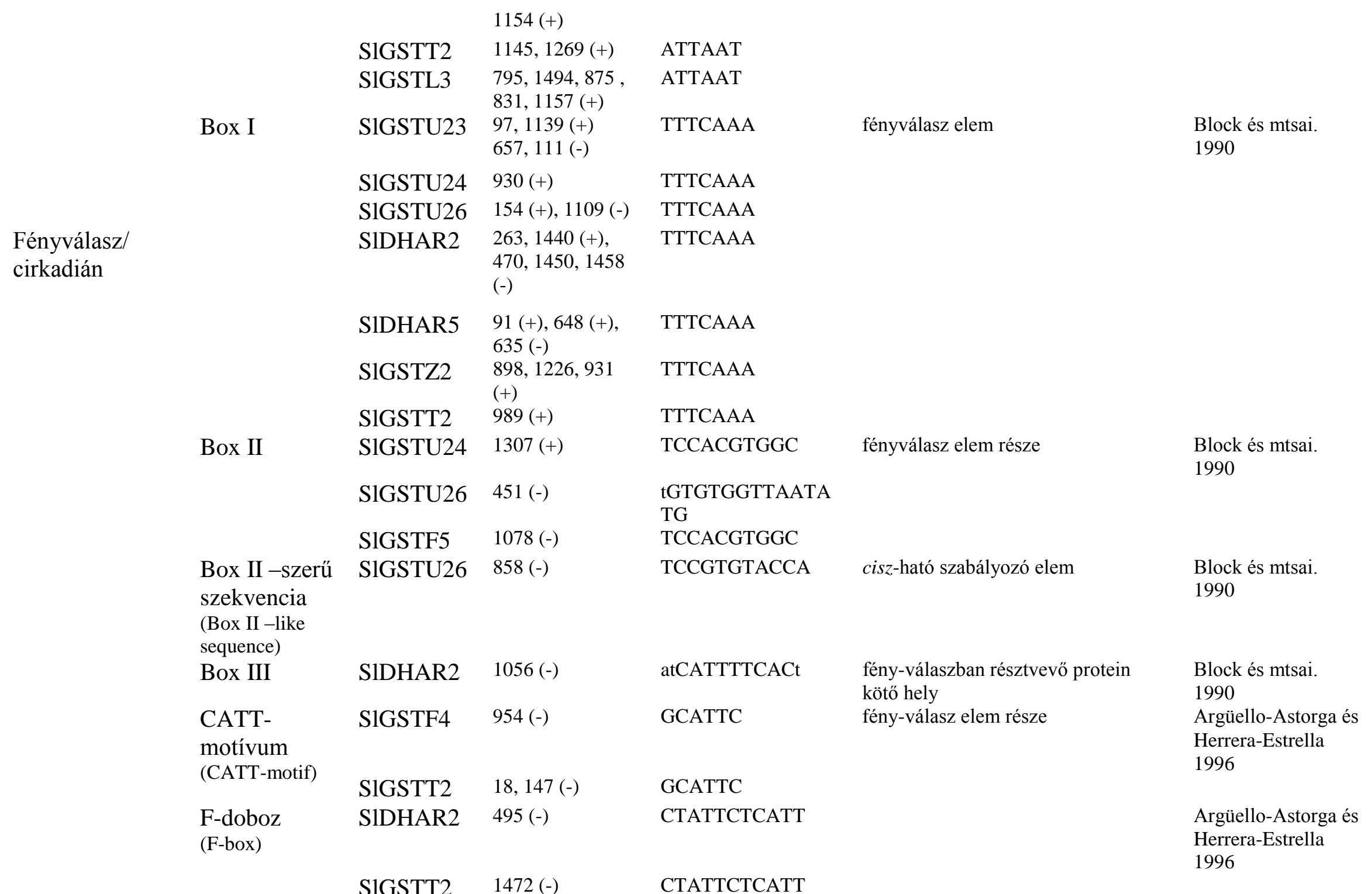


Fényválasz/

cirkadián
Donald és mtsai.

1990 fényválaszban résztvevő cisz-ható szabályozó elem

SIGSTU24 $952,1309(+) \quad$ CACGTG

$1308(-) \quad$ CACGTGG

$1307(-) \quad$ GCCACGTGGA

$59(-), 277(-) \quad$ CACGTC

CACGTG

$648(+) \quad$ CACGTT

$1126(+) \quad$ TACGTG

$1078(+) \quad$ GCCACGTGGA

SIDHAR5 $1377(-) \quad$ CACGTT

SIGSTZ2 $69(+) \quad$ CACGTT

SIGSTT2 $1356(+) \quad$ TACGTG

$1356(-) \quad$ CACGTA

$1001(-) \quad$ CACGTT

$1054(-) \quad$ CACGTA

TAAACGTG

$1054(+) \quad$ TACGTG

$1395(-) \quad$ GACATGTGGT

GATA- $\quad$ SIGSTU6 $896,1082(+) \quad$ AAGGATAAGG

motívum

(GATA-motif)

$\begin{array}{ll}\text { SIGSTF5 } & 956(+) 1410(+) \\ \text { SIGSTT2 } & 199(+) \\ & 1072(-)\end{array}$

GA-motívum SIGSTU23 $538(-)$

(GA-motif)

$\begin{array}{ll}\text { SIGSTF4 } & 881(+) \\ \text { SIDHAR5 } & 338(+) \\ \text { S1GSTU23 } & 1199(-)\end{array}$

GAG-

motívum

(GAG-motif)
AAGGATAAGG

AAGGATAAGG

AAGATAAGATT

ATAGATAA

ATAGATAA

ATAGATAA

AGAGAGT

AGAGATG

AGAGATG
Argüello-Astorga és Herrera-Estrella 1996

Argüello-Astorga és Herrera-Estrella

1996

Argüello-Astorga és Herrera-Estrella 1996 


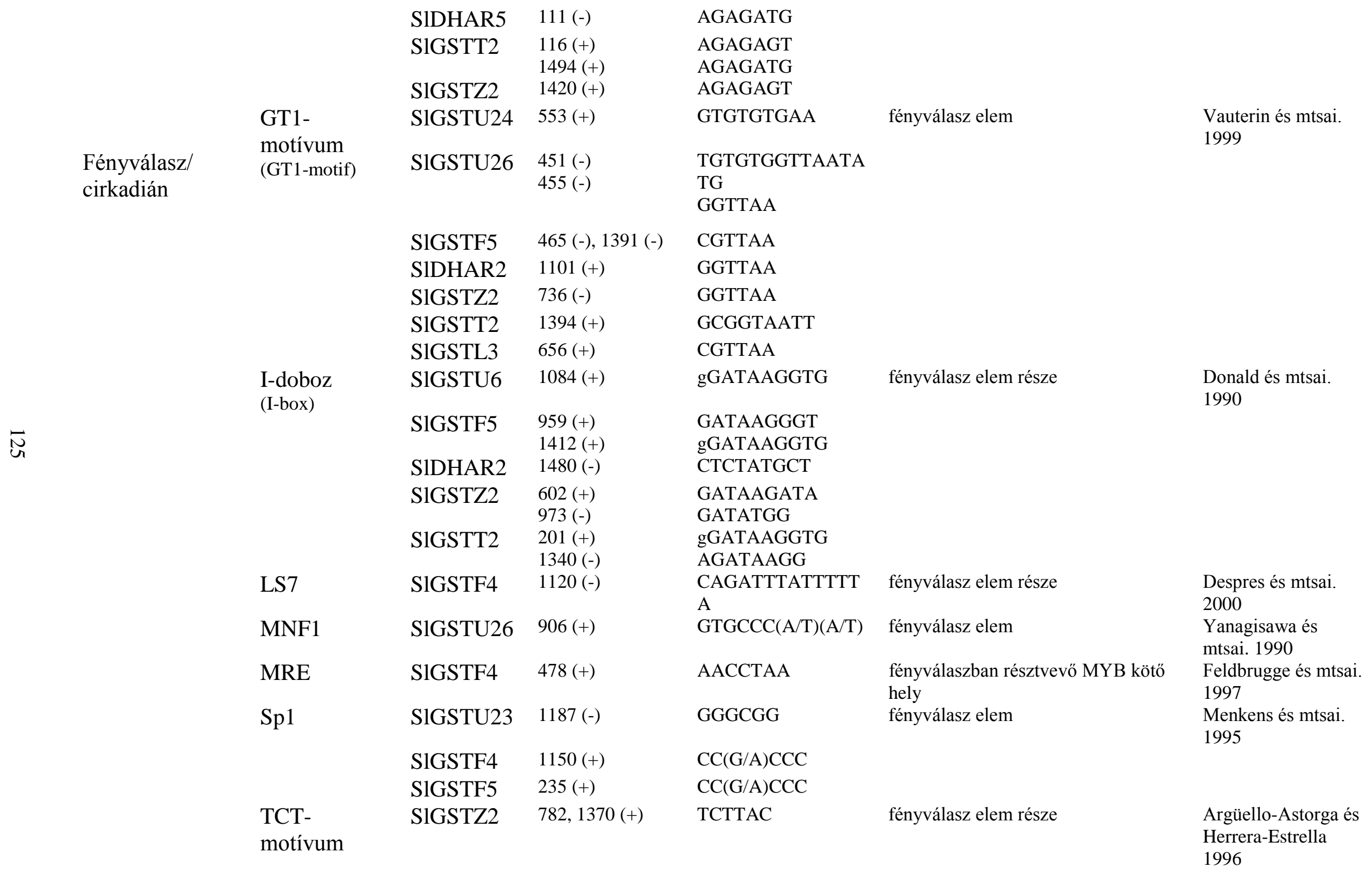




\begin{tabular}{|c|c|c|c|c|c|c|}
\hline \multirow{17}{*}{$\begin{array}{l}\text { Fényválasz/ } \\
\text { cirkadián }\end{array}$} & \multirow[t]{2}{*}{ (TCT-motif) } & SIGSTT2 & $1259(+), 482(-)$ & \multicolumn{3}{|l|}{ TCTTAC } \\
\hline & & SIGSTL3 & $1131(-)$ & \multicolumn{3}{|l|}{ TCTTAC } \\
\hline & Chs-CMA2b & SIGSTU23 & $639(-)$ & ATTGCAACTCAA & fényválasz elem része & $\begin{array}{l}\text { Argüello-Astorga és } \\
\text { Herrera-Estrella } \\
1996\end{array}$ \\
\hline & \multirow{3}{*}{$\begin{array}{l}\text { as-2-doboz } \\
\text { (as-2-box) }\end{array}$} & S1GSTF5 & $240(-)$ & GATAatGATG & \multirow{3}{*}{$\begin{array}{l}\text { hajtás specifikus expresszióban és } \\
\text { fényválaszban résztvevő elem }\end{array}$} & \multirow[t]{3}{*}{ Lam és Chua 1989} \\
\hline & & SIDHAR2 & $1059(+), 382(-)$ & GATatGATG & & \\
\hline & & SIGSTT2 & $700(-)$ & GATAatGATG & & \\
\hline & \multirow[t]{2}{*}{ Chs-CMA1a } & SIGSTU24 & $977(-)$ & TTACTTAA & fényválasz elem része & \multirow[t]{2}{*}{$\begin{array}{l}\text { Argüello-Astorga és } \\
\text { Herrera-Estrella } \\
1996\end{array}$} \\
\hline & & SIGSTU26 & $1131(-)$ & TTACTTAA & & \\
\hline & \multirow[t]{9}{*}{$\begin{array}{l}\text { cirkadián } \\
\text { (circadian) }\end{array}$} & SIGSTU6 & $110(+)$ & CAANNNNATC & \multirow[t]{9}{*}{$\begin{array}{l}\text { a cirkadián szabályozásában } \\
\text { résztvevő cisz-ható szabályozó elem }\end{array}$} & \multirow[t]{9}{*}{$\begin{array}{l}\text { Piechulla és mtsai. } \\
1998\end{array}$} \\
\hline & & SIGSTU24 & $1055(-)$ & CAAAGATATC & & \\
\hline & & SIGSTU26 & $823,1473(+)$ & CAANNNNATC & & \\
\hline & & S1GSTF4 & $206(-)$ & CAANNNNATC & & \\
\hline & & SIGSTF5 & $926(-), 1316(+)$ & CAANNNNATC & & \\
\hline & & SIDHAR2 & $411(+), 1020(-)$ & CAANNNNATC & & \\
\hline & & SIDHAR5 & $440(-), 1437(-)$ & CAANNNNATC & & \\
\hline & & SlGSTZ2 & $170,1331(+)$ & CAANNNNATC & & \\
\hline & & SlGSTT2 & $1071,1337(+)$ & CAANNNNATC & & \\
\hline
\end{tabular}

\section{A 4. és 5. mellékletekhez tartozó hivatkozások listája:}

Argüello-Astorga GR, Herrera-Estrella LR (1996) Ancestral multipartite units in light-responsive plant promoters have structural features correlating with specific phototransduction pathways. Plant Physiol 112:1151-1166.

Argüello-Astorga G, Herrera-Estrella L (1998) Evolution of light-regulated plant promoters. Annual review of plant biology 49: 525-555.

Ballas N, Wong LM, Theologis A (1993) Identification of the auxin-responsive element, AuxRE, in the primary indoleacetic acid-inducible gene, PS-IAA4/5, of pea (Pisum sativum). J Mol Biol 233:580-596.

Block A, Dangl JL, Hahlbrock K, Schulze-Lefert P (1990) Functional borders, genetic fine structure, and distance requirements of cis elements mediating light responsiveness of the parsley chalcone synthase promoter. Proc Natl Acad Sci USA 87:5387-5391. 
Bruce WB, Deng XW, Quail PH (1991) A negatively acting DNA sequence element mediates phytochrome-directed repression of phyA gene transcription. EMBO J 10:30153024.

Chen W, Chao G, Singh KB (1996) The promoter of a H2O2-inducible, Arabidopsis glutathione S-transferase gene contains closely linked OBF- and OBP1-binding sites. Plant J 10:955-966.

Daraselia ND, Tarchevskaya S, Narita JO (1996) The promoter for tomato 3-hydroxy-3-methylglutaryl coenzyme A reductase gene 2 has unusual regulatory elements that direct high-level expression. Plant Physiol 112:727-733.

Datta N, Cashmore AR (1989) Binding of a pea nuclear protein to promoters of certain photoregulated genes is modulated by phosphorylation. Plant Cell 1:1069-1077.

Després C, DeLong C, Glaze S, Liu E, Fobert PR (2000) The Arabidopsis NPR1/NIM1 protein enhances the DNA binding activity of a subgroup of the TGA family of bZIP transcription factors. Plant Cell 12:279-290.

Donald RG, Schindler U, Batschauer A, Cashmore AR (1990) The plant G box promoter sequence activates transcription in Saccharomyces cerevisiae and is bound in vitro by a yeast activity similar to GBF, the plant $\mathrm{G}$ box binding factor. EMBO J 9:1727-1735.

Du L, Chen Z (2000) Identification of genes encoding receptor-like protein kinases as possible targets of pathogen- and salicylic acid-induced WRKY DNA-binding proteins in Arabidopsis. Plant J 24:837-847.

Dunn MA, White AJ, Vural S, Hughes MA (1998) Identification of promoter elements in a low-temperature-responsive gene (blt4.9) from barley (Hordeum vulgare L.). Plant Mol Biol 38:551-564.

Feldbrugge M, Sprenger M, Hahlbrock K, Weisshaar B (1997) PcMYB1, a novel plant protein containing a DNA-binding domain with one MYB repeat, interacts in vivo with a light-regulatory promoter unit. Plant J 11: 1079-1093.

Fukuda Y, Shinshi H (1994) Characterization of a novel cis-acting element that is responsive to a fungal elicitor in the promoter of a tobacco class I chitinase gene. Plant Mol Biol 24:485-493.

Goldsbrough AP, Albrecht H, Stratford R (1993) Salicylic acid-inducible binding of a tobacco nuclear protein to a 10 bp sequence which is highly conserved amongst stressinducible genes. Plant J 3:563-571.

Gough C, Hemon P, Tronchet M, Lacomme C, Marco Y, Roby D (1995) Developmental and pathogen-induced activation of an msr gene, str 246C, from tobacco involves multiple regulatory elements. Mol Gen Genet 247:323-337.

Grandbastien MA, Berry-Lowe S, Shirley BW, Meagher RB (1986) Two soybean ribulose-1, 5-bisphosphate carboxylase small subunit genes share extensive homology even in distant flanking sequences. Plant molecular biology 7: 451-465.

Green P J, Yong MH, Cuozzo M, Kano-Murakami Y, Silverstein P, Chua NH (1988) Binding site requirements for pea nuclear protein factor GT-1 correlate with sequences required for light-dependent transcriptional activation of the rbcS-3A gene. The EMBO journal 7: 4035

Grob U, Stüber K (1987) Discrimination of phytochrome dependent light inducibie from non-light inducibie plant genes. Prediction of a common light-responsive element (LRE) in phytochrome dependent light inducibie plant genes. Nucleic acids research 15: 9957-9973.

Gurley WB, Key JL (1991) Transcriptional regulation of the heat-shock response: a plant perspective. Biochemistry 30:1-12.

Harris JC, Hrmova M, Lopato S, Langridge P (2011) Modulation of plant growth by HD-Zip class I and II transcription factors in response to environmental stimuli. New Phytol 190:823-837.

Hatton D, Sablowski R, Yung MH, Smith C, Schuch W, Bevan M (1995) Two classes of cis sequences contribute to tissue-specific expression of a PAL2 promoter in transgenic tobacco. The Plant Journal 7: 859-876.

Hobo T, Asada M, Kowyama Y, Hattori T (1999) ACGT-containing abscisic acid response element (ABRE) and coupling element 3 (CE3) are functionally equivalent. Plant J 19:679-689.

Itzhaki H, Woodson WR (1993) Characterization of an ethylene-responsive glutathione S-transferase gene cluster in carnation. Plant Mol Biol 22:43-58.

Kirsch C, Takamiya-Wik M, Schmelzer E, Hahlbrock K, Somssich IE (2000) A novel regulatory element involved in rapid activation of parsley ELI7 gene family members by fungal elicitor or pathogen infection. Mol Plant Pathol 1:243-251. 
Lam E, Chua N-H (1989) ASF-2: a factor that binds to the cauliflower mosaic virus 35S promoter and a conserved GATA motif in Cab promoters. Plant Cell 1:1147-1156.

Lam E, Kano-Murakami Y, Gilmartin P, Niner B, Chua NH (1990) A metal-dependent DNA-binding protein interacts with a constitutive element of a light-responsive promoter. Plant Cell 2:857-866

Le Gourrierec J, Li YF, Zhou DX (1999) Transcriptional activation by Arabidopsis GT-1 may be through interaction with TFIIA-TBP-TATA complex. Plant J 18:663-668.

Lefèvre A, Consoli L, Gaziola SA, Pellegrino AP, Azevedo R A, Damerval C (2002) Dissecting the Opaque-2 regulatory network using transcriptome and proteome approaches along with enzyme activity measurements. Sci Agric 59: 407-414.

Liu ZB, Ulmasov T, Shi X, Hagen G, Guilfoyle TJ (1994) Soybean GH3 promoter contains multiple auxin-inducible elements. The Plant Cell 6: 645-657.

Logemann E, Parniske M, Hahlbrock K (1995) Modes of expression and common structural features of the complete phenylalanine ammonia-lyase gene family in parsley. Proc Natl Acad Sci USA 92:5905-5909.

Lu CA, Lim EK, Yu SM (1998) Sugar response sequence in the promoter of a rice alpha-amylase gene serves as a transcriptional enhancer. J Biol Chem 273:10120-10131.

Lundin M, Nehlin JO, Ronne H (1994) Importance of a flanking AT-rich region in target site recognition by the GC box-binding zinc finger protein MIG1. Mol Cell Biol 14:1979-1985.

Menkens AE, Schindler U, Cashmore AR (1995) The G-box: a ubiquitous regulatory DNA element in plants bound by the GBF family of bZIP proteins. Trends Biochem Sci 20:506-510

Meshi T, Taoka KI, Iwabuchi M (2000) Regulation of histone gene expression during the cell cycle. Plant Mol Biol 43:643-657.

Ni M, Cui D, Gelvin SB (1996) Sequence-specific interactions of wound-inducible nuclear factors with mannopine synthase 2' promoter wound-responsive elements. Plant Mol Biol 30:77-96

Ohme-Takagi M, Shinshi H (1995) Ethylene-inducible DNA binding proteins that interact with an ethylene-responsive element. Plant Cell 7:173-182.

Park SC, Kwon HB, Shih MC (1996) Cis-acting elements essential for light regulation of the nuclear gene encoding the A subunit of chloroplast glyceraldehyde 3-phosphate dehydrogenase in Arabidopsis thaliana. Plant Physiol 112:1563-1571.

Piechulla B, Merforth N, Rudolph B (1998) Identification of tomato Lhc promoter regions necessary for circadian expression Plant Mol Biol 38:655-662.

Rouster J, Leah R, Mundy J, Cameron-Mills V (1997) Identification of a methyl jasmonate-responsive region in the promoter of a lipoxygenase 1 gene expressed in barley grain. Plant J 11:513-523.

Salinas J, Oeda K, Chua NH (1992) Two G-box-related sequences confer different expression patterns in transgenic tobacco. The Plant Cell 4: 1485-1493.

Schindler U, Terzaghi W, Beckmann H, Kadesch T, Cashmore AR (1992) DNA binding site preferences and transcriptional activation properties of the Arabidopsis transcription factor GBF1. EMBO J 11:1275-1289.

Solano R, Nieto C, Avila J, Cañas L, Diaz I, Paz-Ares J (1995) Dual DNA binding specificity of a petal epidermis-specific MYB transcription factor (MYB.Ph3) from Petunia hybrida. EMBO J 14:1773-1784.

Sutliff TD, Lanahan MB, Ho TH (1993) Gibberellin treatment stimulates nuclear factor binding to the gibberellin response complex in a barley alpha-amylase promoter. Plant Cell 5:1681-1692.

Terada R, Nakayama T, Iwabuchi M, Shimamoto K (1995) A type I element composed of the hexamer (ACGTCA) and octamer (CGCGGATC) motifs plays a ole(s) in meristematic expression of a wheat histone $\mathrm{H} 3$ gene in transgenic rice plants. Plant Mol Biol 27:17-26.

Vauterin M, Frankard V, Jacobs M (1999) The Arabidopsis thaliana dhdps gene encoding dihydrodipicolinate synthase, key enzyme of lysine biosynthesis, is expressed in a cell-specific manner. Plant Mol Biol 39:695-708.

Walker JC, Howard EA, Dennis ES, Peacock WJ (1987) Proc Natl Acad Sci (USA) 84:6624-6629.

Washida H, Wu CY, Suzuki A, Yamanouchi U, Akihama T, Harada K, Takaiwa F (1999) Identification of cis-regulatory elements required for endosperm expression of the rice storage protein glutelin gene GluB-1. Plant Mol Biol 40:1-12.

Wu C-Y, Suzuki A, Washida H, Takaiwa F (1998) The GCN4 motif in a rice glutelin gene is essential for endosperm-specific gene expression and is activated by Opaque-2 in transgenic rice plants. Plant J 14: 673-683. 
Yamaguchi-Shinozaki K, Shinozaki K (1994) A novel cis-acting element in an Arabidopsis gene is involved in responsiveness to drought, low-temperature, or high-salt stress. Plant Cell 6:251-264.

Yanagisawa S, Izui K (1990) Multiple interactions between tissue-specific nuclear proteins and the promoter of the phosphoenolpyruvate carboxylase gene for C4 photosynthesis in Zea mays. Mol Gen Genet 224:325-332.

Yu D, Chen C, Chen Z (2001) Evidence for an important role of WRKY DNA binding proteins in the regulation of NPR1 gene expression. Plant Cell 13:1527-1540.

Zahur M, Maqbool A, Irfan M, Barozai MY, Qaiser U, Rashid B, Husnain T, Riazuddin S (2009) Functional analysis of cotton small heat shock protein promoter region in response to abiotic stresses in tobacco using Agrobacterium-mediated transient assay. Mol Biol Rep 36:1915-1921. 